


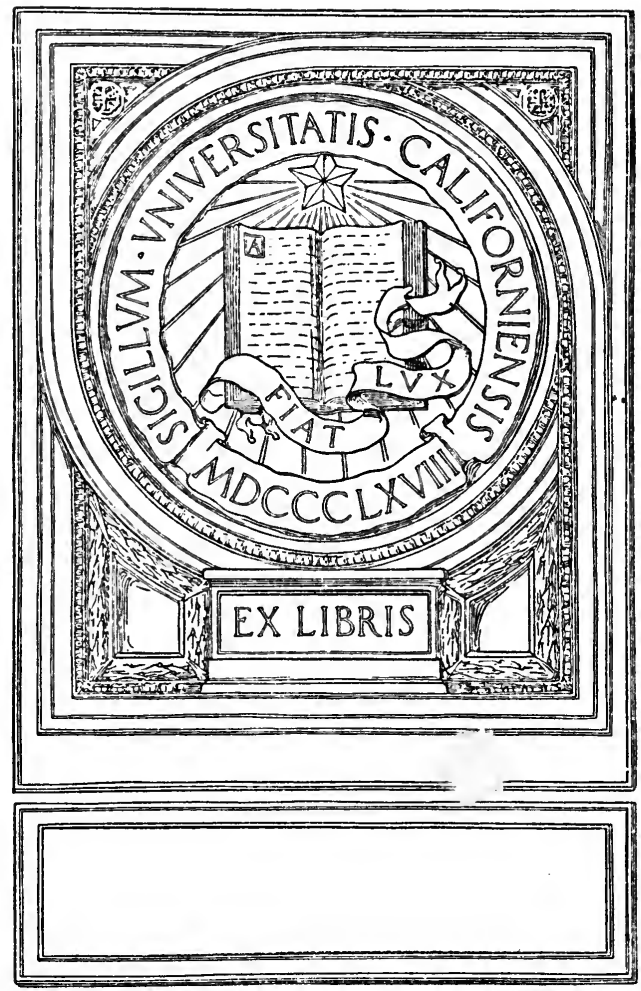






\section{.}




\section{Columbia đanibergitn Tecturę}

\section{PERMANENT INFLUENCE OF JEFFERSON}

GEORGE BLUMENTHAL FOUNDATION

1912 


\section{COLUMBIA UNIVERSITY PRESS SALES AGENTS}

New York :

LEMCKE \& BUECHNER

30-32 West 27th Street

LONDON : HENRY FROWDE

AMEn Corner, E.C.

TORONTO :

HENRY FROWDE

25 Richmond Street, W. 


\title{
THOMAS JEFFERSON
}

HIS PERMANENT INFLUENCE

ON AMERICAN INSTITUTIONS

BY

\section{JOHN SHARP WILLIAMS}

UNITED BTATEO BZNAZOR FROM MIBSISIPPI

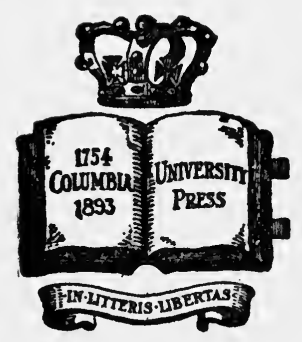

\author{
Dew 鼠ark \\ COLUMBIA UNIVERSITY PRESS \\ 1913 \\ All rights reserved
}




\section{$E 332$ \\ W45}

\section{REPLACING $2 \% 104 \%$}

$\because$ Oopyright, 2953

\section{By Coucuihais Univirattr Press}

Set up and octrotyped. Piblished April, 1913 


\section{DEDICATED}

TO

MY WIFE'S MOTHER-IN-LAW 


\section{PREFACE}

I WROTE and delivered these lectures not only in great haste, but under great pressure. At the time the promise to deliver them was made, Congress was expected to adjourn about the middle of June. It adjourned about the first of September. This subtracted two and one-half months from my time. I deemed it my duty later to devote two and one-half weeks of the time remaining to campaign field work in behalf of the election to the Presidency of one of Mr. Jefferson's successors, Governor Woodrow Wilson. The natural inference from all this is that the work may, and probably does, contain errors.

I have sought as much as possible to bring the past bodily into the present by quotations from dead actors. The reader will find a very free use of italics. It is not good taste; but the hearer was thereby spared much hearing, and the reader will be spared much reading. Italicizing the salient point of a quotation is my way of saving words of comment, which otherwise would be necessary.

No man can entirely divorce himself from his likings and dislikings. I have tried to do it; but I have for long loved world democracy and its apostles, and disliked special privilege and its beneficiaries and upholders.

There is no American about whom more has been written than Mr. Jefferson. In addition to the standvii 
ard histories of the United States and what they record concerning him, there is a distinct Jeffersonian bibliography. The list below, under the heading "Bibliography," contains articles, pamphlets, and books, especially appertaining to Mr. Jefferson, which I have read either recently, or in times past.

John Sharp Williams. 


\section{CONTENTS}

$\begin{array}{ll}\text { Chapter } & \text { Page }\end{array}$

I. INTRODUCTORY . . . . . . . . . . 1

II. Jefferson the Revolutionist

1. In America.............. 7

2. In France............... 56

III. Jefferson the Democratizer of State

InstiTUTIONS

1. A State Made Over............67 67

2. An Apostle of Local Self-Government. 96

IV. Jefferson's Influence as a Diplomat. . 107

V. Jefferson the Democratizer of FederaL

InstituTIONS

Stemming the Counter-Revolution.... 141

VI. The Influence of Jefferson as PresiDENT

1. "My Passion is Peace"............ 196

2. "An Empire for Liberty" ... . . . . . 201

3. Jeffersonian Simplicity . . . . . . . . 225

Some Minor Matters. . . . . . . . . . . 239

Summing up............... 242

VII. Jefferson's Influence on Freedom of

ReLigion in AMERICA............. 244

VIII. Jefferson's Influence on OUR EduCATional Institutions. . . . . . . . 266 BibLIOGRAPHY ................... 308

INDEX .......................... 313 



\section{PERMANENT INFLUENCE OF THOMAS JEFFERSON}

\section{ON AMERICAN INSTITUTIONS}

\section{CHAPTER I}

\section{INTRODUCTORY}

IN an article written by Andrew D. White, entitled, "Jefferson and Slavery," in the Atlantic Monthly for January, 1862, he says that "in the architecture" of our democratic republic, we find "the agency mainly of six men."

First, three men who "did most to found the Republic: and these three men are Washington, Adams and Jefferson."

"Secondly, two men who" ... " did most to build the Republic: and these two men are Jefferson and Hamilton."

"Third, three men, who, having a clear theory in their heads, and a deep conviction in their hearts ... did most to brace the Republic: and these three men are Franklin, Jefferson and Channing."

He continues:-

"So, rising above the dust raised in our old quarrels, and taking a broad view of this Democracy, we see Jefferson placed firmly in each of these groups. 


\section{$2 \cdot:$ PERMANENT INFLUENCE OF JEFFERSON}

"If we search in Jefferson's writings and in the contemporary cercids to asceitin what that power was which won him these positions, we find that it was no personal skill in cajoling friends or scaring enemies. ...

"The real secret of his power was, first of all, that Jefferson saw infinitely deeper into the principles of the rising democracy, and infinitely farther into its future working, than any other man of his time. Those who earnestly read him will often halt astounded at proofs of a foresight in him almost miraculous."

The subject prescribed for me in these lectures is the permanent influence of Thomas Jefferson on American institutions. Who can say, with assurance, what feature in a nation's institutions is permanent, until its life has been lived out to its end? To delineate the birth principles of the American confederation is easy, but to tell how far these birth principles are permanently life principles, is not so. What Solon said to Croesus applies. What features seemingly essential to our institutions at any one particular time, are really so, is a question whose answer is colored by the time at which the question is asked. If such a question had been asked during and immediately after the Revolution, when the love of freedom was at high tide, the answer would have been one thing; if after Shay's Rebellion in Massachusetts and the general anarchic condition, leading to a great and general reaction against the principles of the American Revolution, it would have been another. If asked once more, after four years of Jefferson's administration had allayed the fear of democracy and of popular rule, the reply would have been still different. Then put yourselves back in the period of 1850-60, and again to the year 1866, and yet again to 1876 , and get a different reply in each case. 
Imagine the question asked and answered during reconstruction days, and again later on after sensible men had concluded with Tourgee, who called himself "One of the Fools," that reconstruction had been "A Fool's Errand." Again how essentially different the replies would be before and after we had "gone a world-powering" in the Philippines; - before, when all were agreed that we wanted no entanglements with the old world by interference, or possession; that we desired only "friendly commerce with all and entangling alliances with none," and after, when we stood amazed to find that somehow we had sillily drifted into becoming an Asiatic power, with Asiatic territorial and political interests and anxieties.

Not knowing what all this has made pregnant in the womb of the future, which of us can assert that any particular feature of our system now deemed fundamental, characteristic, permanent, shall be so ten years from now - whether, in any particular case, "having the wolf by the ears," we shall or shall not, or can or can not, "turn him loose"? All of which concludes in this; that for the purpose of the inquiry of these lectures, that is permanent which the inquirer in his horoscoping deems permanent, and, as the wish is so much the father of the thought, it will be largely that which he wishes and prays and hopes is so.

Next, in determining the scope of our work in these lectures: what are the "institutions" of a people? Are they simply constitutional forms? If so, these United States and Mexico and the Central American republics have the same institutions; and England and Italy and Germany, all being "limited monarchies" with so-called 
"responsible parliamentary ministries," have the same institutions. Can either of these statements be true? No. Why not? Because just as a man has an outward body and an inner informing and directing soul, so a nation has a body-politic, about which we hear so much, and a soul-politic, about which we hear little, or nothing, under that name. L'Esprit des Lois - the spirit of the institution - that is, the thing vitalizing the words of constitutions and statutes - must be taken into consideration. Buckle's unfinished political novum organum - his "History of Civilization" - is only a historical analysis of the evolutionary development of the soul-politic of the peoples.

All considered, I shall then treat the subject in this full sense, and I shall exhibit the permanent, or thoughtto-be-permanent, influence of Mr. Jefferson, not only on American visible institutions, but on American vitalizing thought and practice.

But again, how can one tell a man's political influence, without knowing at least enough of his heredity and environment to explain his words, theories, and acts in the light of them?

No man can escape altogether the impress of the form and color of his time and place, nor altogether ignore the blood which courses in his veins. Yet for all this, I shall have neither time nor space. The man, Jefferson, in his lovableness of disposition, his feminine cleanness of speech and thought and life, his almost infinite versatility, his noble optimism, his worldvision, I would literally love to describe. But all that I must ruthlessly forego, save for a sidelight here and there, while correcting some errors of others. 
What was his environment? First, he was a Virginian and a planter. Secondly, he was a frontiersman, because Albemarle County, when he was growing up, was still a frontier country. The county settled very rapidly, but still, during the formative period of Thomas Jefferson's life, his environment was a frontier environment. The life he lived later was that of an independent country gentleman. Thus from both sources individuality was the first and necessary product of his life and of the lives of those about him; its chief and indispensable lesson being a reliance on one's own intellect, initiative, and resources; from which proceeded an absolute contempt for authority and precedent - merely as such.

Much has been said about Jefferson's being influenced by Rousseau's "Contrat Social." The idea of a social contract being at the base of government - a compact of the people amongst themselves - was ingrained in his thought and in the thought of all those around him, but it was not from reading. Jefferson never read Rousseau until long after his own political opinions had been formed. Indeed if he read him at all, I can find no trace of it. On the frontier people got this idea of government resting on compact because it was a fact of their lives. First one settler, then half a dozen, then a score would move into a neighborhood beyond the support of old settlements, and then naturally the neighbors would some day gather, and after they had chatted about the crops, about getting a teacher if they could, and about a place for the itinerant preacher to "hold forth" when he came, they would take up the question of the establishment of a practical local 
government; the selection of somebody before whom neighborhood differences should be argued and by whom they should be settled - by analogy of English law, a "justice of the peace" - the selection of somebody who should pursue horse thieves, or other criminals, arrest and bring them in for trial - by analogy of English law, a "constable" - the selection of somebody to correspond with the legislature to secure the organization of a new county, so that they might have a local board to lay out roads, designate ferries, etc., and so that they might have representation in the State legislative body; but preceding all, where and how and under what leadership they should meet for defence against the Indians, when needful. All of these things were done in America in each neighborhood, by a "compact" of the people with one another. This each frontiersman's son learned, with his other A B Cs, on his father's knee, as a part of the usual political experience of the American people. 


\section{CHAPTER II}

\section{JEFFERSON THE REVOLUTIONIST}

\section{IN AMERICA}

I TAKE it that the influence of our independence has permanently affected our institutions and that our revolutionary principles are the informing spirit of them; therefore, that Jefferson's acts and words as a revolutionist come within the scope of this inquiry.

Jefferson became of age in 1764. Before that, he had become attached to the cause of American freedom. Soon, nobody was more decided, none more radical, in opposition to the British policy towards the colonies than he.

In a letter to William Wirt, with his good sense and canny tact, he says: "Sensible, however, of the importance of unanimity among our constituents, although we often wished to go faster, we slackened our pace that our less ardent colleagues might keep up with us; and they, on their part, differing nothing from us in principle, quickened their gait somewhat beyond that which their prudence might of itself have advised, and thus consolidated the phalanx, which breasted the power of Britain. By this harmony of the bold with the cautious, we advanced with our constituents in undivided mass and with fewer examples" (in Virginia) "of separation than perhaps existed in any other part of the Union." 
In his biography he uses this language, concerning the origin of the committees of correspondence:-

"We were all sensible that the most urgent of all measures was that of coming to an understanding with all the other colonies to consider the British claims as a common cause to all and to produce a unity of action; and for this purpose that a committee of correspondence in each colony would be the best instrument for intercommunication: and that their first measure would probably be to propose a meeting of deputies for every colony, at some central place, who should be charged with the direction of measures which should be taken by all. I, therefore, drew up the resolutions which may be seen in Wirt, page 67."

The resolutions to which he refers designate a standing committee of intercolonial correspondence and inquiry.

There has been some contention about which colony first organized the committees of correspondence. Bancroft has it about right when he says, "Massachusetts organized a province, Virginia promoted a confederacy. Were the several committees but to come together, the world would see an American Congress."

Senator Lodge, in the History of Nations Series, Volume 23, is one of the few historians who gives due weight to the committees of correspondence and safety, as provisional governments. $\mathrm{He}$ calls them very aptly, "a system of revolutionary machinery."

Much of this committee government was secret and constitutes lost pages of our history.

The real truth is that a Union for the colonies was effected with the inauguration of the intercolonial correspondence committees. They constituted as purely a revolutionary group of bodies as did the com- 
mittees of public safety and the other committees, formed partially in imitation of them, during the French revolutionary period. It was the American committees of safety, which suggested an example for the $\mathrm{Ku}$ Klux Klan in the South later in its history - both acting with a perfect secrecy, which thus far even has never been fully unveiled. By virtue of this self-constituted authority, men threw the tea overboard in Boston harbor and persuaded, coerced, or intimidated consignees in other American ports to refuse to receive any such consignments.

A more perfectly enigmatic $\mathrm{Ku}$ Klux announcement was never made than that of John Rowe, when - the people of Boston having exhausted all peaceful and legal means to prevent the Governor from granting a pass, which would enable the ship laden with tea to clear the harbor under the guns of the castle - he asked: "Who knows how tea will mingle with salt water?" Then, Fiske recites that, "amidst profound stillness," Samuel Adams arose and said, quietly, but distinctly, "This meeting can do nothing more to save the country." This was the signal upon which the Massachusetts committees ceased by public utterance to direct the movement and when, in some agreed way, there came about the secret movement by disguised men. The "Mohawk Indians," hastening to the wharf, taking possession of the ship, unloaded its cargo into the sea.

Too much importance cannot be attached to the Revolutionary committees of correspondence; first, for making and keeping a united front between the towns in Massachusetts, upon the motion of Samuel Adams, 
and afterwards, for securing this same harmony of action and unity of purpose between the several colonies, upon the suggestion of Jefferson's resolution adopted by the band of patriots met in the Apollo Room in the Raleigh Tavern at Williamsburg. During the interregnum between recognized British authority and the newly organized American authority, these committees constituted the real government. Through them the American people learned, in nearly all of the colonies, the lesson of the capacity of the people to govern themselves directly, even without regularly constituted over-lords or governors. It is no wonder that Daniel Leonard, the great Tory and British local leader, said of these committees, "This is the foulest, subtlest, and most venomous serpent ever issued from the egg of sedition. It is the source of the rebellion. I saw the small seed when it was planted; it was a grain of mustard. I have watched the plant until it has become a tree."

The resolution to make these committees of correspondence intercolonial was, at Jefferson's request, offered in the Assembly by Dabney Carr, the friend and later the brother-in-law of Jefferson, with whom Jefferson had so often sat upon the "Little Mountain," in closest political and intellectual communion, in a sweetness of friendship seldom rivaled between men.

Now comes another meeting of the members of the House of Burgesses at the Apollo Room in the Raleigh Tavern and the formation of another association, entered into by all of them, declaring it unpatriotic to buy British East Indian tea or other commodities; that "an attack upon one of the colonies was an attack upon 
all," and directing the Corresponding Committee of the State to devise with the other committees of the other colonies a general annual congress, and at the same time calling a Virginia convention to be held at Williamsburg on August 1st, to appoint delegates to this Congress. Thus was formally conceived our Union, destined to grow and strengthen, in due process of development, until it should become indissoluble.

Massachusetts, in this crisis of her history, would probably have stood alone but for the committees of correspondence - really revolutionary committees which were keeping in elbow touch with one another from what is now Vermont down to what is now Georgia.

The action of the Government in closing the port of Boston constituted a declaration of war upon all America, although perhaps no man in the British ministry, or in the confidence of the King, so understood it.

It is wonderful how everything goes back to this Apollo Room in the Raleigh Tavern, where Jefferson was one of the ruling spirits. For example, the movement towards a Continental Congress came first from New York. Coming from that State, only partially loyal to the American cause - perhaps not at that time loyal by a majority vote - it would have died still-born, had it not been taken up by the members of the Legislature of Virginia - prorogued and adjourned - but still sitting in solemn voluntary session - in the Raleigh Tavern.

It was on the 14th day of May, 1776, that the selfreconstituted Legislature of Virginia unanimously voted these instructions to its delegates: "To propose 


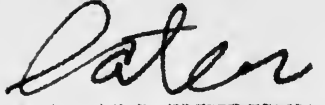

12 PERMANENT INFLUENCE OF JEFFERSON

to that respectable body" (meaning by that respectable body, the Continental Congress) "to declare the United Colonies free and independent States," and to "give the assent of this Colony to measures to form foreign alliances and a confederation, provided the power of forming government for the internal of each colony be left to the colonial legislatures." Here is the germ of our dual system of government - federal in foreign and inter-state matters, state in domestic affairs. In all your study of American history, keep this italicized proviso in your minds. It will explain much.

Revolutionary intimidation, it must be confessed, reigned foot-loose throughout America. The bold, patriotic and liberty-loving were not everywhere in a majority. The conditions were such, as Fiske says, that "neither councillors, nor judges, neither sheriffs nor jurymen, could be found to serve under the royal commission" to "execute the Regulating Act in Massachusetts." He further adds that for nine months this state of seeming anarchy continued, and that "yet the affairs of every-day life had gone on without friction or disturbance."

This too recalls the condition of affairs in the South in '74 and '75, when, first in one place and then in another, all carpet-bag authority had been intimidated into flight or quiescence, and yet afterwards peace and law and order reigned. Both conditions, as well as what happened in the early history of California, are high tributes to the capacity of the American people for self-government.

The instructions of Albemarle County to Mr. Thomas 
Jefferson and Mr. John Walker, their two members of the House of Burgesses and their two deputies to the convention, are worth regarding, especially as from the style and the surroundings they were evidently written by Mr. Jefferson. They are as follows:-

"Resolved, That the several inhabitants of the several States of British America are subject to the laws which they adopted at their first settlement, and to such others as have been since made by their respective Legislatures, duly constituted and appointed with their own consent. That no other Legislature whatever can rightly exercise authority over them, and that these privileges they hold as common rights of mankind, confirmed by political constitutions they have respectfully assumed, and also by several charters of compact from the Crown."

Notice he goes back to the "common rights of mankind," which are "confirmed" - not created by charters and "political constitutions."

The language, "these privileges they hold as common rights of mankind," is, so far as I can discover, the first basing of the American cause upon "the rights of man," rather than upon the inherited legal rights of Englishmen. This was to grow into an assertion of the inherent right of self-government vested in every community, and by logical consequence, into the claim of right upon the part of any community to throw off any government, which, in its opinion, had ceased to subserve the purpose of all government, to wit: securing and maintaining the happiness and the liberties of those governed. Jefferson in his "Memoir" says, that these were his views from the very first dawn of the dispute, but that he had then "never been able to get anyone to agree with him except Mr. Wythe." 


\section{PERMANENT INFLUENCE OF JEFFERSON}

Patrick Henry, the controlling genius in Hanover County, and probably the dictator of its resolutions, did not go so far. We find these resolutions asserting only "the privileges and immunities of their fellowsubjects in England," etc.

The resolutions from Fairfax County, where George Washington presided over the meeting, used language not so strong as that of Hanover.

The Virginia Convention met at the prescribed time. Jefferson was prevented by illness from attending. $\mathrm{He}$ had prepared, to be offered to the Convention, a draft of instructions to the Virginia members of Congress. He had forwarded a copy to Peyton Randolph and one to Henry. The fate of these resolutions we will give in Mr. Jefferson's own language:-

"They were written in haste, with some uncertainties and inaccuracies about historical facts, which I neglected at the moment, because I thought they could be readily corrected at the convention. ... Peyton Randolph informed the convention that he had received such a paper from a member, prevented by sickness from offering it in his place, and he laid it on the table for perusal. It was read generally by the members, approved by many, though thought too bold for the present state of things; but they printed it in pamphlet form, under the title of 'A Summary View of the Rights of British America.' It found its way to England and was taken up by the opposition, interpolated a little by Mr. Burke, so as to make it answer opposition purposes" (in England) "and in that form ran rapidly through several editions. ... I I was informed afterwards by Peyton Randolph, that it had procured me the honor of having my name inserted in a long list of proscriptions, enrolled in a bill of attainder, which was commenced in one of the Houses of Parliament, but was suppressed in embryo by the hasty step of events, which warned them to be a little cautious. . . . Tamer sentiments were preferred, and, I believe, wisely preferred; the leap I proposed being too long, as yet, for the mass of our citizens. The distance 
between these and the instructions actually adopted, is of some curiosity, however, and it shows the inequality of pace with which we moved, and the prudence required to keep front and rear together. My creed had been formed on unsheathing the sword at Lexington." (Lexington here is a lapsus linguae, or "plumae"; Boston is meant.)

This "Summary View of the Rights of British America" became the mine into which many delved for ideas and phrases in presenting the American side of the dispute.

The Virginia State "Convention" is worthy of note in this; that it is, as far as I know, the first of those peculiarly characteristic American institutions. A "Convention" with us is considered superior to an ordinary representative assembly; so much so, that a state convention can adopt a new constitution, without even referring it back to the people for their approval, as has been done in my State two or three times. It is looked upon as "the body of the people representatively assembled" and possesses full powers for state purposes, as a national convention would have for the purpose of completely altering the Constitution of the United States.

Jefferson's argument in the "Summary View" is based very strongly upon the assertion of the right of expatriation. Hence his constant insistence through life on that right. It was, according to his view, at the very root of our contention in the Revolution. The right of expatriation was not then admitted by any nation of the earth. It is not admitted by Russia at all, nor fully by Prussia, nor Austria, to this good day, and was denied by Great Britain up to and even after the War of 1812 . It has not been very long since we abrogated 
a treaty with Russia, growing out of differences between that Government and ours, based upon antagonistic views with regard to the doctrine of indefeasible allegiance. The "Summary View," however, takes the position that the American colonies expatriated themselves as fully as did the Angles and the Saxons from their old country, when they settled in England, and that except for their voluntary adhesion to the same crown, the independence between the two countries would have been as complete, as that between England and the old home of the race.

Jefferson had gone back to the Greek Republican conception of the status of colonies.

The assertion is made that Great Britain had rendered no assistance to the colonists until after they had established themselves on a firm and permanent footing, and had, therefore, become valuable as customers to the mother country; that we had submitted to trade regulations in our own interest, as long as they were not too restrictive to our own rights and were advantageous to the mother country, but that these had now become unbearable and too oppressive to be further permitted.

From the same instrument, I shall quote another sentence characteristically Jeffersonian, because it is a forerunner of what will later appear in the Declaration of Independence:

"Scarcely have our minds been able to emerge from the astonishment into which one stroke of Parliamentary thunder has involved us, before another, more heavy and more alarming, is fallen on us. Single acts of tyranny may be ascribed to the accidental opinion of a day; but a series of oppressions, begun at a distinguished period 
and pursued unalterably through every change of ministers, too plainly prove a deliberate, systematical plan of reducing us to slavery."

It is not too much to say that the "Summary View of the Rights of British America" contained most of the essential ideas of the Declaration of Independence. It antedated that document by nearly two years; it complained of the same wrongs and set forth the same inherent and natural rights, and, in some respects, was more advanced in its views than the Declaration itself.

It was scarcely a subject of wonder that it led to Mr. Jefferson's being placed upon the proscribed list. Here, as elsewhere, the student of Jefferson's life will find him always in advance, even of the progressive wing of the party with which he is coöperating, and will also find an illustration of his readiness to yield and concede non-essentials in order that all might move along together.

One thing is most remarkable; the "Summary View" goes out of its way to refer justifyingly to the execution of Charles I. This was done in a paper proposed to be adopted by a Virginia convention, where men sat whose forefathers had resisted in the cause of the Stuart the utmost power of Oliver Cromwell, until, indeed, a formal treaty had been entered into between the great Lord Protector and the Old Dominion. In that body sat men, whose forefathers had been killed in the King's service, or had left England for Virginia rather than submit to the rule of the "Commonwealth."

A distinguished Ex-President speaks of Mr. Jefferson as being "timid" and "vacillating!" He was more nearly rash. 
The reader of the "Summary View" will note the ground upon which Jefferson places his protest against closing the port of Boston. It is the punishment of the many innocent for the acts of the few guilty.

In this connection, it might be recalled that certain people in a Southern town, having signed a petition to a negro postmistress requesting her resignation, which was regarded by the Administration as a species of "intimidation," the post office was closed, by order of an American President, and all of the people in the town and adjacent territory put to the inconvenience and expense of getting their mail from a place a dozen miles or more away. The Federal Court was open, with Federal judge, marshal, grand juries and petty juries, and the federal law could have been vindicated by an exercise of the ordinary powers of the court. Even a little instance like this shows the importance of keeping general principles of justice and right government always in view, and illustrates the truth of the timehonored maxim that "eternal vigilance is the price of liberty."

Nobody in Virginia, or South Carolina, or New York, would have objected, or would have had any right to object, to the punishment by law of the men who unlawfully seized and threw the tea into the harbor, but the high-handed punishment of the whole people showed an absolute disregard of accepted rules of civilized government, and "an intention not to punish an act, but an opinion." Still more tyrannical was the act of Parliament providing for the trial in England for certain classes of offenders. The plea in both cases and in the Southern post office case, that "the 
juries will not convict," is one to which tyrants resort, but one which ought never to be entertained in a free country.

It is only needful to add that the ideas expressed in the "Summary View," in the latter part of which Jefferson adjures George III, "no longer to persevere in sacrificing the rights of one part of the empire to the inordinate desires of another, but to deal out to all equal and impartial right," and to "let no act be passed by one legislature which may infringe upon the rights and liberties of another," and reminds him that, "this is the important post in which fortune has placed you, holding the balance of a great, if a well-poised empire," now constitutes the principle underlying the practice of the British empire towards her white colonies. Canada, Australia, New Zealand, and the mother country are virtually held together only by the common kingship - the sole tie binding Virginia and England under Jefferson's theory. Each has its own admittedly independent legislative assembly, and the Parliament of Great Britain would no more think of legislating for Canada, in any really Canadian concern, than the Canadian Parliament would think of legislating for England or Wales. If the British Empire has become "a well-poised empire," with reciprocal advantages for all its connections, it has been because of the wise adoption of this salutary rule.

Again Jefferson says to the King: "Accept of every commercial preference it is within our power to give," etc. Today, if Canada, or any of the British colonies give trade preferences to Great Britain, it is because they choose to give them, and not because of any ac- 
knowledged right of the mother country to demand them, under the guise of regulating commerce. Thus this doctrine, which was thought to be too bold for adoption by the Virginia convention, even in the throes of a great revolution, is become the accepted doctrine of the "great" and "well-poised" empire, to whose king the propositions were addressed in reproof.

Jefferson was elected Chairman of the Albemarle County Committee of Safety - such being, I presume, the confidence of the boys, who had been raised with him, in his "timidity" and "vacillation!"

Girardin, in his "History of Virginia," page 6, says, that "the operations of these committees not being definite, were almost unlimited." Perhaps from them and Jefferson's recollection of them, the revolutionary committee system in France may have had its birth, though, of course, no man, who had experienced committee government among the free, politically-trained, and comparatively equal and well-to-do inhabitants of America, could have foreseen its destructiveness and folly in France.

Girardin says of these committees that they examined the books of merchants to see if they imported the articles which were forbidden, or sold at higher prices than they should; that they examined all suspected persons, disarmed, fined, and punished them, and that, when necessary, they enlisted trained officers and armed independent companies - (the "minute men" of whom you read) - in each county, and that from their decision there was no appeal. Randall says that "it would be difficult to say where the power of these local tribunals stopped, except that they did not 
exercise the death penalty and the power to confiscate estates, which last powers were retained by the conventions of the colonies."

Jefferson was, throughout his life, radical in ends and conservative in means. It is not surprising, then, to find that the Committee of Safety in Albemarle County was less proscriptive in its conduct - more cautious and wise - than almost anywhere else.

Then Mr. Jefferson was chosen a member of the Continental Congress.

Meanwhile, Lord North's "Conciliatory Proposal," as it was called, had been received in the colonies and it was necessary that Virginia, among other colonies, should make reply. Jefferson says:-

"The tenor of this proposition, being generally known, as having been addressed to all the Governors, Peyton Randolph was anxious that the answer of our Assembly, likely to be the first, should harmonize with what he knew to be the sentiments and wishes of the body he had recently left. He feared that Mr. Nicholas, whose mind was not yet up to the mark of the times, would undertake the answer, and, therefore, pressed me to prepare it. I did so, and with his aid, carried it through the House, with long and doubtful scruples from Mr. Nicholas and James Mercer, and a dash of cold water on it here and there, enfeebling it somewhat, but finally with unanimity, or a vote approaching it."

The salient points of this document were, that the British Parliament, not being an American legislative assembly, had no right to interfere with civil government in any of the colonies; that Lord North's proposition involved the idea that the colonies, "in order to secure exemption from an unjust tax, must saddle themselves with a self-inflicted perpetual tax," "adequate to the expectations and subject to the disposal 
of Parliament alone;" that "many of the American grievances previously stated were taken no note of in the proposal, because the ministry were then making disposition to invade the colonies;" that the ministry did not propose to lay open to them "a free trade with all the world;" and significantly that the proposition made to Virginia involved the interest of all the other colonies, and that all the colonies were represented in a general congress, and that "no partial obligation should produce a disunion from the common cause;" that Virginia considered herself in honor bound to "share what ever general fate might betide her sister colonies." Thus Virginia acknowledged and emphasized our Union.

The conclusion was the expression of a final determination to leave the question to the disposition of the general Congress, before whom the House of Burgesses would lay the papers. Then speaking for Virginia alone occurs this language:

"For ourselves, we have exhausted every mode of application, which our invention could suggest as proper and promising. We have decently remonstrated with Parliament - they have added new injuries to the old; we have wearied our king with supplications - he has not dared to answer us; we have appealed to the native honor and justice of the British nation - their efforts in our behalf have hitherto been ineffectual; what then remains to be done? That we commit our injuries to the even-handed justice of that Being, who doeth no wrong, earnestly beseeching Him to illuminate the councils and prosper the endeavors of those to whom America hath confided her hopes, that through their wise discretion we may again see reunited the blessings of liberty, prosperity and harmony with Great Britain."

A similar arraignment of the justice of the British people, in the original draft of the Declaration of 
Independence, was stricken out by the Continental Congress!

Jefferson carried Virginia's reply to Lord North with him to the Congress at Philadelphia, where we now take up the thread of our story.

John Adams afterwards said that, although Jefferson was not a public speaker, owing to his voice (or rather lack of voice), he (Adams) found that, "though a silent member of Congress, he was so prompt, frank, explicit and decisive upon committees and in conversation (not even Samuel Adams was more so), that he soon seized upon my heart."

This language of a contemporary is recommended to the perusal of so-called historians, rough-riding over facts. He never "vacillated," nor was "timid," nor showed "a sluggish mind" in "the times that tried men's souls," nor in the face of any crisis at any time, though in non-essentials he was always the most yielding of all sweet natures.

Virginia's answer to Lord North's "Conciliatory Proposal," as drawn by Jefferson, "met the views of the more advanced members of the Whig party in Congress," and "the importance of it was fully measured by all," because, if adopted, it would have the effect of "closing the door to argument with the mother country." It was adopted by Congress. It left us two alternatives; a successful redress of grievances by arms on the one hand, or subjugation on the other.

Five days after he took his seat in Congress, Jefferson was placed on an existing committee to make a statement, or declaration, of "the causes of the colonies taking up arms." The committee had already made a 
report, of which the Congress had disapproved; therefore the two new members - Mr. Jefferson of Virginia, and Mr. Dickinson of Pennsylvania. Jefferson's pen was again called into requisition. He prepared a draft for the declaration, but it was too strong for $\mathrm{Mr}$. Dickinson, who still retained the hope of reconciliation. Jefferson says that Dickinson was "so honest a man and so able," that he "was requested to take the paper and put it into a form that he could approve;" that Dickinson did it, preserving of Jefferson's declaration "only the last four paragraphs and a half;" that the committee approved and reported the declaration, as thus framed, to Congress, which accepted it.

Mr. Dickinson belonged to that class of people to which Alexander Stephens belonged in the South, at the outbreak of the War between the States; men who wanted to hang back, who saw the brink before them, who feared the jump, but who were so loyal and true to their neighbors and friends and states, that when the latter once took a stand, they moved up, in shoulder to shoulder touch, to stand, until success, or defeat, or death should come.

There was about Jefferson no vanity of authorship. This was an illustration of it. It was years after Dickinson's "Address on the Cause of Taking up Arms" had been welcomed with the huzzahs of the American people, before anybody, outside of Congress, knew that Jefferson had had any hand in it - indeed, it was only after Jefferson's death that his original draft was found, and the knowledge became general that the last four and a half paragraphs of Dickinson's paper were Jefferson's. This address owed its popularity chiefly to the last four and a half paragraphs. 
I will now quote some extracts from Jefferson's paragraphs. Remember, it was an address to be read at public gatherings and to our armies in the field, and it was written with a view to the uses which it should serve. I do not know whether you will agree with me or not, but I deem these to be noble words, eloquently and worthily clothing manly thought:-

"We are reduced to the alternative of choosing an unconditional submission to the tyranny of irritable ministers, or resistance by force. The latter is our choice. We have counted the cost of this contest, and find nothing so dreadful as voluntary slavery. Honor, justice, and humanity, forbid us tamely to surrender that freedom which we received from our gallant ancestors, and which our innocent posterity have a right to receive from us. We cannot endure the infamy of resigning succeeding generations to the wretchedness, which inevitably awaits them, if we basely entail hereditary bondage upon them. Our cause is just. Our union is perfect - our internal resources are great, and, if necessary, foreign assistance is undoubtedly attainable. . . . With hearts fortified with these animating reflections, we most solemnly, before God and the world, declare, that, exerting the utmost energy of those powers which our beneficent Creator hath graciously bestowed upon us, the arms we have been compelled by our enemies to assume, we will, in defiance of every hazard, with unabated firmness and perseverance, employ for the preservation of our liberties; being with one mind resolved to die free men, rather than to live as slaves.

"Lest this declaration shall disquiet the minds of our friends and fellow subjects in any part of the empire, we assure them, that we mean not to dissolve that union which has so long and so happily subsisted between us, and which we sincerely wish to see restored. Necessity has not yet driven us into that desperate measure, or induced us to excite any other nation to war against them. . . We fight not for glory or for conquest. . . .

"In our own native land, in defence of the freedom that is our birthright, and which we ever enjoyed until the late violation of it; for the protection of our property, acquired solely by the honest in- 
dustry of our forefathers and ourselves, and against violence actually offered, we have taken up arms. We shall lay them down when hostility shall cease on the part of our aggressors and all danger of their being renewed shall be removed, and not before."

These resolutions were submitted to the Continental Congress on the 6th day of July, 1775, a year, lacking two days, prior to the Declaration of Independence. Sixteen days later, Congress selected as usual by ballot - the members selected taking priority in accordance with the number of votes received - a committee to consider and report on Lord North's "Conciliatory Proposal." Jefferson was second on the committee, the septuagenarian Benjamin Franklin alone receiving a higher vote. Mr. Jefferson was selected by the committee when it met, to draw up this paper. In his Memoir he says: "The answer of the Virginia Assembly on that subject having been approved, I was requested by the committee to prepare this report, which will account for the similarity of features in the two documents." Yes, they were nearly alike, but the instrument had broadened and the words "walked statelier," to suit the new and broader stage.

John T. Morse, in his "Thomas Jefferson," says of this paper as it passed the Virginia Convention, being substantially as it passed Congress later:-

"This was laying the axe at the very root of the tree with tolerable force; and more blows of the same sort followed.

"These were revolutionary words, and fell short by ever so little of that direct declaration of independence which they anticipated by less than two years. They would have cost Jefferson his head had it been less inconvenient to bring him to Westminster 
Hall, and even that inconvenience would probably have been overcome had forcible opposition been a little longer deferred in the colonies."

That Jefferson had not surrendered all hope of a satisfactory reconciliation with Great Britain, although he had gone much further towards planting himself upon the solid ground of independency than threefourths of his colleagues, is witnessed by the language contained in a letter written by him to John Randolph (not he of Roanoke - "John The Eccentric" - of course, but an earlier and a nobler one), who, finding it impossible to take up arms against the King, and unthinkable to take up arms against his neighbors, had sacrificed everything he had in Virginia and gone to England - not to fight with her, but to live in peace - one of those noble souls willing and able to stand and suffer all things alone, rather than take a choice between two wrongs, as he saw them. That his conduct was mistaken, few can doubt. That it was noble and unselfish, his own sacrifices witness. Jefferson wrote to him a letter from Monticello, dated August 25, 1775. In this case, as in all others, Jefferson never permits his hatred of a course to alienate him from a friend. The letter to John Randolph, uncompromisingly, even aggressively patriotic, in every line of it, was also uncompromisingly friendly to the recipient of it.

I want you to read that letter. If you are both manly and kindly, it will do you good. It aims to get Randolph to use his influence to bring about in the mother country a juster appreciation of the rights and of the earnestness of the colonies. 
Later, on November 25th, he wrote to the same Mr. Randolph, then in England, another letter, from which it appears that he had meantime gone several steps further towards irrevocable independency. In part it reads: -

"In the early part of this contest, our petitions told him that from our King there was but one appeal. The admonition was despised, and that appeal forced on us. To undo his empire, he has but one truth more to learn; that after colonies have drawn the sword, there is but one step more they can take. That step is now pressed upon us by the measures adopted, as if they were afraid we would not take it. Believe me, dear sir, there is not in the British empire, a man who more cordially loves a union with Great Britain, than I do. But by the God that made me, I will cease to exist before I yield to a connection on such terms as the British Parliament proposes; and in this, I think I speak the sentiments of America. We want neither inducement nor power, to declare and assert a separation. It is will, alone, which is wanting, and that is growing apace under the fostering hand of our King."

Fiske adds as a comment upon this: "Observe the historical accuracy of this wording. It was not a question of throwing off a yoke, but of refusing to yield to a connection on newfangled and degrading terms."

Jefferson, in his "Notes on Virginia," says, "It is well known that in July, 1775, a separation from Great Britain and establishment of republican government had never yet entered into any person's mind. If any period can be fixed, when the idea of independence became any more than a thought, or ceased to become a mere thought and became in some lines a policy, it probably would be the date upon which the communication from Richard Penn and Arthur Lee, who 
had been sent to Great Britain to deliver the second petition to the King, was received and read in Congress."

This communication from Penn and Lee stated that the reply of the King was, that "no answer would be given." This high-handed and contemptuous ignoring of a respectfully, even humbly, worded address, caused anger and resulted in the conclusion on the part of the bolder natures, that the step forward to independence must at once be taken.

Jefferson had long considered the possibility, as his pregnant "as yets" and very many other phrases demonstrate. But there is always a step, long or short, between considering a thing as a dernier resort, and embracing it as a present measure of redress.

Mr. Adams is simply mistaken when, writing in his old age, he says that he had been determined "from the first assembling of the Congress in 1775 upon independence," and that "this was no secret in or out of Congress." Old men are apt to get dates wrong. Adams and Jefferson both did it, when writing in their old age about things which occurred in their early manhood. Adams' letters, like those of Jefferson, which I have quoted, show that, except in so far as it was a possibility to be contemplated, if the worst came to the worst, independence was not yet urged by any. John Jay's and Benjamin Franklin's memories accord with Jefferson's.

The truth is that Americans, as a rule, were almost as unwilling to tear themselves from governmental connection with the British Isles, as were the "Jackson Democrats" and the "Old Line Whigs" in the South, 
at the beginning of The War between the States to "dissolve the bonds that bound" them to the Union, and in each case there was an idea of fighting, even if bloodshed came, "under the old flag," as abused subjects, or citizens, of the old government, rather than as citizens of an independent country.

Indeed, on November 29, 1775, the date of Jefferson's second letter to Randolph, Congress itself used this language; "that they should rely to the last on heaven and their own virtues for security against the abusive system pressed by the administration for the ruin of America," and that "there is nothing more ardently desired by North America than a lasting union with Great Britain, on terms of justice and equal liberty."

As late as December, 1775, the Continental Congress speaks of the British constitution as "our best inheritance."

Remember all this, when we come to discuss the American Counter-Revolution, in the lecture, "Jefferson the Democratizer of National Administration."

What Adams in his old age wrote about the circumstances attending the writing of the Declaration of Independence was equally inaccurate.

On August 30,1823, what Adams wrote having been printed, Mr. Jefferson made the following correction: -

"Mr. Adams' memory has led him into unquestionable error. At the age of eighty-eight, and forty-seven years after the transactions of independence, this is not wonderful. Nor should I, at the age of eighty, on the small advantage of that difference only, venture to oppose my memory to his, were it not supported by written notes taken by myself at the moment and on the spot. . . . Now these details are quite incorrect. The Committee of Five met; no such thing as a subcommittee was proposed, but they unani- 
mously pressed on myself alone to undertake the draft. I consented; I drew it; but before I reported it to the committee, I communicated it separately to Doctor Franklin and Mr. Adams, requesting their corrections, because they were the two members of whose judgments and amendments I wished most to have the benefit, before presenting it to the Committee; and you have seen the original paper now in my hands, with the corrections of Doctor Franklin and Mr. Adams interlined in their own handwritings. Their alterations were two or three only, and merely verbal. I then wrote a fair copy, reported it to the Committee, and from them, unaltered, to Congress. This personal communication and consultation with $\mathrm{Mr}$. Adams he has misremembered into the actings of a sub-committee."

Jefferson gratefully says that Adams was "the colossus of that debate."

From November, 1775, on, the number of those, who had decided upon independence, as the only satisfactory issue out of the contest, increased. It is wonderful even then how few of our people based their contention upon anything more than English statutes and customs and traditions - all of doubtful application. Few of them, except Jefferson, went as far as Johan Derk van Capellen went in his reply to George III, who, having asked the states of Overyssel for troops, was answered that Johan Derk thought, "the Americans worthy of every man's esteem," and looked upon them as "a brave people, defending in a becoming, manly, and religious manner those rights, which, as men, they derived from God; not from the legislature of Great Britain."

Thus, though Mr. Jefferson had a hard time at home in keeping his phrases "natural rights," and "inherent rights," and "rights derived from God," and all that, from being stricken out of his public 
papers as too rhetorical, or too abstract, old Johan Derk van Capellen, away over in Overyssel, had the American idea and expressed it.

On May 15, 1776, Virginia, where the King's name had been already legislated out of the prayer book and the Continental Congress substituted for it, adopted her resolutions instructing her representatives in the Continental Congress to take the initiative and to move independence. Moreover, the House of Burgesses passed a "declaration of rights," and ordered "a plan of government" to be prepared; in other words, a written constitution for Virginia. Significantly American this written Constitution! The thing had gone out of use since the times of the Greek Republics.

Mr. Jefferson's absence early in May from Philadelphia and his stay in Virginia for nearly four months were due to a desire to prepare the public mind in Virginia for this step. He remained in Virginia nearly four months, at any rate, and then immediately upon his return to Congress, was made chairman of the committee to consider and report a declaration of independence.

Richard Henry Lee, on Friday, June 7th, being "Dean of the Virginia Delegation in Congress," called up the resolutions, which the Virginia House of Burgesses had instructed the delegates from Virginia to present. Their consideration was postponed until the next day. They were debated in committee of the whole, throughout Saturday and the succeeding Monday, and then this resolution was passed:

"Resolved, That the consideration of the first resolution be postponed to Monday, the first of July next; and in the meanwhile, in order that no time be lost, in case the Congress agree thereto, 
that a committee be appointed to prepare a declaration to the effect of the first resolution, which is in these words: that these colonies are, and of right ought to be, free and independent states; that they are absolved from all allegiance to the British Crown, and that all political connection between them and the state of Great Britain is, and ought to be, totally dissolved."

The delay was because Congress, like the old Virginia House of Burgesses, was trying "to keep front and rear together."

It was on the 11th of June, that the committee for preparing and reporting a declaration of independence, consisting of five members, was chosen, as usual, by ballot (the members, by the parliamentary usage of the Continental Congress, taking their places upon the committee list according to the number of votes cast for them, the one receiving the highest vote being ipso facto chairman). The committee thus selected consisted of Thomas Jefferson, first, John Adams, second, Benjamin Franklin, third, Roger Sherman, fourth, and Robert R. Livingston, fifth. Thus fell to Jefferson the glorious task so memorably performed.

During the last session of the last Congress of the United States - such is the legacy of class hatred of Jefferson, deceiving good men - a Senator arose in all a grave Senator's solemnity - wholly unconscious of revamped Federalistic prejudices - and amusingly denied that Thomas Jefferson was the author of the Declaration of Independence, putting him down as a sort of amanuensis or "secretary" to the committee. He also denied that he was "one of the founders of the Government." It is not worth while to dwell on his first denial. Not only Jefferson's own testimony, but that of Franklin and that of Adams, settle in his favor 
exclusively the authorship of the Declaration of Independence. There is more plausibility in the denial, that Jefferson was "one of the founders of our Government," if the word "Government" be taken to mean the American Government, under the present Constitution. Of course, Jefferson was, at the time of the formation of the present Constitution, in France. But it is also true, as all of us know, that he had a great deal of correspondence, especially with Madison, and with other Virginians, in favor of the adoption of the Constitution, conditioned upon the enactment by way of amendment of what now constitute the first ten amendments - containing, for the most part, the guarantees of freedom of speech, freedom of the press, of assembly, and freedom of religion, etc. - in short, a bill of rights, and also the vital declaration, that "powers not delegated" were "reserved to the states or the people." His opposition, added to that of Henry, Mason and Lee in Virginia, would have defeated its adoption there, and prevented the formation of the new Government. This was appreciated by Madison at the time. His name, authority and letters in favor of adoption were invoked and used. Thus, even in this sense, Jefferson was one of the "founders" of the Government under the present Constitution. It is a mistake, however, to say that our Government was founded with the present Constitution. The present was an "amendment in the nature of a substitute," to the old Constitution of our Union. If not founded when the first Continental Congress convened, or even earlier as a result of the work of the committees of correspondence, then "our Government" was founded 
with the passage of the resolution offered in the name and under the instructions of Virginia, by Richard Henry Lee.

This resolution, taken up for consideration by the Continental Congress on the 8th of June, was passed, as a part of the Declaration of Independence, upon July 4, 1776, so that, in a broader sense, Thomas Jefferson was not only one of the founders of this Government, but was the designer and architect of its foundation.

After that date, there was an authorized legal government of these "United States" - however inefficient, however incongruous, and however pregnant with the seed of future dissolution.

This great Declaration was drawn by Thomas Jefferson, when he was thirty-three years of age. But, notwithstanding his comparative youth, John Fiske, one of the wisest and greatest of American historians, says that "of all the men of that time, there was perhaps none of wider culture, or keener political instincts. . . . He had always been passionately fond of study for its own sake, and to a very wide reading in history and in ancient and modern literature, he added no mean proficiency in mathematics and in physical science. . . He was deeply interested in all the generous theories of the eighteenth century, concerning the rights of man and the perfectibility of human nature; and, like most of the contemporary philosophers, whom he admired, he was a sturdy foe to intolerance and priestcraft. He was, in his way, a much more profound thinker than Hamilton, though he had not such a constructive genius as the latter; as a political 
leader he was superior to any other man of his age; and his warm sympathies, his almost feminine tact, his mastery of the dominant political ideas of the time, and, above all, his unbounded faith in the common sense of the people and in their essential rectitude of purpose, served to give him one of the greatest and most commanding positions ever held by any personage in American history."

I do not think that Mr. Fiske had any basis of historical fact for the statement that Jefferson was not such "a constructive genius," as Hamilton. As far as I know, or have thus far in my life been able to learn, Hamilton never constructed anything, except a scheme for tying the monied classes to the Government, and the government to them - a wedding knot that we have ever since been trying to undo. He attempted to construct a constitution, peculiarly unAmerican, and alien, then and now, to all the habits and thoughts of Americans. In this he totally failed. He did not construct even a financial system, but imitated, as nearly as anyone could dare, a system long before constructed in England. He did construct a system of bookkeeping in the Treasury Department, which has partially remained, as an involved curse, though Jefferson and Gallatin managed to rid us of much of it, by a process of simplification. But Fiske is exactly right when he emphasizes Jefferson's unbounded faith in the common sense of the people and in their "essential rectitude of purpose," as his great and salient characteristic. It is through this characteristic that his influence upon American political institutions, administrations, and thought has been effectively permanent. 
In a certain sense, neither Jefferson nor any other one man was the author of the Declaration of Independence. Jefferson was its draftsman, selected for the reasons which Fiske states, and selected moreover for the reason that the state papers drawn by him in Virginia had challenged admiration. But the Declaration of Independence itself was an evolution of revolutionary thought and expressed in language, certainly not mysterious to its readers, but consonant with their ripened convictions - the slow fruition of an intense struggle. Jefferson sought to express ideas, which in his mind and in the minds of his contemporaries were true and sound, in justification to the world of our action, and the more he confined himself to generally accepted ideas, the more wisely written - because the more influential - the document would be. The task was to "give the thought wings." This he did - such wings as no other man of his day could have given it such wings as no other political thing has ever yet had. Those, who would try to trace back the so-called "glittering generalities" of the Declaration of Independence to French theorists and all that, are not people who are particularly learned, but are, on this subject, particularly ignorant. The English-speaking race, in that species of political philosophy, did not follow, but preceded France. If any doubter wants to satisfy himself upon that subject, let him read John Locke's "Treatises of Government," Sidney's "Discourses on Government," and John Milton's "Tenure of Kings and Magistrates," and his "Defense of the English People."

Moreover, the fact remains, that if the English 
sources had not existed, these convictions would have developed themselves necessarily from our conditions. Our institutions and our constitutions are the product of American experience, buttressed by such written authority and historical examples as we could find in the world. A part of that experience was, of course, our experience as a part of the English-speaking race, before we landed on these shores.

Jefferson here and always diametrically opposed Rousseau's central principle, that men on coming under government "voluntarily surrender" to "majorities" their "natural rights." Jefferson's'view was that these natural rights were inalienable, and therefore could not be parted with, even voluntarily, by any generation of men. Each generation was born to them. He asserted that government was formed to protect those rights, and, if need be, even against majorities, whose "rule to be right must be just." (See First Inaugural.)

It may be true that in other places, there was nowhere an actual, historically-recorded social contract, as the source of government. But there was in America. Yet the theory, that men are equal as regards their "natural rights," and that the basis of all just government is voluntary, and contractual, was not all original with our English or American forefathers. It went back to the Roman law; being expressed in so many words in the Roman Digest (L. 17, 32), published three and a quarter centuries after Christ, and is asserted by Professor Otto Gierke to have been "an axiom of political theory from the end of the thirteenth century." All this is found abundantly amplified in Mr. Merriam's "American Political Theories." 
What was new in America was not the doctrine, nor theory as a basis for reasoning, but the object lesson of it. I cannot too often emphasize the thought, that this was due to the fact that we had our beginnings in the woods.

Merwin says of the Declaration of Independence that "both as a political and a literary document, it has stood the test of time. It has all the classic qualities of an oration by Demosthenes; and even in that passage in which it has been criticized - that, namely, which pronounced all men to be created equal - is true in a sense, the truth of which it will take a century or two yet to develop."

In fact, a peculiar excellence of this and many other utterances of Mr. Jefferson is, that in them lie thoughts in advance of his time - germs destined to multiply and take possession. Here and there he puts in "a little leaven," which, at the time, is hardly noticed, but will later "leaven the whole lump."

It remained for Lincoln later on to take up what were called the "glittering generalities" of the Declaration of Independence, to muster them into practical political service, saying that they were meant "to declare the right, so that enforcement of it might follow, as soon as circumstances should permit," and that their expression had been "constantly looked to, constantly labored for, and even though never perfectly attained, constantly approximated, and thereby constantly spreading and deepening its influence, and augmenting the happiness and value of life to all people of all colors everywhere."

As we have seen, Mr. Jefferson, before submitting his 
draft of the Declaration of Independence to the full committee, communicated it separately to Franklin and Adams. They made two or three suggestions, merely verbal, and these were adopted.

The original paper in Jefferson's handwriting, with Adams's and Franklin's interlineations, is in Washington. It has been frequently published in fac simile and is a thing of common knowledge. Mr. Adams is thus mistaken in saying that he himself did not make or suggest a single alteration. $\mathrm{He}$ and Franklin each suggested some purely verbal changes, which Jefferson at once accepted. With regard to matters of which he had personal knowledge, Jefferson's memory was almost invariably accurate. A man hunting inconsistencies of opinion wherewith to charge him would find his labors somewhat rewarded, as he would concerning any other man possessed of a growing intellect and a progressive character.

When the draft reached Congress, those passages which censured the people of England were stricken out, and the clause which censured the King for acts enslaving inhabitants of Africa and bringing them to the shores of America was also stricken out. Jefferson says, that this was done "in complaisance to South Carolina and Georgia," adding: "Our northern brethren also, I believe, felt a little tender under these censures; for though their people had very few slaves themselves, yet they had been pretty considerable carriers of them to others."

Whatever may be said of the policy of Congress in striking out that part of the Declaration which censured the people of England, it cannot be said, that it made 
the Declaration to accord better with the facts of history. As it is, George III and Parliament alone are held up to blame. There is no doubt about the fact that, at the beginning, at any rate, and until very near the end of the struggle, the people of England were in accord with their King and Parliament.

Lord John Russell, in his "Life of Fox," Volume 1, page 134, makes this clear. Jefferson, as usual, was right, and his correctors wrong. He was right, too, with regard to that part of the draft, which referred to the slave trade. Whatever may have been the case in other colonies, in Virginia, at any rate, the utmost effort had been made to stop it; a half score or more of acts had been passed, only to be vetoed by royal governors under royal instructions.

Concerning the Declaration itself, Adams later, in a letter to Pickering, in the year 1822, says: "As you justly observe, there is not an idea in it but what had been hackneyed in Congress for two years before." He adds: "The substance of it is contained in the declaration of rights, . . . in the Journals of Congress in 1774. Indeed, the essence of it is contained in a pamphlet, voted and printed by the town of Boston, before the first Congress met, composed by James Otis, as I suppose, in one of his lucid intervals, and pruned and polished by Samuel Adams."

Mr. Jefferson, on seeing this - which had been greedily published by Pickering - with a forbearance characteristic of him, when dealing with Mr. Adams, except for a few brief months of his life, when he was provoked into retaliatory utterances - nobly and modestly said:- 
"Pickering's observations, and Mr. Adams's in addition, 'that it contained no new ideas, that it is a commonplace compilation, its sentiments hackneyed in Congress for two years before, and its essence contained in Otis's pamphlet,' may all be true. Of that I am not to be the judge. Richard Henry Lee charged it, as copied from Locke's 'Treatise on Government.' . . . Otis's pamphlet I never saw, and whether I had gathered my ideas from reading or reflection, I do not know. I know only that I turned to neither book nor pamphlet, while writing it. I did not consider it, as any part of my charge, to invent new ideas altogether, and to offer no sentiment which had ever been expressed before. ... Whether, also, the sentiments of independence, and the reasons for declaring it, which made so great a portion of the instrument, had been hackneyed in Congress for two years before the 4th of July, '76, or this dictum also of Mr. Adams be another slip of memory, let history say. This, however, I will say for Mr. Adams, that he supported the Declaration with zeal and ability, fighting fearlessly for every word of it."

The curious reader may consult the pamphlet of James Otis, the Declaration of Rights and the Journals of Congress, and determine for himself how far $\mathrm{Mr}$. Adams's afterthought was well founded. He will find it in no true sense justified. If any publication furnished more than another foundation for the Declaration, it was Jefferson's own "Summary View of the Rights of British America," and his "Reply to Lord North's Conciliatory Proposal." Another truth is that the Committee on Rights and Grievances, whose report was drawn by John Adams, in September, 1774, contained substantially much that was in Jefferson's "Summary View." The "Summary View" was presented to the Convention of Virginia before the Congress of 1774 met, and the Committee of Rights and Grievances had access to that paper. Thus the borrowing, if 
there were any conscious borrowing, was a borrowing by Adams from Jefferson, and not the other way. There is, however, no plagiarism in either. Jefferson had neither paper, book, nor pamphlet before him when he wrote the Declaration, and it is presumbably also a fact that Mr. Adams had none when he wrote the Report on Rights and Grievances, though both had in their minds many fixed and popular ideas, which had become trite, and, many of them, ideas advanced and rendered popular by Jefferson in his "Summary View," so widely disseminated not only in America but in England.

The Declaration accomplished its end. It went to the comprehension of the average man with overwhelming force. It was full of "keynote phrases." It was "quotable" - began at once to be quoted and has been ever since. Every American became a Dick Swiveller of its phrases. It gave unity of expression to the American people. It was received everywhere with enthusiasm; ordered to be read at the head of the armed forces; people, after hearing it, tore down statues and pictures of the king and of colonial governors. They also welcomed it in churches with prayers and sermons.

We have seen that when the Virginia Convention instructed their delegates in Congress to introduce a resolution declaring American independence, they also appointed a committee to draw up a "declaration of rights," as they called it, and a "plan of government" for Virginia. Mr. Jefferson prepared and forwarded from Philadelphia the outline of a plan. It reached Virginia too late, because the Bill of Rights and the Constitution of Virginia had been agreed to, 
but the lofty preamble of Mr. Jefferson's plan pleased the committee so much, that they prefaced it to the great work of George Mason - the first Constitution of Virginia, and the first in America to be written by the representatives of the people - which was passed on June 20,1776, the day after the draft of the Declaration of Independence was reported to the Continental Congress. This preamble was drawn by Jefferson, therefore, prior to his composition of the Declaration. He says, after dwelling upon that fact: "Both having the same object, of justifying our separation from Great Britain, they used necessarily the same materials of justification, and hence their similitude."

I mention this, because in the constant efforts of those who hated and hate democracy to write Jefferson down in his lifetime and after his death, every little thing has been taken advantage of, in the attempt to decrease his credit, and among other things, he was accused of having plagiarized parts of the Declaration from the Preamble of The Constitution of Virginia; in other words, from himself.

The opening sentences of the Declaration of Independence are frequently referred to as a part of some sort of French infection. In the first place, the French revolution had not begun, and, in the second place, there is not an idea contained in it, that is not purely Jeffersonian.

By the way, I love very much a phrase which Fiske uses as the caption of one of his chapters: "Thomas Jefferson, The Conservative Reformer."

This quotation from it, I recommend to all readers:- 
"Because in later years Jefferson came to be the head of a party which sympathized with revolutionary France, there has come into existence a legendary view of him as a sort of French doctrinaire politician and disciple of Rousseau. Nothing could be more grotesquely absurd. Jefferson was broad enough to learn lessons from France, but he was no Frenchman in his politics; and we shall not understand him until we see in him simply the earnest, but coolheaded, representative of the rural English freeholders, that won Magna Charta and overthrew the usurpations of the Stuarts."

Cornelius de Witt, after analyzing much of the historical and legal parts of the Declaration, says:-

"The other principle was that of the rights of man. The Declaration of Independence contained a list of rights, such as were familiar to the colonists of England, but were only theories elsewhere. The success of the Revolution was, therefore, a shock to the system of privilege and of class exemptions from the common burdens, which had lasted since feudal times. The French Revolution of 1789 was an attempt to apply upon alien ground the principles of the American Revolution." (Italics mine here and always.)

If there was any drawing of ideas either way, the French revolutionists drew from America and from the Declaration of Independence. Many of the French officers and soldiers went back to France with ideas, which, perhaps, would have been altogether unfamiliar to them - except for their sojourn in America. It may be a "glittering generality" - I don't know but I rather regard it as a golden actuality, founded upon everlasting truth, that men are "endowed by their Creator with certain inalienable rights, among which are life, liberty, and the pursuit of happiness," if only the last be honest, pure, peaceable and fair.

Nor do I regard the latter part of that clause in the Constitution, which says that all powers not delegated 
to the federal government are reserved to the states respectively "and to the people," as a "glittering generality." I do understand this clause reserving certain rights "to the people," to mean just this class of natural and inalienable rights - antedating and superior to all governmental authority. In this class are freedom of religion, freedom of speech, freedom of association, the right of petition, freedom from unreasonable search and arrest - in fact, everything in that vast realm where the individual is his own governor, and responsible only to God - a realm whose boundaries are located just where the exercise of his freedom begins to interfere with the right of others to preserve their life, or limb, or property honestly acquired. I count it a great happiness for the American people, that they did not base their claims altogether upon the rights of British subjects and upon the black-letter of the law books, but, fundamentally, upon the natural rights of man, and especially upon the right of any community, for a reason seeming necessary to that community, to change the form, or set aside the substance of a government, unjust and oppressive, and to establish in its stead one concordant with the public welfare, with human freedom, with equality of rights and opportunities, and equal administration of justice; a new government, "deriving its just powers from the consent of the governed." As Merriam well says: this theory that governments derive their just powers from the consent of the governed "could hardly be called a theory at all." It is the American "working hypothesis."

Not only did the individual have under it certain 
rights, that were inherent and inalienable, but out of this grew $e$ converso the fundamental principle, that the sovereignty of the people is inherent and inalienable, with regard to things not fundamentally individual, or, as Roger Williams said, things not "of the first table."

Many people wonder why it was that so many people in the South, and especially in the border States, denied "the right of peaceful secession," and said that there was no law for it, either statutory or constitutional, yet "went with their States." They stood upon "the right of revolution" - the right of a people of a State, if in their opinion the federal government became sectional, oppressive or unjust - or threatened to become so - to throw it off; to "dissolve the ties that bound them to it," as the phrase went, and, if opposed in this, to take the field in armed assertion of their right to be permitted "to go in peace," as Sweden of late permitted Norway to go. This was the view of my own father. It is easily explicable, if you will remember, that these people, perhaps more than any other, were permeated with the political theory of the revolutionary period, although perhaps the most radical utterances of this theory earlier in our history had come from New England. Practically, of course, this sort of right rests ultimately on the acquiescence of others, or else upon the power of the community to assert it successfully with arms in its hands. But it is not too much to say that the more moderate expression of the idea still radical, but not so extremely radical - contained in Jefferson's ringing words in the Declaration of Independence - was almost universally entertained in America in his time. In fact, most Revolution-time 
Tories denied only that the exigency had come to justify the exercise of "the right of revolution," and either denied the grievances, or else asserted that grievances could be redressed more certainly and safely without resorting to so extreme a revolution as independence. A like opinion was that of many Union men in the South - some 300,000 of them in the Union armies - who fought and some died acknowledging the right, and denying that the occasion justified its invocation. This more moderate expression contained in the Declaration is, in these words, familiar to all: "Whenever any form of government becomes destructive of these ends, it is the right of the people to alter or to abolish it, and to institute a new government, laying its foundations on such principles, and organizing its powers in such form, as to them shall seem most likely to effect their safety and happiness."

Pennsylvania, in her first constitution, asserted that "the community hath an indubitable, inalienable and indefeasible right to alter, reform or abolish government in such manner as shall by that community be judged most conducive to the common weal." By the way, I like that old expression, "the common weal." I once used it in the draft of a plank in a Democratic national platform and the "finishers," supposing that I had made a slip of the pen, changed it to "commonwealth!"

This very theory grew out of the doctrine of delegated powers - the doctrine that all governmental power is delegated by the people, in whom it ultimately resides; that there are rightfully no inherent governmental powers; that government is the grantee of powers, and not the 
grantor of rights; that it is merely the agent, or servant, of the people; a trustee acting (if acting rightly) for the people, and not for itself. Our forefathers knew the danger of excess of government and were bent upon so simplifying, limiting and checking it, that it must forever remain a servant and could never become a master. My reading of history convinces me that most bad government has grown out of too much government. It is a sort of inherent characteristic of all government, as of all conscious organisms, yearly and almost daily, to take to itself more and more jurisdiction, to increase the force and weight and numbers of officialdom, until, after a while, the structure becomes topheavy, and must fall by its own weight; or else, upon the other hand - remaining administratively efficient - it holds the people in servile subjection. I know of no government, which has ever once been strong and then fallen (except where it has been conquered by outside force), that did not go to its ruin because it had become gradually, even insidiously, cumbersome, topheavy, unwieldy, complicated, almost incomprehensible; in a word, had assumed to itself more powers than could possibly be wisely administered by fallible men. Tom Jefferson did not attach a particle too much importance to the simplification of official life and governmental machinery. In him, as has been well said, was "crystallized the common American sentiment."

The main difference between Jefferson and his opponents - as well as between him and the other extreme, Rousseau and his school - is this; both schools opposed by him contended that we gave up 
certain "natural rights," when we formed our government - one to "government" and the other to majorities. He contended that the business of government was to make these natural rights more secure; that its chief business was to be a fence around them and a bulwark of protection for them. In his view, government is not an end, but a means - a means to defend and increase the liberty and happiness of the men and women living in the country governed, who, however, are the safest, and the only rightful guardians of their own private concerns; that government is good in proportion as it is responsible to and supervisable by the people.

Jefferson maintained truthfully, too, I think, that men were divided politically into two classes; those who fear and distrust the people, and those who identify themselves with the people, as a part of them.

I heard Governor Woodrow Wilson once express it very well in designating the first class as men, who spoke of "the people" as something outside - beyond themselves. There is nothing more significant than one's way of looking upon the people; one man looks at them as an alien thing, and another sees himself in them, or perhaps better, sees them glassed in himself.

In a letter to Du Pont de Nemours, which may be found in Jefferson's "Works," Volume 10, page 23 (Washington edition), we find this language: "We both love the people, but you love them as infants, whom you are afraid to trust without nurses, and I as adults, whom I freely leave to self-government."

Of course, no sincere man ever professed perfect confidence in the people doing the right thing at all 
times, but the difference is one of degrees of approximation to perfect and perpetual confidence. Men like Hamilton habitually distrusted the masses, because they sincerely did not believe that the masses had brains enough to understand things, and to do them. They wanted strong government to restrain the people. Men like Jefferson wanted a strong people, to restrain the government, and knew that the moral sense, inborn in men, has as much to do with right government as intellect or any other one thing.

The fiftieth anniversary of the Declaration of Independence, the day upon which he and John Adams were destined each to draw his last breath, was approaching. The Mayor of the city of Washington, in the name of its citizens, had invited Jefferson to be present at its celebration in that city. On June 24, 1826, he wrote a letter to the Mayor, a Mr. Weightman. In that letter, speaking of the Declaration of Independence, he says:-

"May it be to the world, what I believe it will be (to some parts sooner, to others later, but finally to all), the signal of arousing men to burst the chains under which monkish ignorance and superstition had persuaded them to bind themselves, and to assume the blessings and security of self-government. That form which we have substituted restores the free right to the unbounded exercise of reason and freedom of opinion. All eyes are opened, or opening, to the rights of man. The general spread of the light of science has already laid open to every view the palpable truth, that the mass of mankind have not been born with saddles on their backs, nor a favored few booted and spurred, ready to ride them legitimately, and by the grace of God. There are grounds of hope for others. For ourselves, let the annual return of this day forever refresh our recollections of these rights, and inspire an undiminished devotion to them." 
'Note: It is the "Rights of Man" yet, as in his youth. It is no "glittering generality" to him. God grant that it may never be so to us!

This again indicates how Jefferson's mind inevitably refused to confine its vision, when contemplating the blessings of liberty and democracy, to American territory, and how invariably it wandered out to the utmost confines of the earth, wherever there were men with rights to assert and with duties to perform. His was, in the broadest and finest sense, a world-democracy. He appreciated, too, what few men appreciated when he wrote them, that the broad abstract expres sions of the Declaration constituted a logos; a word to go out, a germ to grow rather than a statute presently to demark.

Like so many old men, when dying, his mind went back to the scenes of activity in which he had been engaged in his early manhood. Partially arising in the bed, and using his right hand, as if writing upon a tablet held in his left, he exclaimed: "Warn the com. mittee to be on the alert!" It was like Stonewall Jackson's exclamation, "Order A. P. Hill to prepare for action!" "Warn the committee to be on the alert!" What committee? Doubtless, one of the old committees of safety of the revolutionary day, who not only constituted a provisional government, but exercised disciplinary authority over the disaffected and the disloyal, and whose duty it was to defeat any counterrevolutionary movements or combinations. "The ruling passion was strong in death," and we may be sure that Jefferson's right hand had written many a message similar to this last exclamation. 
Mr. Merriam informs us that "by the later thinkers the idea that men possess inherent and inalienable rights of a political or quasi-political character, which are independent of the state, has been generally given up." Pity it is, if true! He adds in another place that "the present tendency in American political theory is to disregard the once dominant ideas of natural rights and of the social contract, although it must be admitted that the political scientists are more agreed upon this point than is the general public." I should hope so! I would hate to see the idea prevail among the people that liberties are a grant of government, instead of government being a delegation of power by the people, and I predict it never will until the downfall of this "Republic of Lesser Republics."

Some of the latter-day political "scientists" seem to want the world governed by experts. One of them speaks of a "central academy of science, which shall stand in the same relation to the control of men, in which a polytechnic institute stands to the control of nature!" In other words, individual rights and liberties are to count for nothing in comparison with scientific efficiency of bureaucratic administration. One of them does admit that "social interference" (that is, governmental interference) "should not be so paternal, as to check the self-extinction of the morally ill-constituted; . . . nor should it so limit the struggle for existence, as to nullify the selective process." Thank God for small favors! The right of selfextinguishment at least is still left us by college governmental scientists!

These people, it seems to me, forget the two great- 
est of facts - God and The Man. They forget the Individual, who is born and comes into the world, and who dies and goes out of it alone, with no company save the Divine Individuality. However, I suppose a reference to that is "unscientific."

There is an American political theory, right or wrong, and it is Jefferson's theory. When he overcame the Counter-Revolution, he made it ours by a new birth a regeneration.

It is a curious thing that no new party has broken away from the old ones without founding itself allegedly upon the views of Thomas Jefferson and the doctrines of the Declaration of Independence, and that just in the measure that old parties desert them, just in that measure can you forecast their defeat. This was the case, of course, with Democratic-Republicans - the party founded by Jefferson. It was the pretention of the early Whigs. It was the assertion of the early Republicans, and notably of Abraham Lincoln; and it is curious that in the so-called "Bull Moose" Convention - during this year, Jefferson's portrait was hung conspicuously high, and the party pretended to draw faith from him, notwithstanding all the sneering and unjust things that had been written about Jefferson by Mr. Roosevelt, its candidate. This Declaration of Independence was a summary expression, in Jefferson's words and manner, of what had become the common and characteristic thought of a majority of the American people, and was intensely his own. It remains the common thought of the American people, and constitutes the Soul-Politic, which dwells within and animates and energizes our Body-Politic. 
The salient points of this theory are: first, natural, inalienable, God-given individual rights - "the things of the first table;" secondly, local self-government, with most numerous and important powers conferred upon that part of the government, which is nearest the individual citizen - with less and less power delegated to each other government which controls him, in proportion as it is further away; until finally, the least of all jurisdiction is delegated to that government, which is most distant from him and which he can watch least well, and which can know least well his wants and interests.

The Jeffersonian theory involves a distinct demarcation between state and national powers. It involves, yes, necessitates, an educational system to inform a public opinion, which shall thereby become fit to rule and govern. To this I shall refer later.

None of the attacks upon democracy, based upon the errors and impulses and the wild passions of revolutionists in France, South America, or elsewhere, has ever for long shaken the American people's confidence in their doctrine.

It is curious that, while American writers have deceived themselves so much about the source of the principles which actuated Thomas Jefferson, referring many of his opinions back to the French philosophers, etc., the French writers, as a rule, make no such mistake. Cornelius de Witt, who had made some study of our revolutionary period, says:-

"Sauf Montesquieu, nos écrivains y étaient peu lus et peu cités. Coke, Milton, Locke, Grotius, et surtout la Bible, la grande charte, le common law, l'histoire d'Angleterre, les chartes et les histoires 
locales, telles furent les autorités qu' invoquèrent les tribuns, les prédicateurs et les pamphlétaires qui excitèrent le peuple américain a combattre pour ses droits. Je n'ai jamais recontré dâns leur bouche, ni le nom de Rousseau, ni l'expression du souveraineté du peuple."

\section{IN FRANCE}

How much influence Jefferson had upon the actors in the early stages of the French Revolution nobody will ever know. Both the modesty of the man and his delicate situation as Minister to France prevented his telling it. But on July 9, 1789, the Duke of Dorset, British Ambassador at Paris, wrote to the Prime Minister: "Mr. Jefferson, the American Ambassador at this court, has been a great deal consulted by the principal leaders of the Tiers Etat; and I have great reason to think that it is owing to his advice that the order called itself L'Assemblée Nationale." If so, this was the initial step, without taking which the Third Estate and democracy were lost. It was the sine qua non of all that came after.

In a letter to Madison in 1789, Jefferson speaks of the French revolutionists regarding us as "a model for their imitation," and says: "Our [authority] has been treated like that of the Bible, open to explanation, but not to question."

The American Revolution had been in a double sense one of the causes of the French Revolution. First, it sent back to France besides private soldiers, who had opened wide their eyes at the spectacle of a country without nobility or peasants, also young captains and colonels and majors and a few generals even - generally of the poorer nobility - who had caught the American spirit and found it incompatible with the 
ancien régime and preferable to it. But it was a cause of the French Revolution in another and sadder sense. The American war had cost the court of France a great deal of money, had contributed to the consumption of its funds on hand, almost to the destruction of its credit.

We may imagine how Jefferson, whose Declaration of Independence, whose "Summary View," whose preamble to the Virginia Constitution, whose statute of Religious Freedom, and, finally, whose liberal sentiments scattered here and there in the "Notes on Virginia" had made him a forerunner in the expression and advocacy of "the rights of man," became the consultee and counsellor of the so-called patriotic party. His habit of arriving at political principles by deduction, while also relying on legal and historical authority, was a habit which he carried to France and did not bring away from there, except in the shape in which he had carried it. The former is a Celtic trait. Jefferson was Welsh - a Celt. But it did not turn his head. In fact, his advice to the French revolutionists - to Lafayette especially - was upon much more conservative lines than any declaration of policy ever made by him in America, than any political act of his in America. In France, as in America, he reasoned that the best attainable should be procured, and he realized that the best attainable in France at that time was far, far, behind the best attainable in America. Cornelius de Witt says that "it was in Paris Jefferson learned to abhor the whole social organization of Europe and everything appertaining to it still existing in America; it was in Paris that he learned to hate the power both 
of the aristocracy and clergy, which till then he had opposed without any irritation." And Hazen, in his "Thomas Jefferson and the French Revolution," says that, after his stay in France, his utterances became "not the sober thought of a judge, but rather the war cry of the republican militant."

Through it all, he seems to have seen clearly that for which the French people were "ripe," to use his favorite word. Jefferson knew the great truth, that a given thing may be a bad thing for one place and time, and a good thing for another. Hence he advised the British model as a working initiative government for the French, while he afterwards in America spent his whole life denouncing the same model, as a thoroughly unfit thing for the American people, who had long since passed the stage of growth, when that suit of clothes could fit them. I find no more inconsistency in this than in a physician's giving a delirium tremens patient moderate doses of whiskey, that he may not die from shock to his system, by sudden change.

Those who dwell upon the failure of the French Revolution to accomplish step-by-step progress without violence, and call Jefferson a doctrinaire, because he hoped it, forget that the experiment was tried under more unfavorable circumstances than perhaps a similar experiment was ever tried anywhere else. In a bread famine, during an unprecedented cold winter, amidst the clash of arms, with desperate and reckless traitors to be put down at home, it would have been a miracle, if an untrained crew upon the ship "Institutional Reform" had been held in discipline.

Up to the time that Jefferson left France, there was 
doubt, of course, and apprehension of failure, which he himself expressed, but there was no reason to despair of a successful issue.

Hazen concludes that Jefferson "sailed for home with the conviction that within a year one of the greatest of recorded revolutions would have been effected without bloodshed." This is inaccurate. Had he said, "with the hope," instead of "with the conviction," he would have been right, for Jefferson's letters from France are full of expressions of uneasiness and apprehension. Hazen adds: "And when the bloodshed began in grim earnest, he refused to see its significance, minimized its importance, and was reluctant to believe that a beautiful dream might become a hideous, repulsive monstrosity." If all this were true, it would not be to Jefferson's discredit. But it is not true. He did see its significance; he did regret its necessary bearing; he did see the present "hideous, repulsive monstrosity," but he saw something behind it, or rather ahead of it. $\mathrm{He}$ saw the ultimate issue - liberty and a new era - not only for France, but for the European race. He minimized the "present hideousness" only in the sense that he thought the ultimate result was worth purchasing, even at the cost of such days of terror, as seemed in the providence of God necessary to be endured, in order to topple over despotism, special privilege, priestcraft, and all forms of rule by the "booted and spurred," trained to believe that the masses of mankind are "bridled and saddled." Most of us see now what Jefferson saw then, and what Burke did not, and Adams did not, and Hamilton did not see. $\mathrm{He}$ was one of the very few well-born, wealthy and 
respected men in America to see it then. Not as many lives were lost by the guillotine as in many a single battle, fought about next to nothing and in some few battles fought to maintain the amour propre of a king's mistress. Nor were there as many lives lost by the guillotine, probably, as many a single generation of kings and nobles and priests had snuffed out, in an equal length of time, as the result of poverty, neglect, insanitation, and overtaxation, caused by general misgovernment.

Jefferson saw all this - all honor to him for having seen it, and for having refused to permit himself and his followers in America to be dragged into a senseless American counter-revolution, because a people blindly and brutally striving for liberty in France had temporarily failed, and had failed no more by their own ignorance and cruelty, than by the hostile coalescence of kings, and of beneficiaries of special privilege, all over Europe. It must never be forgotten that the domestic violence in France was but a protest - blind, unreasoning, barbarous - but still a protest, against this coalescence between privileged enemies of popular right at home and the beneficiaries of monarchical, aristocratic, and plutocratic privilege abroad - kings, nobles, ecclesiastics, and fund-holders. Truly Jefferson came back from France "a republican militant." Happy for us that he was in France, so to come back!

A letter to Mr. Short, dated January 3, 1793, shows how Jefferson, unlike so many other intelligent men in America and in England, saw, beyond the struggle and the bloodshed, to the hoped-for issue itself - saw the things that were to be permanent and not temporary. 
After describing how the French people had become Jacobins by the almost necessary stress and drive of circumstance, he says:-

"In the struggle, which was necessary, many guilty persons fell without the forms of trial, and with them some innocent. These I deplore as much as anybody, and shall deplore some of them to the day of my death. But I deplore them, as I should have done had they fallen in battle. It was necessary to use the arm of the people - a machine not quite so blind as balls and bombs - but blind to a certain degree. A few of their cordial friends met at their hands the fate of enemies. But time and truth will rescue and embalm their memory, while their posterity will be enjoying that very liberty for which they would never have hesitated to offer up their lives. The liberty of the whole earth was depending upon the issue of that contest. Was ever such a prize won with so little innocent blood?".

By this time Gouverneur Morris was in Paris and was becoming very "properly" "disgusted" with the fact that "booksellers and venders of skins and grocers" were being placed in civil office! It was not to be long before John Adams would in America voice this same high-flown contempt for common folks. We find Mr. Morris about this time - at least his Memoir says so - urging Lafayette "to preserve, if possible, some constitutional authority to the body of the nobles, as the one means of preserving any liberty for the people." Isn't that "going some" for an American, who almost thus far had been getting on very well without having ever met a nobleman, except of the God-made sort? We find him commenting unfavorably upon the fact that "Jefferson, with all the leaders of liberty here, is desirous of annihilating distinctions of 
order"! This was not quite true, as a matter of fact, because Jefferson had not yet thought it wise to go that far in France. He was emphatically urging, however, the withdrawal of the hurtful special privileges of the clergy and nobility, which exempted them from taxation and made all the heavy services and taxes fall upon the poor.

Jefferson did not confide in Morris, who knew nothing of what he wanted. At that very time and up to the day he left France he believed that France was not yet ready for anything more than a limited constitutional monarchy. As late as November 18, 1788, he says, in a letter to Mr. Madison speaking of the French people: "The misfortune is that they are not yet ripe to receive the blessings to which they are entitled."

$\mathrm{He}$, nearly first of all English-speaking great men, saw the immense influence of the example of France upon the civilization of the world. He writes: "I considered a successful reformation of government in France as insuring a general reformation through Europe, and the resurrection to new life of their people now ground to dust by the abuses of the governing powers." Long afterwards it came to be a generally recognized fact that eonvulsions in France were always followed by convulsions all over Europe - as in 1830 and 1848.

It was doubtful if, in advising an understanding with the court, on the limited monarchy basis, Jefferson was wise. The fight had by now gone too far. It had recently become evident that the sincerity of the court and of the courtiers simply could not be relied 
upon. The people were compelled to do one of two things, and they soon realized the fact - either desist from their struggle for liberty, or else intimidate the aristocracy.

The charter which, at the request of some of the patriotic party, he drew up, can be found in his works, either edition. It was an immense step forward for the French people.

Gouverneur Morris and Jefferson never did each other justice. They were men so far apart in temperament and in political creed that it was well nigh impossible. Morris was cynical, sneering, distrustful of every sort of elevating sentiment - the hard, practical man of affairs; - fond of speculation, withal - yet acute; honest, but utterly incapable of believing that anybody professing a faith in the rule of the masses of the people could be otherwise than hypocritical. Jefferson was as we know him to be.

Jefferson saw clearly the real causes of the French Revolution - saw too that its excesses were not to be charged solely to the passions and cruel vengeance and ignorance of the people, but in just proportion also to the long oppression which had preceded and produced their ignorance, and to the almost fiendish contempt for the people, which had had its result in arousing avenging passions against the noblesse who entertained it. Carlyle afterwards, partially, and Charles Dickens, very clearly, saw what Jefferson did, but neither quite as sympathetically. How clearly he saw it all would be, if I had space or time, worth demonstrating at the risk of tediousness. 
When, on the 4th of August, the National Assembly abolished all class privileges, Jefferson says: "Thus there went down at one sweeping blow all titles of rank, all the abusive privileges of feudalism, the tithes and casuals of the clergy, all provincial privileges." Then the Declaration of Rights was adopted, and then a committee appointed to draft a constitution, and then that most extraordinary compliment paid to $\mathrm{Mr}$. Jefferson, when the chairman of this committee wrote him a letter, dated July 20th, requesting him to "assist" at their deliberations. Of course, Jefferson knew better the duties of an ambassador than to take any such open and public part in the formation of the constitution of a country, to the court of which he was accredited. It shows, nevertheless, the remarkable influence of the man, which was demonstrated throughout his life, wherever he happened to be.

Here Jefferson ceased to be a spectator of the great European drama. It will be noted that it was before the great excesses which shocked the civilized world had occurred.

Parton says, in his "Jefferson's Return From France" - Atlantic Monthly, 1872 - and I am glad to find somebody who agrees with me about that:-

"The narrative of events written by Jefferson in extreme old age, brief, cold and colorless as it is, taken in connection with his numerous letters, official and private, written at the time, will be prized by the individual, who will, at length, evolve the French Revolution from the chaos of material in which it is now involved. Unfortunately, Jefferson went too far in extirpating his egotism. He was not vain enough; he was curiously reticent concerning his own part in important events; he instinctively veiled them and his 
personality. But for this, he might have found time in his busy retirement, to compose a history of the Revolution down to the taking of the Bastille, which would have been of imperishable interest. It was not merely that he knew the men and witnessed the events, but he preserved his incredulity, accepted nothing upon mere rumor, and personally investigated occurrences. If a rumor reached him that 'three thousand people had fallen in the streets,' he and his secretary, Mr. Short, would go to the spot, and, after minute inquiry, reduce the number to 'three.' He was unwearied in sifting out the interminable sessions of the various assemblies, and thought little of riding to Versailles 'to satisfy myself of what has passed there, for nothing can be believed ("here") but what one sees or has from an eye witness." "

Jefferson had been in constant association with the chief spirits, who constituted the moderate monarchical, and the moderate republican, membership of the French legislative body. He supplied them with books and literature, wrote for them a discourse on the jury system, recommending it because it gave an "infusion of the people in the transaction of affairs," which was "necessary to the preservation of purity."

In connection with Jefferson's views of the French Revolution, it must be remembered that he had studied and understood the condition of the French peopleas well as the follies of their government; that he had "felt of their beds to see how they slept;" that he had "looked into their pots" to see if there were soup or fowl in them; that he was in a better position, than any other American of his day, to make due allowance for the excesses which after his departure ran riot amongst a sorely provoked people - a people, who, in addition to the drawback of inexperience in self-government, had had the hot iron of contempt and oppression thrust 
into them and turned around in the wound, until their hearts were aflame with a spirit of revenge, as well as with a desire for their share of the earth's freedom and happiness. Most Americans put the French in their own positions and judged them accordingly. Jefferson tried to put himself in their place, and did it very wellconsidering that he was philosophe and they were enragées. 


\section{CHAPTER III}

JEFFERSON THE DEMOCRATIZER OF STATE INSTITUTIONS

\section{A STATE MADE OVER}

I DouBT if there is anything sweeter in Mr. Jefferson's life than what he says in his Autobiography in the following modest way:-

"I have sometimes asked myself whether my country is better for my having lived at all. I do not know that it is; I have been the instrument of doing the following things; but they would have been done by others, some of them, perhaps, a little better."

Then there follows a reference to four great measures - three of which were afterwards inscribed on his tomb, the other being the abolition of primogeniture and entail.

Note that the things he took most pride in were all, save one - the authorship of the Declaration - state, not federal, acts. Note the same fact in the inscription chosen by him for his tomb: "Author of the Declaration of Independence and of the Virginia Statute for Freedom of Religion and Father of the University of Virginia."

It has been a sort of fashion to speak of Thomas Jefferson as a "theorist," "doctrinaire," and all that. Very few people know how great he was as a constructive statesman - a legislator. In the first place, Mr. Jefferson was an excellent lawyer - not a great 
advocate, because he was never an orator, nor even a very great debater. His vocal defects, as noted elsewhere, prevented this.

He was only thirty-three, when he resigned from Congress and went back to Virginia, there to begin his wonderful work of political and social and industrial reconstruction. His reason for it is best given in his own language: -

"When I left Congress in 1776, it was in the persuasion that our whole code must be revised, adapted to our republican form of government, and, now that we had no negations of councils, governors and kings to restrain us from doing right, that it should be corrected in all its parts, with a single eye to reason, and the good of those for whose government it was formed."

Every law that he introduced was in itself a reformation, far reaching in its ends, conservative in its methods. Let us run over, rapidly, the acts of constructive legislation, of which he was the author, leaving details as to their bearing, effect, origin, or date of passage to later comment: An act defining treason, and abolishing corruption of blood as a part of its punishment, thus refraining from visiting upon the heads of the innocent the guilt of the offender; one defining citizenship, being the first legislative assertion in the world of the right of expatriation, the first denial of the doctrine of indefeasible allegiance, under which kings claimed men's bodies and services for life and defied the natural right of the individual to adopt a new country. This has since become an American principle. His acts abolishing estates tail; abolishing primogeniture; establishing freedom of religion; his bill, which failed to be fully enacted, establishing a thorough 
system of education; the magnificent preamble to the first constitution of the State of Virginia; the bill of 1784 for the government of the Northwest Territory, the precedent for our territorial system of government; his bills, which became law for the simplification of the court system of Virginia; his act prohibiting the importation of slaves into Virginia; his amendment for the emancipation and deportation of slaves, which failed, it is true, but barely failed; the laws for the establishment of a State University, all of which he drafted; his bills reforming the criminal laws of the State of Virginia, and abolishing the barbarous practice of drawing and quartering; his protest against the revolting feature of the lex talionis; the removal, under his recodification, from the Virginia/criminal laws of the death penalty in twenty-seven cases - in all cases except treason and murder - a third of a century or more before the great English law reformers, amongst whom Romilly stood first, succeeded in reaching a like result in Great Britain. All of these things were not the promises of a theorist, but the accomplishments of a practical constructive statesman. "The multifariousness of his work is equalled in credit to him by the lucidity of the language in which it was dressed. How many of them were the first examples of their kind? The act defining citizenship, I have mentioned; his amelioration of brutal penalties, the first example of that sort of legislative humaneness perhaps anywhere, certainly in the English-speaking world; his act of '78 was the first American law to abolish the foreign slave trade, and became a legislative fact $\mathrm{R}$. G. H. Kean, in "Thom Jeffersun as a Eegistatu," "when 
Thomas Clarkson was a sehool boy.". (His statute of religious liberty letuer was the first example in a Christian country of absolute freedom of public worship, not only for all Christians, but for all religionists of every sort guaranteeing freedom of belief and freedom of worship - cutting off all possible forms of legal persecution, and all control by the State of either religious conviction or religious observance. He worked a reformation in his tools, too, the law language, with its "saids" and "aforesaids" and its endless tautologies and repetitions. $\mathrm{He}$ himself gives a very fair resumé of the most important of the legislative reforms he introduced in Virginia, and with accustomed self-abnegation and lack of desire to glorify self, never once mentioning that he - the youngest of them - was chairman of the committee composed of himself, Edmund Pendleton, George Wythe, George Mason and Thomas Lightfoot Lee, and that upon him as chairman fell the main burden of the work. The fact is that he and George Wythe substantially did it all -Mr. Pendleton's part was recast and reformed by the two, owing partially to the fact that Mr. Pendleton misunderstood the program, and still more, perhaps, to the fact that he was called away by sickness.

Randall calls attention to the fact that many, actuated by the undying class hatred of Jefferson and the chronic desire to cheapen him in the public estimate, afterwards were heard to say, that "that part of the revision performed by Pendleton could be distinguished by its superior precision." The humor of this lies in the fact that Pendleton did not perform any part of the revision. 
In the distribution made of the work, all of the common law and the British statutes down to the fourth year of James I (1607) - the year of the settlement of Jamestown - including all the subjects I have mentioned, were committed to Mr. Jefferson alone. The brevity and conciseness and succinctness, as well as the clearness of expression of this codification, is remarkable. The whole thing occupied only ninety folio pages. Much of what was contained in the report of recodification was not enacted until later, but that was the size of it, if it had all been enacted at once. Some parts of it, notably the abolition of slavery and some features of the slave code, were never enacted at all, and of his superb educational code, establishing a complete system from the $\mathrm{A}$ B $\mathrm{Cs}$ to the crowning result in a State University, only the elementary school part of the last chapter was then actually transferred to the statute books, and it so amended as to mar its working for years. The criminal code, as reported by Mr. Jefferson, entitled, "A bill for proportioning crimes and punishments in cases heretofore capital," etc., occupied only six pages octavo, or, with all the copious notes and references and the embodiment of the AngloSaxon laws, written in that language and accompanied by his own translation, took up only thirteen pages.

The following language in the preamble of $\mathrm{Mr}$. Jefferson's bill "for proportioning crimes and punishments heretofore capital" is characteristic of the man and of his legal style:-

"And forasmuch as the experience of all ages and countries hath shown, that cruel and sanguinary laws defeat their own purpose, by engaging the benevolence of mankind to withhold prose- 
cutions, to smother testimony, or to listen to it with bias, when, if the punishment were only proportioned to the injury, men would feel it their inclination, as well as their duty, to see the laws observed. For rendering crimes and punishments, therefore, more proportionate to each other, Be it enacted by the General Assembly, that no crimes shall be henceforth punished by deprivation of life or limb, except those hereinafter ordained to be so punished."

Jefferson places the defence of capital punishment upon the only sensible ground that it can rest on, if on any, to wit: that certain criminals are capitally punished for the reason that their existence has become inconsistent with the safety of society. There is no defence for capital punishment on the ground that it reforms. There is little on the ground that it deters others. It is very doubtful if it does. But there is such a thing as a criminal, whose very existence and the propagation of whose kind are inconsistent with the welfare of society. In the Code of Virginia, as he revised it, there was to be no conviction for treason, except upon an overt act.

All this might well be called "The Jefferson Code."

I know of no higher tribute to him as a successful legislator than the following, which I shall quote from Mr. Kean's book, "Thomas Jefferson as a Legislator." He says:-

"Some of the changes were so radical, so novel in the experience of mankind, so far reaching in their effects upon society, so difficult to embody in statutes at once concise, simple and clear, that only those who have had experience either in drafting important laws, or in watching the effects in their administration of important statutory changes, can realize the difficulty of the undertaking and the marvellous skill and foresight with which Mr. Jefferson wrought as a legislator. As an illustration of this, it is worth while, even 
to readers who have no acquaintance with technical law, to consider the Virginia 'statute of descents.' This bill became a law in October, 1785. . . . These rules are (briefly stated) the common law 'canons of descent,' by which English inheritances were governed, and largely are still.

"Now, by Mr. Jefferson's act in Virginia, every one of them at one stroke was swept away. The estate was required to pass in parcenary (that is, in equal shares where a class of heirs come in), first, to the children and their descendants. This rooted up both the preference of males over females and of the oldest male over the other children of both sexes. If there be no child nor the descendant of any, to the father, and if no father, to the mother, brothers and sisters and their descendants. If these all be wanting, the estate is divided into two moieties, one going to the paternal and the other to the maternal kindred," etc.

"Thus every shred of pre-existing (English) law of descents was demolished, and a scheme based on new principles, contradictory to it, was substituted in its place. The act as adopted (and it was adopted precisely as Mr. Jefferson drew it), consists of eighteen clauses and occupies a little over a single page in the Statute Book."

"Now it has not been without definite purpose that so much of the substance of the act has been stated, even at the peril of disgusting the lay-reader. It was needful to illustrate what now follows. Under the provisions of this new act, which subverted and reversed all the rules which had previously existed in the State, all the real estate which has descended in Virginia to the heirs of the generations of a hundred years, has passed to those entitled by these provisions. So precise, so comprehensive and exhaustive, so simple and clear, were the terms in which they were expressed, that in the experience of a completed century but one single doubt as to the construction and effect of any part of it has arisen. That single doubt was resolved by the case of Davis vs. Rowe, 6 Randolph, 355."

Mr. Kean says that as one consequence of the wonderful fairness and clearness of Mr. Jefferson's "statute of descents": "It is much less the rule for persons (in 
Virginia) to make wills, than (as I believe) is the case generally elsewhere." "It is a common remark of men, in whose families no special cause for special provision in case of death exists, that" "the law makes as good a will as they care to have."

Most of these reforms in the direction of adapting laws to republican and democratic institutions were followed, more or less awkwardly, by the other states, though some of the abuses that were abolished in Virginia lingered for years in some of the other states.

Jefferson's purpose in abolishing entail and primogeniture is beautifully expressed by him:-

"To annul this privilege, and, instead of an aristocracy of wealth, of more harm and danger than benefit to society, to make an opening for the aristocracy of virtue and talent, which nature has wisely provided for the direction of the interests of society, and scattered with equal hand through all its conditions, was deemed essential to a well ordered republic."

Jefferson sought to democratize not only political and social, but industrial conditions. He wanted free labor, as much as free worship, or free land, or equal justice or equality in the family and among citizens. Thus it came about that slavery was not compatible with his doctrine. Throughout his entire life he was consistently and persistently opposed to it. It crops out in his "Summary View of the Rights of British America," published in 1775, in his "Notes on Virginia," again in the arraignment of the King for encouraging the slave trade in the Declaration of Independence, as originally drawn by him, and still again in the Declaration, in that assertion - which escaped contemporaneous opposition, because it was regarded by super- 
ficial and cynical critics as "a glittering generality"of the "self evident truth" that "all men are created equal," and "endowed by their Creator with ... liberty." With what force Abraham Lincoln used the Declaration of Independence in his fight against the spread of slavery is well known, and this too after the Continental Congress had struck out of the Declaration every word which was regarded by its members as bearing directly on the subject.

Lincoln said: "All honor to Jefferson - to the man who, in the concrete pressure of a struggle for national independence by a single people, had the coolness, forecast and capacity to introduce into a mere revolutionary document an abstract truth, applicable to all men in all times, and so to embalm it there that today and in all days to come it shall be a rebuke and a stumbling block to the very harbinger of reappearing tyranny and oppression."

It has been sometimes urged that Jefferson was not altogether consistent because he did not emancipate his own slaves. Jefferson was in debt - the debt had come to him with his wife's estate - and neither in his lifetime, nor afterwards, could he have freed his or her slaves from the claims of his creditors. He did set free, by will, his household servants - three or four or five of them, I have forgotten - and in order to do this, he had to beg in his testament of the Legislature of Virginia the ratification of the act.

Jefferson in one of his letters said: "The laws do not permit us to turn them loose, . . . and to commute them for other property [that is, plainly to sell them] is to commit them to those whose usage of them we cannot control." 
What Jefferson meant by saying "the laws do not permit us to turn them loose," in view of Randolph's emancipation of his slaves by will, of young Edward Cole's carrying his off to Illinois and setting them free there, and Professor Wythe and many others setting theirs free, is obviously that the law did not permit an indebted man to deprive his creditors of an assured security for the payment of their debts.

Jefferson was the author of the bill which passed the Virginia Assembly permitting slave owners - when out of debt - to emancipate their slaves. He was also the author of the Virginia bill forbidding further importation of slaves into that State. One of his very last acts while President was a message sent to Congress recommending the enactment of a law prohibiting their importation into any port of the United States, so that the law could take effect upon the first moment that was possible under the Constitution, the Constitution itself having forbidden Congress to make any law upon the subject prior to the year 1808, and not having required it to stop importation of slaves even then. $\mathrm{He}$ had tried in the Continental Congress in 1784 to exclude slavery not merely from the Northwest Territory as was later done, but from all the territories of the United States, "ceded or to be ceded," had lost his motion by the vote of a single State, and when the matter is fully analyzed, really by the vote of a single delegate of a single State, who, if he had been present instead of absent, would have carried the decision the other way.

I have never seen it myself, but his bill, or ordinance, by which slavery was to be prohibited in all the territories is said to be in the archives of the National Capitol 
in Jefferson's handwriting. The language used by him on this subject in 1784, was repeated in the ordinance of $\mathbf{1 7 8 7}$ for the government of the Northwest Territory, and part of it is carried down in the Thirteenth Amendment to the Constitution of the United States.

I haven't space to give it here, but I would ask the reader to peruse Jefferson's letter to Edward Coles, dated August 25, 1814. It expresses more nearly than any other one document his views on slavery, and exhibits that singular mélange of radicalism as to aim, and conservatism as to means, which characterized the man. One part of it, I must quote: "My opinion has ever been that until more can be done for them, we should endeavor with those whom fortune has thrown in our hands, to feed and clothe them well, to protect them from ill-usage, require such reasonable labor only as is performed voluntarily by freemen, and be led by no repugnances to abdicate them, and our duties to them." Then follows the language which I have already quoted: "The laws do not permit us to turn them loose, etc." It was harder to be a good master then, than it was to emancipate a lot of ignorant, and for the most part foolish creatures - welcome nowhere - unable to take care of themselves and with nobody under obligations to take care of them. With an emancipation universal - as it was when it finally came - these difficulties were for the most part obviated, but to turn a whole race free, under conditions such that their labor must be sought and paid for, is a different thing from turning a few free to be unwelcome everywhere as men and impossible as laborers - to be objects of suspicion as "free niggers" and possibly victims 
of kidnapping by rough men and of sale into slavery a half of a thousand miles or more away.

Most of the free states forbade their residence; they did not fit into the system in the slave states.

As Jefferson said later: "We have the wolf by the ears. It is equally difficult to hold him and to turn him loose."

I think one of the best pictures of the difficulties of those whose "consciences bore witness against slavery," but who still owned slaves, and who attempted to relieve themselves of the problem by setting them free, is to be found in Helen Gardener's delightful book, "An Unofficial Patriot." By the way, it contains the best portrayal of Lincoln in our literature.

Jefferson did the best he could, as a practical man. He was one of the kindest masters that ever lived, too lenient for the good of his slaves - so lenient as to put and leave his private business in a deplorable condition - for, after all is said and done, his unwillingness to make his slaves do good work accounts more than any other one thing for the fact that his child was left without a shelter for her head, and that the negroes themselves finally had to be sold, some of them perhaps to bad masters.

Jefferson's ever-initiatory mind, when he had what he thought a beneficent public object in view, is illustrated in a long letter to Jared Sparks, dated February 4,1824 , in which he suggests the consecration of the proceeds of the public lands to the emancipation and deportation of the slaves. In after years, however, after the cotton gin came into general use, any voluntary abolition of slavery became impossible; that is impos- 
sible, unless human nature itself could be changed and this very thing of changing human nature is the only thing impossible for the statesman. It must come of itself, after long reaches of time.

It is to be said for the slaveholders of the South, and for the non-slaveholding classes of the South, who were just as intense in their devotion to the Southern cause, that, although there was slavery among them, it was, as a system, the least onerous, the least cruel, and the kindliest slavery the earth ever witnessed.

My early boyhood was spent on a plantation of 150 slaves. I was eleven years of age when the war closed. I remember only three plantation punishments: One a man whipped for stealing, one a woman whipped for general and dangerous prostitution, and the other was that of a man, who was kept on bread and water for two weeks, because he had in a mutual fray killed his brother. The last finally met with the penalty unprecedented on that place - which he dreaded most, and tearfully attempted to escape - sale.

I leave this plain narrative without comment. Nor do I pretend that there were no exceptions to the almost universal kindly usage - almost patriarchal in its character - on which I have slightly raised the curtain. But, in the Chancel of God, where all acts and all motives are known, the slaveholders of the South will not stand least prepared amongst men to receive Divine justice, or Divine mercy. Much of their heroism upon the battle-field, indeed, grew out of the fact that they had been held up to the world's hatred, as cruel and selfish and autocratic, when they knew that they were none of these. They were fighting 
personal insult as much as anything else. Certainly no class enjoying by law special caste privilege, or any class subjected by their situation to such grave temptations, ever behaved so well.

The first sentence of Jefferson's bill "Concerning Slaves" - that is, the bill abolishing the importation of slaves into Virginia, was in these words:-

"That no persons shall henceforth be slaves within this Commonwealth, except such as were so on the first day of this present session of Assembly, and the descendants of the females of them. Slaves which shall hereafter be brought into this Commonwealth, and kept therein one year, or so long at different times as shall amount to one year, shall be free."

If each State had imitated this statute, slavery must have died out in the border States, and the race problem, even in the cotton States, owing to the consequent comparative paucity in numbers of Africans, would never have been the stupendous thing it now is.

Professor Andrew D. White, "Jefferson and Slavery," in the Atlantic Monthly of January, 1862, says:-

"Logic forced him to pass from the attack on aristocracy to the attack on slavery, just as logic forces the Confederate oligarchs of today to pass from the defence of slavery to the defence of aristocracy."

Remember, this was written in 1862, and therefore considering the heated feelings of war times, the son of a Confederate soldier can forgive Professor White for referring to his forefathers as "oligarchs"; which they by no means were. But it is none the less true that the defence of slavery did logically compel to a certain extent the defence of caste, for it was itself a form of 
caste and class privilege. But as Thomas Carlyle said: "I thank God men are not logical."

Professor White quotes these utterances from Jefferson, which I shall re-quote. Remember, Jefferson is addressing his brother slaveholders of Virginia:-

"When arguing for ourselves, we lay it down as fundamental, that laws, to be just, must give reciprocation of right - that without this, they are mere arbitrary rules of conduct, founded in force, and not in conscience; and it is a problem which I give to the master to solve, whether the religious precepts against the violation of property were not framed for him as well as his slave - and whether the slave may not as justifiably take a little from one who has taken all from him as a man may slay one who would slay him."'

"Can the liberties of a nation be thought secure, when we have removed their only firm basis - a conviction in the minds of the people that their liberties are the gifts of God, that they are not to be violated but with His wrath? . . . The Almighty has no attribute, which can take side with us in such a contest."

"What a stupendous, what an incomprehensible machine is man - who can endure toil, famine, stripes, imprisonment, and death itself, in vindication of his own liberty, and, in the next moment, be deaf to all those motives whose power supported him through his trial, and inflict on his fellow men a bondage one hour of which is fraught with more misery than ages of that which he rose in rebellion to oppose?".

"The hour of emancipation is advancing in the march of time. It will come; and whether brought on by the generous energy of our own minds or by the bloody process of St. Domingo, . . . is a leaf of our history not yet turned over."

If the war had not come, and the slaves been freed as a "war measure," and if - there being no power under the Constitution for Congress to interfere with slavery 
in the States - slavery had continued for another half century or so, the negro population growing in comparison with the whites, as it did under slavery conditions - so favorable to their birth rate and unfavorable to their death rate - would not the scenes of San Domingo have been some day necessarily reenacted in the Southern cotton States?

Jefferson's enduring influence in every word he uttered is shown by the fact that during the War Between the States, Andrew D. White, in this very article, quoted in favor of the abolition of slavery, as a "war measure," what Jefferson said, when Cornwallis had carried his negroes off to die of smallpox and then deserted them stricken and dying: "Had this been to give them their freedom, he would have done right." This is quoted against Jefferson's own kith and kin, against the South that he loved so dearly, against Virginia that he almost worshipped. But it must be confessed that what Jefferson said was a logos, just as is the phrase of the Declaration of Independence, "All men are created equal and endowed," etc. In the latter case, I have no doubt that Jefferson intended it to be as a leaven, and that he saw, long down the aisle of time, the day when that leaven must work.

Jefferson's own words in connection with his desire to procure the emancipation and deportation of slaves, better express his view than any explanation of them:-

"It is still in our power to direct the progress of emancipation and deportation, peaceably, and in such slow degree, as that the evil will wear off insensibly, and their place be, pari passu, filled up by free white laborers. If, on the contrary, it is left to force itself on, human nature must shudder at the prospect held up." 
Later, Mr. Jefferson in his "Memoir" uses this language in connection with the same subject:-

"But it was found that the public mind would not yet bear the proposition, nor will it bear it even at this day. Yet the day is not distant when it must bear and adopt it, or worse will follow. Nothing is more certainly written in the book of fate than that these people are to be free. Nor is it less certain that the two races, equally free, cannot live in the same government. Nature, habit, opinion, have drawn indelible lines of distinction between them."

If our Southern ancestry could have "borne" the proposition early enough, what a deluge of blood, what a wealth of women's tears, what devastations of the land, and what waste in treasures had been spared us! And if your Northern forefathers had only remembered the balance of what Jefferson wrote and knew so well, or if they could, in the nature of things, have known it; namely, that the two races cannot live equals politically and socially, in the same government, because "nature, habit and opinion have drawn indelible lines of distinction between them," how much of the criminalities, follies, mad saturnalia and corruption of reconstruction, how much of the great "Fool's Errand," as it is so well designated by one who calls himself "one of the fools," would have been spared us as a nation!

I know of nothing showing the prescient wisdom of one man, more than these few lines just quoted from Mr. Jefferson show his. In this, as in many other instances, it has seemed to me that the man had an intuitive, and not merely a reasoned, insight into the future. What would we not have been by now had we never been cursed with slavery, with the irrepressible, bloody and wasteful conflict growing out of it, and with 
the almost unavoidable pendente bello and post bellum federal and industrial consolidation, all leading to the casting off of the ship for so long a time from the old Jeffersonian moorings! It must be confessed that the running together of partisan interest and of slave interest made the party which Jefferson founded to cease for a time to be Jeffersonian - made it a defender of aristocracy, as well as of slavery in the South. It seems restored to its old course again. God grant that the verisimilitude prove a verity!

The plan of emancipation and deportation, which Jefferson drew up - intended to be offered as an amendment to the slave code - as reported by the law revisers, contemplated not only the freedom of all slaves born after a certain date, but their apprenticeship to some trade, until reaching a certain age, and then their deportation to some territory to be bought for them, and an advancement of tools of husbandry and of provisions sufficient for them to support themselves, until a crop had been made on land given them.

Lincoln, like Jefferson, recognized inherent differences between the two races, and regarded the blacks as essentially inferior. In other words, neither was ever free of that which most people call "race prejudice," but which I think ought to be called "race knowledge."

It will be remembered that when Jefferson resigned from the Continental Congress to go to Virginia in order to make sure of democratic reforms, one reason he gave for undertaking it at that time was this: "The shackles which shall not be knocked off at the conclusion of this war will remain on us long, will be made 
heavier and heavier, till our rights shall revive or expire in a convulsion." Thus early he foresaw the great American Counter Revolution.

He was so convinced that this great work of "adapting the laws to republican institutions," was needful, if the fruit of our war for independence was to be anything more than a mere change of buntings, that the trappings of office on the one side could not tempt, nor the hatred of the beneficiaries of special privilege, on the other hand, deter him.

Speaking of the purpose of his revision work, he says in his "Memoir":-

"I considered four of these bills passed or reported, as forming a system by which every fibre would be eradicated of ancient or future aristocracy, and a foundation laid for a government truly republican. (1) The repeal of the laws of entail would prevent the accumulation and perpetuation of wealth in select families, and preserve the soil of the country from being daily more and more absorbed in mortmain. (2) The abolition of primogeniture, and the equal partition of inheritances, removed the feudal and unnatural distinctions which made one member of every family rich and all the rest poor. (3) The restoration of the rights of conscience, relieved the people from taxation for the support of a religion not theirs; for the establishment was truly the religion of the rich, the dissenting sects being entirely composed of the less wealthy people; and (4) These, by the bill for general education, would be qualified to understand their rights, to maintain them, and to exercise with intelligence their parts in self-government. And all this would be effected without the violation of a single natural right of any one individual citizen."

The last sentence is especially characteristic of the "Conservative Reformer." A reformer, yes, that is the substantive - the main thing - but conservative in method - almost noiseless in approach. Later Jeffer- 
son had reason to believe that reformation would have to go yet deeper at some future time in order to prevent that undue accumulation of wealth in the hands of a few people - so destructive of the spirit of free institutions - and in one of his letters - I do not recall to whom - he said that when that day should come, the abolition of primogeniture and entail would have to be followed by "a limitation of the statutory privilege" of bequest, devise and inheritance, as to the amounts which could be left by any one person, to any one person, or purpose. He was prescient and far-seeing in this, too, and to it we must come. It will also be only the limitation of "a statutory privilege," not "the violation of a single natural right" of a single citizen.

Jefferson well says, that it is intolerable that the skeleton fingers of the dead shall forever reach from their graves to control the destinies of the living to their detriment. And yet further, in a letter he wrote from France, being, as he designated it, a "train of reflections" on "the unequal division of property," caused by finding people "without land to work or work to do" in a part of France, where "enormous holdings," in the hands of great lords, "some of them" waited on by "200 domestics," were "devoted to game" - thus placing the proprietors there above the necessity or incentive of improving, or even of cultivating the land - he says - after recognizing that equal division is impracticable and undesirable: "but legislators cannot invent too many devices for subdividing property, only taking care to let those subdivisions go hand in hand with the natural affections of the human mind." Then he recommends as a first step for France what she sub- 
sequently adopted, and what he had already partially accomplished in Virginia: Descent to all the children if none, to all the brothers and sisters - or in default of those to "other relatives in an equal degree." "Another means of a fairer distribution," he suggests, "is to exempt all real property below a certain value from taxation and graduate the tax on the rest in proportion to the magnitude of the holding in geometrical progression." He adds: "The earth is given as common stock for man to live and labor on. It is too soon yet in our country to say that every man, who cannot find employment, but who can find uncultivated land, shall be at liberty to cultivate it, paying a moderate rent," but "not too soon" to make it a point, that "as few families as possible shall be without a little portion of land" - "Small landholders are the most precious part of the State."

Leicester Ford finds in all this a demonstration of "French influence," and, I presume, much "horrid radicalism"! I confess I see nothing French in it, except a protest against French conditions and the fact that it happened to be written in France, after a Laurence-Sterne-sort of a meeting with a poor old French woman. I confess, too, that, if the recommendations reached at the end of this "train of reflections" be radical, they seem to me none the less wise.

But to return to our sheep: He took his seat in the Virginia House of Delegates on October 7th. Five days after that, in such a hurry was he to strike while the iron was hot, he took his first steps towards effecting the gigantic reforms to which I have referred. To use his own language, he thought it well, first to try 
"the strength of the general pulse of reformation," by attacking the salient "vicious points," "prominent in character and principle."

On October 12th, he moved and received leave to bring in a bill entitled, a bill "To enable tenants in taille to convey their lands in fee simple," and on the same day received leave to bring in a bill "For a revision of the laws." He was doing his work quickly, because on the 14th he reported back the first bill. The enormity of this revolution and its influence upon the economic condition and the social life of Virginia, can scarcely be exaggerated. All over the State, but preëminently on "The Eastern Shore" and in the lower counties, the land had been gathered into great estates, held by the law of entail from generation to generation in the same family. Moreover, by the law of primogeniture, they descended to the oldest son of the family. These two laws together had produced the same result, which may be now viewed in Great Britain, only the result in Virginia was still more pronounced, if anything, because the law of entail there carried slaves as well as land. As a consequence, the social structure was essentially aristocratic, producing, on the one hand, a class of great landlords, living in luxury, sometimes in idleness, though, be it said to their credit, for the most part, usefully, and in the spirit of noblesse oblige. But The Few controlled in politics, in society, and in every other way. No worthier aristocracy, upon the whole, than that of Colonial Virginia, ever existed, none ever devoted itself more unselfishly to the public service, none ever cared less about pelf; but it was none the less an aris- 
tocracy, and, as such, was antagonistic to every political theory of young Jefferson, middle-aged Jefferson, and old Jefferson. A class like this must, in the nature of things, exercise more influence than any equal number of equally able men not possessing their artificial advantages - of station, education, social life, wealth; and must in the nature of things exercise it as a class. The governmental structure necessarily rests upon the social and family structure.

The Lees, the Randolphs, the Pendletons, the Nelsons, the Pages, the Carters, the Careys; a hundred names will suggest themselves at once, illustrating the justice of any possible tribute to the old Virginia aristocracy, but the contemplation of them and their services is the bright side of the shield.

Jefferson's doctrines, as Randall says, were "hard and unpalatable" to many of this class, whom Jefferson, in a pet, once called "the nurselings of luxury," and some of whom he designated as being "monomaniacs on the subject of family importance." For years afterwards it was fashionable to dwell sentimentally upon "the decadence of Virginia," and to attribute this to "the decadence of the great families," and this, in turn, to Thomas Jefferson's "leveling principles." Randolph of Roanoke, after he became sour, indulged in much of this sort of drivelling.

It was not the abolition of special privileges, which held Virginia back; it was the failure to go far enough with the good work and abolish slavery and deport the slaves, just as it is the presence of an alien, unassimilable and improvident race, constituting industrially an inefficient labor, and socially a constant irritant, which is today the South's sole drawback. 
We can all now realize what an effect the equality of inheritance has upon the framework of society; how it tears down an artificial and superficial, though fairappearing structure, and substitutes for it another more enduring, and in every way better adapted to secure the liberty and happiness and independence of man.

In his own State, and in the South generally, the abolition of primogeniture and entail has thus far secured a fair distribution of wealth, but a worse thing than primogeniture is taking its place in some of the Northern States - especially in New York - where it has become a fad with some of the rich families to leave by will nearly all of their stupendous estates, not to the oldest son, who might possibly feel that he had enough money and "go in for" something else, but to that one of the sons, who comes nearest resembling the founder of the family fortune in his greed for money, and in his capacity for making it - in short, to the best "money-grubber" in the stock.

The peculiar thing is that Jefferson procured the passage of these "laws striking at the ascendency and domination of great, respectable and respected classes" by an appeal to the reason of a body in which those classes themselves were numerously represented, and of which classes Jefferson himself was a member, for he was a holder of extensive lands and an owner of very many slaves, and in his own family an eldest son. But he did not secure their passage without a fight - a fight not as acrimonious as it would have been, if anybody but Jefferson had been the advocate of the reforms, nor if the struggle had taken place elsewhere than in Virginia, where it was a tradition that political oppo- 
nents, however divergent their views, must in public be personally courteous to one another. Men of more than respectable talents, however - among them the Pendletons and Nicholases - met him in the breach. When frontal attack failed, they resorted to attacks on the flank. For example, when the law to abolish entails was proposed, Mr. Pendleton, desiring to emasculate it, moved an amendment that the holders of such property might convey it in fee simple, "if they chose to do so," and came within a few votes of securing the passage of the amendment!

Proceeding with his work of reformation, on October 14th, he procured leave to bring in a bill for the naturalization of foreigners, and reported the bill upon this subject on the same day. This bill is remarkable, not only because it outlines an American policy towards those seeking our shores, which became afterwards permanent, except for a short interruption by the Federalists during alien and sedition law times and a brief menace during Know-Nothing days, but it is remarkable as being the first public legislative denial of the doctrine of indefeasible allegiance. To this I have referred. Both these, it may be safely asserted, have become for us permanent and irrevocable national policies.

Among other then notable and far-reaching things, he subjected land, just like other property, to the payment of debts. He made it a fluid asset. This was very important in connection with the work of democratizing. You cannot completely free the man, unless you free the land. Man - the worker, land - the fulcrum - these two, in ultimate analysis, are all. 
Against the proposed abolition of primogeniture, Pendleton made a strong stand in committee in behalf of his class, and when he found a majority against him, resorted to a ruse, by proposing to adopt "the Hebrew principle," that is, to give the oldest son a double portion. Jefferson, quaintly, but decisively, answered, that "if the eldest son could eat twice as much, or do double work, it might be a natural evidence of his right to inherit a double portion; but being on a par in his powers and wants, with his brothers and sisters, he should be on a par also in the partition of the patrimony." The committee agreed with him.

These laws exerted for all time their democratizing influence over the people of Virginia, and, by their example which was imitated elsewhere, a beneficent influence over all America, but especially in the new States created out of the old Territory of Virginia, where he and his ideas were all his life intensely popular.

John Esten Cooke, in his "History of Virginia," says:-

"After 1800, Virginia gradually assumed a new physiognomy. Dress and manners underwent a change. The aristocratic planter, with his powder and silk stockings, gave place to the democratic citizen, with his plain clothes and plain manners. The theories of Jefferson were adopted as the rule of society. . . . Class distinctions were ignored as a remnant of social superstition."

On the 13th of August, 1777, Jefferson wrote to Franklin as follows:-

"With respect to the State of Virginia, ... the people seem to have laid aside the monarchical and taken up the republican government, with as much ease as would have attended their throwing off an old and putting on a new suit of clothes. Not a 
single throe has attended this important transformation. A half-dozen aristocratical gentlemen, agonizing under the loss of preeminence, have sometimes ventured their sarcasms on our political metamorphosis."

In one graphic sentence, Thomas E. Watson, in his "Life and Times of Jefferson," gives the effect of Jefferson's work in democratizing Virginia institutions: "He unfettered the land, changed the tenure from fee tail to fee simple, made the soil democratic, and made the law to correspond. ... Mind and tongue were unfettered. Religious liberty came to all." Truly "a State made over," and virtually by one man, whom shallow-pates have called a "doctrinaire!" That old quotation comes to my mind: "They said he was a dreamer, but his dreams came true."

What is a doctrinaire?

Burke, the prince of rhetoricians, says of Chatham, the elder Pitt: "For a wise man he seemed to me at that time to be too much governed by general maxims." But history records practically nothing left by Burke to mark his impress on institutions and history, while she records Chatham as an empire builder.

Yet, let us not give Jefferson all the credit. Old Virginia had the heart and head to follow him in every respect, except concerning slavery; to embrace a democracy of equal rights, equal opportunities without legal or artificial privileges, and thus democratic has she remained - "so shedding light" that all good States may imitate her example.

Jefferson always contended that despite its admirable town-government system, the governing spirit of Federalist New England was not genuinely democratic. 
This has "amused" some of the late writers, who assume to wear the old Federalist mantle, under the impression that it sets them aside as something "superior!"

Mr. C. Edward Merriam, of the University of Chicago, has written a very interesting book entitled, "American Political Theories," published by the Macmillan Company in 1903, the perusal of which, under this head, I recommend to the reader. Among other things which he makes perfectly plain is the fact that the system of government advocated by the early Puritans was based upon neither equality nor democracy; it was a theocratic government, with pretty nearly all the power directedly or indirectly wielded by the clergy - so much so that only church members could become "freemen;" that is, a part of the governing community. This was the case by law in Massachusetts and New Haven, and by actual practice in Plymouth and Connecticut. As he says, it was Roger Williams, not the Puritans, who stood for democracy, in New England. He taught limiting the activity of the state to what were called "breaches of the second table," a new phrase to me, when I struck it. The first four commandments were called the first table, because they related to the duty of man to God, and the last six were called the second table, because they related to the duties of man to man. In essential basic character, Roger Williams' view of the limits of the state in the affairs of men is not unlike that of Thomas Jefferson.

Merriam cites that John Cotton in 1644 denounced democracy as "the meanest and worst of all forms of 
government," and that as late as 1764 in Massachusetts Bay the proposition to establish aristocracy, as a form of government, was rejected, only because it involved "the abandonment of the requirement of church membership for the exercise of suffrage!" (Italics always mine.)

Merriam adds that the "Puritans did not preach or practice religious toleration, nor did they become enthusiastic about the inherent rights of man." The equality which they believed in was spiritual equality; that is, equality among the saints - the elect. Of course, in this connection, the distinction between the Pilgrim Fathers and the Puritans must be kept in mind; they are generally confused. The practice and theory of the former were perfectly democratic and much more conducive to equality of citizens in the state. The political ideas of the Quakers were much more nearly those which were finally stamped as American and national by the adoption of the Declaration of Independence, and much more nearly like those which were advocated by Roger Williams and Jefferson, than were those of the early settlers in New England. William Penn's definition of free government is not a bad one. It is this: "Any government is free to the people under it . . . where the laws rule and the people are a party to those laws." Compare this with Jefferson's definition of a "Pure Republic," which see later. The two constitute not a bad definition of the theory of the true, not the play-acting, "progressives" of today.

Mr. Jefferson, when he left Congress and went home to be elected to the House of Burgesses, had said, that he did it because the "laboring oar was really at home." 
It was eminently in keeping with all of his opinions and all of his future life, that he should have begun the work of democratizing American institutions, educationally and socially and industrially, in the State raising a standard for the other States - because the State was, as he later expressed it, the "surest safeguard of republican institutions."

\section{AN APOSTLE OF LOCAL SELF-GOVERNMENT}

Jefferson has long been regarded as the apostle of local self-government. In his first inaugural address, in all his state papers, and in all of his letters, where there was any relevancy to the question, and in the Kentucky Resolutions, his apostleship is displayed; but for the most part, people have only the idea of States' Rights in their minds in connection with his position. Jefferson went further than that. Notwithstanding the Kentucky Resolutions, which were in content mainly, and in intent altogether, a State protest only, two men were never in all history really further apart than he and John C. Calhoun. He was very much enamoured with the old Saxon Communal Government, and he became early in life, and continued to his death, enamoured with the New England Township System, a system which brings the direct government of the people, upon a small scale, into more perfect operation than any other institution in America.

On May 26, 1810, after he had retired from the Presidency, he said in a letter to Governor. Tyler:-

"I have indeed two great measures at heart, without which no republic can maintain itself in strength. 1. That of general education, to enable every man to judge for himself what will secure or endanger his freedom. 2. To divide every county into hundreds, 
of such size that all the children of each will be within a central school in it. . . . These little republics would be the main strength of the great one. We owe to them the vigor given to our revolution in its commencement in the Eastern States."

\section{To Joseph C. Cabell, on January 31, 1814, he writes:-}

"There are two subjects, indeed, which I claim a right to further as long as I breathe - the public education and the subdivision of counties into wards. I consider the continuance of republican government, as absolutely hanging on these two hooks."

In another letter he says, to the same correspondent: "My friend, the way to have good and safe government is not to trust it all to one, but to divide it among the many, distributing to every one exactly the functions he is competent to." Then follows his subdivision, beginning with the national government and its proper functions, continuing through the state governments and a general description of what should concern them, to the counties, and then the "wards," as he called them, or "townships," as they were called in New England. Of them he says:-

"The elementary republics of these wards, the county republics, the State republics, and the republic of the Union, would form a gradation of authorities, standing each on the basis of law, holding every one its delegated share of powers, and constituting truly a system of fundamental balances and checks. . . . Where every man is a sharer in the direction of his ward republic, or of some of the higher ones, and feels that he is a participator in the government of affairs, not merely at an election one day in the year, but every day; ... he will let the heart be torn out of his body sooner than his power be wrested from him by a Caesar or a Bonaparte.",

\section{Then he exclaims:-}

"How powerfully did we feel the energy of this organization in the case of the Embargo? I felt the foundations of the government 
shaken under my feet by the New England township . . . and, although the whole of the other States were known to be in favor of the measure, yet, the organization of this little selfish minority enabled it to override the Union. . . . As Cato once concluded every speech with the words, 'Carthago delenda est,' so do I every opinion with the injunction, 'divide the counties into wards.' Begin them only for a single purpose, they will soon show for what others they are the best instruments."

\section{Again, to Samuel Kercheval, on July 12, 1816:-}

"These wards, called townships in New England, are the vital principle of their government, and have proved themselves the wisest invention ever devised by the wit of men, for the perfect exercise of self-government, and for its preservation."

Jefferson's definition of "a pure republic" is this: "A government by the citizens in mass, acting directly and personally, according to the rules established by the majority." (See Penn's definition on a previous page.) He acknowledges that these "pure republics" can exist only on areas so small that all citizens may readily meet together.

With regard to local self-government, in another place, he says: -

"Our country is too large to have all its affairs directed by a single government. Public servants at such a distance, and from under the eye of their constituents, must, from the circumstance of distance, be unable to administer and overlook all the details necessary for the good government of the citizens, and the same circumstance, by rendering detection impossible to their constituents, will invite the public servants to corruption, plunder and waste. . . . You have seen the practices by which the public servants have been able to cover their conduct, or, where that could not be done, the delusions by which they have varnished it for the eye of their constituents. What an augmentation of the field for jobbing, speculating, 
plundering, office building and office hunting would be produced by an assumption of all the state powers into the hands of the general government.".

Whether the States are to remain indestructible and whether the precious blessing of local self-government upon smaller areas is to be perpetuated, depends upon the degree of concentration of governmental power at Washington. If it is carried too far, of course, the cords some day must snap, and if they do, one of "the two hooks" upon which our destinies hang will have disappeared, "the balance" will be lost, and no man is wise enough to foresee the ultimate result. The real balance in this Government is that between the States and the counties and the townships, on one side, and the Federal Government, on the other. These "lesser republics" have jurisdiction over nine-tenths of the questions which concern the individual in his daily life. It is even of more importance that the government of them should be wise and pure and free and enlightened, than it is that the National Government should be so. It is their not being so, which gives pretext for Federal usurpation. The ship has thus far weathered the gale, though with some broken spars and shredded sails.

Montesquieu had written - and Montesquieu was a name held in high reverence in that day by all except Thomas Jefferson - that a republic was adapted only for a small territory, but Jefferson's conviction was precisely the contrary, if only it were a Federal Republic of limited, delegated powers. "A Republic of Republics!" That is the name which Sage, of New Orleans, in a book by that title gave to our dual government. 
If it had gone further and read, "A Republic of Republics and of Lesser Republics" - carrying the mind down to the county and township republics, with their direct participation by all the people in democratic assemblies - it would have been thoroughly descriptive of Jefferson's ideal.

Virginia had adopted a written constitution in 1776. It was adopted at a time when patriots were trying to get together, and when the main object in view was to put some sort of State government upon a legal footing, to take the place of the patriotic but irresponsible revolutionary committees. There were some undemocratic features in it needing revision. Long afterwards, Samuel Kercheval wrote some letters on the subject and enclosed them to Jefferson, asking his advice. There is much of Jeffersonianism in Jefferson's reply, and of the sort which has exerted a permanent influence on our State institutions. In many respects, it is worthy to stand side by side with "The Summary View," the great "Declaration of Independence," the platform letter to Elbridge Gerry in 1800, and the "First Inaugural," as an exponent of Americanism.

This letter appears in full as Appendix 29 to be found in the third volume of Randall's "Life of Jefferson," page 647. It was dated July 12, 1816. Excerpts from which are as follows:-

"In truth, the abuses of monarchy had so much filled all the space of our political contemplation, that we imagined everything republican, which was not monarchy. We had not yet penetrated to the mother principle that 'governments are republican only in proportion as they embody the will of their people, and execute it.' Hence, our first constitutions had really no leading principle in them. But experience and reflection have but more and more 
confirmed me in the particular importance of the equal representation then proposed.

"In the Legislature" (of Virginia) "the House of Representatives is chosen by less than half the people, and not at all in proportion to those who do choose. The Senators are still more disproportionate, and for long terms of irresponsibility. In the Executive, the Governor is entirely independent of the choice of the people, and of their control; his council equally so, and at best but a fifth wheel to a wagon. In the Judiciary the judges of the highest courts are dependent on none but themselves. In England, where judges were named and removable at the will of an hereditary executive, from which branch most misrule was feared and has flowed, it was a great point gained, by fixing them for life, to make them independent of the executive. But in a government founded on the public will, this principle operates in an opposite direction, and against that will. There, too, they were still removable on a concurrence of the executive and legislative branches. But we have made them independent of the nation itself."

This utterance, and what follows about judges, with its cool, limpid reasoning, was and is of far-reaching influence.

In Jefferson's day all State judges, as far as I have learned, except in Connecticut, were appointed. In the twenties he urged their election for fixed terms in Virginia, and cited the success of the experiment in Connecticut. By the time the Democracy had developed itself further under Jackson, they were nearly everywhere elected, and life tenure was abolished everywhere, except with the Federal Judiciary. Thus all three branches of the government became democratized.

Of the Revolutionary constitutions, very few, if any, were submitted to the people, they being adopted by conventions alone. 
Beginning with "the word" - under Jefferson, and culminating with the deed under Jackson, constitutions began everywhere to be submitted to the people for their ratification; that is, nearly everywhere. Some few very conservative States never did submit them. No constitution of Mississippi, for example, except one, was ever submitted to the people, the people seeming to think that they can get a wiser, better fundamental law, if they elect the very best men to constitute a constitutional convention, and leave them with plenary power. This was all a growth out of Mr. Jefferson's doctrine that he wanted "frequent recurrence to fundamental principles."

Recurring in this letter to his favorite scheme for the complete democratization of Virginia - dividing the counties into wards and giving them direct selfgovernment to a certain extent similar to the New England township system - he says:-

"The organization of our county administrations may be thought more difficult. But follow principle, and the knot unties itself. Divide the counties into wards of such size as that every citizen can attend when called on, and act in person. Ascribe to them the government of their wards in all things relating to themselves exclusively. A justice, chosen by themselves, in each; a constable, a military company, a patrol, a school; the care of their own poor, their own portion of the public roads, etc. . . . These wards, called townships in New England, are the vital principles of their governments, and have proved themselves the wisest invention ever devised by the wit of man for the perfect exercise of self-government, and for its preservation. We should thus marshal out government into, 1. The general federal republic, for all concerns foreign and federal; 2 . That of the state, for what relates to our own citizens exclusively; 3 . The county republics, for the duties and concerns of the county; and, 4. The ward republics, for the small, and yet numerous 
and interesting concerns of the neighborhood; and in government, as well as in every other business of life, it is by division and subdivision of duties alone, that all matters, great and small, can be managed to perfection. And the whole is cemented by giving to every citizen, personally, a part in the administration of the public affairs."

After this, he sums up the whole situation and expresses the philosophy underlying it:-

"The sum of these amendments is: 1 . General suffrage; 2. Equal representation in the Legislature; 3. Judges elected or amovable; 5. Justices, jurors" (evidently grand jurors) "and sheriffs elective; 6. Ward divisions; and, 7. Periodical amendments of the Constitution.

"I have thrown out those, as loose heads of amendment for consideration and correction; and their object is to secure self-government by the republicanism of our constitution, as well as by the spirit of the people; and to nourish and perpetuate that spirit. I am not among those who fear the people. They, and not the rich, are our dependence for continued freedom. And to preserve their independence, we must not let our rulers load us with perpetual debt. We must make our election between economy and liberty, or profusion and servitude."

In this last sentence is the doctrine of "Jeffersonian simplicity."

Note the summing up and remember how - gradually beginning the work then and substantially completing it under Andrew Jackson - his political disciples pursued his instructions in nearly all the States, and in every case (except the election of grand jurors and (7), the last), to a successful consummation. He came afterwards, as I shall show later in my lecture on Educational Influence, to modify his views on the suffrage, to the extent, of desiring an educational, or reading and writing, qualification. This is being gradually adopted, and will be universally. 
Dr. Grigsby says in his discourses on the Virginia Convention of 1776 : -

"The first Constitution of Virginia withstood, for nearly forty years, his (Jefferson's) attacks in the Notes; but when he threw his thoughts into the shape of a letter to Kercheval, the fate of that instrument was sealed. The phrases of that letter were at once stereotyped in the public voice; and it was amusing to observe on the court green, and in debate, how these phrases passed current with men, who had never seen or heard of the letter, and who believed that they were clothing their own thoughts in their own words."

And this summary, too, by Watson is well worth reading and well worth remembering:-

"The ink of the Declaration of Independence was hardly dry when this same 'timid' Jefferson hurried to Virginia, challenged the proud, strong aristocracy of the Old Dominion to the field, and unhorsed it in fair fight. Then he accomplished what French Revolutionists found it hard to do, and what Mr. Gladstone found it so hard to do in Ireland, and what no man has been able to do in England to this day - he disestablished the State church.

"Not only that! He told the whites they ought to free the blacks; and told the rich they ought to tax themselves to educate the poor." . . .

"Yet so scholarly a writer as Henry Cabot Lodge, makes 'timidity' a salient feature of Jefferson's character; and Mr. Roosevelt continually repeats that he was 'weak and vacillating.'"

What I am now about to quote from Jefferson, I select to repeat and emphasize that it was not alone the state governments, but the county and town governments, within their several spheres, for the full vigor of which he always contended:- 
"But the true barriers of liberty in this country are our state governments; and the wisest conservative power ever contrived by man is that of which our revolution and present government found us possessed. Seventeen distinct states, amalgamated into one, as to their foreign concerns, but single and independent as to their internal administration, regularly organized with a legislature and governor resting on the choice of the people, and enlightened by a free press, can never be so fascinated by the arts of one man, as to submit voluntarily to his usurpation. Nor can they be constrained to it by any force he can possess. While they may paralyze the single state in which it happens to be encamped, sixteen others, spread over a country of two thousand miles diameter, rise up on every side, ready organized for deliberation by a constitutional legislature, and for action by their governor, constitutionally the commander of the militia of the state - that is to say, of every man in it able to bear arms - and that militia, too, regularly formed into regiments and battalions, into infantry, cavalry and artillery, trained under officers, general and subordinate, legally appointed, always in readiness, and to whom they are already in habits of obedience. The republican government of France was lost without a struggle, because the party of 'un et indivisible' had prevailed, no provincial organizations existed to which the people might rally, under authority of the laws, the seats of the directory were virtually vacant, and a small force was sufficient to turn the legislature out of their chamber, and to salute its leader chief of the nation."

In "Jefferson and His Political Philosophy," by Mary Plate Parmelee, she says of Jefferson's great and restless mind, that "it was a laboratory and not a storehouse," and that, "He believed that the ideal government should be framed not so much to restrain the popular will as to express it; not to obstruct, but to execute it."

We can only wonder that the hatred of Jefferson was not greater. He offended in turn each entrenched class. Take that one expression of his: "I tremble for 


\section{PERMANENT INFLUENCE OF JEFFERSON}

my country when I think of the negro and know that God is just." These are words uttered by Thomas Jefferson in Virginia - by a slaveholder in the midst of slaveholders - and not by Lincoln in Illinois, nor by Garrison or Sumner in Massachusetts, where they would have been popular! 


\section{CHAPTER IV}

\section{JEFFERSON'S INFLUENCE AS A DIPLOMAT}

There is no use for my purpose in detailing dates and circumstances of Jefferson's being sent to France. $\mathrm{He}$ is there first with two colleagues, John Adams and Benjamin Franklin, as Envoys Extraordinary, and subsequently alone as Minister to France. He was not only lucky in having succeeded Mr. Franklin as Minister, but he was lucky in this: that America was then itself, as Franklin was, a sort of fad in Paris with litterateurs, and even with courtiers.

There was not much for Jefferson to do in France of weighty concern to our prosperity. He did obtain the admission of our products on favorable terms, as compared with those of other nations, and a mitigation of the Government tobacco monopoly. In fact, considering how the ghost of the mercantile theory still had its fingers around the throats of all the ruling spirits in nearly every nation, he did a good deal. He gave a sensible stimulus to our policy of Reciprocity. In his diplomatic correspondence he shows himself fully in possession of those economical principles the soundness of which Adam Smith was demonstrating.

He writes to the French Premier that France "could not expect America to come to her to purchase, when she did not take American commodities in return," thus impressing the great economical truth, that, after 


\section{PERMANENT INFLUENCE OF JEFFERSON}

all, commodities are somehow, somewhere, paid for with other commodities.

Finally, before he left he had a battle royal with the protective system, which was shutting the ports of France against food when Frenchmen were dying for the lack of it; "and spent his last days, even his last hours, in Paris, in trying to persuade the Ministry to permit the importation of salted provisions from the United States," and failed! Parton epitomizes the interview delightfully. "Salt beef," objected the Count de Montmorin, "will give the people scurvy." "No," replied Jefferson, "we eat it in America and we don't have the scurvy." "The salt tax will fall off," said the Minister. Jefferson could not deny that it might a little; but, on the other hand, "it would relieve the Government from the necessity of keeping the price of bread below its value." "But," resumed the Count, "the people of France will not buy salt meat." "Then," replied Jefferson, "the merchants won't import it, and no harm will be done." "And you cannot make a good soup out of it," urged the Count. "True," said Jefferson, "but it gives a delightful flavor to vegetables. Besides it will cost only half the price of fresh meat."

Ridiculous, isn't it? But this last year our people were paying three prices for Irish potatoes, and yet Congress could not be prevailed upon to suspend the import duty!

Nothing, however, done by Jefferson in France as Envoy or as Minister can be said to have permanently affected our International Relations unless it be the so-called Model Treaty, which Franklin, Adams and 
he put in shape to be proffered by us to all nations. James Parton says of this celebrated "model draft of a treaty": "What an amiable, harmless, useless document it seems! But it was the first serious attempt ever made to conduct the intercourse of nations on Christian principles; and it was made by three men to whom ignorance has sometimes denied the name of Christians." This is a partial error. The instructions to our Ministers abroad, drawn by Jefferson, when he was a member of the Continental Congress, was the "first attempt" of this sort, and "the model treaty" and it are so much alike that plainly the latter is based on the former. I expect, if I live to the Scriptural limit of age, to see the main provisions of that treaty adopted by the civilized nations of the earth in their intercourse with one another, thereby confining the evils of war - always unnecessary and barbarous within as narrow limits as possible. Already privateering has been abolished, which was one of the things the authors of "the model treaty" sought. The whole world admits, that there ought to be no confiscation of neutral property - another thing they sought. I hope the day is not far distant, when war will bring "no molestation to fishermen, farmers," and other noncombatants, and "no useless ravaging of the enemy's coast at a point where the enemy has no ships or arms," which constituted another of their aims.

Another of their objects was that there should be, "no crowding of prisoners of war into unwholesome places." Already this example had been set by Jefferson's advice and active aid among "the sweet hills of Albemarle," where nearly a whole county and the open air had 
constituted the only prison of our British and Hessian captives. Some day a nation will not call itself respectable which does not obey the precept of the Model Treaty on this head. And why should we not hope to see the day when Article XVII shall be in effect? That Article read:-

"If the citizens or subjects of either party, in danger from tempests, pirates, or other accidents, shall take refuge with their vessels within the harbors or jurisdiction of the other, they shall be received, protected, and treated with humanity and kindness, and shall be permitted to furnish themselves at reasonable prices, with all the refreshments, provisions, and other things necessary for their subsistence, health, and accommodation, and for the repairs of their vessels."

Are not people anyhow somewhat too prone to call humanly attainable things "visionary"? Was not old George Washington practical? He said of that draft of a treaty that it "marks a new era in negotiation," and "old Frederick of Prussia," as Jefferson calls him, was a right hard-headed old fellow, and he entered into a treaty with us containing substantially these things. Let us not take for granted that people, who want to improve the world and make nations treat one another just as civilized gentlemen treat one another, are necessarily vision-seeers. May be, it might be wiser to drop one $e$, and call them seers instead?

Parton says, and I cannot make up my mind whether he says it in derision or in earnest:-

"In short, the commission to negotiate commercial treaties had but one important result, namely, the composition of the draft of the treaty and its preservation in the Diplomatic Correspondence of the United States against the time when nations shall want it." 
May God speed the coming of the time, and may God equally speed the cessation of talk about such a time as "impracticable" and "visionary!" If, as he says, the treaty "remains only as an admonition and a prophecy," it is at least an admonition Godward, because Peaceward; and a prophecy which will be fulfilled, if the world grows from mere civilization to that enlightenment, where "the common sense of most" can "hold a fretful realm in awe."

Jefferson had made an excellent foreign minister. In the transaction of his official duties and of those extra official duties, which consume so much of a foreign minister's time, he had been patient, tactful, courteous and wise. His dispatches home are among the greatest state papers which we have. He had shown himself in France, as earlier in Virginia and later at Philadelphia and Washington, an excellent judge of men. Even Judge Marshall, who hated him, says: "and in that situation" (that is, as Minister to France) "he acquitted himself much to the public satisfaction."

Later Webster, who had no great use for Jefferson, speaking of his services abroad, says: "No court in Europe had at that time in Paris a representative commanding or enjoying higher regard, for political knowledge, or for general attainments, than the minister of this then infant republic."

The contemporaneous Edinburgh Review referred to his "watchfulness on every subject," his perseverance, his skill and knowledge, as not suffering in comparison even with Franklin's diplomatic talents, and to his public letters as "excelling in excellence an equal 
twelve month's letters from any British Ambassador."

But it was as Secretary of State and President that Jefferson left a lasting impress on this Government's International Relations.

On his way from Norfolk to Monticello after he had landed in America, he received the letter from General Washington offering him the place of Secretary of State, really then, as now, the Cabinet Premiership. Jefferson reluctantly forewent his desire to remain in the diplomatic service and accepted. He arrived in New York, after a visit on the way to his old friend Benjamin Franklin, and immediately took up the three months arrears of work in the Department of State.

As almost the first thing, the reader may compare, certainly with credit to Jefferson, not only in point of patriotism, but in point of prescience, his words, as Secretary of State, asserting the right of navigation of the Mississippi River - with its subsequent tame surrender for twenty-five years by Jay, as Foreign Minister, and by Washington, as President, in the memorable Jay Treaty.

Jefferson's letters of instruction to Carmichael and Short on this subject are instructive and interesting, especially in this: that he based our claim not only on the Treaty of Paris of ' 63 and the Treaty of 1782-83, but characteristically upon the announcement of an "abstract proposition," to wit: that "the right to a thing gives a right to the means without which the thing can not be used." He calls this a "still broader and more unquestionable ground," than the treaty grounds, and adds that, "if the right of the upper inhabitants to 
descend a stream is in any case obstructed, it is but an act of force by a stronger society against a weaker, and is condemned by the judgment of mankind."

Anticipating that Spain might make the argument, that, if she granted the navigation of the Mississippi to the United States, she must likewise, under the "most favored nation" clause of her treaties, grant it to others, he denies that the most favored nation clause could be invoked, because "Spain does not grant us the navigation of the river; we have an inherent right to it."

On the 24th of April the first Federal precedent of our position to be taken in matters of extradition was settled, and our time-honored policy with regard to political offenses was initiated. An extract from Jefferson's instructions will explain itself. The reader will see from reading it that this, too, was the beginning of a permanent policy on the part of our Government:-

"Treason. This, when real, merits the highest punishment. But most codes extend their definitions of treason to acts not really against one's country. They do not distinguish between acts against the government and acts against the oppressions of the government; the latter are virtues; yet they have furnished more victims to the executioner than the former; because real treasons are rare; oppressions frequent. The unsuccessful strugglers against tyranny, have been the chief martyrs of treason laws of all countries.

"Reformation of government with our neighbors, being as much wanted now as reformation of religion is, or ever was anywhere, we should not wish, then, to give up to the executioner, the patriot who fails, and flees to us. Treasons, then - taking the simulated with the real - are sufficiently punished by exile."

Soon after, Jefferson had to meet, for the first time in our history, another troublesome question: the question of how far the dual character of our republic must be 
considered by foreign nations in the interpretation of treaties with the United States. The United States had undertaken to secure that there should be no legal obstructions to the collections of debts due to British subjects. The British had cause to complain, because there were obstructions in the State Statutes, and they were holding our frontier forts until we had complied with the treaty, in the way that they construed it.

Upon this question Jefferson and Hamilton came into clash. Jefferson was requested to put his views in writing and hand them to the President, which was done. In this paper he took the position that the British Government must have understood beforehand the dual nature of our institutions; what would be the force and extent of a Federal power; and that any interference with the States by the United States, as a Government, must be, to use his own language, "not a matter of obligation, or coercion, but of persuasion and influence merely," as the United States Government under our system had not power to control State Legislatures or State Courts, and could not be taken to have stipulated in the treaty to do what it could not do; that the Government had observed the treaty to the extent of its power by making recommendations and by using all its influence. This precedent, too, all intelligent Presidents and Secretaries of State have since followed.

Jefferson, being our first Secretary of State, his acts and utterances, have had a more permanent effect upon our history with regard to international affairs than those of any other man. In many matters he was overridden by the Cabinet, but not with regard to 
foreign affairs. In fact, in some instances, the President supported him against all the balance of the Cabinet - a very, very rare thing for Washington to do - so rare that I have no knowledge of his having done it with regard to any of his other Secretaries.

Early in November, America heard with astonishment of the dethronement and imprisonment of the King of France, and a Cabinet consultation was held upon the subject - whether we should suspend our payment of the French debt. Jefferson thus sums up what occurred:-

"I admitted that the late Constitution was dissolved by the dethronement of the King; and the management of affairs surviving to the National Assembly only, that this was not an integral legislature, and therefore not competent to give a legitimate discharge for our payment; that I thought consequently that none should be made until some legitimate body came into place; that I should consider the National Convention called, but not yet met, to be a legitimate body. Hamilton doubted whether it would be a legitimate body, and whether, if the King should be re-established, he might not disallow such payments, on good grounds."

The Cabinet meeting ended by an agreement that Jefferson was to write to Gouverneur Morris to suspend payment "till further orders." These further orders were sent, when the National Convention "came into place," to the effect that we acknowledge the obligation of the debt and were ready to pay what was due. The policy here outlined, as Jefferson's opinion, became a permanent policy in our Government. Foreign debts ever since have been regarded by us as International, not Inter-dynastic.

On September 19th, in a letter to our Minister in England, Jefferson outlined what he called the "Cath- 
olic Principle of Republicanism," as regards recognition of governments. It is this:-

"We certainly cannot deny to other nations that principle, whereon our own government is founded; that every nation has a right to govern itself internally, under what form it pleases, and to change these forms, at its own will; and, externally, to transact business with other nations through whatever organ it chooses, whether that be a King, Convention, Assembly, Committee, President, or whatever it be. The only thing essential is, the will of the nation. Taking this as your polar star, you can hardly err."

He had already said: "Principles being understood their application will be less embarrassing."

This "Catholic Principle of Republicanism" was not only a "polar star" to guide our then Minister to St. James, but all American Ministers everywhere ever since, and all Secretaries of State. We have never arrogated to ourselves the right, which the coalition of Kings then, and the Holy Alliance later, arrogated to themselves, to sit in judgment upon the form of government and the administration of domestic affairs in any country on the ground that its "principles are dangerous." The only question with us is the truly republican and democratic one: Is the actual government that which the people of the country in question have drawn over themselves?

I think it is well enough here, in view of coming events, then already casting their shadows before them, to treat the question of our treaties with France. France had given us money; lent us money; furnished fleets and armies, to gain our independence, and all the compensation she ever demanded was the fulfillment, not of all, but of some, of the promises contained 
in these treaties, which, in many material aspects, became later broken promises. I am not saying that some of the promises ought not to have been broken. Without deciding the question, I am not prepared to take the stand that a nation must abide indissolubly by the written language of treaties, even to its own probable destruction, or very great hurt. Certainly, the first duty of a nation, as well as its most natural desire, is self-preservation. At any rate Washington, a very just man, thought so. And Jefferson, as his Secretary of State, in spite of his love for the French people, and of republican institutions, went with him, in the course of a strict neutrality, which necessarily violated some of the provisions of the French Treaty.

We ought to have paid the French debt, because we owed the money, and we owed much more than the accounts showed; but we could afford to do what Jefferson recommended with regard to the guarantee hold it in abeyance until expressly called upon to make it good.

Thomas E. Watson says that this neutral position "kept us from deriving any benefits from the victories of Napoleon." But it must be remembered that the victories of Napoleon could have done us no good. His victories were on land, and the victories to save us, must have been on sea, where Napoleon could no more have helped us, than he proved able to help Denmark, or Holland, or Spain.

On this point read Jefferson's letter to President Washington, giving his opinion concerning the French treaties, and concerning how the French Minister should be received. It is perhaps the ablest of his 
papers treating international affairs. It is dated April 28th, 1793. It is one of the most forceful and lucid statements of the principle, which binds nations to their plighted word, that has ever been penned, and Washington yielded to the reasoning, notwithstanding the special and specious pleading contained in Hamilton's letter supporting the contrary view. He decided that the treaties with France remained in full force, and that the Minister from the French Republic should be received in the usual way and without the qualifications which Hamilton suggested. Ever since it has been our policy to treat Ministers also as National and not as Dynastic agents.

The Federalists immediately began to oppose our observing the French treaties upon two grounds. The first ground, or pretext, was puerile in its character, to wit, that the treaty was "not made with France, but with Louis XVI," or "Louis Capet," as they called him in their arguments, who, being dethroned, left us, as they contended, under no international obligations to France, "except those which flowed from the general principles of international law." The excuses which Aesop's wolf gave for eating up Aesop's lamb are the only precedents which I know, which could justify this bare-faced pretext to breach a solemn covenant. The second reason was that our guarantee came into force only in case of "a defensive war." The reply to that is that the language of the treaty of alliance, in Articles XI and XII, does not bear it out, but expressly declares the opposite.

Clearly, if language be given to express, and not to conceal ideas, Article XVII of the Treaty of Amity 
and Commerce gave to French ships of war and privateers the right to enter and harbor themselves in any of our ports, carrying with them their prizes. We surrendered even the right of making examination, as to the lawfulness of the prize. That is not all; there was a clear and distinct promise, on our part, that we would not give shelter, or refuge, to the ships of war and privateers of a nation at war with France, and that even if stress of weather forced them to take temporary refuge with us, they must go out, as soon as possible. On this head two things were afterward contended: first, that France had no right to bring prizes within our ports, and secondly, that permitting her, out of our grace, to exercise such a privilege, we not only had the right, but it was our duty as a neutral nation, to extend the same privileges to England. Both of these contentions were in the very teeth of the express provisions of Article XXII of the Treaty of Amity and Commerce.

Whatever reasoning, good or specious, may be used to justify or excuse our Government for the violation of these special provisions of the two treaties, it is well, in the interest of candor and truth, that everybody should cease to deny that they were violated. The fact ought to be admitted simply because it is a fact, and not be glossed over. The material results of the violation were happy for us, and, it may be, for the entire world; happy for us, because our States were perhaps then too loosely united to have withstood the convulsions of a foreign war, which would have been accompanied undoubtedly by internal dissensions. New England would have taken, had we stood by our 
alliance with France, against Great Britain, under Washington's administration, the same position which she afterwards took under Madison's, and publicly advertised, while resisting the embargo, that she would take under Jefferson's, if he dared to go to war with England. Her position became less dangerous to the Union just in proportion as meeting it was postponed, while the West grew. There was no man then, who entertained a doubt of the right of a State to withdraw from the Union. At any rate, Washington would have felt, as Jefferson afterwards confessed that he felt, "the foundations of the government shaken under his feet by the action of the New England Townships." Moreover, even if we had gone through the war successfully and unitedly, we were then so hampered in our finances, that we would have emerged temporarily bankrupt, or if not that, at least after the issue and depreciation of another immense mass of paper money. The results were happy for the civilized world, too, because, if, at that early date, before England always, like ourselves, "an unready nation" - had organized her fighting strength, we had kept a part of her navy busy on this side of the Atlantic, it is possible, though not certain, that the great Napoleon might have realized his dream of world-empire. Notwithstanding all this, however, it will be seen that those, who denied the right of the Executive to issue a declaration of neutrality, forestalling the action of Congress and violating the written provisions of the French treaties, were not nearly so clearly wrong, as the respect and the reverence of the American people for the character and memory of George Washington have led them easily 
to believe. The argument that France had done all she did for us, not really out of love for us, but out of hatred of Great Britain, although an argument founded on fact, is not a valid one. We accepted her assistance - knowing her motive - accepted her guarantees in the treaty, as the reciprocals of ours and as safeguards of our national existence and independence, when we were in our very infancy, and thought that we needed safeguards, whether we did or not. However, we were relieved from the awkwardness of our situation very much by the fact that Genet, who succeeded Ternant, when officially presented, said to Jefferson, Secretary of State: "we know, that, under present circumstances, we have a right to call upon you for the guarantee of our islands. But we do not desire it. We will wish you to do nothing but what is for your own good, and we will do all in our power to promote it. Cherish your own peace and prosperity."

It was at this time, and not later - when Genet had turned fool - that Jefferson expressed to Madison his oft-quoted appreciation in these words: "It is impossible for anything to be more affectionate, more magnanimous, than the purport of his [Genet's] mission," and added in another part of the letter: "In short he offers everything and asks nothing."

Jefferson was all the more gratified at Genet's highflown, though short-lived, magnanimity, because he had evidently expected him to call upon us to comply at once with our treaty obligations. This is my inference, but I hazard it, because at the very beginning of Genet's queer doings in America, while he was being welcomed in Philadelphia with enthusiasm, after 
his equally enthusiastic welcome at Charleston, Jefferson wrote to Monroe: "I wish that we may be able to repress the people within the limits of a fair neutrality." This shows that he was that early determined on neutrality, and afraid that the hand of the administration might be forced by the popular enthusiasm for France, with which he then sympathized.

Mr. Foster, in his "Century of American Diplomacy," writes with a distinct Federalistic and antiJeffersonian bias - "leads up" - as Mark Twain said he did to one of his poetical quotations - to injurious things he wants to say about Jefferson. Many of them are purely personal, like his laborious lugging in of Tom Moore's false couplet, which had naught to do with a history of "Diplomacy."

It will be noted that Jefferson, to whom the real credit is due for setting forth, in the ablest State paper ever written - in a way so masterly that it has never been improved on - the whole doctrine of neutrality and its special advantages to us, is not given the credit by Mr. Foster. The truth is that, as far as our foreign relations under Washington are concerned, they were, for the most part, an expression of Jefferson's policies.

In proof of what I say here, read the unequalled statement by Mr. Jefferson as President of the duties of a neutral: -

"Let it be our endeavor, as it is our interest and desire, to cultivate the friendship of the belligerent nations by every act of justice and of innocent kindness; to receive their armed vessels with hospitality, from the distresses of the sea, but to administer the means of annoyance to none; to establish in our harbors such a police as may maintain law and order; to restrain our citizens from embarking 
individually in a war in which their country takes no part; to punish severely those persons, citizens or aliens, who shall usurp the cover of our flag for vessels not entitled to it, infecting thereby with suspicion those of real Americans, and committing us into controversies for the redress of wrongs not our own; to exact from every nation the observance, towards our vessels and citizens, of those principles and practices which all civilized nations acknowledge; to merit the character of a just nation, and maintain that of an independent one, preferring every consequence to insult and habitual wrong."

And these further lines, where he tells how neutral conduct especially redounds to the interest of this country and its people:-

"Separated by a wide ocean from the nations of Europe, and from the political interests which entangle them together, with productions and wants which render our commerce and friendship useful to them, and theirs to us, it cannot be the interest of any to assail us, nor ours to disturb them. We should be most unwise, indeed, were we to cast away the singular blessings of the position in which nature has placed us, the opportunity she has endowed us with, of pursuing, at a distance from foreign contentions, the paths of industry, peace and happiness; of cultivating general friendship; and of bringing collisions of interest to the umpirage of reason rather than of force. How desirable, then, must it be, in a government like ours, to see its citizens adopt, individually, the views, the interests, and the conduct, which their country should pursue, divesting themselves of those passions and partialities which tend to lessen useful friendships, and to embarras and embroil us in the calamitous scenes of Europe. Confident, fellow citizens, that you will duly estimate the importance of neutral dispositions towards the observance of neutral conduct, that you will be sensible how much it is our duty to look on the bloody arena spread before us, with commiseration, indeed, but with no other wish than to see it closed, I am persuaded that you will certainly cherish those dispositions in all discussions among yourselves, and in all communications with your constituents.". 
And yet, "history-writers," as the children call them, of the Federalistic type, represent him as having been "forced to a system of neutrality by the President." The truth is that, although the bulk of Jefferson's party were carried off their feet temporarily by sympathy with France and though her people had his heart-felt good wishes, he never permitted his gaze to be deflected from the interests of his own country.

When Genet carried things entirely too far and threatened to "appeal from the President to the people," and all that, the question arose in the Cabinet, as to what should be done, and here again Jefferson kept his head. Knox wanted to send Genet out of the country "by a public order without ceremony." Hamilton, who was an astute party manager, wanted to publish the correspondence on both sides, accompanied by a statement on the part of the Government of its proceedings, in order to arouse popular feeling against France - rightly counting that the people would not, in their anger at Genet's treatment of Washington, distinguish between France and her Minister. Jefferson coolly advised that the usual course be pursued, which was that we send an account of the affair to the French Government, and demand the recall of Genet. George Washington, cool-headed himself on this occasion, and on most occasions - though not on all sided with Jefferson. The complaint and the demand were made. They were acceded to. Genet was recalled, and that tempest in a tea-pot became comparatively a calm.

In Jefferson's communication to the American Commissioners at Madrid, on June 30th, he uses this 
language, which should, if it does not, constitute permanently a part of the very soul of our relations with foreign nations:

"We love and we value peace; we know its blessings from experience; we abhor the follies of war, and are not untried in its distresses and calamities. Unmeddling with the affairs of other nations, we have hoped that our distance and our disposition would have left us free in the example and indulgence of peace with all the world. . . . We confide in our strength without boasting of it; we respect that of others without fearing it."

That is crisp and lofty. Its style is Demosthenic.

The two wise heads in the Cabinet were determined, if they could help it, not to have war with anybody, although our relations with Great Britain and France both, as well as with Spain, were becoming daily more and more embarrassing. In addition, the people of the United States, as some foreigner, then visiting us, reported, "were all either Englishmen, or Frenchmen, and none Americans." Washington was standing firm and prudent. His critics said, as others said a dozen years later of Jefferson, that his course was "overcautious" and "pusillanimous."

Jefferson's request for the recall of Genet was dated August 16th. In his dispatch he uses this language: "If our citizens here have not already been shedding each other's blood, it is not owing to the moderation of Mr. Genet." This from Jefferson had greater effect in France than if written by any man in the world, not a Frenchman. Genet was not only recalled, but in such spirit, that he was afraid to return to France, and settled in America.

While Secretary of State, in a letter to Chancellor 
Livingston, who was on the eve of departing for France, to be our Minister there, he wrote, on September 9th, a letter upon the question as to whether neutral ships should make free goods, in which he touched upon the question of blockade. The letter has, upon the whole, constituted the American doctrine upon these subjects, though some of the reasons given are in themselves curious, starting out, as Jefferson always liked to start, from grounds of natural and abstract right. This letter is well worth close study. To some extent, his doctrine concerning contraband is in advance even of the present European practice, but has constituted since, in the main, the American contention.

For reasons unconnected with Diplomatic affairs Jefferson had determined to retire from the Cabinet. Washington had thus far kept him in office by appealing to him on the ground that it was not the part of a "general officer" to resign upon the anticipated outbreak of war. Madison and his friends had added their voices for a far different reason. They wanted his party leadership on the spot. But on July 31, 1793, in spite of the solicitations of both President and friendsthe ship of state being seemingly in safe harbor, so far as international billows could threaten her - he sent in his letter of resignation to take effect the 1st of September.

On August 6th, after the receipt of this letter, the President called upon him. I think there was something pathetic in George Washington's being chained to office, as a post of duty, and trying to chain Jefferson to it, at a time when both were tired nigh unto death 
of it all, and were yearning for the large and restful spaces of the plantation. He seems, even after all the warning he had had, to have taken Jefferson's letter in a hurt sort of way, because, upon this visit, he expressed his repentance at not having resigned himself, and said that that repentance was "increased by seeing that he was to be deserted by those on whose aid he had counted."

Finally, the President said, that if Jefferson could "only stay to the end of another quarter," which would be till the last of December, instead of the 1st of September, the date fixed in Jefferson's note, "it would get us through the difficulties of this year," because he was "satisfied that the affairs of Europe would be settled at the end of the pending campaign - either France being overwhelmed, or the coalition retiring from the contest." Jefferson's party friends had begged him to do this too. He had positively refused them, but a few days afterwards he conceded that postponement to Washington, which he had refused to them. The President, in a letter, dated the 12th of August, puts in another plea to extend further the period for the resignation "until the close of the next session of Congress," for which he proffers many weighty reasons, relating to foreign powers, Indian disturbances, and internal policies. This persistency is touching. Washington concludes his letter: "If this cannot be, my next wish is that your absence from the seat of Government in autumn may be as short as you can conveniently make it." All this, notwithstanding the fact that many months had elapsed since Washington had lost his temper and sworn about Freneau, since Jeffer- 
son had entered in his diary that it was plain that he wanted him to dismiss Freneau, and then had added these measured words: "but I will not do it," and did not; thereby giving Washington his choice of dismissing both Freneau and him, or neither. Washington seems to have understood. Federalist "history writers" and their political descendants are so dense!

On December 21st, the President, who was untiring in his persistency, made another effort by letter to get Jefferson to postpone his resignation yet further, but this time without effect, and on December 31st, the last day of the quarter, as previously determined, Jefferson sent it in. Read that letter, following it with the perusal of Washington's reply. I think the reader must agree with me that the insinuations and charges of historians with Federalistic leanings - some of them writing not unrecently - that Washington "had grown to distrust Jefferson," and was "glad to get him out of the Cabinet," that Jefferson "was compelled to resign," are sufficiently refuted by the history of their relations up to this moment; in fact, proven to be stupendous ignorance, or else stupendous lies. If not, they are conclusively refuted by these two letters, unless the reader be prepared to consider both men thorough-paced hypocrites. Jefferson's was dated December 31, 1793. Washington's reply was dated the next day, January 1, 1794, at the same place.

The message to the next Congress concerning our international relations, which was sent in on the fourth Monday in December, was prepared and left by Mr. Jefferson and signed by President Washington. A draft of it in his handwriting was among his literary 
remains, as was also the Presidential confidential message containing our diplomatic correspondence with Spain, which was sent in by the President on the 16th of December. On this same day, in response to a resolution of the House, passed February 23, 1791, Jefferson's celebrated "Report on the Privileges and Restrictions of the Commerce of the United States in Foreign Countries" was sent in.

When Jefferson's diplomatic state papers were sent to Congress their tone, their total want of any foreign bias, their felicity, facility and lucidness of expression, their "sweet reasonableness," their dignity and firmness, their lack of either bullying or cringing, were the causes of spontaneous and irrestrainable public and private applause.

Daniel Webster writes of Jefferson as Secretary of State as follows:-

"Immediately upon his return to his native country ... his talents and experience recommended him to President Washington for the first office in his gift. He was placed at the head of the Department of State. In this situation, also, he manifested conspicuous ability. His correspondence with the ministers of other powers residing here, and his instructions to our diplomatic agents abroad, are among our ablest State papers. A thorough knowledge of the laws and usages of nations, perfect acquaintance with the immediate subjects before him, great felicity, and still greater facility in writing, show themselves in whatever effort his official situation called on him to make."

Senator Vest, of Missouri, in an address at Columbia, Missouri, on June 4, 1885, expressed himself yet more glowingly.

Even Judge Marshall writes grudgingly: "This gentleman withdrew from public station in a moment, 
when he stood particularly high in the estimation of his countrymen," and then goes on to belittle his grudging concession by explanations, which do not reduce it, but do reduce Marshall.

If Jefferson was fortunate in the time of his retirement, as Marshall intimated, credit is due solely to Jefferson, because, except for his acts and efforts, we could not have emerged with peace and honor from our labyrinth of international difficulties, and the only fortunate thing about it, as far as Jefferson's fortunes were concerned, to wit, the universal applause which followed him, could not have existed. It is not too much to say that Jefferson had for these years virtually controlled the foreign policy of the United States. In no single case, that I can find, were his suggestions and propositions concerning foreign affairs in any essential overruled. He went reluctantly, it is true, into the violation of the French treaties, believing that State necessity alone justified it, but he saw as fully as Washington did the necessity of "standing out from under" in every possibly honorable way. He never did, however, dishonor himself by denying the obligations of the treaties. He did not add hypocrisy to bad faith. He simply accepted the bad faith as the necessity of the situation, the less of two evils. A man has no right to sacrifice his honor to save his own life. But a public servant may perhaps sacrifice the word of a nation to save a nation's life, or to save its people great hurt - militarily and institutionally.

Washington made one more effort early in September, 1794, to get Jefferson to resume his place in the Cabinet. This was after the latter had been for 
some time in retirement at Monticello. He did this through Randolph, temporarily Secretary of State. Jefferson's reply to Randolph is worth reading.

After retirement Jefferson, in a letter to Edward Rutledge, on November 30th, lays down, in connection with the Jay Treaty, a diplomatic principle that may be fairly considered as having gone permanently into the working of our institutions; a principle that where a treaty is made, and contains in it some promise or undertaking (like the payment of money, for example), jurisdiction over which is vested in Congress, Congress being a free and independent and coördinate branch, it can, within its sound discretion, comply with, or refuse to comply with, the provisions of the treaty by making, or refusing to make, the appropriation. This depends, too, upon the principle that foreign nations are affected with the knowledge of the nature of our Government. Jefferson expresses it in these words: "Both negotiators must have understood that, as there were articles in it, which could not be carried into execution without the aid of the Legislatures on both sides, therefore, it must be referred to them," and that, "these Legislatures being free agents would not give it their support, if they disapproved of it." Subsequently, in the treaty acquiring Louisiana, he as President obeyed strictly the precept here laid down for others. He submitted the Louisiana Treaty to both Houses, "because," he said, "both have important functions to exercise respecting it."

So much for the Jeffersonian view of the rights of the House of Representatives concerning treaties.

Now for the Jeffersonian view of the President's rights respecting treaties:- 
On the 19th of February, 1807, President Jefferson announced to Congress that a treaty of peace had been agreed on with England. Soon after that the treaty which had been negotiated by Monroe came over. He found to his surprise that it did not touch upon the question of impressment of our sailors; that Great Britain did not disclaim this alleged right. He, therefore, took the responsibility of not sending the treaty to the Senate. He was much, even bitterly criticised for this at the time. He acted within his right; because, if he were not going to sign the treaty and had made up his mind that he would not, it was "love's labor lost" for the Senate to discuss it. The precedent set by him here has been acknowledged ever since, and has become engrafted upon our working institutions. It will be remembered that the Jay Treaty, under General Washington's administration, was also silent on this head of impressment, and yet Washington signed it. Jefferson had criticised him for it. His own conduct in and out of office was therefore consistent.

Jefferson took the position that signing a treaty that was silent upon the subject was an acquiescence in, and therefore a quasi-recognition of, the British claim to the right of impressment, and that it was better, to use his characteristic language, "to let the negotiation take a friendly nap, and endeavor in the meantime to practice on such of its principles, as are mutually acceptable."

Jefferson's reason for rejecting (by not submitting to the Senate for their action), this treaty effected by Monroe with Great Britain on December 31, 1806, is 
expressed more happily by Henry Adams than I could express it myself. I therefore quote from him:-

"That a people like an individual, should for a time choose to accept a wrong, like impressment or robbery, without forcible resistance, implied no necessary discredit. Every nation at one time or another had submitted to treatment it disliked and to theories of international law which it rejected. The United States might go on indefinitely protesting against belligerent aggressions, while submitting to them, and no permanent evil need result. Yet a treaty was a compromise which made precedent; it recorded rules of law which could not be again discarded; and, above all, it abandoned protest against wrong. This was doubtless the reason why Jefferson wished for no treaties in the actual state of the world; he was not ready to enforce his rights, and he was not willing to compromise them."

In April, 1794, in this same letter to Madison, to which I have once referred, appears the first inkling of the central idea of the Monroe Doctrine. He expresses the view that "we ought at the proper time to declare to both France and to England, that the French West India Islands were to rest with France, and that we should make a common cause with her for that object." This seems to preclude the idea of France's voluntarily transferring, as well as of England's forcibly acquiring them, and this is virtually our present attitude towards the West India Islands: "those who have, can keep; those who have not may not acquire," whether by war or purchase.

On October 29, 1808, Jefferson wrote a letter to the Governor of Louisiana, in which is to be found a plain expression of the principle of the Monroe Doctrine, and, as far as I know, the last sentence in the quotation which I am about to make, is the first absolutely distinct expression of it ever made by anybody:- 


\section{PERMANENT INFLUENCE OF JEFFERSON}

"The patriots of Spain have no warmer friends than the administration of the United States, but it is our duty to say nothing and to do nothing for or against either. If they succeed, we shall be well satisfied to see Cuba and Mexico remain in their present dependence; but very unwilling to see them in that of either France or England, politically or commercially. We consider their interests and ours as the same, and that the object of both must be to exclude all European influence from this hemisphere."

In a letter to Short, dated August 4, 1820, is another anticipation of the Monroe Doctrine:-

"From many conversations with him" (Mr. Correa, appointed Minister to Brazil by the Government of Portugal), "I hope he sees, and will promote in his new situation, the advantages of a cordial fraternization among all the American nations, and the importance of their coalescing in an American system or policy, totally independent of and unconnected with that of Europe. The day is not distant, when we may formally require a meridian of partition through the ocean which separates the two hemispheres, on the hither side of which no European gun shall ever be heard, nor an American on the other; and when, during the rage of the eternal wars of Europe, the lion and the lamb, within our regions, shall lie down together in peace."

In another letter to Short, dated August 20, 1820, he speaks of the "essential policy of interdicting in the seas and territories of both Americas the ferocious and sanguinary contests of Europe." This is very much like the language he wrote to Monroe in 1823, to wit: "Our first and fundamental maxims should be never to entangle ourselves in the broils of Europe; our second, never to suffer Europe to interfere in Cis-Atlantic affairs."

In the Fortnightly Review, No. 5, Vol. 70, pages 357 to 368 , may be found an interesting and authoritative article by Theodore A. Cook on "The Original Intention 
of the Monroe Doctrine," as evinced by the correspondence of Monroe with Jefferson and Madison. Mr. Cook shows clearly that it was Jefferson's position, clear and decisive, rather than the more cautious one of Madison, or that of John Quincy Adams, that was taken by the President.

By the time then that, under Monroe's administration, it had become necessary for us to decide on our attitude, if the Holy Alliance should undertake to interfere in Spain's behalf against her South American colonies, which had declared and partially effected their independence, Jefferson was prepared in set opinion for the event. Monroe, who generally met Jefferson every Spring and consulted with him verbally, but had not been able to do so this year, wrote him two letters upon this subject. Jefferson's replies are memorable, since his suggestions make the very soul of the subsequent declaration, which came to be known as "the Monroe Doctrine," and for which Monroe deserved the credit because his was the responsibility. Jefferson goes somewhat further than the President and his Cabinet thought prudent to follow.

Meantime Canning made his proposition, which was, in substance, that America should declare that she would regard the intervention of the powers constituting the Holy Alliance, as an unfriendly act, and intimated that Great Britain would stand with us behind the announcement. The President thereupon had written to Mr. Jefferson his second letter and, on October 24th, Jefferson wrote him a reply, in which the Monroe Doctrine stands full born:- 


\section{"Dear Sir:}

"The question presented by the letters you have sent me is the most momentous which has ever been offered to my contemplation since that of Independence. That made us a nation, this sets our compass and points the course which we are to steer through the ocean of time opening upon us. And never could we embark on it under circumstances more auspicious. Our first and fundamental maxim should be, never to entangle ourselves in the broils of Europe. Our second - never to suffer Europe to intermeddle with cis-Atlantic affairs. America, North and South, has a set of interests distinct from those of Europe, and peculiarly her own. She should therefore have a system of her own, separate and apart from that of Europe. While the last is laboring to become the domicile of despotism, our endeavor should surely be, to make our hemisphere that of freedom. One nation, most of all, could disturb us in this pursuit; she now offers to lead, aid and accompany us in it. . . . Not that I would purchase even her amity at the price of taking part in her wars. But the war in which the present proposition might engage us, should that be its consequence, is not her war, but ours. Its object is to introduce and establish the American system, of keeping out of our land all foreign powers, of never permitting those of Europe to intermeddle with the affairs of our nations. It is to maintain our own principle, not to depart from it. . . . But I am clearly of Mr. Canning's opinion, that it will prevent instead of provoking war. With Great Britain withdrawn from their scale and shifted into that of our two continents, all Europe combined would not undertake such a war. For how would they propose to get at either enemy without superior fleets? . . I I could honestly, therefore, join in the declaration proposed, that we aim not at the acquisition of any of these possessions; that we will not stand in the way of any amicable arrangement between them and the mother country; but that we will oppose, with all our means, the forcible interposition of any other power, as auxiliary, stipendiary, or under any other form or pretext, and most especially their transfer to any other power by conquest, cession, or acquisition in any other way.

Note especially the last paragraph. It is broader, more far-reaching and clearer than the doctrine as 
announced officially by Monroe, though Jefferson's suggestion contains every word of the Monroe declaration and even all that we have since changed it to mean.

Jefferson set the precedent while Secretary of State for the forms now obtaining in the Department. They are of the utmost simplicity and thoroughly democratic. A Secretary of State is not properly addressed even as an, "Honorable," as are Senators and Representatives and other Department officials. $\mathrm{He}$ is "Mr. John Smith, Secretary of State," or "John Smith, Esquire, Secretary of State." We have in our State Department no bureau of ceremonials and etiquette and precedents. Such bureaus exist in other countries, even in the Republic of France, as well as in the Monarchy of Great Britain. In France there is a man whose special business it is to introduce Ambassadors, and act as master of ceremonies at the Elysée. A good many snobs regret our simplicity; some of them engaged in the service of the State Department at Washington, and some elsewhere writing or talking. It has also been regretted that we have not imitated the British in some other respects. The British Foreign Office, for example, requires its clerks to know German and French, and the degree of knowledge of French required is very great. This cuts the British Foreign Office off from very much talent. Some of the best clerks in our State Department, if such a rule existed there, would have to go. Of course, a knowledge of foreign languages is needed in the translating department, but there is no sense in requiring that all clerks should be acquainted with these two, or any foreign languages. 
There exists a very general impression that other countries have the advantage of us in diplomatic affairs, because they have greater secrecy. It is a mistake. There is no country anywhere, where the public knows less of the negotiations going on in the Department of Foreign Affairs, until they are ready to be announced or communicated to the Senate. First as Secretary and later as President, Jefferson insisted on and practiced this secrecy in preliminary negotiations.

Our Minister of Foreign Affairs - which is what our Secretary of State's title really ought to be - has one embarrassment that his colleagues in other countries do not have. The Senate has always asserted the right to amend a treaty, as well as to ratify or reject it. At first this caused a good deal of friction. Canning, when Prime Minister, read us a regular lecture upon the subject, as if we had been school children and he schoolmaster. The custom grows out of that clause of the Constitution which says that the President, "with the advice and consent of the Senate," shall conclude treaties. The Senate has construed the authority to "advise" to be an authority to amend. It "advises the ratification" "with the following amendments" etc. Jefferson stoutly maintained the right of the Senate.

Mr. Jefferson followed the British example of using English, as the official language of diplomacy in Washington, and by our Ministers and Ambassadors abroad. Neither our Government, nor that of Great Britain, has ever conceded the point, that "French is the language of diplomacy."

He early adopted the rule, which existed in some 
other countries, of "first come, first served," when Ambassadors and Ministers came to confer with the Secretary of State. In Jefferson's day, however, we neither sent nor received Ambassadors. "Minister Plenipotentiary" or "Envoy Extraordinary" were the highest titles of our Diplomatic Corps. Here, as always elsewhere, he displayed genuine democratic simplicity - Jeffersonian simplicity - no mystery no airs - no set forms. Common sense and kindly feeling and courteous treatment, constituted an allsufficient etiquette for foreign and official, as for domestic and private affairs.

The letters exchanged between Jefferson, as Secretary of State, and Hammond, as British Minister, are well worth attention, especially Jefferson's dispatch to Hammond dated May 29, 1792. In it are many things of permanent value, besides, it is one of the most carefully and convincingly written even of Jefferson's great papers touching international law and international relations.

During these negotiations at one time Hammond suggested the idea of both parties giving up all fortified posts along the Canadian border, having no "posts," except for trading. Jefferson replied that this "accorded well with two favorites of mine, of leaving commerce free, and of never keeping an unnecessary soldier." Since then, this policy of disarmament on the border and on the Great Lakes became a settled and mutual policy of both nations, and I doubt not that it accounts for the fact that we are soon to celebrate the centennial anniversary of uninterrupted peace with Great Britain. 
I have elsewhere referred to the repeal of the Federalist naturalization law and the reënactment of the more liberal one. The effect of this treatment of foreigners and this encouragement of unassisted immigration, upon our growth and upon the amicableness of our relations with other nations and upon the material welfare of mankind, here and abroad, cannot be overestimated. Mr. Jefferson elsewhere expressed his opposition to assisted immigration. The restrictions which we have since put upon immigration would undoubtedly have been favored by him, as they only relate to the health and character and intelligence of the immigrants, or else to the preservation of the Caucasian race from the infiltration of Oriental bloods to the maintenance of a homogeneous population.

We ought to have in our midst no alien races, unassimilable in lawful wedlock. Our prohibition of Mongolian immigration ought to be extended to Africans. I attempted to secure this in the last Congress, but failed. Political reasons - or Republican party reasons - the fear of the defection of the negro vote in the doubtful Northern States - account for the failure.

Of course, the grandest diplomatic achievement of Mr. Jefferson, and that affecting most permanently all our institutions and our destiny, was the acquisition of Louisiana, and the foundations laid by him, and later built upon successfully to acquire Florida. For the latter I shall have no space at all. The former I hope to treat in another lecture. 


\section{CHAPTER V}

\section{JEFFERSON THE DEMOCRATIZER OF FEDERAL INSTITUTIONS}

\section{STEMMING THE COUNTER-REVOLUTION}

JefFerson, once back in America, as soon as he could get his bearings, took up in earnest the greatest and most successful work of his life - that of turning back the tide of counter-revolution. His stay in France had had but one political effect - to teach him by contrast the value of democratic forms and a democratic spirit. His every act and word after his return was a call: "Back to the principles of the American Revolution." Of all the services he rendered his countrymen, this is that for which they owe him most.

But he began his work before his return, as his letters show. Already while in France he feared the reaction which had set in at home, as a result of Shay's Rebellion in Massachusetts, emphasized later by the natural effect of the excesses in France.

It is notable that Shay's Rebellion, as it was called, which was put down by the people themselves, did not result in the death by the act of the civil government of a single man engaged in it - but it did discourage in fact, carried dismay - to the hearts of many men, who had theretofore been stalwart supporters of popular government.

Jefferson's insistence upon simplifying and democ- 
ratizing the federal government at home, in the very teeth of the excesses soon occurring in Paris and of the dangerous reaction in England and America - in Austria - everywhere - showed him to be not a visionary, but a practical man. It was the other people, who were visionaries, who did not know how to adapt the blanket to the weather, who wanted to limit our liberty, because the French had shown themselves not yet fit for it.

Parton rather humorously describes, in an article entitled, "Meeting of Jefferson and Hamilton," in the Atlantic Monthly of December, 1872, the situation in which Jefferson found himself, when he reached New York: -

"The faithful believer was now at Mecca. But he did not find the magnates of the temple so enthusiastic for the Prophet and the Koran, as more distant worshippers. He was in the situation of a person who had left his native village full of ardent Methodists, himself the most ardent of them all, and returning after five years' absence, during which he had become even more glowing, finds half the people turned Ritualists."

Parton says, that it was then in New York" the mode to extol strong and imposing governments, to regret that people were so attached to the town meeting methods of conducting public business, and to anticipate the day when America would be ripe for a government 'not essentially different from that which they had recently discarded."

Concerning the celebrated passage in Jefferson's Ana, in which he describes the character of the "dinner table conversations," where "politics were the chief topic, and a preference of kingly over republican 
government was evidently the favorite sentiment." Parton says: "No man can glance over the memorials of the time without meeting on every side confirmation of this passage."

The proof of this assertion I am about to unfold. Powell calls all this "A Suppressed Chapter of American History," and says there was "a long contest between the principles of monarchy and democracy." It is true, and our difficulty in realizing it now is found only in the fact that we have passed so far away from it. To Jefferson chiefly we owe the fact of having passed so far away from it.

It was in the spring of 1790 , soon after Jefferson arrived, that there appeared in the Gazette a series of articles, entitled, "The Discourses of Davila." The newsboys of the day poked it and more like it under Jefferson's nose, and John Adams, the Vice-President of the United States, had written it. One of the sentences in the "Discourses of Davila" was this:-

"Nations, perceiving that the still small voice of merit was drowned in the insolent roar of the dupes of impudence and knavery in national elections, without a possibility of remedy, have sought for something more permanent than the popular voice to designate honor."

Another sentence is additionally to be noted:-

"All projects of government, formed upon a supposition of continual vigilance, sagacity, virtue, and firmness of the people, when possessed of the exercise of supreme power, are cheats and delusions."

Such was the strength of this great reaction, that the old time radical - Adams, who had written these sentences, had become "not averse to a life tenure for 


\section{PERMANENT INFLUENCE OF JEFFERSON}

the President," or even an hereditary tenure, holding that the terms of office might be extended, "until they reached the life limit," and that if this was not found sufficient, they should be made hereditary. (Merriam's "Political Theories," page 134.)

To quote Adams further:-

"The proposition that the people are the best keepers of their own liberties, is not true; they are the worst conceivable; they are no keepers at all; they can neither judge, act, think, nor will, as a political body."

This is the man, who, in Revolutionary times, had said: "Where annual elections end, tyranny begins."

The point I am making is that words like these were not only being spoken at "dinner tables," as Jefferson said they were, but were being deliberately written in books, and not by irresponsible people, but by great statesmen, some of whom had been, as Jefferson later said, "Solomons in council and Samsons in the field," during the Revolution, but who had since "had their heads shorn."

I believe I love the man John Adams too much to quote further from him, but you can find more like it in his book, "The Defense of American Constitutions," and in his articles, "Discourses on Davila."

I have selected Mr. Adams as the chief illustration of how far the "Solomons in council," as well as the "Samsons in fight" - like Hamilton and Knox had retreated from their old positions, because in my opinion, he was the most disinterested, the most patriotic, the sincerest, and the least designing of all the great reactionaries. Much more extreme utterances are to be found in the letters and public addresses 
of other reactionary leaders, and in the contemporary newspapers.

For the first eight years after, as well as for some time before the foundation of the new government, these reactionary views were popular even among the people, and for ten or eleven years, were predominant with most of the educated, and nearly all the wealthy classes especially merchants, bankers, importers, fundholders, and most of the clergy, in states where the church was not yet disestablished and separated from the state.

It is paltry to say that Mr. Jefferson was "over credulous," "frightened by shadows," or "suspicious," when American public sentiment had reached the point, where a man publishing Adams' views could be elected Vice-President twice and even President once, and where men professing, without concealment, Hamilton's and Knox's views, were given cabinet positions, and where later, Alien and Sedition laws could be passed by both Houses and signed by the President, and where the hold of "the system" upon the country grew so strong that it could be shaken by nothing less than the veiled threats of the Virginia and Kentucky Resolutions. This reaction against the principles of the Revolution was especially notable in New York, the first temporary seat of government.

Lorenzo Sabine, in his "American Loyalists," asserts that "beyond all doubt" the royalist party had contained a majority of the people of the entire State of New York. Many of those, who had been loyalists during the Revolution, were, at the time of Jefferson's return, amongst the ultra-fashionable society of New York city. The women of this same fashionable society 
had, during our war, welcomed and fraternized with the British officers. Moreover, as Randall says, "Every well informed man understands, that the American Revolution began as a war against the aggressions, and not against the form, of the British Government." Thus many honest Revolutionary Whigs remained at heart "monocrats" - a word invented by Jefferson to describe a class.

To some extent everywhere the reaction had set in and was flowing along with a full current. Even at the meeting at Annapolis, although it was conceded that the sentiment of "the populace" in America was so strongly in favor of republican institutions, that a monarchical model could hardly be expected to be set up successfully, there was no lack of talk in favor of it.

Indeed, even before the Revolution was well over, American officers had entertained the idea of making Washington king.

John Jay, in a letter of January 7, 1787, directed to General Washington himself, propounds the inquiry: "Shall we have a king?" And answers it with a qualified negative: "Not in my opinion, while other expedients remain untried."

General Washington wrote to Mr. Madison on March 31st, recognizing the situation, in these significant words: "I am fully of the opinion that those, who lean to a monarchical government, have either not consulted the public mind, or that they live in a region" (meaning New England) "which (the leveling principles in which they were bred being entirely eradicated) is much more productive of monarchical ideas, than is the case in the Southern States." $\mathrm{He}$ 
adds: "I am also clear that, even admitting the utility, nay, necessity of the form, the period is not arrived for adopting the change, without shaking the peace of this country to its foundation." Even this is, you will note, a barely qualified negative. Thus it was not unpatriotic, even in Washington's opinion, to hold monarchy in ultimate contemplation - en arrière-pensée.

Madison's report, in the third person, of Hamilton's speech to the Constitutional Convention, exhibits an advocacy of as near an approach as possible to monarchy on the English model. Read it. This much of it, I excerpt: "He hoped gentlemen of different opinions would bear with him in this," and then this language, significant of my contention, follows: "and he begged them to recollect the change of opinion on this subject which had taken place, and was still going' on." Madison continues the report of Hamilton's speech:-

"The members most tenacious of republicanism, he observed, were as loud as any in declaiming against the vices of democracy. This progress of the public mind led him to anticipate the time when others, as well as himself, would join in the praise bestowed by Mr. Necker on the British Constitution, namely, that it is the only government in the world which 'united public strength with individual security." "

But this was not all. In this speech he paid a high tribute to the British House of Lords as "A most noble institution."

But this wasn't enough; he had proceeded: "The hereditary interest of the King" (in England) "was so interwoven with that of the nation, and his personal emolument so great, that he was placed above the 
danger of being corrupted from abroad, and was at the same time both sufficiently independent and sufficiently controlled to answer the purpose of the institution at home."

Madison, whose truthfulness, as far as I know, has never been elsewhere denied, says that his report of this speech, "as above taken down and written out, was submitted to Hamilton, who approved of its correctness, with one or two verbal changes, which were made."

Mr. John C. Hamilton, son and biographer of Hamilton, as a part of the general attempt to suppress this chapter of American history, does question his veracity in a roundabout way by calling his report "a very imperfect report of the speech," etc. This statement he attempts to support by comparing the speech with a brief of it, or a brief of some undated speech, found among Hamilton's manuscripts in his handwriting.

Here are a few lines from the brief itself, if properly it can be called a brief. It is rather "head-notes" of this or some other old speech, just like head-notes that any one would make upon the back of an envelope, when he had a few minutes and wanted to outline the scope of an extemporaneous argument. See how these headnotes in Hamilton's handwriting demonstrate the wonderful accuracy of Madison's long-hand report. They read:-

"Here I shall give my sentiments of the best form of government - not as a thing attainable by us, but as a model, which we ought to approach as near as possible."

"British Constitution best form." 
Then he puts down the names of "Aristotle, Cicero, Montesquieu, and Necker," evidently as supporting authorities, from whom he proposes to fortify his argument. Then these head-lines:-

"Society naturally divides itself into two political divisions the few and the many, who have distinct interests. . . .

"If government is in the hands of the few, they will tyrannize over the many. ... .

"If (in) the hands of the many, they will tyrannize over the few. It ought to be in the hands of both; and they should be separated. . . . (That is, two Houses)

"This separation must be permanent. . . .

"Representation alone will not do. . . ."

The next - and this is the milk in the cocoanut:"And if separated, they will need a mutual check."

And clinching the nail:-

"This check is a monarch."

From the next we learn that this monarch ought to be "hereditary." From the next that the advantage of a monarch is that he is "above corruption," and is "not subject to foreign influence."

I do not want to quote all the head-notes of the speech, but letting escape a few that are non-essential to the argument right here, there follow these two:-

"It is said a republican government does not admit a vigorous execution.

"It is therefore bad; for the goodness of a government consists in vigorous execution."1

Hamilton here made a mistake, which so many people - Pope, among others - make, of regarding efficiency

${ }^{1}$ See "Life of Hamilton," by John C. Hamilton, Vol. 3, page 280 et seq. 
of administration as the main end of government. It is a thing that ought to be had, as far as can be, consonantly with liberty and local self-government, but it is not the only, nor is it the chief, nor anywhere near the chief, end of government. That government is " not" "best, which is best administered."

Thus Madison's report of the speech made from these notes, while it was not verbatim - Madison not being a shorthand reporter - was evidently faithful, and was a report which Hamilton could not have quarreled with. An examination of Yates's Minutes in Elliott's Debates, shows that his report of Hamilton's remarks agrees substantially with Madison's and with the notes.

It will be noted that these head-notes are replete with Hamilton's distrust of anything like democratic institutions, and endorse a House of Lords and a King as things to be approximated, and are pregnant with the thought that all government must be maintained by tying to its purposes the self-interest of those, who constitute its governors. They must be so "highly rewarded," as to be "above corruption"; the assumption being, that, if not, they necessarily will be corrupted.

Now, of course, Hamilton's plan did not prevail in the Constitutional Convention. Every material proposition made by him was voted down. But I am demonstrating his reactionary and counter-revolutionary desire, which is always one step from a design.

In Hamilton's plan, offered to the Constitutional Convention, the Senators were not to be elected by the people at all, but by electors, and these electors each had to have at least a life estate in land, or a leasehold 
estate for fourteen years. Senators were to hold their seats for life, unless impeached, and it was the Senate, which was to declare war, as well as ratify treaties, and control appointments. If any man of the utmost audacity could have had audacity enough to propose to the plain American people a plan more essentially aristocratic than that, it would be curious to hear it. His President was to be elected only by such part of the people as had an inherited estate in fee simple, or for a tenure of three lives, or a clear personal estate of a thousand Spanish dollars, and even these were not to vote for the President, but for electors, and the electors, by sealed ballot, for the President. Then the electors of each State were to select second electors, and these second electors were to carry the ballots to the Chief Justice, and, in his presence, open them.

The only advantage about the scheme was that this complicated process, with which the people had so little to do, was not to trouble them very often, for Hamilton's President was to hold his office for life, unless impeached. Besides having the powers which our President has as chief executive of the nation, Hamilton's President was to appoint all the governors of the States. His Federal Government was to designate all the State judges, or rather Federal judges in the States, vested with substantially the entire judicial power of the country. Then, in order that his House of Representatives might not be troublesome, it was left to the President to convene and prorogue Congress!

Jefferson has been accused of being unjust to Hamilton because he said the latter "favored a king, lords and commons." If this plan was not substantially 
and really one for not only a king, but a Polish or elective life king at that, and a substantial house of lords, except that the king and lords were not called by those names, and were not as yet hereditary - only holding at first for life - it would be hard to find anything that is. Moreover, there was virtually no "commons" at all.

Notwithstanding the fact of the defeat of his plan of government, he still advocated the adoption of the Constitution, as submitted, because, although it was not in accord with his design, it was the best attainable for him - much nearer his model than the old confederacy - and, although "an experiment," was worthy of a trial. Moreover, it was elastic, and could be stretched in the working. Nor did his view, bent, or design cease with the adoption of the Constitution. If so, when?

His friend, Morris, wrote to Robert Walsh in a letter dated as late as February 5, 1811:-

"General Hamilton had little share in forming the Constitution. He disliked it, believing all republican government to be radically defective. He heartily assented, nevertheless, to the Constitution, because he considered it a band, which might hold us together for some time, and he knew that national sentiment is the condition of national existence."

Wise and far-seeing sentence this. Then Morris adds, speaking still of Hamilton: "He trusted, moreover, that in the changes and chances of time, we should be involved in some war, which might strengthen our union and nerve the executive."

From his standpoint, of course, some "temporary band," which was "to hold us together," had to be 
adopted. No union could become consolidated, nor be "strengthened" and rendered more "stable," either in peace, or "if involved in some war," unless it first existed.

In a letter to Gouverneur Morris, dated February 2, 1802, Hamilton says:-

"Mine is an odd destiny. Perhaps no man in the United States has sacrificed or done more for the present Constitution than myself; and, contrary to all my anticipations of its fate, as you know, from the very beginning, I am still laboring to prop the frail and worthless fabric. . . . Every day proves to me more and more, that this American world was not made for me. ... You, friend Morris, are by birth a native of this country, but by genius an exotic. You mistake, if you fancy that you are more of a favorite than myself, or that you are in any sort upon a theatre suited to you."

"Your people, sir," exclaimed Alexander Hamilton at a public dinner in New York, smiting the table with his fist, "Your people, sir, is a great beast!" He was not the only one of the reactionaries, who held and continued to hold that opinion.

In the letter from Morris to Walsh, dated February 5, 1811, already partially quoted, Morris says: "One marked trait of the General's character was his pertinacious adherence to opinions he had once formed. ... He never failed on every occasion to advocate the excellence of, and to avow his attachment to, monarchical government." Morris adds: "By this course he not only cut himself off from all chance of rising into office, but singularly promoted the views of his opponents," etc. (He means, of course, elective office.)

"Singularly promoted the views of his opponents." 
How? By establishing the truth, which they asserted most openly always, and which many Federalists denied then, and all later, that there was "a monarchical party;" that is, a party anxious to instill a monarchical spirit into the American frame of government, even though (which would itself become doubtful after a while) its outward republican frame were to be maintained. And this same Morris, in a letter to Aaron Ogden, dated December 28, 1804, says:-

"Our poor friend Hamilton bestrode his hobby to the great annoyance of his friends, and not without injury to himself. More a theoretic than a practical man, he was not sufficiently convinced that a system may be good in itself, and bad in relation to particular circumstances. He well knew that his favorite form was inadmissible, unless as the result of civil war; and I suppose that his belief in that, which he called an approaching crisis, arose from a conviction, that the kind of government most suitable, in his opinion, to this extensive country, could be established in no other way."

Then Morris, a reactionary too, and partially sympathetic with these views, adds:-

"Experience alone can incline the people to such an institution. That a man should be born a legislator is now, among unfledged witlings, the frequent subject of ridicule. But experience . . . will tell us that men destined from the cradle to act an important part will not, in general, be so unfit as those who are objects of popular choice.".

"But," it is said, "these were theoretical views." Yes, after the holders of them were whipped out of the political arena. Where a man's real faith is, there are his works. What the heart wills, the head will find it hard not to have the hand try to do. A bad theory and an imitative practice dwell in a double room, with sliding doors between. 
Men entertaining such "theoretical" opinions were not at all apt to keep a republican spirit in republican institutions, much less to go further and put a democratic soul-politic into a republican body-politic, and Jefferson knew it. He wanted not only to republicanize, but to democratize, and he did it, and his election in 1800 deserves to be mentioned in history as our second revolution.

Jefferson used to say, that if "the hoards of letters now in private keeping" should ever be published, they would justify his suspicions and prove that his contentions were not ill founded. I think the student will conclude from what have already been published, that he was not lacking in foresight. How many have been suppressed? God alone knows! Hamilton's own son, in his "Life of Hamilton," seemingly without appreciating it fully, published many of the letters which establish it. Fisher Ames has left letters behind that speak loudly; so has Plumer, so has George Cabot; also Christopher Gore, and Timothy Pickering; and Thomas and Theodore Dwight, not only letters, but public documents. Fisher Ames says, that the American people trying to govern themselves "without separate orders" reminded him of "free negroes!" See this delightful specimen of the antique in Ames's "Works," Volume 1, page 393, and another letter on the next page to Timothy Pickering, the last dated February 4, 1807. Then read the private letters of Theodore Sedgwick, sometime Federalist "Leader" on the floor of the House of Representatives, chosen to lead by his fellow reactionaries - especially a letter to Hamilton of January 27, 1803- "Hamilton's 
Works," vol. 6, page 552. Then, do not forget that pussy-footed old Counter-Revolutionist, Oliver Walcott. Much has been said about the conversation which Jefferson in his Ana recorded as having occurred between John Adams and Alexander Hamilton, from which Jefferson drew the inference that Hamilton was not only in favor of a monarchy, but of a "monarchy bottomed on corruption." I believe that the report of the conversation is almost literally accurate, although there is, of course, a distance, long or short, between a man's praising a thing and his wanting to put that thing into operation at a given time, or in a given place. The conversation was this: Mr. Adams said, speaking of the British Constitution: "Purge that Constitution of its corruption and it would be the most perfect constitution ever devised by the wit of man." Now a man, who will read Adams' work, "Davila," his "Defense of the American Constitution," and his letters, and will not arrive at the conclusion that at one time Mr. Adams not only entertained, but actually printed, just the view here attributed to him, is much lacking in impartiality or perspicacity, or intellectual integrity one or all of the three. And Mr. Adams is not the only man, who entertained then, or entertains now, that opinion. Probably twenty per cent at least of my readers do. I entertained it once. In fact, I remember going further, and, enraptured with the glowing rhetoric of Edmund Burke, coming by an eloquent, if not a wise route, to the conclusion that even the rotten borough system in England was a blessing - a sort of fortress for conservatism.

Now what is it that Jefferson reports Hamilton as 
replying? "Hamilton paused, and said: 'Purge it of its corruption and give to its popular branch equality of representation, and it would become an impracticable government."" The word Jefferson used was "impracticable." It was the giving to "its popular branch equality of representation," which was the thing that would make it "impracticable." Remember at the same time that as the British Government was then practically administered, it was the unequal representation illustrated by "rotten boroughs," like the "Chiltern Hundred," that furnished the means of "management" and control by the British executive. The "conservative classes" always - the ministry nearly always - controlled these boroughs.

Then Hamilton continued in these words: "As it stands at present, with all of its supposed defects, it is the most perfect government which ever existed." Now Jefferson has been charged with "attributing evil motives" because he recorded this expression of Hamilton's, when, with the debated exception of our own government, everybody will assert that the English Government, "just as it stood" in Hamilton's day, with all its admitted corruption, was "the most perfect government" in its "practical" workings, "which had ever existed" up to that time. No man was guilty of a crime, or treason, or an "evil motive," because he believed, what so many then believed, including Montesquieu and Necker. I am as certain that Hamilton said it, as I am that Edmund Burke, if seated at the same table, would have said the same thing, and I draw no inference of personal corruption in either case. Go back and study your Burke, and then study the 
literature of the opposition to the English reform bill. "Whatever is old in years, to man is Godlike."

Hamilton, having in his mind that the House of Commons had to be "managed," as the ministers of Great Britain called it, would have been wiser than he, with his distrust of this "great beast" - "the people" - with his lack of imagination and original constructiveness, could have been expected at that day to be, if he had not likewise thought, that our House of Representatives would have to be "managed" in order to keep our new government from being "impracticable." Now remember that, in this quotation, Jefferson does not accuse Hamilton of being personally corrupt, or of any other vice, or crime, or fault, save that of opinion. Jefferson wrote of him in these same mémoirs; "Hamilton was indeed a singular character. Of acute understanding, disinterested, honest and honorable in all private transactions, amiable in society, and duly valuing virtue in private life, yet so bewitched and perverted by the British example, as to be under thorough conviction, that corruption was essential to the government of a nation." Old Sir Robert Walpole, a thoroughly honest man personally, was under precisely the same "thorough conviction," and Hamilton's whole policy convinces me that he was too, with this difference: that Hamilton would perhaps not have bought a man's vote outright, as Sir Robert made no bones of doing. But he counted it a public gain when, by giving a position in the Treasury to a man here, or interesting a man there, as a director or stockholder of the United States Bank, or as a holder of public funds, he had secured in the representative assembly an 
adherent of "government," as he called it. The chief aim of his policy was to marry interests to the government, and it was to be done by management and legislation. He deemed it necessary and wise; Jefferson did not. The latter saw corruption in its effect, whatever its intent. Hamilton deemed Jefferson a hypocrite, when he professed that he wanted to "bottom government" on reason and the popular will alone. Indeed, half the politicians today, though they profess - as Hamilton did not - allegiance to Jefferson's principles, do not entertain them, and being conscious hypocrites themselves, conclude that those, who do not only profess, but believe them, are in the same class with themselves.

Hamilton became the idol of the monied class. It was no wonder that Fisher Ames, who understood him and his policy, wrote to him on July 31, 1791, a letter which can be found in Hamilton's "Works," Volume 5, page 473 , containing these words:

"All the influence of the moneyed men ought to be wrapped up in the union and in one bank. . . . The success of the government of the United States, and especially measures proceeding from your department has astonished the multitude."

Poor old multitude! As usual, all it got out of it was astonishment! Nearly, or quite, half of us have come by now to know, that the very A B C of political reform must consist in the divorce of government from "big business" and of "big business" from "big politics," and, therefore, it looks corruptive, if not corrupt, to us, as it did to Jefferson, so far in advance of us, that a man should pursue a persistent plan of marrying them together. But it was different then. We are to remember that in Hamilton's and Jefferson's day 
even the proud Earl of Chatham - the elder Pitt - in his somewhat contemptuous way, to be sure, but none the less actually - coöperated with the Duke of Newcastle, in "carrying on His Majesty's Government." Pitt, the Empire-builder, uttered day by day words of eloquent wisdom and initiated great measures of statesmanship. Newcastle, day by day, "managed" the House, in a notoriously corrupt way, to which Chatham could not have been blind. He despised the system and Newcastle both; but he accepted both as "something that was and is and must be," in order that he and the soldiers and sailors of Great Britain might lift up her Empire, enlarge her trade, and even extend the empire of liberty for the human race. He had to have a fulcrum on which to rest his lever - a parliamentary majority.

There is no doubt about the fact that General Washington believed that the monarchical party had quit struggling, after the adoption of the new Constitution. There is equally no doubt that, as to a great many of them, he was, as Jefferson told him, mistaken.

Designs, or desires, like these seem so absurd from our present viewpoint, that it is hard for anyone to put himself back in history to the place, where they were not only actual, but natural.

The reader is better prepared now, I hope, to understand the situation of things in Washington's Cabinet, and to understand Jefferson's purpose, and how he came, little by little, to be the head of a great democratizing party - "The Democratic-Republican" Party - not Republican alone.

Hamilton intended that the "Treasury Measures" 
should have another effect besides that of "strengthening the public credit." They were to tie vast monied interests to "government" (and remember that the word "Government" was then much used in the English sense - of administration). In this connection, I recommend the following utterances from Senator Lodge's "History of the United States" in the "History of Nations" series, which occur in comment upon Hamilton's scheme for Federal assumption of the State debts: "This final proposition, not only was wise financially, as it was intended to be, but was also a powerful instrument of consolidating the government." Note that this is just what Jefferson said it was intended to be.

Hamilton was watchful of the government itself, lest it be weak enough to chance being overthrown by the people, and was anxious to buttress it strongly ınvoking to its aid every "influence" and "interest" possible. From Jefferson's viewpoint, the things to be buttressed were the elemental and natural rights of the people as individuals and the great safeguarding right of local self-government - and the chief peril against which these were to be defended was the government itself.

On page 353, from the same book, by Senator Lodgea thorough Hamiltonian, by the way - occurs this language in connection with Hamilton's scheme for a national bank: "In this connection it ought to be repeated that aside from financial consideration, Hamilton had ulterior motives in wishing the national government to engage in the banking business and to assume the State debts. He saw clearly that both would strengthen the national government, by rallying 
to its support the monied interests of the country," etc. If he had added right here, "and of getting members of Congress and Senators, who held or bought up public securities, interested in governmental measures," he would have made a full statement of the case.

No Federalist, or modern Republican, ever regarded such a motive as the one stated by Senator Lodge to be an evil. From their standpoint, it is a wise and statesmanlike motive. From Jefferson's viewpoint, it necessarily tended towards plutocracy, or corruption, or both. Nor did Jefferson think such measures necessary to "strengthen the public credit."

Even Foster, in his "Century of American Diplomacy," page 149, says: "In September, 1789, Mr. Jefferson reported from Paris to Secretary Jay that the credit of the United States at Amsterdam had become the first on that exchange; . . . that our bonds had risen to 99." Note that date and how soon after the establishment of our government. What did Hamilton's treasury schemes, yet unborn, have to do with that? As far as foreign and domestic evidences of the United States debt were concerned, domestic tranquility, an established and stable government, with power to tax individuals, so as to have a treasury with money in it, the consequent ability to pay, and the immediate illustration of that ability, by promptly meeting interest and arrears, would have brought them to par anyhow.

In one of his anonymous newspaper articles, Hamilton charged that Jefferson was "originally and continuously an opponent of the adoption of the present Constitution of the United States." How absolutely 
untrue this accusation is we shall now see - the inquiry being pertinent to the democratization of our Federal Institutions. Jefferson objected that the Constitution did not sufficiently guarantee the preservation of individual rights - "the inherent and inalienable rights of the people" - which had been protected in Great Britain by a Bill of Rights, and that a Bill of Rights ought to be embodied in our Constitution. This was done. Jefferson also desired to have engrafted upon the Constitution a provision declaring that the Federal Government had no powers except those granted it (either expressly or by necessary implication), and that all other powers were "reserved." This was done. Now the chief business of a bill of rights is to protect the individual against unjust governmental action. The authors of the Federalist do not seem to have realized very intensely the importance of that, and yet, in so far as the judiciary has found in the Constitution a bulwark of protection for the people against the despotism of the Government, or of popular majorities, as in the case of the civil rights bill and some other Reconstruction legislation, and many other enactments violative of natural, or property, or labor rights, this bulwark has consisted mainly in the amendments to the instrument, secured by Jefferson and others of his school, and not in the original instrument, as presented for adoption in the first instance.

In Number 84 of the Federalist, bills of right are referred to as "aphorisms!" One may imagine how this sort of expression would grate on the feelings of a man like Jefferson, who had not been influenced by the American counter-revolution. In the same number of 


\section{PERMANENT INFLUENCE OF JEFFERSON}

the Federalist, it is argued that under our government "the people surrender nothing; and as they retain everything, they have no need of particular reservations." The fact that we still hear so much about the "inherent powers" of the federal government, even after the adoption of the amendment declaring that "powers not delegated are reserved to the States, or to the people," proves that the author of Number 84 of the Federalist was wrong and Jefferson right.

In answer to much that I have said of the Hamiltonian views and desires, or designs, his articles in the Federalist might be quoted, but in these articles, one finds not the political philosophy of Hamilton, but an advocate's plea for the adoption of the Constitution. That Hamilton gave it even this support is a tribute to his devotion to the central and primordial necessity of a union, and is a manifestation of intellectual ability seldom excelled.

Still, the papers in the Federalist show that what he and Jay most dreaded were popular movements. They would have been surprised, if they could have known that a hundred and thirty years afterw?rds our Federal Government would be, in its actual working and legislative results, the least responsive of all governments over English-speaking peoples to the result of a popular election. They would have been still more surprised, if they could have known that the English Government and all the English colonies, at the end of that time, would furnish systems, where the executive itself would be merely the mouthpiece of a committee of a majority of the legislative representatives of the people; that within that time the House of Commons in 
England itself, and its imitation parliamentary bodies in all British colonies, would wield not only full legislative power, unchecked by executive veto, but full executive power, and that perhaps the most remarkable movement in the United States of the present day might be characterized as a reaction from the realization of the fact that this is far from being the case with us a reaction so violent, as to cause many patriotic men to advocate the absurdity of government by popular plebiscite; so true it is always that "the best cure for the evils of democracy is more democracy;" only it must be democracy, developing of itself gradually and sincerely, through the free play of representative institutions; and, even then, it can find its only secure basis in popular education and the general diffusion of information.

Jefferson also at first wanted an amendment to prevent the Executive from being indefinitely selfsuccessive. I think few of us in this year of our Lord's grace will challenge his position in this regard. $\mathrm{He}$ at first wanted one term of seven years. Then later he writes: "Indeed, since the thing is established, I would wish it not to be altered during the life of our great leader [that is, Washington], whose executive talents are superior to those, I believe, of any man in the world, and who, alone, by the authority of his name and the confidence reposed in his perfect integrity, is fully qualified to put the new government so under way, as to secure it against the efforts of opposition. But, having derived from our error all the good there is in it, I hope we shall correct it, the moment we can no longer have the same name at the helm." The 
italics here, as always in these lectures, are mine and indicate what I believe to be the truth; that not only in Mr. Jefferson's mind, but in the minds of many others, the indefinite reëligibility of the President owed its place in our Constitution to the certainty that the first President would be George Washington, and that no term ought to be fixed for him, until he had taught the Government "how to march." In his older age, after retirement, Jefferson congratulated himself upon the fact that Washington's example in refusing a third term, and his own imitation of this example and the reasons which he gave for it, would constitute a sort of unwritten law. This it has thus far been throughout all of our history, no President ever having sought reëlection beyond the second term, except Grant, who was rebuked by his own party, and Roosevelt, who was rebuked by both parties.

As usual, however, Jefferson's own language best expresses his position and motives. In a letter to John Taylor of Carolina, he says:-

"My opinion originally was that the President of the United States should have been elected for seven years, and forever ineligible afterwards. I have since become sensible that seven years is too long to be irremovable, and that there should be a peaceable way of withdrawing a man in midway who is doing wrong. The service for eight years, with a power to remove at the end of the first four, comes nearer to my principle as corrected by experience; and it is in adherence to that, that I determine to withdraw at the end of my second term. The danger is that the indulgence and attachments of the people will keep a man in the chair after he becomes a dotard, and that re-election through life shall become habitual, and election for life follow that. General Washington set the example of voluntary retirement after eight years. I shall follow it. And a few more precedents will oppose the obstacle of habit to any one who 
after awhile shall endeavor to extend his term. Perhaps it may beget a disposition to establish it by an amendment to the Constitution."

Also these words by Jefferson ought to be remembered by everybody in connection with the Presidential tenure: "If some period be not fixed, either by the Constitution, or by practice, the office will, though nominally elective, become for life and then hereditary." This doesn't seem so "timid" to those of us, who have just actually witnessed an attempt to be elected to what he himself has publicly counted as a third term, made by a man, very popular and able, who has never answered the question, whether, at the end of that time, he would be a candidate for a fourth term, nor whether at the end of the fourth, he would be a candidate for a fifth. People who laugh at Jefferson's "suspicions" and "fears" and "credulity," etc., only have to wait long enough for their posterity to laugh at them. Our office of President would probably be as Jefferson at first feared it would be "but a poor edition of a Polish king," save for the example set by Washington and the reinforcement of this example by imitation and the clear statement of the reasons for it given by Thomas Jefferson. If we had begun by electing any one - even Washington - as long as he lived - even if this had been for only one more term he dying during the period of a third - the precedent of electing men indefinitely would doubtless have been followed in the case of every popular man; undoubtedly in Jefferson's case, if he had permitted it, and later on in the case of Andrew Jackson, still later in the case of Grant, and still later in the case of Roosevelt; if these men had ever gotten to be Presidents at all; a question- 
able thing but for the contrary precedent. How long it would have taken reëlections to become mere matters of form, is, of course, a matter of speculation, but that, sooner or later, they would have become so, is a matter of certainty.

An indefinitely self-successive executive, easily turned into a dictatorship, has been the rock upon which the so-called South and Central American "republics" have split, and the good sense of the American people in taking the advice of Washington and Jefferson has saved our institutions from a like death of the spirit. They will never be safe, until a constitutional amendment shall be passed, confining the Presidential term preferably to a term of eight years, with the right of recall by the people in the middle of the period; that is, two four-year terms, or else to one term of six or seven years. Thus far the people have said: "Washington would not, Jefferson would not, Grant could not, and nobody else shall," but the danger is ever present, as long as there are adventurous and ambitious and able men, conjoining to their courage and ambition and ability great popularity, in a word "men of the hour" - dangerous in a "crisis." Unpopular men, of course, have never been dangerous to free institutions anywhere.

Institutions are what practice makes them. Washington and Jefferson never performed a greater service for the permanency of American institutions than this. In Jefferson's time our institutions were still subject to this danger. The people seemed not fully awakened to it. Eight State Legislatures had passed resolutions endorsing Jefferson for a third term. More would 
have followed, if Jefferson had not discouraged it. Even Senator Lodge says there is no doubt he could have had it. Washington's precedent and Jefferson's ratification of it have constituted what has frequently been called a part of "the unwritten constitution of the Republic," like the Monroe Doctrine. The words in which Jefferson clothed his declination are wise and patriotic beyond measure: -

"That I should lay down my charge at a proper period, is as much a duty as to have borne it faithfully. If some termination to the services of the chief magistrate be not fixed by the Constitution, or supplied by practice, his office, nominally for years, will, in fact, become for life; and history shows how easily that degenerates into an inheritance. Believing that a representative government, responsible at short periods of election, is that which produces the greatest sum of happiness to mankind, I feel it a duty to do no act which shall essentially impair that principle; and I should unwillingly be the person who, disregarding the sound precedent set by an illustrious predecessor, should furnish the first example of prolongation beyond the second term of office."

However, already in Washington's time, the third term, with its indefinite tenure of executive office had failed the counter-revolutionists, as a political recourse. They could no longer shield themselves behind the great name and character of George Washington. He had retired in spite of all solicitation and protest. The Federalists must now fight their battles in the open. John Adams became their candidate - a man, who whatever his faults, was, as Jefferson once said of him, "as disinterested as the Being who made him." No other leader on the other side was thought of but Jefferson. Adams defeated him by three votes in the electoral college. Even at that, three electors from 
States, whose people had voted for Jefferson, voted for Adams. He never uttered a complaint. Jefferson feared nothing actively counter-revolutionary in the way of overturning our government by force from Adams personally. His confidence was justified.

Jefferson was elected Vice-President. He carried with him to Washington a commonplace book of memoranda of parliamentary rules and practices. Out of it he constructed what we call "Jefferson's Manual" - a manual of parliamentary rules and practice, yet the guide of the Senate and one of the guides for the House. It has permanently affected our parliamentary practice, and thus the practical working of our institutions.

Meanwhile the war of ideas went on. Francis Walker says very advisedly:-

"The blunder of the Federalists in enacting the sedition law was not an accidental one. On the contrary, it was thoroughly characteristic. It sprang out of a distrust of the masses; a belief that the people must always be led or repressed; a reliance on powers, estates and vested interests; a readiness to use force - all of which were of the very essence of the aristocratic policies of the last quarter of the Eighteenth Century."

At another place in Mr. Walker's very readable book, referring to Jefferson's final victory, occurs this language:-

"The reliance upon estates and powers within the commonwealth, which was of the very essence of Hamilton's philosophy of government, and in which even Washington and John Adams shared; the disposition to resort on one side to the influence of wealth, and on the other to intimidation and repression for checking the violence of political discussion: these things were to disappear and disappear 
forever from American public life, for good or for evil, but altogether, as we may well believe, for good, in the large and long result."

"Whom the gods would ruin, they first make mad." The Federalists helped Jefferson in his fight. They travelled at a reckless pace in their reaction against democracy. Alien and Sedition laws were working to a result contrary to their intent. As usual, unless accompanied by overwhelming force - so great as to cower men - governmental tyranny stimulated the love of liberty. French aliens fled from the country. The Irish - nearly all republicans and specially persecuted - had no country to flee to. It hadn't been long since Emmett was executed.

I have already referred to the Freneau incident. A part of Secretary of State Jefferson's letter to Washington concerning Freneau, is pertinent to the later Federalist attacks upon the liberty of the press. In it he administers this mild reproof :-

"As to the merits or demerits of his [Freneau's] paper, they certainly concern me not. He and Fenno are rivals for the public favor. . . . No government ought to be without censors; and where the press is free, no one ever will [be]. If virtuous, it need not fear the fair operation of attack and defence. Nature has given to man no other means of sifting out the truth, either in religion, law, or politics. I think it is as honorable to the Government neither to know, nor notice, its sycophants or censors, as it would be undignified and criminal to pamper the former and persecute the latter."

I think this last sentence is one of the grandest ever penned, and if it contained a suggestive admonition to the Father of His Country himself, I do not the less value it for that. Even "fathers of their countries," if sincere republicans, must put up with free speech and 
free printing, subject only to the restraints of the ordinary laws of slander and libel.

The alien law gave authority to the President to banish from the country "all such aliens as he should judge dangerous to the peace and safety of the United States!"

Jefferson can never receive sufficient praise for having fought these measures, and measures like them, through his friends upon the floor of the two Houses, and, finally, by calling into action the protestant powers of the States.

A part of the permanent influence which he has exercised upon American institutions consists in the fact that, after he had completed his work of antagonism to this legislation, nothing like it has ever since been attempted, except once in a smaller way, during President Roosevelt's administration, when it was sought to revive the spirit of the sedition laws by invoking the aid of the judicial power of the United States to punish certain newspapers for having printed so-called malicious things against the national administration and public officials, and against the go-betweens interested in the French Canal-Bond-Sale. A just judge refused to be used. There is happily no such thing known as yet to our institutions as "libelling the Government."

As to the alien laws, the Chauvinism which constituted the spirit of them was revived by the Whig leaders of the so-called "Know-Nothing" movement, but though it looked for a while like a prairie fire, fated to sweep all before it, the party of Jefferson remembered, even then, enough of his teaching to extinguish the flames. 
The most fortunate thing for the country that happened in Adams' administration was that the war with France, for which we had made such great preparations, did not occur. General Washington was appointed commander in chief and Hamilton second in command. If the war had come, the work of democratization would have been halted, perhaps for a time, perhaps for all time. But there is little doubt in my mind of the fact that it would have made Hamilton's choice the next President of the United States and himself virtually political dictator. There is equally little doubt of the fact that Hamilton would have used his great power, as the glorified commander of a successful army, for the purpose of rendering the government stronger, or "more stable," as he would have expressed it. He would have led our army against the Spanish colonies in Florida, or Mexico, as the Miranda correspondence and negotiations prove. In fact, it is hard to see what we wanted with an army, if our only purpose were to fight France. As long as she was at war with Great Britain, she could not land a regiment upon the American continent, nor did we want to land one in Europe. There was and could be literally nothing French in America to fight on land.

H. C. Merwin, a very moderate man and a very fair one, speaking of the time of our anticipated war with France under Adams' administration, writes:-

"Hamilton was not the man to overturn the govenment out of personal ambition, nor even in order to set up a monarchy in place of a republic. But he had convinced himself that the republic must some day fall of its own weight. He was always anticipating a 'crisis,' and this word is repeated over and over again in his cor- 
respondence. It even occurs in the crucial sentence of that pathetic document which he wrote on the eve of his fatal duel. When the fatal 'crisis' came, Hamilton meant to be on hand; and, if possible, at the head of an army."

Nothing can account for the fanatical hatred visited upon Adams' head by Hamilton and the other chief Federalists, because of his wise and patriotic act, unless it be, that it balked deeper and further designs. Nothing was left to fight France about. The amende honorable had been made, our demands upon her had been acceded to. Adams was glad of it. The country was glad of it. Peace ensued.

Meantime there had appeared upon the sceneflitting ghost-like, in and out, first on one and then on the other side of the Atlantic, conferring with the younger Pitt and with Rufus King, our Hamiltonian Ambassador in London, and corresponding unrebuked, indirectly, and then directly, with Hamilton, and later with President Adams, who, in his honesty and patriotism, sat down on him extinguishingly - one Miranda - a Spanish-American of Caracas. For all of which see Hamilton's, King's, and Pickering's letters, but above all the Edinburgh Review, Volume 13, pages 287, 289, et seq., and study Miranda's subsequent connection with Aaron Burr.

But for this peace with France, there would have been effected the British alliance proposed by Hamilton in Washington's Cabinet, and of which Washington had said, "the remedy is worse than the disease"; a large army would have been put on foot, with Hamilton at the head of it, and probably the "crisis" might have happened! 
Meanwhile, what John Randolph called the "American reign of terror" was arousing more and more indignation, and the project of raising an army, when taken in connection with the alien and sedition laws, was arousing fears. The Republicans knew that the counter-revolutionary alarm about "a French invasion" was manufactured to furnish a reason for raising an army, and that the army might be used, in a way dangerous, at any rate, to the Republicans - if not to the Republic. The officering of the army did not decrease this excitement. It was known that Washington could be only nominal chief, if active operations in the field had to take place; that Hamilton would be the real chief in command, and that his assistant officers - every one of them-were Federalists. Free speech and free printing had been already attacked, judges on the federal bench were already making political harangues against "democracy" to grand juries and petty juries, so that you may imagine the situation. None of this distrust and anxiety was lessened by the fact that Hamilton was not a popular man - did not, in fact, dare to run for an elective office - was "generally beaten in his own State," and, therefore, was popularly supposed to be willing to make an attack upon the elective system.

The country was at white heat. The Virginia and Kentucky Resolutions, as State protests, were flung into the ring. The repetition in them of the thoughts of the Declaration of Independence had an admonitory, if not an ominous sound.

That Hamilton contemplated the use of force is inferrible at least from his letter of advice to his 
followers in Congress at the beginning of the Congressional session of 1798-1799. Read this: "Our military force should be kept upon its actual footing; making provision for a reinlistment of men for five years, in the event of a settlement of differences with France. ... The laws respecting volunteer companies and the eventual army should be rendered permanent, and the Executive should proceed without delay to organize the latter."

His scheme went still further. He advised legislation, or amendments, whereby the large states should be subdivided by Congress into two or more states each. This was aimed at Virginia and Pennsylvania both democratic and strategically situated to oppose an armed administration at Washington.

This is significant and is a tribute to Hamilton's foresightedness, in view of what afterwards occurred, because it looked, for a little while, after Jefferson's election by the people, as if unconstitutional methods might be adopted to seat a Federalist and to keep either him or Burr from being seated. The Governors of Virginia and Pennsylvania, therefore, began to mobilize their armed forces with the view of protecting a convention of the States to be called, in such an event, by the President and the Vice-President elect, as proposed by Jefferson, and of enforcing whatever measure of settlement of the issue it might decree.

If Hamilton's scheme of having Congress subdivide the large States could have been acted upon, the two great middle states might have been rendered harmless to the Federalist party and helpless for the defence of popular liberty and the enforcement of the 
right of election. Again, if Hamilton's standing army in times of peace (for he advises its organization "in the event of a settlement of differences with France") could have been put on its feet, the Federalists could have defeated the will of the people by force, notwithstanding Virginia and Pennsylvania.

Here is another excerpt from his letter of advice to the Federalists, as if alien and sedition laws had not maddened the people enough:-

"Fourth. Laws for restraining and punishing incendiary and seditious practices. It will be useful to declare that all such writings, etc., which at common law are libels, if levelled against any officer whatsoever of the United States, shall be cognizable in the courts of the United States. To preserve confidence in the officers of the General Government, by preserving their reputations from malicious and unfounded slanders, is essential, to enable them to fulfill the ends of their appointment. It is, therefore, both constitutional and politic to place their reputations under the guardianship of the courts of the United States. They ought not to be left to the cold and reluctant protection of State courts, always temporizing, and sometimes disaffected."

Nothing has ever been equal, perhaps, to what this last scheme would have resulted in, except what took place in the South during the very worst period of reconstruction. Then the manner in which he finds constitutional warrant for it! Broad implication with a vengeance! The major premise is that an officer of the United States cannot properly attend to his duties unless confidence in him is preserved; whether he deserves it or not! The understood minor is obvious. The conclusion is: "therefore, it is constitutional to make the common law crime of libel, when United States 
officials are alleged to be libelled, jurisdictionable in the federal courts!"

Underlying all of this is the idea that it is dangerous to the social structure for common folks to talk about public officials!

I said above, "whether he deserves it or not," because what are these "common law libels" which were to be "judged in the federal courts," when the plaintiff was a United States official? Turn to your Blackstone and read as follows: "It is immaterial, with respect to the essence of a libel, whether the matter of it be true or false, since the provocation (to a breach of the peace) and not the falsity, is the thing to be punished criminally." So that, therefore, anything, true or false, which brought into contempt or ridicule (by printing or writing or exposing) any civil or military official of the United States, would have been cognizable in a federal court. A political administration, which Hamilton was fond of calling " the government," would have had some eightyodd judges, which Hamilton proposed in this same paper, to create ("at the rate of four for Connecticut"), and, in addition to them, "federal justices of the peace in each county" of the United States, to hunt down and inform against "libellers" of the government. Moreover, these justices of the peace would have been nonsalaried officers, who would have made their living by their fees!

One of the grounds upon which Hamilton places his recommendation of this enormous increase of the Federal judiciary, is that it would bring with it "salutary patronage." It is curious, too, that in this same paper, one reason that he gives for recommending open- 
ing canals and improving waterways is, that "it will be a useful source of influence for the government." Hamilton, of course, did not regard these purposes as corrupt and corrupting, but it is at least natural that Jeffersonians did.

Judges, "at the rate of four to Connecticut," with incidental marshals and clerks "on the side," and United States justices of the peace at the rate of one to a county, would have been abundant, if not "salutary" patronage, and a wide-spread if not "useful" "source of influence" for the Federalist "government."

Is it any wonder that the people thought that the Federalists were looking to two things, to wit: The judiciary and the army, as vehicles for the overthrow of popular liberty?

Hamilton suggests in a letter to Senator Gunn of December 22, 1798, fifty thousand men as the right size of the army. Fifty thousand then would mean eight hundred and fifty thousand now, preserving the ratio to population. The people outside the army would have been as nearly helpless then in the defence of their rights and liberties against fifty thousand trained soldiers, as now they would be against eight hundred and fifty thousand.

In a letter to Harrison Gray Otis, dated January 26, 1799 , he says that he would be glad to see a law empowering the President, if the negotiations with France should not "terminate in peace by the first of the succeeding August," to "declare that a state of war existed" between the two countries, so that he could use the land and naval forces of the United States in the "most effectual way for annoying the 
enemy," and then he suggests this language for the Act: "for preventing and frustrating hostile designs of France, either directly or indirectly, through any of her allies." Spain was then the helpless "ally" of France - chained behind Napoleon's triumphal car.

Here is a request that Congress, abdicating the power to declare war, should empower the President to "declare that a state of war existed," not because a state of war did actually exist, but, as a fiction of the law! Thus anxious was he for war and an army to go with it.

Fisher Ames, a Federalist leader, in a reply to a letter, in Gibb's "Memoirs," Volume 2, page 313, says:-

"... Though you justly remark, it [meaning an army] is no engine of the Government, and the civil magistrate and the process are better ordinary means of self-defence, yet I hesitate to admit that, therefore, the army must not be levied and relied on.... I would have in preparation the force to decide the issue in favor of Government."

Again my reader will notice this use of the word "Government" (not the government) when administration is meant.

Who can say that if we had had war, with such a spirit behind it and such leaders in control of it, the American people would have "come out of it" "as free as they were before" it occurred? Jefferson feared not and expressed his fear. Truly one of the greatest services John Adams ever performed for his country was taking the bit in his teeth, while he ran away to the Peace Goal.

Now mark this next and desperate move of the 
Counter-Revolutionists. The result of the election in New York had demonstrated that Jefferson was to receive its electoral vote. On May 7, 1800, Hamilton wrote an ever memorable letter to Jay, then Governor of N. Y., in which he proposed - notwithstanding the Republican majority in the State Legislature, the members whereof had just been elected distinctly and by previous agreement, to choose the electors of the State - to defeat the will of the people by a scheme, which he proceeded to unfold. It was for the holdover Federalist Legislature to reverse its former action and to have the people vote once more - this time by districts. But let us quote a part of his own language: -

"The calling of the Legislature will have for its object the choosing of electors by the people in districts; this (as Pennsylvania will do nothing) will ensure a majority of votes in the United States for a Federal candidate. The measure will not fail to be approved by all the Federal party; while it will, no doubt, be condemned by the opposite. As to its intrinsic nature, it is justified by unequivocal reasons of public safety.

"The reasonable part of the world will, I believe, approve it. They will see it as a proceeding out of the common course, but warranted by the particular nature of the crisis, and the great cause of social order."

Here is Hamilton's everlasting "crisis" recurring again, and here is the reason given, since the world began, by monarchs and aristocrats, for opposing republicanism and refusing to abide by the result of elections, to wit: the maintenance of "the cause of social order."

Read this letter. It has been spoken of as "remarkable and extraordinary." It is not. It is but a normal 
outcropping of a political system and an anti-democratic creed, in which Hamilton was thoroughly sincere.

Honest old John Jay - amongst whose papers after his death this letter was found by his son and biographer - had endorsed upon the back of it, in his own handwriting, these words: "Proposing a measure for party purposes which I think it would not become me to adopt."

Hamilton's scheme in New York, taken in connection with the scheme to which he refers to throw out the vote of Pennsylvania, by not permitting either its people or its Legislature to vote for Presidential electors - a scheme to be accomplished by a hold-over Federalist State Senate refusing to act at all - would have destroyed all possibility of Jefferson's election, and were both desperate measures. If they had been carried out, the chances are that the American union would have been dismembered. At any rate, civil war must have ensued. The South and West and the people of New York and Pennsylvania would hardly have submitted peaceably to this nullification of Pennsylvania's and this partial reversal of New York's vote. If the Union had been preserved, it would have been preserved at the end of a war, and the Government of the United States, if the Federalists had won, would have come out of that war no longer a government of delegated powers, but a Hamiltonian strong government of assertedly inherent powers, whatever its form. I do not doubt that Hamilton, thinking himself quite a military character, felt assured of Federalist victory. In his very boyhood he had hoped 
for a war, so that he "might gain distinction" and at every opportunity of his life, he displayed absolute confidence in his military genius.

About four years after this time, Gouverneur Morris, Hamilton's truest friend, who knew him better than anybody, in a letter to Aaron Ogden, dated December 28, 1804, speaking of Hamilton, said:

"He knew that his favorite form [of government] was inadmissible, unless as the result of civil war; and I suspect that his belief in that, which he called his approaching crisis, arose from a conviction that the kind of government most suitable in his opinion to this extensive country, could be established in no other way."

The language is that of the cool, cynical, penetrating, observant friend of Hamilton, the man selected by his family to pronounce his eulogy, and whose opinions, as a rule, ran parallel with Hamilton's.

But Jefferson's great task seems done. At least the people vote to endorse him and his gospel: "Back to the principles of the American Revolution." But the great task only seems finished. The Counter-Revolutionists had had their Leipzig. They insisted upon meeting their Waterloo. True Jefferson had been elected, and there was no complaint that it was not by a remarkably honest and fair vote. Yet he, and, what seems never to have occurred to these men, the people, might yet be cheated or bullied out of the fruits of their victory. Not a Democratic-Republican in all the land had voted for anybody but Jefferson to be President. Not a man, however partisan or bitter, pretended it. But again, "whom the gods would ruin, they first make mad." Jefferson and Burr had received the same number of electoral votes. This left the House to determine 
between them. It had no other function. It is to Jefferson's victory over those engaged in this mad attempt to overthrow popular rule and "the voice of the majority honestly expressed," that, next to our independence and the adoption of the present Constitution, with its first ten amendments, our institutions owe most for their permanency and stability and spirit. Had this attempt succeeded, every subsequent Presidential election would have been an invitation to civil war, or a submission to usurpation.

To the spectacle of what occurred attention is now invited. Throughout all this, by the way, Gouverneur Morris seems to have acted honestly and with a gentlemanly appreciation of duty. What is quoted below, he seems to have abided by.

In a letter to Hamilton, on December 19th, he says:-

"It is supposed that Mr. Jefferson and Mr. Burr will have equal votes, and various speculations are made and making on that subject. At first it was proposed to prevent any election, and thereby throw the Government into the hands of a President of the Senate. It even went so far as to cast about for the person. This appeared to me a wild measure, and I endeavored to dissuade those gentlemen from it, who mentioned it to me. The object of many is to take Mr. Burr, and I should not be surprised if that measure were adopted. Not meaning to enter into intrigues, I have merely expressed the opinion, that since it was evidently the intention of our fellow-citizens to make Mr. Jefferson their President, it seems proper to fulfill that intention."

None of the other Federalist leaders, except Huger of South Carolina, seemed to be impressed with that plain homely truth. The Secretary of State, John Marshall, wrote to Hamilton on January 1st that he "had not 
determined" to which of the two, Jefferson or Burr, "preference was due," but that he "could not bring himself to aid Mr. Jefferson!"

Rutledge of South Carolina, a man of extraordinarily high honor in ordinary affairs, wrote: "Should Mr. Jefferson be disposed to make (as he would term it) an improvement (and as we should deem it a subversion) of our Constitution, the attempt would be fatal to us." Now mark the conclusion, which shows the character of "subversion of our Constitution" to which Rutledge was referring: "For he [i. e., Jefferson] would begin by democratizing the people, and end with throwing everything into their hands!" (Italics and exclamation are both mine.) This was such an enormous iniquity that even an honest gentleman like Rutledge wanted it prevented by defeating the known will of the people! It shows that when once the poisonous germ of aristocratic arrogance gets into a man's head, it destroys all vestiges of a moral code in affairs of State.

Fortunately for our institutions and peace, Alexander Hamilton feared and hated Burr, more than he hated Jefferson.

But while trying to persuade all his Federalist friends - and really persuading not one - to vote for Jefferson as against Burr, he did it on the ground that Burr was "a Catiline," and all that. He exhibited neither any motive higher than one of personal choice, nor the slightest indication of a consciousness of the binding obligation on the citizen to obey the will of the nation honestly expressed in a democratic republic.

Neither then nor afterwards did he betray any 
regret, or any consciousness of wrong concerning what he had connived at in Pennsylvania, and attempted to persuade John Jay and the Federalist Legislature to do in New York. He never once took the position taken even by cynical Gouverneur Morris, and much less that taken by Huger of South Carolina who lived and died a Federalist, but a republican to wit: - in Huger's words - that "the people had elected" Jefferson, and that "it was for them to elect a President, and not for me," and that, therefore, he would vote to seat him, over Burr - the only constitutional choice left him being between these two.

The Federalists had their choice between three things, either to elect Burr, or confirm the people's election of Jefferson, or to continue the deadlock, and thereby leave the Government without executive head. In the last event, the plan was for the Federalist Congress to usurp the authority of "reorganizing the Government" by passing a law vesting the chief magistracy in some man of its choice - John Marshall, Secretary of State, being apparently the favorite, though the Speaker of the House, and the President pro tempore of the Senate, all three Federalists, were mentioned.

Jefferson very quietly, but resolutely, denied the right of Congress to "reorganize the government," or "any part of it"; said that no authority existed for the purpose "save in the people themselves," and that "they might authorize a convention to reorganize and even amend the machine." This suggestion of a convention was an insuperable checkmate to the CounterRevolutionists. 
His constant reply to everybody who approached him was that "there were ten individuals in the House of Representatives, any one of whom by changing his vote" could not only relieve the deadlock, but do the will of the people. He said, that if the House of Representatives should elect Burr, he and his party would submit. It had a technically constitutional right to do that, although in doing it its members would commit substantial treason against the known will of the American people. But if they undertook to pass a law, to use his language, "for putting the government into the hands of an officer," that would be clearly a usurpation to which Americans could not submit, and would call for a different and more virile treatment. So, at his suggestion, he and all his friends "declared openly," that "the day such an act passed, the Middle States [meaning Virginia and Pennsylvania] would arm," and "no such usurpation, even for a single day, should be submitted to."

"This first shook them," and then they were completely alarmed at "the ultimate resort" for which Jefferson declared, to wit: "A convention to reorganize the government and to amend the Constitution." Of course, the convention once sitting would have unlimited powers, subject to State ratifications. All that was necessary was to protect it in its deliberations. Jefferson said that "the very word convention gave them the horrors, as in the present democratical spirit of America, they fear they should lose some of the favorite morsels of the Constitution." This declaration and this "ultimate resort" is what really called a first halt upon the Federalist conspiracy to remain in power 
despite the election. Then they tried to get Jefferson to make terms. But here too they failed. In a letter to Monroe, of February 15th, he says: "I have declared to them unequivocally that I would not receive the government on capitulations, and that I would not go into it with my hands tied."

They had pursued the usual course of enemies of democracy and of popular liberty; they had first contemplated a clear usurpation, and - that being balked - they had then attempted to prevail upon the choice of the people, in return for office and emolument, to prove traitor to his constituency by becoming the condition-bound servant of the self-asserted better element.

They thus found themselves confined to the election of Burr, hoping from his gratitude a betrayal of his constituents.

Even to do this they must make a break in the Democratic-Republican phalanx in the House. The House, when voting by States, was a tie.

Jefferson's policy throughout was not only wise and bold, but it was assured, unless some of his own party deserted him for Burr. The Federalists had not succeeded in organizing their army. John Adams's "fool peace" had balked that. The people were no longer afraid. Two great strong States - Virginia and Pennsylvania, strategically situated - had as executives two quietly-determined men, Monroe and McKean, who were mobilizing the State forces in order to protect the convention, which, if need were, would be called by the President-elect, and to which every Republican State, and the Republican voters in the other States, 
would at once send delegates, with such consequence of a thorough democratization of the government as might follow. At every point of the game Jefferson had the counter-revolutionists checkmated.

In a letter to James Madison, dated February 18, 1801, he says: "The minority in the House of Representatives, after seeing the impossibility of electing Burr, the certainty that a legislative usurpation would be resisted by arms, and recourse had to a convention to reorganize and amend the Constitution," were at their wit's ends. Things were brought to an end for them when "Morris, of Vermont, withdrew, which made Lyon's vote that of his State." This was Matthew Lyon, the Jeffersonian, who had served a jail sentence under the Sedition Law.

This Morris was a relative - nephew, I believe - of Gouverneur Morris, to some extent under the influence of the latter, and probably in this particular act actually influenced by him. All the subsequent attempts of Bayard, of Delaware, to take the credit to himself of what occurred, and then to tarnish that credit by claiming that his act of withholding Delaware's vote had been conditioned upon certain promises made by Jefferson, through Smith of Maryland, all of which was denied point blank by Smith; all the claims of Hamilton's friends, that he ought to have the credit, are equally baseless. Bayard quit only when the spectre of a convention frightened him into a semi-paralyzed halt. Hamilton did want Jefferson to beat Burr, and in so far as that is creditable to him, he deserves credit.

The only other Federalist, besides Robert Morris and 
Gouverneur Morris, that deserves any credit, was Huger of South Carolina, to whose utterance I have already referred. At this stage Huger made an agreement with his colleagues from South Carolina, that they would all withdraw, and permit the delegation to vote a blank; but it must be remembered, that even if Huger's colleagues had not agreed to that, Morris's withdrawal, leaving Lyon to cast the Vermont vote for Jefferson, settled the election.

Meanwhile, the rank and file of the Federalists had not sympathized, as a body, with this action of their leaders. Some of them felt humiliated; some angry; many of them went over bodily to the Republican party, and Jefferson properly said: "This conduct of the minority has done in one week what very probably could hardly have been effected by years of mild and impartial administration."

The full measure of the success. which Jefferson had wrought can be appreciated, when one contemplates this contemptible scene in which the reactionary leaders had acted their respective roles, and then remembers, that there has never been another day to dawn in America, when any lot of politicians anywhere - however talented, rich or respectable would have dared to attempt to reënact it. No party will ever attempt again to set aside the undisputed result of an honest election by the people. Such an $\mathrm{X}$-ray did this pitiable spectacle shed upon the nature and tendencies of the counter-revolution, that twothirds of both Houses and three-fourths of the States, as soon as the machinery provided by the Constitution 
could move, enacted an amendment to the Constitution, that it might never be repeated.

This amendment constitutes one of the permanent gains for American institutions, which may properly be credited to Jefferson's cool and unwavering constancy, and to the inspiration it gave to that superb, unbroken and unbreakable phalanx of his followers in the House, who asserted the elementary doctrine: "Let the will of the people, honestly and constitutionally expressed, be done." This elementary creed of republics, no single Federalist leader - except one Morris at the last, and another Morris and Huger, from the beginning - seemed so much as to scent.

Bayard, of Delaware, who may be said to be the man, who historically sang the Federalist swan song, in a letter to Alexander Hamilton, dated March 8, 1801, which may be found in Hamilton's "Works," Volume 6, page 524, says: "The means existed of electing Burr, but this required his coöperation. By deceiving one man, a great blockhead, and by tempting two, not incorruptible, he might have secured a majority of the States." Bayard adds an expression of his indignation and disgust in these words: "He [Burr] will never have another chance of being President of the United States; and the little use, which he has made of the one which has occurred, gives me but an humble opinion of the talents of an unprincipled man." Nothing better shows the spirit of the anti-Democracy. That Burr was an unprincipled man, there can be no doubt, but if it be true that he refused to "deceive one man" and to corrupt two others, then there stands in history at least something to his credit! Now, there was no man 
of higher character, more respectable talent, greater personal probity in private life than James Bayard of Delaware; yet he uttered the words quoted. They were the natural outcropping of a political system, the keystones of whose structure were contempt for the "common herd," and the divine right of the selfassumed "better element" to rule. For this world has been plagued not only with the doctrine of the "divine right of kings," but with this lesser, and later, doctrine, based upon a still more insidious assumption. A little thing like deceiving a blockhead and buying two corrupt politicians ought not to stand in the way of the rule of the wise and good! If given the creed, the conduct follows.

Professor Tucker, in his "Life of Jefferson," to show how far this awful doctrine could carry its wicked influence, says: "General Lee, of Virginia, it was said, was earnest in advising this desperate measure" (that is, putting the Secretary of State in as President). This Lee was "Light Horse Harry" of "the Legion," a brave soldier and a gentleman, with generations of gentlemen's blood in his veins! Gouverneur Morris, in a contemporaneous letter, says: "Desperate measures were contemplated," and describes what the desperate measures were - substantially what Bayard said they were.

Jefferson owed no debt of gratitude to the Federalist leaders, and the war between him and them must go on; but he felt quite differently towards the rank and file of that party - the misled, and not the misleaders. They had never been consciously and premeditatedly monocratic. From the very first hour 
of his administration the administration was fair and even generous to them, and every possible means of reconciling them to republican rule was used. This spirit was fully disclosed in his inaugural address.

This inaugural address has had a permanent and abiding influence upon the political thought and the spirit of the institutions of the American people. It has been from the day it was spoken down to now a "Sermon on the Mount," not alone for those who call themselves Democratic, with a big "D," but for all men with democratic hearts and purposes. He emphasizes as "the vital principle of republics, from which there is no appeal save to force" - the vital principle of despotisms - "an absolute acquiescence in the decisions of the majority honestly expressed." $\mathrm{He}$ does not once mention the House of Representatives, nor, except in this indirect way, criticize it. If the reader has not read this address, I request him to read it at once; if he has read it, let him read it over again.

However hypocritical the pretense upon the lips of politicians may often be, no man has, since 1808, hoped to be taken as thoroughly American, unless he professed faith, in the long run, in the common sense of the people, and their "essential rectitude of purpose," a faith which was expressed by Lincoln later in the phrase, "You can fool some of the people all the time and all of the people some of the time, but you cannot fool all the people all the time;" a faith, which was much better expressed by Jefferson in the words, "Error is not to be feared, if reason be left free to combat it."

But even with the result, the counter-revolutionary scheming did not cease. In answer to a letter in which 
Hamilton had raised the question of the Republican repeal of the Federal judiciary act - through whose new and numerous judges the Federalists had hoped still to unshape our institutions - Bayard warned him that he, Bayard, had "had an opportunity of learning the opinions of the Chief Justice," and that the latter "considered the late repealing act as operative in depriving the judges of all power derived under the act repealed." By the way, this sheds a side-light on some things. Here was Bayard, practically the Senate leader of the Federalists, getting an "off-the-bench" opinion from John Marshall, Chief Justice of the United States, in advance of the presentation of a case before the court, and while the public generally would remain in ignorance of the position, which the court would take. I remember the fine indignation of a gentleman, whom I once knew, the judge of a Mississippi circuit court, when a lawyer came to him off the bench to get his opinion concerning the unadjudicated constitutionality of a State statute.

Hamilton's outline of a so-called "Christian Constitutional Society," though it "died aborning" under Bayard's discouragement, and probably the discouragement of others - practical men - was the last desperate dying struggle on the part of the American CounterRevolution. With it ends the last readable page of this "Suppressed Chapter of our History." Read it; it is worth reading. It is such a curious anachronism to have been written in America, for Americans.

While apparently intending to criticize Jefferson, Curtis, in the following words, pays him the highest possible tribute:- 
"Jefferson intended that the new nation should be a democracy, and he would rather have let the whole world perish than that this purpose should fail. Nevertheless, he was the most absolute monarch that ever sat in the Presidential chair. Although he introduced the practice of discussing all matters in his Cabinet and deciding the questions of importance by vote, his powerful individuality and persuasive reasoning controlled his advisers in that official family, and in Congress. He exercised an influence in both Houses of the National Legislature and with the people that has never been equalled by any of his predecessors. He formed a powerful party, he directed its action, and he selected its principles, but he never assumed the attitude of a 'boss."

In connection with this statement that "Jefferson led his party," as thoroughly as "an absolute monarch," it may well be remarked that America has never suffered from too much political leadership. We have not had enough of it. True, we have had too much unofficial, unelected, irresponsible leadership, or too many "bosses." But a man selected to lead and leading by convincing others that he is right, by appeals to the popular heart and head, has no followers except volunteers, and, they even, not "for the war," but only during his "good behavior." The reason why a genuine democracy, oftener than a party not founded on its principles, follows a leader, is because it is only the head of a party with that faith, that dares or can appeal frankly to the common-sense and common-conscience of the masses. How can a multitude follow him, who does not trust them, nor, at heart, recognize their reason and rectitude of purpose, and not recognizing them, can therefore not sympathetically appeal to them? 


\section{CHAPTER VI}

\section{THE INFLUENCE OF JEFFERSON AS PRESIDENT}

\section{1. "MY PASSION IS PEACE"}

Throughout Jefferson's whole administration, the chief thing in his view was the democratization of the Federal Government. For this, a frugal, simple government, and peace, were absolutely necessary. This accounts to a large extent for his peace-at-almostany-price policy.

In a letter to Noah Worcester (Massachusetts collection), he says:-

"Of my disposition to maintain peace until its condition shall be less tolerable than war itself, the world has had proofs, and more, perhaps, than it has approved;. . . if by the inculcations of reason or religion, the perversities of our nature can be so far corrected, as sometimes to prevent the necessity, real or supposed, of an appeal to the blinder scourge of war, devastation and murder, the benevolent endeavor of friends of peace will not be entirely unremunerated."

If deeds, or lack of deeds, flowing from such a creed be error, it is humanizing error, requiring more resolution and courage, than it required a hundred years after the time, for a citizen of a compact, wealthy and strong country, of nearly one hundred millions of inhabitants, unassailable by any foreign influence to call it "infamous conduct."

If infamous, Washington's administration was "in- 
famous" for the same reason. and that of Adams only a little less so.

Washington submitted to the humiliation of recommending and signing the Jay Treaty. It required courage to do it.

If our early history, while the government was a-forming, had been either one of war and victory and conquest, or one of war and defeat and desolation and debt, a beginner can spell out for us a fate totally different from that which we have enjoyed.

Washington and Jefferson were great, but greater in nothing than in not permitting "the Maniacal War Fury of Europe" to spread its contagion to America. Washington, perhaps, deserves the more credit of the two, because he first set the pace. However that may be, there is "glory enough to go round," as Schley said, and Washington's preëminence consists in this, that without his great name, neither Jefferson as his Secretary of State, nor any other man, amidst all the then provocations to popular passion, could have started us off right, as "The Great Peace Nation of the Earth."

Few have better expressed our special reasons and our peculiar opportunity to set an example of peace to all the world, than Jefferson:-

"Separated by a wide ocean from the nations of Europe, and from the political interests, which entangle them together, with productions and wants which render our commerce and friendship useful to them and theirs to us, it cannot be the interest of any to assail us, nor ours to disturb them. We should be most unwise, indeed, were we to cast away the singular blessings of the position in which nature has placed us, the opportunity she has endowed us with of pursuing, at a distance from foreign contentions, the 


\section{PERMANENT INFLUENCE OF JEFFERSON}

paths of industry, peace and happiness; of cultivating general friendship, and of bringing collisions of interest to the umpirage of reason rather than of force."

I like those last words, which I have italicized.

In one of his messages these words - so much too wise for Jingoes to comprehend - occur:-

"Our duty, therefore, is to act upon things as they are, and to make a reasonable provision for whatever they may be. Were armies to be raised whenever a speck of war is visible in our horizon, we should never have been without them. Our resources would have been exhausted on dangers, which would never have happened, instead of being reserved for what is really to take place."

It is popular to talk about our being "an unready nation," and about how much is added to the cost of war in life and treasure by the fact that we are never prepared for it; but those who talk thus forget the other side of the shield. If we are to be kept always prepared for war, then we are never prepared for the utmost possibilities of peace, and it is far better to strain our backs to an extra burden, now and then, when war is unavoidable, than it is to keep them burdened all the time. Every dollar which goes into war preparation goes out of peace progress; it is subtracted from public roads, popular education, internal improvements, good churches, clothes or food for the people subtracted somewhere from industry or improvement. The real truth is, the constant drain pre-decreases our strength either for offensive or defensive war when it comes.

Besides; being "always ready" is an ever-present temptation to make war wantonly. A nation thus 
"fixed" is like a man with a pistol - he wants to use it, to see if it is not rusty.

Jefferson in one of his letters, says: "I frankly confess that my passion is peace." And in another place he voices this utterance, by way of a sublime paraphrase: "Let all the world pray to Heaven that at length there may be on earth peace and good will toward men."

In connection with the designation by Mr. Theodore Roosevelt of the conduct of Jefferson and Madison in "not preparing for war," as "infamous conduct," Mr. Tom E. Watson is very happy. What he says is worth reading from every standpoint, and can be found on pages 445 and 446 of his "Life of Jefferson."

Anent the Leopard-Chesapeake incident, Jefferson wrote: -

"I had only to open my hands and let havoc loose. . . . If ever I was gratified with the possession of power and of the confidence of those who intrusted me with it, it was on that occasion, when I was enabled to use both for the prevention of war, toward which the torrent of passion was directed almost irresistibly, and when not another person in the United States, less supported by authority and popular favor, could have resisted it."

I think the best judgment will be that the early Presidents acted wisely in their "Peace-at-almost-anyPrice" policy, in their avoidance of war till, like Topsy, we were "growed up" a little. It would not be many years before instead of accepting terms from others, we could impose them. So convinced was Jefferson of this that he was wary of all such treaties and agreements as were practically to be hoped for in his day.

This sound reasoning and sentiment occur in a letter 
to his son-in-law, Jack Eppes, dated September 27, 1811:-

"I am so far, in that case, from believing that our reputation will be tarnished by our not having mixed in the mad contests of the rest of the world, that, setting aside the ravings of pepper-pot politicians, of whom there are enough in every age and country, I believe it will place us high in the scale of wisdom to have preserved our country tranquil and prosperous during a contest which prostrated the honor, power, independence, laws, and property of every country on the other side of the Atlantic. Which of them have better preserved their honor? Has Spain, has Portugal, Italy, Switzerland, Holland, Prussia, Austria, the other German powers, Sweden, Denmark, or even Russia? And would we accept the infamy of France or England in exchange for our honest reputation, or the result of their enormities - despotism to the one, and bankruptcy and prostration to the other - in exchange for the prosperity, the freedom, and independence which we have preserved safely through the wreck?"

There was ever present for Jefferson, and there is ever present for the true Jeffersonian since, a broad vision of world democracy and world peace.

Henry Adams splendidly says:-

"Jefferson aspired beyond the ambition of a nationality and embraced in his view the whole future of man. . . . He wished to begin a new era. Hoping for a time when the world's ruling interest would cease to be local and should become universal ... . he set himself to the task of governing with this golden age in view. Few men have dared to legislate, as though eternal peace were at hand, in a world torn by wars and convulsions and drowned in blood; but this was what Jefferson aspired to do. . . . As he conceived a true American policy; war was a blunder, an unnecessary risk; and even in case of robbery and aggression the United States, he believed, had only to stand on the defensive in order to obtain justice in the end. He would not consent to build up a new nationality merely to create more armies and navies, to perpetuate the crimes 
and follies of Europe. The central Government at Washington should not be permitted to indulge in the miserable ambitions, that had made the Old World a hell, and frustrated the hopes of humanity."

Shall we permit what Jefferson would not? Is the spirit of peace to continue permanently, as the indwelling soul of our body politic?

\section{2. "AN EMPIRE FOR LIBERTY"}

Jefferson, the republican expansionist, had been all his life looking across the Blue Ridge from the plantation porch towards the Western country. During the Revolutionary war he realized the value of having possession of it. A Treaty of Peace would be based upon the principle of uti possidetis, and it was for this reason that George Rogers Clark, whom John Randolph of Roanoke subsequently called, in his high-flown style, the "Hannibal of the West," was sent to take possession of the northwestern country. Sufficient attention has never been paid by historians to the effect of the success of this movement upon the subsequent extent of our national domain.

When Jefferson was Secretary of State in 1790, it looked at one time as if Great Britain were about to seize New Orleans. Jefferson advised President Washington then, that the United States ought to go to war to prevent it. In the same year he gave a warning to France upon the same subject through the American Minister at Paris, saying that such an act would be regarded as unfriendly to the United States, and, in the long run, "not beneficial to France." Remember this was as early as 1790 . 
Let us take up the story of Louisiana.

The information came to America of the cession of Louisiana and the Floridas by Spain to France. In so far as the Floridas were concerned it was error, but if the reader will keep in his mind the fact that the news came that way it will unravel some tangles. At once, Mr. Jefferson wrote to Mr. Livingston, our Minister at Paris, a letter dated April 18, 1802, which was strong and uncompromising.

In connection with the effort that has been made in some quarters to give an over-share of the credit of the purchase of Louisiana to Livingston, Mr. Morse is, at any rate, not deluded. He says in his "Life of Jefferson": -

"Jefferson put on foot the movement for the purchase of Louisiana. ... But that minister [meaning Livingston], before he had learned the executive purpose, had unfortunately expressed very different views of his own. He had told the French government that the United States cared not at all whether their neighbor at the mouth of the Mississippi was to be France or Spain, provided the right of navigation and privileges of deposit should not be interfered with. After correction, indeed, he began to discuss a purchase, and in time would probably have concluded it; but Jefferson, for many reasons, chose to send a special emissary."

Even later Livingston wrote to Madison these words:-

"I would rather have confined our views to smaller objects, and I think that if we succeed, it would be good policy to exchange the west bank [of the Mississippi] with Spain for the Floridas, reserving New Orleans."

To this proposition Jefferson expressed his opposition, shrewdly believing that we would obtain Florida any- 
how, when the fruit was ripe; that is, whenever Spain involved in war would want or need to sell; and that the thing of chief value to us was the free and exclusive navigation of the Mississippi, which could not well consist with the possession by any power of territories upon its western bank, or even upon its western tributaries.

As late as the afternoon of April 11, 1803, Talleyrand astounded Livingston with these words: "Does the United States wish the whole of Louisiana?" Livingston replied: "No; we only want New Orleans and the Floridas." That evening Monroe arrived in Paris. He came with verbal instructions from the President, and the pathway for American negotiators was simplified.

\section{Jefferson had said: -}

"The day that France takes possession of New Orleans fixes the sentence which is to restrain her forever within her low water mark. It seals the union of two nations, who in conjunction can maintain exclusive possession of the ocean. From that moment we must marry ourselves to the British fleet and nation. . . . The first cannon, which shall be fired in Europe, [will be] the signal for tearing up any settlement she may have made, and for holding the two continents of America in sequestration for the common purposes of the united British and American nations."

Professor Hart in his "Making the American Nation," says:-

"Never in all his long and varied career did Jefferson's fox-like discretion stand him in better stead. Instead of following the public clamor, he calmly formulated a policy and carried it through to a most successful termination.

"The first thing to do was to quiet the public mind; the second was to regain the right of deposit; the third was to steer a tortuous 


\section{PERMANENT INFLUENCE OF JEFFERSON}

course between France and England and to take advantage of every possible opening to secure possession of New Orleans and the Gulf coast, and in this way to put an end forever to all chances of similar trouble in the future."

If it had been anybody but Jefferson the adjective above would have been "wise," not "tortuous."

In the preface of a little book entitled "The Louisiana Purchase," by Winship and Wallace, I find this language:

"Little did either France or the United States dream, on that eventful last day of April, 1803, of all that lay in the sale by the one and the purchase by the other of the vast and unknown territory called Louisiana."

If by that is meant that not many people in France, or in the United States dreamt all that it meant for the future, the statement is, of course, a truism. That is true, at the time of its happening, of almost any great transaction; but if it is meant that the men possessing the great guiding minds on both sides, Jefferson and Napoleon, did not fully realize why they did what they did, and what it all meant then and for the future, it is a great mistake.

Napoleon knew that he had made up his mind to go to war with England again; that, if he did, the chances of his being able to retain Louisiana were one in ten; that even if the United States did not stir a foot, Great Britain, if earnestly intent upon it, could capture New Orleans and hold it, and that holding New Orleans and the mouths of the river, she would control the interior, at least as against France. But he knew more than that, for Jefferson had told him so, that the United States, in the event of his keeping Louisiana, must 
"marry themselves," to use Mr. Jefferson's language in the negotiations, "to the British fleet and nation." $\mathrm{He}$ knew that Jefferson was only waiting, until the war broke out, for the co-operation of a British fleet, to turn loose the land-hungry and warlike frontiersmen of Kentucky, Tennessee, and the Mississippi Territory to seize the French possessions all the way down the river, including New Orleans.

That Jefferson fully understood the importance of the entire matter is indicated by his language:-

"Every eye in the United States is now fixed on the affairs of Louisiana. Perhaps nothing since the Revolutionary War has produced more uneasy sensations through the body of the nation."

\section{And this:-}

"The cession of Louisiana and the Floridas by Spain to France works most sorely on the United States. . . . It completely reverses all the political relations of the United States, and will form a new epoch in our political course. . . . There is on the globe one single spot, the possessor of which is our natural and habitual enemy. It is New Orleans, through which the produce of three-eighths of our territory must pass to market, which from its fertility will ere long yield more than half of our whole produce, and contain more than half of our inhabitants.

"France, placing herself in that door, assumes to us the attitude of defiance. Spain might have retained it quietly for years. Her pacific dispositions, her feeble state, would induce her to increase our facilities there, so that her possession of the place would be hardly felt by us. And it would not be very long, perhaps, when some circumstance might arise which might make the cession of it to us the price of something of more worth to her.

"Not so can it ever be in the hands of France; the impetuosity of her temper, the energy and restlessness of her character, placed in a point of eternal friction with us, and our character, which is as high-minded, enterprising and energetic as that of any nation on 
earth, ... render it impossible that France and the United States can long continue friends, when they meet in so irritable a position. They, as well as we, must be blind if they do not see this; and we must be very improvident if we do not begin to make arrangements on that hypothesis."

As far as this particular great transaction was concerned, there were simply two parties to it: one, Napoleon the Great, and the other, Jefferson, the Seer - the see-er.

When the treaty was signed Napoleon said: "A few lines of a treaty restored to me the Province of Louisiana and repaired the fault of the French negotiator, who abandoned it in 1763. But scarce have I recovered it when I must lose it again." (Italics are always mine.)

It was a case of "must," and Napoleon knew it. He realized fully what he was parting with. He also saw that, by its cession, he not only prevented a present alliance between these two English-speaking countries, but that he dealt a blow, which would, in the long run, possibly count very much against his arch enemy, England.

The only reason why his prophecy about "our humbling Britain's pride on the ocean" has not come to pass is that we have grown to be such a stupendous people in resources and reserved power, that nobody wishes to challenge us to a contest. If there were the slightest need, we would be in command of the seas.

Jefferson began to buy Louisiana without consulting Congress. Well does Mr. Bryce, in his "American Commonwealth," say: "This was the boldest step that a President of the United States has ever yet taken." The committee report, which recommended the legislation appropriating $\$ 2,000,000$ declared that it was 
"to enable the executive to commence with more effect a negotiation with the French and Spanish Governments relative to the purchase from them of the Island of Orleans and of East and West Florida." Remember that it was at that time thought in America that New Orleans and East and West Florida were the lands ceded by Spain to France.

Upon the question how far Jefferson had in contemplation the possibility of securing all of the Louisiana territory, there have been many words written. The truth seems to be that the minimum of his desire, without which an English alliance and war must be our recourse, was the city and island of Orleans, to which he would have preferred these plus East and West Florida, but that he would have preferred above all else the purchase of everything, which Spain had ceded to France, of the exact extent of which he was then ignorant. Further, to sum it up, it appears that Monroe was sent with only verbal instructions to join Livingston, expressly in order that the American negotiators might be prepared for any contingency, which might present itself.

Few men were quicker to take a hint of any description than Napoleon the Great. No man ever lived who saw the end of a military, or naval, situation in advance, as completely as he. A man with a very much smaller military insight could have foreseen that while England remained the mistress of the seas, and the United States of America remained the mistress of their own land and, except for England, of their local waters, it would be impossible for him to land a single soldier at 
the mouth of the Mississippi river, or, if landed, afterwards to withdraw him.

It has been frequently said that Napoleon "by one of his sudden impulses, changed his whole policy," and concluded to sell Louisiana. Lucien Bonaparte, in his half-serious, half-humorous, description of the conversation, which he and Joseph had with Napoleon, while the latter was in the bath tub, has spread this notion over the world.

Napoleon never acted by "sudden impulses." $\mathrm{He}$ sometimes pretended to do it. You may depend upon it that he traveled in thought all over this Louisiana question and found himself in a cul de sac, with no way out, except either the surrender of Louisiana in war, or its sale in peace. The only way he could have kept Louisiana was to have kept the peace. This he either could not do, or desired not to do. Hence, the moment he made up his mind to renew war with England, he wanted to sell Louisiana before he declared war and before his enemy could declare it. He even antedated the treaty. If he could sell it and get the money in his pocket, then he could leave England to do what she pleased - either acquiesce, or take on a new enemy.

No great judge, or lawyer, nor any of Jefferson's friends, agreed with him in his doubt of the Constitutional right to acquire territory by treaty. Indeed, the sole contention even of the Federalists, in their subsequent effort to embarrass the administration was that Congress had no power to acquire territory "to be formed into States of the Union."

The threats of dissolution of the Union made by the New Englanders were not based so much upon the 
ground of the acquisition of the territory, as on the declared intention of carving it up into States to be admitted to the Union, as a part of the governing power of the United States. The third article of the treaty of cession contained this language:-

"The inhabitants of the ceded territory shall be incorporated into the union of the United States and admitted, as soon as possible, according to the principles of the Federal Constitution, to the enjoyment of all the rights, advantages and immunities of citizens of the United States."

It was when that part of the Louisiana Territory, which we now call the State of Louisiana, knocked at the doors of Congress for admission as a State and nine years after the purchase, that Josiah Quincy made that noted speech, in which he said:-

"I am compelled to declare it as my deliberate opinion, that if this bill passes, the bonds of this Union are virtually dissolved; that the states, which compose it, are free from their moral obligations; and that as it will be the right of all, so it will be the duty of some to prepare definitely for a separation; amicably, if they can; violently, if they must."

It is rather curious, and a good deal of an impeachment of Mr. Jefferson's usual clearness of thought, that he should have permitted the character of our Government with regard to domestic affairs and its character with regard to foreign affairs to become mixed in his mind. The States delegated to the general Government all the power they ever possessed with regard to foreign affairs, consequently reserved none. All "the powers not delegated" to the Federal Government " are reserved to the States, and to the people," but with regard to our relationship to foreign governments all power 
having been delegated and, hence, none reserved, the Federal Government has every power, except such as may be expressly prohibited to it by the Constitution, or, ex necessitate rei, forbidden by our dual system of government. In other words, the Federal Government cannot, under the pretext of international relations, legislate by treaty upon State domestic affairs. For example, it can not by treaty dictate to the people of California the character, or management, of their public school system - not because the Federal Government has not every power with regard to international and foreign affairs, but because this is not an international, nor a foreign affair.

Gallatin, Madison and all Jefferson's friends took the position that, with regard to foreign relations, the States were preëminently one; that the power of acquiring territory as a result of war, or as a means of settling international disputes had to reside somewhere; that as the States had delegated all power with regard to international relations, it must reside in the Federal Government; that, in conferring the treaty-making power, the fact that it had been conferred without any limitation prohibiting the acquisition of territory, was itself eloquent in behalf of their contention; that, although the treaty-making power could not amend, nor alter the Constitution of the United States, nor change our dual system of State and Federal Governments, nor deprive any citizen of his protection under the constitutional bill of rights, nor do any other thing forbidden by the Constitution, it was yet unlimited, in the sense, that anything, not prohibited to the whole Federal Government, nor expressly and exclusively 
vested in some other branch of it, could be done by it under the treaty-making power. Not only had the States expressly delegated all the treaty-making power to the Federal Government, but that there might be no doubt about the fact that it was a complete and exclusive delegation of a full power, without residuum, they, in another clause of the Constitution, expressly prohibited to themselves all power to enter into leagues, or treaties.

The position, however, which was taken by Madison, Gallatin and others, is totally different from that taken by a later administration with regard to the Philippines and Porto Rico. It was never contemplated by any of the men of that party, which added two-thirds of our domain to the Union, that any part of it, after acquisition, could be indefinitely governed in absolutism, as conquered territory. True, it was contended, that in "a period of transition" between the moment of the "cession" and the moment of the "incorporation, according to the principles of our Constitution," the territory must be governed by Congress; and that in the interval between the cession and the date at which even a territorial government could be set on its feet, some government, de facto, must exist.

This mistake of Mr. Jefferson's is all the more peculiar because it stands in its class alone. In every other respect, he seems to have appreciated fully, that, with regard to foreign affairs, the United States Government had plenary power, except in so far as Constitutional prohibitions and the very nature of our dual government constituted a limitation. In one sense, of course, no government, under the American theory, has absolutely 
plenary power, not even a State government - even over matters of internal police. All American governments are limited by express prohibitions in State or Federal Constitutions. The Federal Government in regard to foreign relations is thus limited; but not by the operation of the reservation clause. The limitations on it, with regard to foreign affairs, are like the limitation upon State governments, with regard to domestic affairs. Mr. Jefferson himself, in another place, said, that the powers of the Federal Government were divided into two classes, foreign and domestic, and used this language: "The States are independent as to everything within themselves, and united as to everything respecting foreign nations." Long prior to that, he had written from Paris, when we were about to form the new Constitution, that this was the principle upon which it should be framed.

The recent Porto Rican and Philippine cases are not to be reconciled either with previous decisions, with one another, or with themselves. The De Lima case partially announces the old and theretofore accepted doctrine; the Downes case crawls out from under it.

The Supreme Court, in the case of Cross vs. Harrison decided that, after the ratification of the treaty of Guadaloupe Hidalgo, California became a part of the United States, and a bare majority of the Court recently in the Downes case decided that, after the ratification of another treaty, Porto Rico did not become a part of the United States! The Court in the former case said that California "became instantly bound and privileged by the laws which Congress had passed to raise a revenue from imports and tonnage" 
Justice Brown in the latter case declared that neither the Constitution nor the revenue laws extended over the island ex proprio vigore, and not until Congress said so; in other words, that the Constitution of the United States - the fundamental voice of the people - prescribed and announced to control all functionaries created by it and subject to change only in the way designated in the body of it - is an overcoat, to be put on, or removed, by Congress to suit the weather at Washington.

The idea in the Chief Justice's mind seems to be, that the old overcoat is not big enough, or otherwise does not fit, and that if the attempt is made to cover with it not only "contiguous territory," but "distant possessions," there is great danger of splitting it! Quite true, too.

I am old-fashioned enough, however, or, as I would rather express it, have laic common sense enough, to believe that, if it is found that we cannot govern certain "distant possessions," with "alien populations" in accordance with the Constitution of the United States (subject to which every possible functionary of the Federal Government everywhere must act), that one of three things ought to follow: either - warned by the fact - we ought not to annex them, or, having annexed them, we ought, under just and safe provision, to let them go, or else an amendment to the Constitution giving the powers necessary, in the cases designated, should be asked. Queer idea this. that "the court should make concessions!"

Justice Harlan, in his dissenting opinion, rises to the height of eloquent statesmanship. He announces that every branch of the Federal Government is "tethered 


\section{PERMANENT INFLUENCE OF JEFFERSON}

by the Constitution," and that this is a government, which has no power, either at home or abroad, in the Territories, or in the States, or in "appurtenances" or "appendages," or anywhere else, "except such power as is derived from the Constitution," and that "international law has not been so incorporated into our institutions," as that "an agreement with a foreign nation can change, alter, or amend the Constitution."

I haven't time to go into all this, but I wish the student would read the second chapter of Sidney Webster's little book, "The Two Treaties of Paris," where the whole thing is set forth in its miraculous incomprehensibility, and its full enormity.

Upon this question it is well to quote in this connection an excerpt from a letter written by Gouverneur Morris on December 4, 1803. It will be remembered that he was the chairman of the Committee on Style in the Constitutional Convention, and, therefore, the formal draftsman of the Constitution:-

"I always thought that when we should acquire Canada and Louisiana, it would be proper to govern them as provinces and allow them no voice in our councils. In wording the third section of the fourth article I went as far as circumstances would permit me to establish the exclusion. Candor obliges me to add my belief, that, had it been more pointedly expressed, a strong opposition would have been made."

This note shows that in Morris's opinion there was no doubt of the contemplation by the framers of the Constitution, at the very time of its adoption, of possible acquisition of foreign territory; Canada and even Louisiana, being in remote contemplation. It shows, moreover, that he himself, although in favor of govern- 
ing such territory merely "as provinces," was afraid to let this latter idea be known to the Constitutional Convention. In fact, under the Continental Congress, previous to the time of the adoption of the present Constitution, and at the time of its adoption, the American people had in view the possibility that at some time the British American Provinces might want to be admitted into the Union. The hope has only recently disappeared since the British Canadian Provinces have developed into a great, prosperous, free and selfgoverning dominion, and have become perfectly reconciled, under their substantial autonomy, to the nominal rule of the mother country.

Professor Hart says that, "Diplomatically, Jefferson, Livingston and Madison had achieved nothing; Louisiana had been thrown into their hands through no efforts of theirs." This is not a just thing to have written. It is true, they first thought all we could get was the city and so-called island at the mouth of the Mississippi, and, perhaps, West Florida, and began negotiating for that. But, if we could have purchased nothing but the Island of Orleans, including the City of New Orleans, still the upper part of the Louisiana Territory must necessarily have fallen into our hands. The French would have had no way of getting to it, or defending it, from the south except by our permission, or from the north except by England's permission. Talleyrand was right, when he said to Livingston that "without New Orleans, Louisiana itself would be of no use to France."

By the acquisition of Louisiana, these great aims were attained: The exclusive navigation of the Mississippi, 
making it the great commercial artery of the country and an unshackled outlet for our produce; a vast territory, fitted by soil and climate for home-making for the sons and daughters of the Republic, became their heritage; potentially, and, in fact, almost immediately there accrued a large increase of the annual revenues; it effected the removal of possible enemies from immediate contiguity, minimizing the occasions for wars; it gave a guarantee of an extension of field for the development of American institutions, individual freedom, and democratic laws. As Jefferson expressed it, it gave us "a new empire for liberty," which, "with our old," constituted such a domain, "as she had never witnessed."

Senator Hoar said he never thought of Jefferson without seeing him "with the Declaration of Independence in one hand and the Louisiana treaty in the other."

Curtis says: "It seems inexplicable that Jefferson did not include in his epitaph his acquisition of the Louisiana Territory." In this he shows a complete lack of comprehension of the character of the man. Nothing in the way of mere material acquisition was to a mind like Jefferson's a primary, or an eternal thing. To such a mind, acquisition of territory might be a means and very valuable, but not an end. Men are not made free, or happy, because of the area of the country in which they live. Territorial acquisition is a secondary and not a primary thing in the political philosophy of a man like Jefferson - good only, if it extend "an empire for liberty." The acquisition of Louisiana was not "the greatest benefit that Jefferson ever conferred upon his country." The Jeffersonian 
spirit was. This Jeffersonian spirit was permanently embodied in our institutions, simultaneously with the defeat of the Counter-Revolution.)/

Curtis declares that Jefferson was not the originator of the project of acquiring Louisiana, and says that as far back as the Revolution, the necessity of controlling the mouth of the Mississippi and its navigation had become apparent to many minds. In the same way, he might deprive Lincoln of the credit of emancipation, because as far back as the Revolution, and, indeed, prior to it, the idea that the temple of democracy would be more symmetrical and more enduring, if slavery were abolished, had "been apparent" to very many other minds also, to Jefferson's among others. Christopher Columbus was not the first man to dream of lands to the West, but he was the first man who "got there."

The expansion advocated and effected by Jefferson and that advocated and effected by McKinley and the negotiators of the second Treaty of Paris cannot be compared. They must, in all respects, be contrasted.

Jefferson annexed to the American domain vast areas of unpeopled lands, contiguous to American territory, the possession of which was essential to American defence, and which were fit for home-making by the sons and daughters of the American Republic.

McKinley annexed distant possessions, densely populated, destined at no time to become parts of the governing American people, and incapable of becoming so, without poisoning our body-politic by the infiltration of alien and unassimilable blood, and requiring an increased naval and military force to hold them. 
In the treaty bringing to us the Louisiana Territory, the United States stipulated that the inhabitants should be governed "according to the principles of our Constitution," and should, "as soon as possible," consistently with those principles, "be incorporated into the Union." Although the inhabitants of the ceded territory did not become immediately a part of the governing United States, they knew and were assured from the beginning that such was their destiny, and they secured in advance, as soon as territorial government could be organized, the full individual protection of every article of the Federal Constitution.

On the contrary, the second Treaty of Paris, which brought to us the Philippines, contained the language that "the civil rights and political status of the native inhabitants of the territory hereby ceded to the United States should be determined by Congress." Instead therefore of the inhabitants obtaining the nationality of citizens of the United States, they obtained that of Porto Ricans and Filipinos.

When Congress passed its first act for the government of Louisiana, it is true that it vested in persons to be appointed by the President all powers of government, but it was with this ever-memorable limitation upon the character of those powers and the exercise of them; that they were to be exercised "for maintaining and protecting the inhabitants of Louisiana in the free enjoyment of their liberty, property and religion."

Sidney Webster, in his "Two Treaties of Paris and The Supreme Court," says:-

"Congress thereby enacted, in effect, that the former Spanish and French laws - excepting always, and of course, those for- 
bidden by our Constitution - should be the laws of the new acquisition till Congress make others. Jefferson was commanded to supervise the execution of the enactment."

Under the new dispensation, the Spooner Amendment of March, 1901, is very much broader. The language of it is: "All military, civil and judicial powers, necessary to govern the Philippines, shall be vested in such person and persons, to be appointed by the President, and to be exercised in such manner as the President shall direct." "It contains no limitations at all upon the governing powers of the President's appointees, except his direction," and no limitation upon him, except that the "powers" shall "be necessary to govern the Philippines." The language of the enactment in Jefferson's time might have been repeated. It was purposely not repeated.

The cardinal difference is that the Spooner Amendment did not recognize (in fact, those who voted for it denied), that the inhabitants of the Philippines, or of Porto Rico, received, by the fact of their coming under the American flag and becoming subject to American sovereignty, any Constitutional protection whatsoever. Indeed the advocates of the McKinley species of "dependency" and "appurtenancy" government were much disturbed by the opinion long before given by John Marshall in the case of Loughborough vs. Blake, to the effect that the phrase "throughout the United States," "designated our great republic, composed of States and Territories." The course pursued by the United States, with regard to the Louisiana Territory, under the treaty with France, and that with regard to the Florida Territory, under the treaty with Spain in 
1819, and that with regard to the territory acquired from Mexico, as a result of the treaty of Guadalupe Hidalgo, were essentially the same, although the language of the treaties differed somewhat. But in every instance the intent and purpose and promise - the only purpose consistent with American institutional and constitutional ideas - was preserved, to wit: That the people of the acquired territory should not be indefinitely governed in absolutism without their own consent, but should at some time become a part of the governing United States.

Pitt the elder - Earl of Chatham - the "Empire Builder," in a speech in Parliament, once said:-

"From all the history of the European world since the later days of the Roman Republic, there is no more important lesson to be learned than this, - that it is impossible for a free people to govern a dependent people despotically, without endangering its own freedom."

I have always been endeared to this utterance and it has been the guiding star of my own walk from the moment that the United States undertook to "go a'worldpowering" with purposes of "benevolent assimilation" in the Philippine Archipelago for a pretext.

It was in January, 1802, that Jefferson sent his message to Congress proposing the exploration of the Western country to the Pacific Ocean. This resulted in the Clark and Lewis exploration, which gave us our firmest basis for claim of title to the Oregon country. It will be noted that this was before the cession of Louisiana and not afterwards. Nor was the exploration to be confined to the Louisiana territory. As a matter of fact, it went far beyond it, to the Pacific Ocean. 
Thus Thomas Jefferson not only gave us Louisiana by purchase, but gave us the claim, by exploration and discovery, to the Oregon country, which carried our boundary to the Pacific and made us truly Continental.

Jefferson's vision was broad. He saw, as no other man of his time saw, the importance of adding to the territory of the United States contiguous lands fit for homes for the sons and daughters of the people and for European immigrants. He saw its importance as a safety valve socially and politically, for us and for the white race in Europe, and its importance as a part of his great Peace Policy. It is not strange, therefore, that the annexation of Louisiana was not the limit of his endeavor, but that during his entire administration he was engaged in attempting to secure the Floridas by negotiation and purchase. Had it not been for John Randolph's venom in delaying Congressional action, until it was too late, we probably would have secured Florida under his administration by a process as peaceful and noiseless, as the one by which he had secured Louisiana. At least General Armstrong, our Minister at Paris, thought and said so.

Even in his retirement at Monticello, he was still thinking of the expansion of our domain, and in one of his letters to the President, April 27, 1809, he discloses what his limit as an expansionist was: The Continent with Canada plus Cuba and there a stone to be set up inscribed "ne plus ultra."

Of course he then thought the Canadians would be more than willing.

Still, the thing desired by him is never mere domain mere dirt; - it is "an empire for liberty"! That is 
Jeffersonian-democratic-expansion. If there be any spot over which expansion does not give more room for liberty, let us none of it. There, the very air stains our flag.

There were many, who apprehended menace to our institutions from the magnitude of our territory. In this connection, read Jefferson's language in his second inaugural address: -

"I know that the acquisition of Louisiana has been disapproved of by some, from a candid apprehension that the enlargement of our territory would endanger its Union. But who can limit the extent to which the federative principle may operate effectively? The larger our associations, the less it will be shaken by local passions."

The following expression occurs in a letter to De Marbois:-

"Contrary to the principal of Montesquieu, it will be seen that the larger the extent of a country the more firm its Republican structure, if founded not on conquest, but in principles of compact and equality."

That is, of course, under a Federal system.

He held that possessing the West would hold the Union together, cementing the North and South more nearly together, because it would be inhabited by the children of both. It has had that effect. Even Missouri and Kentucky, though slave States, failed to secede. Indiana and Illinois, settled mainly by Southerners, sent their sons to the front to maintain the Union. It is not too much to say that the chief material consideration actuating them was a desire to preserve the free navigation of the Mississippi River; to permit it to "flow free and unfretted to the sea." Without 
the weight of the Middle West in the scale, we of the South would have won our independence with ease.

I do not think the wise student of history will doubt the proposition, that even if the Southern States had succeeded in maintaining a separate and independent confederacy, another war would before long have been necessary to settle disputes between the Northern and Southern Confederacies, growing out of the navigation of the Ohio, and Mississippi - certainly if the South had asserted the sole right of navigation of the lower Mississippi, which, from the very nature of things, it probably would have done.

Jefferson had drawn up in 1784 the draft, whose provision - establishing our policy of holding our territories under self-governing Congressional guardianship, while being educated for statehood - was later embodied in the ordinance for the government of the Northwest Territory. This great provision riveted on our institutions forever that policy, of governing territories - whether old or newly acquired - which we pursued to the end of the Spanish War. Out of the Louisiana Territory were carved twelve great States. When, later, territory was acquired as a result of the Mexican War, the question as to the relationship it and States already in the Union held to one another was so well settled, that it was not even questioned, and out of that territory other States were carved.

Jefferson was right; it is hard, if not impossible, to conceive of any limit to the area of country, which can be governed under a Federal model, provided: first, that the Central government leave the federated states full self-government in domestic affairs, and second, 


\section{PERMANENT INFLUENCE OF JEFFERSON}

that the Federal government itself have power to tax individuals and strength to defend the self-governing states from all foreign foes, and third, that the populations of the states be homogeneous in language, race, and love of liberty. When I say homogeneous in race, I mean that all shall be of the white or Caucasian race.

It seems to us right odd now to imagine a Federal Republic of Anglo-Saxony composed of England, Scotland, Wales and Ireland, and the several self-governing, English-speaking British Colonies, Quebec, Ontario, New Zealand, etc., and the several American States, each a sovereign state in the Federal Union. This sort of thing did not seem so strange in our early colonial history to Englishmen and some Americans. Fiske, in his "American Revolution," says truthfully that in England such a scheme was favorably regarded by Adam Smith, and in America by James Otis and Benjamin Franklin. He might have added that Pitt the elder had something like it in his head. It may be, at some time in the remote future, that such a scheme may yet evolve itself; minus a King, minus a Federal House of Lords, minus an Established National Church - in short with substantially an American Federal Republican Constitution - perhaps with a responsible British Ministry, and responsible opposition system - constituting real parliamentary government, quickly responsive to election returns - which we unfortunately do not now have, as a new graft on our system. If so, there would never be another war on the high seas, and navies would be needed chiefly to do ocean police service. Qui sait? 


\section{JEFFERSONIAN SIMPLICITY}

Jeffersonian simplicity grew out of the idea that officials are public servants and should be accessible to the citizen; that there should be no oriental mystery about republican office holders - who are to be of the people in, as well as out of, office.

Parton wrote an article, entitled "Jefferson's Return from France in 1789," which appeared in the November number of the Atlantic Monthly of the year 1872 .

He says that while in France as Ambassador, Jefferson's "family soup," as he himself called it, played a great part: "He lived in the easy, liberal style of Virginia, that harmonized as well with the humor of the time, as with his own character and habits." It was this easy, liberal style of Virginia that Jefferson hoped afterwards to make permanent in the White House.

When Jefferson reached New York on March 21, 1790, if he read the Gazette of the United States, published the day before, he was probably not a little astonished to find what follows: -

"There must be some adventitious properties infused into the government to give it energy and spirit, or the selfish, turbulent passions of men can never be controlled. This has occasioned that artificial splendor and dignity, that are to be found in the courts of so many nations. Some admiration and respect must be excited towards public officers, by their holding a real or supposed superiority over the mass of the people. ... Avarice and ambition increase with population; and in a large, opulent community the dazzling appendages and pompous formalities of courts are introduced to form a balance to the increasing ardor of the selfish passions, and to check that ascendancy which aspiring individuals would otherwise gain over the public peace and authority." 
When this same paper gave an account of the arrival of Mrs. Washington in New York on May 30, 1789, the attempt to imitate "British Court society" entries was almost childlike in its simplicity. There were noticed as present "Lady Sterling," "Lady Mary Watts," "Lady Kitty Duer," besides Lady Washington, etc. When the President attended his birthday balls themselves imitations of the Court of St. James - "a platform was reared at one end of the ballroom, a sort of dais, and upon this was a sofa," where dear, plain old George Washington of Mount Vernon plantation was persuaded to sit "reclined" with his "consort"!

This foolish movement - looking towards the establishment of pomps and ceremonies, cavalcadings, forms and frills of office in America, meant under the surface much more then than we are inclined to think now. The Senate wanted to call the President: "His Highness, George Washington, President of the United States and Protector of their liberties." The House very wisely resolved that he should be called simply "George Washington, President of the United States," and Jefferson very keenly sympathized with the action of the House. This, in the view of his enemies, is his first display of "disloyalty" to George Washington, and a betrayal of "French influence"; but the Presidents have ever since then been called plainly, "Mr. President," and no harm has come of it. Mr. Jefferson himself enjoys the rare distinction of having been generally called simply Mr. Jefferson. He wrote to Madison on August 28th and said:-

"In every instance, the new government has ushered itself into the world as honest, masculine, and dignified. It has shown 
genuine dignity, in my opinion, in exploding adulatory titles; they are the offerings of abject baseness, and nourish that degrading vice in the people."

I have thought that one of the exquisitely humorous things in our history proceeded from Senator Grayson, of Virginia, when, the Senators, being in a state of worry about proper titles to be given our high officials, he suggested that the President should be called "His Limpid Highness," and more exquisitely still, that the Vice-President should be called "His Superfluous Excellency"!

Washington wore a sword at his inauguration and at his receptions, and carried a cocked hat in his hand, so that nobody could feel encouraged to shake hands. It is needless to say that shaking hands was then, as now, the American way of expressing both cordiality and equality of intercourse. It looks childish now that men should have quarreled about these things, but it was not unreasonable that those who wanted to democratize American institutions in that day should have regarded them with suspicion. "Give a fool an inch and he will take an ell." Especially a "sas-si-e-ty" fool. The democrats knew that; and they knew the weight which would be carried in the popular imagination by conventional ceremonies, if they became stereotyped. Jefferson knew, as Napoleon did, that "the world is governed by imagination." The latter knew that republican simplicity must be sacrificed, if he was to be a real emperor; the former that it must be retained, if we were to have a real democracy. "Jeffersonian simplicity" consisted in divorcing officialdom from forms, ceremonies, and assumptions of superiority, 
and in abolishing "mysteries" of administration. Hence, when Secretary of State, he continued, on the social side of his life, his "family soups," and on the official side, introduced in the State Department that admirable simplicity and directness, which has contributed so immensely to our weight and influence in intercourse with other nations.

When he resigned the office of Secretary of State and left Philadelphia, he and Washington were on the frank and friendly terms that Virginia country gentlemen and neighbors love best to stand upon. Some of his enemies have attempted to attack the sincerity of his professions of attachment to the President, expressed in contemporaneous letters to his friends, and in his daily conversations, by calling attention to entries in other letters and in his Ana making fun of certain foolish forms and ceremonies, throne elevations, sword-by-side and cocked-hat-under-arm receptions, etc. I do not think any impartial man could doubt my sincerity of attachment to another, because I did not see fit to revere his forms and ceremonies - in this particular case, forms and ceremonies, which even St. Beuve stamps as part of a "frénésie quasi monarchique."

Earlier in his life, when about to take his seat as Vice-President, Jefferson had illustrated his dislike of public scenes. He wrote to Senator Taswell of Virginia, saying that he had heard that on the former elections of President and Vice-President, "gentlemen of considerable office were sent to notify the parties chosen," and expressed the hope that in his case "the Senate would adopt that form of notification which would always be least troublesome and most certain," the post office. 
Mr. Tucker records that so consistent was Jefferson in his dislike of empty titles, that his visiting cards never contained anything else except the words "Thomas Jefferson," no matter what office he was holding.

He announced in substance, when he became President, that he would receive people at the White House just as he would receive them at Monticello - just as a man of good breeding may receive them anywhere - on the twin principles of absolute "equality among guests," and above all, of "place aux dames."

$\mathrm{He}$ attempted to introduce republican simplicity into the official life of Washington. There was found among his papers at his death one marked, "Etiquette," worth reading, I think, both because it is curious and because it is in the main sound. This had been communicated to his Cabinet, and formed the rule of conduct of his administration.

No administration since Jefferson came in has dared to depart from the precedent of simplicity, which he set in sending a written message to Congress, to which no reply was expected. None has ever dared to attempt to restore the "speeches from the throne" made by Washington and Adams. Presidents now shake hands at receptions with their guests, as Jefferson did, and do not stand up "girded with the sword of State," with cocked hats under their arms, as snobs persuaded honest, modest, noble George Washington to do. Presidents now, with their wives, "stand upon the level" at White House receptions, and not on "a raised dais." "Sassiety" did not conquer as long as Jefferson himself was at the helm. It made up its 
mind that he should not do away with levees, so its pretty and fashionable women gathered thernselves together - and went, upon one of the regular levee days, to the White House, with a view of forcing the President's hand - he being known to be a polite man, and especially polite to the ladies. They found, however, that the wise old fox had gone horseback riding. They determined to await his return. The Master of Monticello came back, riding boots on, somewhat soiled with dust, and politely desirous "not to keep them waiting," came in just as he was. He fulsomely expressed his delight and surprise to find them there his happiness in the contemplation of the "coincidence" of their presence and his return! He greeted everybody kindly, and as each made motion to go, he urged each further to remain. The women could not help heartily laughing at themselves, and never attempted to repeat the performance. They came to capture or to ridicule. They left captured or feeling ridiculed.

The Republicans were more rejoiced at Jefferson's abolition of pomp, ceremonies, parade, and cavalcades, than they were in consequence of many other more important things. The Federalists viewed what they called "a Jacobin wreck" with alarm and despair! Little things that seem to us now, with the glamor of the past about them, interesting, if not beautiful, meant more then than they would mean now, and would have grown, by now, to mean more than they did then. Adams, unfortunately, did not see what Jefferson did, that George Washington constituted a whole class by himself.

In a chapter headed "Jeffersonian Simplicity," 
evidently put in quotation marks with a view of ridiculing the subject matter and Jefferson, Curtis opens: "The inauguration of Jefferson as President of the United States was attended with as much pomp and ceremony as the conditions would permit." I submit that this is beneath the dignity of history. If the statement had been true, it would not have made much difference; but it is not true. Jefferson carefully eschewed all pomp and ceremony, and did it for a purpose - the purpose of demolishing the "frénésie quasi monarchique." He walked from his boarding house, which was on New Jersey Avenue north, and not far from the Capitol, and a few friends, among them some Senators and Representatives, accompanied him to the Senate room to be sworn in. It is idle to say that he could not have ridden in his own coach, sent up from Monticello, or in any sort of a state coach he might have fancied to have built. It is equally idle to say that he could not have had a thousand men on horseback, if he had wanted them.

Curtis very properly exposes the story of Jefferson's going to the Capitol on horseback, and "tying his horse to the fence." This was not true for three reasons, first, because the distance was too short to make it necessary to have his horse, and, secondly, because from the best information I can get there was no fence there at that time, and third because a good horseman - and Jefferson was about the best - would not hitch his horse to a fence, if he could find a swinging limb, or even a hitching post under a shed.

After Jefferson had taken the oath, he went back to his boarding house, taking his old seat, and declining 
amid laughing protest to go to the head of the table. He stayed there several days before he went to Monticello. He rode meantime freely and unattended around Washington. Afterwards, when President, if he wanted to see a Senator or a Member of Congress, he rode up to the Capitol and saw him - hitching his horse under one of the construction sheds on the uncompleted House wing side of the Capitol; hence, perhaps by confusion, the horse was given him at the inauguration.

Jeffersonian simplicity was a real thing and not a thing to be put in quotation marks.

His "democratic simplicity," as Curtis calls it, was not "affectation," as he stigmatizes it. Jefferson was trying to teach a useful lesson to office holders in a Republic - to show that a plain man, who was elected President had nothing to do except to go on being just what he had been - a plain man - a man, "for a' that." It was the very contrary of affectation. He saw no reason why he should "affect" something new to him and therefore unnatural, just because he had been elected President. The people had'nt sent him to Washington to "put on airs."

It is said that his conduct was affected and insincere, because when Minister to France he had "lived in great elegance," and "knew better than any man in America, perhaps, the habits of European courts." It was for that very reason, that he recurred to simple habits, and it proves no inconsistency. Every man of common sense "when in Rome does as Rome does," and when Jefferson was Minister to France, he, of course, was not rustic enough not to comply, upon state occasions, with Parisian court customs. 
When he was President of these United States, he was the court!

It would have been just as absurd for him to have permitted his conduct, as chief magistrate in America, to be guided by the usages of the court of France, as to have permitted his conduct in France to be guided by "the common usages of American gentlemen."

Curtis says that "He abandoned the courtly deportment for which he had previously been noted, and adopted manners that were offensive to people of refined taste." If by "courtly deportment" is meant courtesy and genial good breeding, he never abandoned it. The manners which he carried into the White House, being the manners of "Monticello" and "Gunston Hall" and "Brandon" and "Mount Vernon" and "Rosemont," were not offensive, and could not have been offensive to anybody, except snobs.

Possibly Jefferson intended that they should be offensive to them. Perhaps, he was not entirely without intent to rebuke the tinsel Federalist "Upper-Ten," which had grown to imagine that it ruled the roast in Washington. Curtis got his ideas from reading the letters written by the left-over Federalists in Washington men and women - who were trying to decry democracy, and render it ridiculous and offensive. Some of these criticisms were brought to Jefferson's ears, and had the effect only of making him emphasize what he was already doing, and maybe sometimes over-emphasize it. Under his administration, the White House was open to all comers under the same conditions as his house on "Little Mountain" had been and would be later - subject to the master of the house not being 
engaged and the guest behaving decently. Although his receiving a British Ambassador "in slippers run down at the heels" was certainly too careless, it was, after all, a small matter, and I don't see yet why so much noise was made about it. Jefferson was Jefferson and President of the United States, whether he was in boots, shoes or slippers, and provided he was polite and courteous to the Ambassador, it was none of the Ambassador's business how he was dressed - if only within statutory limits, and certainly not a state affair.

As President, he himself at public functions asserted no precedence over governors of States, nor, for that matter, over anybody else who happened to be present. A governor having once written him to know what the etiquette would be when they should meet, he replied: "My dear Sir, there will be no etiquette." The President's residence was no longer called "The Palace."

Unfortunately, these troublesome, expensive inaugural processions that Jefferson thought to do away with, have gradually come back to plague us! It is to be hoped that some strong, wise man on being elected President will do away with them. They do no good and result generally in several deaths from pneumonia caused by exposure to the weather. They are, at best, an "idle foolish parade" - a weak imitation of "coronation" proceedings - resulting in nothing of any benefit to anybody, except a temporary increase of revenues to Washington hotels and boarding-houses and saloon keepers and street cars.

Jefferson did not want the image of a President impressed on the coinage. He did not want birthdays 
celebrated, and never would permit his own to be celebrated, where he could help it.

He seemed to be afraid of the effects of hero-worship of any description. It is the great danger of a democracy. It will remain so until the end of time. Men ought to be taught more and more to reverence laws and institutions and less and less to reverence offices and men.

I shall quote from page 122 of Merwin's "Thomas Jefferson": -

"The ascendancy of Jefferson and the Republican party produced a great change in the government and in national feeling, but it was a change, the most important part of which was intangible, and is therefore hard to describe. It was such a change as takes place in the career of an individual when he shakes off some controlling force, and sets up in life for himself. The common people felt an independence, a pride, an elan, which sent a thrill of vigor through every department of industry and adventure.

"The simplicity of the forms which President Jefferson adopted were a symbol to the national imagination of the change which had taken place. ...."

Now for substantial results of Jeffersonian simplicity in the public business. There must be, to use the words of his Inaugural Address, "a wise and frugal government." It behooved him first then to simplify our bookkeeping and to unmystify our finances - to render all plain of comprehension to the people. It was their right, because it was their money. Let us then instruct our Secretary of the Treasury.

Jefferson's letter to Gallatin, of April 1, 1801, inaugurating this reformation, is condensed by Professor Tucker as follows:- 


\section{PERMANENT INFLUENCE OF JEFFERSON}

"On the 1st of April, 1801, Mr. Jefferson addressed a letter to him on this subject, in which, after approving the secretary's plan of having one aggregate fund from which every thing was to be paid, he further suggests that all the money in the treasury should form a consolidated mass, from which the whole expenditure should be paid, and should have preference in the following order -1 . The interest of the public debt. 2. Such parts of the principal as the creditors had a right to demand. 3. The expenses of the government. 4. Such parts of the debt as the government had the right of paying. To this he proposes that degree of clearness and simplicity in the accounts that every intelligent man in the Union could readily understand them, and detect abuses. 'Our predecessors,' he remarks, 'have endeavored, by intricacies of system, and shuffling over the investigation from one officer to another, to cover everything from detection. I hope we shall go in the contrary direction, and that by our honest and judicious reformations, we may be able, within the limits of our time, to bring things back to that simple and intellectual system on which they should have been organized at first."'

As soon as possible, on Gallatin's recommendation, Jefferson authorized the sale of the United States Bank stock, owned by the government. The money was put into the sinking fund. Thus begins the dissolution of the marriage between the monied element and the government, so carefully solemnized by the Federalists.

"Now let us adjust our income and expenditures to one another!" $\mathrm{He}$ recommended the abolition of internal taxes, which shocked the Federalists - not believing that he could carry on the government without them, because they had said that they were necessary. Congress obeyed his wish, and did abolish the internal taxes, and we did get along without them, with a larger annual surplus and a larger annual payment on the public debt than had been found possible under his predecessor. 
Further pursuing his simplification of government, he urged the abolition of unnecessary offices, thereby decreasing the patronage at his disposal and, at a time, when a new and hungry party was coming into power. He promised later to lay before Congress a list of superfluous offices. This he did, and over one-fourth of the former Executive patronage was abolished.

The policy of making appropriations in "lump sums," as it has been called, he reprobated, because it carried no information to the citizens concerning the precise purpose for which the money was to be spent, and he suggested that wherever possible the purpose of the appropriation of each dollar be specifically stated in the law appropriating it. He recommended provisions which would prevent executive officers from deflecting amounts appropriated for one purpose to another, or devoting amounts appropriated in lump sum to unexpected purposes, which was really the evil struck at. To a surprising extent this evil was corrected by that Congress. He recommended placing the duty of accounting for all the public money in one department. This recommendation prevailed and is in use today: "Auditors in the Treasury Department for the Post Office Department" and "for" other departments being the instrumentality through which it is done.

While he was a candidate for the Presidency, the Federalists had everywhere said that he would repudiate the public debt. The truth is, he wanted to pay it off as rapidly as possible and Hamilton did not want unduly to hasten this process, because the outstanding debt "interested" the monied classes in the "stability" of the government, and thereby "strengthened" 
it. Jefferson proceeded at once to pay off the debt and continued its payment to its extinction, once more falsifying the predictions of his enemies.

I think I may safely say that this has become a cardinal doctrine with the party which he founded and has ever since been professed as such by its leaders, even when temporarily varied from in practice. Cleveland's first administration, 1884-88, furnished an example, almost equal to Jefferson's, of the theory and its observance.

Under Jefferson's and Gallatin's thoroughly simple and comprehensible management, the difficulty of purchasing an imperial domain, and at the same time meeting the interest and all payable principal of the public debt, was managed hand in hand with the abolition of some old taxes and without levying a single new tax or increasing an old one. It was managed upon the Jeffersonian principle of providing for the interest and the sinking fund, so that the debt might be completely satisfied within the life of a generation.

Professor Albert Bushnell Hart does not seem to be one of those who accept, without any sufficient reason for it, the legend that our present treasury system comes over from Hamilton. The truth is, that there was a marked revolution even in the method of keeping the books, and in the whole policy of the Treasury, when Gallatin went in as Jefferson's Secretary. Professor Hart well says: -

"The system established by Gallatin remains to this day, and is undoubtedly one of the most perfect organizations of a great financial machine, which can be found anywhere in the world." 
SOME MINOR MATTERS

Coinage System

Jefferson is the father of our coinage system. More justly described, his was a scheme of coinage, weights and measures, because the cardinal idea of it was the decimal system, applied equally to all three. In it he recommended the pendulum as a standard of measure. $\mathrm{Or}$, if this was difficult in practice, a measure taken at latitude $45^{\circ}$, corresponding to it. He reinforced his selection of latitude $45^{\circ}$ as the place of measuring his uniform cylindrical rod, as being a place "upon which the nations of both hemispheres might unite."

He shattered Robert Morris's proposed unit of value scheme, and succeeded in having substituted for it his own. It is the very simple and remarkably satisfactory system which we have now. His common sense suggested at once that the Spanish milled dollar, which "circulated more with us than any other coin," should be taken as the basis for both division and multiplication. This was the Spanish "Piece of Eight," $i$. e., eight bits, a bit being one-eighth of a dollar. The phrase "two-bits," meaning twenty-five cents, and "four-bits," meaning fifty cents, and "sixbits," meaning seventy-five cents, are still in use in the South, and I have seen old bookkeepers indicate on their books "eight bits" instead of a dollar.

\section{Indians}

In his time as Secretary of State he also had the duties of the present Secretary of the Interior. In this capacity, Jefferson delivered a Cabinet opinion in which 
he assumed the position that the Federal Government alone possessed the right of acquiring title to Indian lands from the Indian tribes, and that this should be done by treaty. This became a settled policy of the Government, and until within the last few years, we treated the Indian tribes as a sort of subordinated foreign powers, ceding us their lands by solemn treaty.

\section{Apportionment}

Under Washington's administration the ratio of one representative to every thirty thousand inhabitants was fixed, but when the bill for the first apportionment of Representatives in Congress passed instead of applying the ratio to each State, it was applied to the population of the entire country. Jefferson gave the President a Cabinet opinion to the effect that this violated the true intent of the Constitution, and urged an executive veto. The President agreed with Jefferson, notwithstanding Hamilton's opinion to the contrary, and vetoed the bill. The House then passed the bill, applying the ratio to the population of each State separately, and this has become the permanent custom after every succeeding census.

\section{Power of Congress over Interstate Commerce}

On February 28, 1803, Congress passed a law "prohibiting the importation of any negro, mulatto, or other person of color into any State where, by the laws thereof, their admission is prohibited," and affixing penalties for the violation of the act. Jefferson signed the act. This is curious and valuable right now, inas- 
much as it furnishes a precedent for a bill, now pending in Congress, to prohibit the importation of alcoholic stimulants into any State, where, "by the laws thereof," their sale is prohibited.

This Jeffersonian precedent is of high permanent value. Congress should not obstruct, but should coöperate with the States, when exercising their police powers for the protection of public health, or public morals, whenever Congress thinks the end, sought by the State, not violative of natural right, nor of national policy.

\section{Electoral College}

Jefferson advocated a constitutional amendment which would enable Presidents to be elected by a direct vote of the people, thus abolishing the electoral college, the people, however, voting in each State as citizens of the State, each State's vote counting to the extent of the sum of its Senators plus its Representatives. That amendment ought to be passed now. Some day we shall have trouble in the electoral college because of some elector's not keeping faith and voting as his constituents have voted. There is no law to prevent him. There is no legal penalty to which he would be subjected. There is only a pledge on honor - sometimes even that is only impliedly made.

\section{Freedom of the Press}

In his second inaugural address, after referring to the licentiousness of the press and to the calumnies and slander, etc., he announces what was his, and what ought forever to remain, the permanent policy of the Republic, by asking:- 
"Whether freedom of discussion, unaided by power, was not sufficient for the propagation and protection of truth - whether a government conducting itself in the true spirit of its constitution, with zeal and purity, and doing no acts which it would be unwilling the whole world should witness - can be written down by falsehood and defamation.".

He proudly refers to the fact that the Federalist experiment to throttle and suppress free speech and printing had been tried and failed, and to the result of the Republican experiment of the contrary theory which "had been honorable to those who served them, and consolatory to the friends of man, who believed he might be intrusted with his own affairs." You will agree that he was justified in this pæan of self-congratulation. He had kept the same faith in office that he had preached when out of it, though everybody knew that he had suffered more from the license of the press than any man, who has ever been prominent in American history, and suffered because he was not the victim of the hatred of individuals, but of classes.

\section{SUMMING UP}

Meanwhile his administration had paid off thirtythree millions of the public debt, which had been somewhat increasing before he came in; it had reduced taxes very much; it had reduced patronage, thereby simplifying the Government a great deal, and had added to the national domain the vast area of the Louisiana Territory, and put down Burr's conspiracy without war or bloodshed; so adeptly that the Federalists were beginning to deny that there ever had been a conspiracy at all; it had laid the foundations for the 
future successful contention for the possession of the Oregon country; it had benefited its own commerce and that of the civilized world by putting down the Barbary powers; it had kept the peace amid untold difficulties and with unspeakable benefit; it had captured the common sense and imagination of the country; it had destroyed quasi-monarchical forms, ceremonials, cavalcadings and "demnition nonsense" generally; it had given a practical illustration of the fact that government can be carried on successfully without tying to itself the monied, or any other special interest, and that it could be carried on by those, who regarded it as a public trust; he had given practical demonstration of the fact that a democracy is not irresponsible or dangerous, and that restraints upon freedom of speech and of the press are not necessary to make a government strong; he had put the example of George Washington in declining a third term upon a basis of reason and general principle, destined to appeal for all time to the American people, and although his embargo policy had pressed hard upon the navigating States, the pressure had been no harder, nor the dissatisfaction any greater, than war would have brought in its train, as was afterwards demonstrated. 


\section{CHAPTER VII}

\section{JEFFERSON'S INFLUENCE ON FREEDOM OF RELIGION IN AMERICA}

IN connection with his devotion to the cause of freedom of religion and speech, and to the idea that government ought not to attempt to stifle the expression of opinion, but that church and state should be separate, this is worth quoting from Jefferson's "Notes on Virginia":-

"It does me no injury for my neighbor to say there are twenty gods, or no God. It neither picks my pocket nor breaks my leg." ... "It is error alone which needs the support of government. Truth can stand by itself. Subject opinion to coercion and whom will ye make your inquisitors? Fallible men, governed by bad passions, by private as well as public reasons. And why subject it to coercion? Difference of opinion is advantageous to religion. The several sects perform the office of censor morum over each other. Is uniformity attainable? Millions of innocent men, women and children since the introduction of Christianity have been burnt, tortured, fined and imprisoned; yet we have not advanced one inch towards uniformity. Let us reflect that the earth is inhabited by thousands of millions of people; that these profess probably a thousand different systems of religion; that ours is but one of the thousand; that if there be but one right, and ours be that one, we should wish to see the nine hundred and ninety-nine wandering sects gathered into the fold of truth. But, against such a majority, we cannot effect this by force. Reason and persuasion are the only practicable instruments. To make way for these, free inquiry must be indulged by them; and how can we wish others to indulge it, while we refuse it ourselves?." 
Such utterances as these form no small part of the permanent influence of Thomas Jefferson upon American "Church and State" thought. Nothing in Milton's "License of Public Printing" is more eloquent. Scarcely anything in Victor Hugo is more shortsentence-pithy. It was a decade probably after this utterance before he had stamped its essence upon the statute books of Virginia in the first written statute that the world ever knew, granting not toleration only, but absolute freedom of religion, and not only to all sects of Christians, but to all people.

Again Jefferson wrote:-

"I never will by any word or act bow to the shrine of intolerance, lor admit a right of inquiry into the religious opinions of others. On the contrary, we are bound - you and I, and everyone - to make common cause, even with error itself, in order to maintain the common right of freedom of conscience. . . . For this reason, were my opinions up to the standard of those who arrogate the right to question me, I would not countenance that arrogance by descending to explain."

Jefferson's views about the church are not more radical than those of Emerson. As the editor of the New England Magazine says:-

"The curious thing about it all is that the pulpit fulminated as it did against Jefferson and let Adams alone, for as Parton truthfully says, "there was not a pin to choose between the heterodoxy of the two candidates."

Why the difference? The answer is obvious. Jefferson legislated disestablishment and the loss to the clergy of glebes and salaries. John Adams never did though he once said with a spirit of hate that Jefferson never felt and therefore never indulged in: "Until this 
awful blasphemy [the doctrine of the Trinity] be got rid of there will never be any liberal science in the world." But it was not until 1834 that church and state were completely divorced in Massachusetts.

Having, as I have shown in a previous chapter, dealt a great blow in Virginia for the freedom of the land and for freedom of social life from special privilege and incumbrance, Jefferson next dealt one in favor of freedom of faith and worship. He was a member of the standing committee of the Virginia House on religion, a committee which was directed to "meet and adjourn from day to day, and take under their consideration all matters and things relating to religion and morality, with power to send for persons, papers and records." Upon this committee, as in the House of Delegates itself, the established church of Virginia predominated. Jefferson here began his resolute work for the declaration of the principles, which were afterwards expressed by him in the Bill for Religious Freedom, throwing off the domination of the church in Virginia, as the bills for the abolition of primogeniture and entail had thrown off the domination of the great families.

The curious inquirer may read what Jefferson says in his "Memoir" and in his "Notes on Virginia" on this subject; how the church had shown at once intolerance and incompetency, how the laws had been adapted to the purposes of the church by making heresy a capital offence, punishable by burning, and by very many other less, but oppressive penalties. Happily for Virginia, these laws were more honored in the breach than in the observance. The history of the slow and 
gradual steps by which ecclesiastical influence in state affairs and political influence in church affairs were destroyed in Virginia is very interesting and it will pay any student to make a special study of it. It was a step-by-step performance, leading up through a series of years to the gradual climax, which was the Bill for Religious Freedom, concerning the authorship of which Jefferson took so much pride, that he had it inscribed on his tomb, as one of the three things, because of which he wanted to be remembered.

Under the Virginia Act of Assembly of 1705, if a person brought up in the Christian religion denied the being of a God, or denied the Trinity, or denied the Christian religion to be true, or denied the Scriptures to be of Divine authority, he was punishable, first, by deprivation of the right to hold office or employment; on the second offense, by disability to sue or to inherit, or to take any gift or legacy, etc., and by three years' imprisonment without bail. If the offender were a father, he was deprived of the right of the custody of his own children. The first step was to repeal the laws, which rendered criminal the maintenance of any religious opinions, or the failure to attend church, or the exercise of any mode of worship except that of the established church. The next was to exempt dissenters from contributions to the support of the established church. The next was to suspend levies on the members even of the established church for the salaries of their own ministers; but this last was limited in its operation until the next session of the House of Delegates. Jefferson's opponents, however, on November 19th, passed a declaration asserting that 
"assemblies ought to be regulated," and that "legal provision ought to be made for the succession of the clergy, and for superintending their conduct;" in other words, a legal declaration of the wisdom and righteousness of a qualified union of church and state. Permission was later secured for any person paying an assessment for the support of the clergy to designate a pastor of his choice, even though not a member of the Established Church, to whom his proportion of the assessment should go.

On the 15th the House agreed that the compulsory levies to support the established clergy should again be suspended for another session.

Thus, toe to toe, the pulling match continued the disciples of liberty now losing, now gaining ground. Up to the time Jefferson left the Virginia Legislature, he had not yet accomplished his full purpose. He left his statute for Religious Freedom on strong ground, as a legislative legacy to his friends, and they finally won it. The law as it appears upon the statute books of the State of Virginia is not word for word as it was drawn by Jefferson. The changes were verbal. The words of the bill, as given in the "Notes on Virginia," are not the words of the original, but of the bill as amended, and as it was passed by the General Assembly. The original bill may be found in Randall's "Life of Jefferson," volume 1, pages 219 and 220, with the parts which the Legislature of Virginia struck out in italics, and the parts which they added in brackets, and some alterations placed in the margin. I will excerpt a part only of this great instrument, with the italics, brackets and marginal notes which go with it: 


\section{"A Bill for Establishing Religious Freedom.}

"Well aware that the opinions and belief of men depend not on their own free will, but follow involuntarily the evidence proposed to their minds; that Almighty God had created the mind free, and manifested His supreme will that free it shall remain by making it altogether insusceptible of restraint; that all attempts to influence it by temporal punishments or burdens, or by civil incapacitations, tend only to beget habits of hypocrisy and meanness, and are a departure from the plan of the Holy Author of our religion, who being -Lord both of body and mind, yet chose not to propagate it by - coercions on either, as was in His Almighty power to do, but to extend its influence on reason alone; that the impious presumption of legislators and rulers, civil as well as ecclesiastical, who being themselves but fallible and uninspired men, have assumed dominion over the faith of others, setting up their own opinions and modes of thinking as the only true and infallible, and as such endeavoring to impose them on others, hath established and maintained false religions over the greatest part of the world, and through all time; that to compel a man to furnish contributions of money for the propagation of opinions which he disbelieves and abhors, is sinful and tyrannical; that even the forcing him to support this or that teacher of his own religious persuasion, is depriving him of the comfortable liberty of giving his contributions to the particular pastor, whose morals he would make his pattern, and whose powers he feels most persuasive to righteousness, and is withdrawing from the ministry those temporary rewards, which proceeding from an ap- temporal probation of their personal conduct, are an additional incitement to earnest and unremitting labors for the instruction of mankind; that our civil rights have no dependence on our religious opinions, any more than on our opinions in physics or geometry; that, therefore, the proscribing any citizen, as unworthy the public confidence, by laying upon him an incapacity of being called to (the) offices of trust and emolument, unless he profess or renounce this or that religious opinion, is depriving him injuriously of those privileges and advantages to which, in common with his fellow-citizens, he has a natural right; that it tends also to corrupt the principles of that very religion, it is meant to encourage, by bribing, with a monopoly of worldly honors and emoluments, those who will externally profess 
and conform to it; that though indeed those are criminal, who do not withstand such temptation, yet neither are those innocent, who lay the bait in their way; that the opinions of men are not the object of civil government, nor under its jurisdiction; that to suffer the civil magistrate to intrude his powers into the field of opinion and to restrain the profession or propagation of principles, on (the) supposition of their ill tendency is a dangerous fallacy, which at once destroys all religious liberty, because he being of course judge of that tendency will make his opinions the rule of judgment, and approve or condemn the sentiments of others, only as they shall square with, or differ from, his own; that it is time enough for the rightful purposes of civil government for its officers to interfere, when principles break out into overt acts against peace and good order; and, finally, that truth is great and will prevail, if left to herself; that she is the proper and sufficient antagonist to error, and has nothing to fear from the conflict, unless by human interposition disarmed of her natural weapons - free argument and debate; errors ceasing to be dangerous when it is permitted freely to contradict them.

therefore ed by the xeneral ssembly

"We, the General Assembly, do enact, That no man shall be compelled to frequent or support any religious worship, place or ministry whatsoever, nor shall be enforced, restrained, molested, or burthened in his body or goods, nor shall otherwise suffer on account of his religious opinions or belief; but that all men shall be free to profess, and by argument to maintain, their opinions in matters of religion, and that the same shall in no wise diminish, enlarge, or affect their civil capacities.

"And though we know well that this Assembly, elected by the people for the ordinary purposes of legislation only, have no power to restrain the acts of succeeding Assemblies, constituted with powers equal to their own, and that therefore to declare this act irrevocable would be of no effect in law; yet we are free to declare, and do declare, that the rights hereby asserted are of the natural rights of mankind, and that if any act shall be hereafter passed to repeal the present act, or to narrow its operation, such act will be an infringement of natural right."

"Natural right" again; the "things of the first table!" 
Jefferson judged himself, as he did other men, wisely, when he selected, as one of the three things to be remembered about him, and to be cut into the granite of his tombstone, that he was "The author of the Virginia Statute for Religious Freedom." It was the first of its kind, for though the charter of Rhode Island proclaimed in most absolute terms, the principle of religious liberty, the same law declared this law not applicable to Roman Catholics. Maryland had been for a long time the only asylum in the British Empire where the principle of religious toleration was established. It was established there by the Roman Catholics, and the reason is not far to seek. They were seeking some place in the Empire where they could unpenalized profess their faith, and, being in a religious minority, they were compelled to grant the same liberty to others. But even in Maryland the principle of religious liberty applied only to those, who believed in the Divinity of Christ.

The next step in Jefferson's reform process discloses his trait of "taking things by the smooth handle," while never sacrificing the essential end. The church having been disestablished and freedom of religion not mere toleration, but freedom - having been secured, it remained to do justice to the old church in the case, hence his bill, entitled "A Bill for Saving the Property of the Church, heretofore by Law established," and providing that the glebes, church belongings, furniture, arrearages of debt due the church, and all church property of every description, which had come to it by private donation, "should be saved in all time to come to the members of the English church," resident 
in the parish, where the property was situated, and reciting that it could be used by them, as they chose, in support of their clergymen. This did justice, observed the sanctity of the property relation, while not militating at all against the principle of a total separation of church and state, and entire freedom of religious opinion and practice. The bill also provided that certain surplusage, accruing out of the fact that former levies had exceeded the law, should be restored to the public by being put into the poor rates of the parish, but even in this case, in order to be generous to the defeated antagonists, it was provided, that if the parish had no glebe, this surplus was to be applied to the purchase of a glebe.

In 1784 the friends of the church rallied again and made an effort to pass, as an amendment, a bill entitled: "A Bill to Establish a Provision for Teachers of the Christian Religion," by a levy of a general assessment for that purpose. To show how far their strength had been broken, however, this bill allowed each person to direct the payment of his own contribution to the church of his choice. The struggle against the reaction was fierce, but George Mason and George Nicholas and James Madison, in the absence of their chief, stood their ground and conquered, notwithstanding the strength of the churches, the landed aristocracy, and the influence of such great names as George Washington, Richard Henry Lee, and others.

George Washington, on October 3, 1785, wrote to George Mason:-

"Although no man's sentiments are more opposed to any kind of restraint upon religious principles than mine are, yet I confess 
I am not among the number of those, who are so much alarmed at the thought of making people pay towards the support of that which they profess."

This shows that Washington had not yet learned the lurking danger in any connection whatsoever between church and state, nor the great truth that men's religious opinions are things between them and God, and that the support of churches ought to rest upon the voluntary contributions of those who profess their faith.

Richard Henry Lee, on November 26, 1784, wrote to James Madison this rather remarkable protest against what I suppose he considered "theory" and radicalism: -

"Refiners may weave reason into as fine a web as they please, but the experience of all time shows religion to be the guardian of morals; and he must be a very inattentive observer in our country, who does not see that avarice is accomplishing the destruction of religion for want of a legal obligation to contribute something for its support."

In other words, there could be no motive for the noncontribution to a church except avarice, and this irreligious motive should be overcome by state compulsion. Madison and Mason secured a delay in the proposed legislation until the next session, giving as their reason a desire to submit the question to the people, thus proposing a sort of referendum. Madison then appealed to the people in a written argument, unanswered because unanswerable, and at the next session, in 1786, the proposed assessment, which was to have gone along with Jefferson's statute for religious freedom, was abandoned as hopeless, and the bill for Religious Freedom passed, with the amendments, 
which I shall now indicate. You will see from examination that the Legislature struck out this language of Jefferson's original draft, to wit: "that the opinions and belief of men depend not on their own will, but follow involuntarily the evidence proposed to their minds." I rather think they did well, because although with a perfectly unbiased and open mind, the statement is true; yet it is also true, that, in most cases, an opinion is the result as much of prejudice and environment, or heredity, or an inclination to reach a certain conclusion, as it is of evidence.

Jefferson's original draft read in the next sub-sentence: "that Almighty God had created the mind free," and then there followed this language, which the Legislature also struck out: "and manifested His supreme will, that free it should remain by making it altogether insusceptible of restraint." In this respect, the Legislature seems to have been fighting a truism. It is impossible to conceive of any way in which the human mind can be restrained. Human utterance may be; human conduct may be. A man may be forced by law to bottle up his opinion in his own mind, but the opinion itself cannot be restrained against his conviction and will.

Jefferson next recited, that God had chosen not to propagate religion by coercion either of body or mind "as was in His Almighty power to do." Then follow these words in Jefferson's draft, stricken out by the Legislature: "but to extend its influence on reason alone." In striking this out the Legislature likewise acted wisely, because the assertion begged the very question at issue. All people believing in the Divinity 
of Jesus believed that the influence of religion was extended by the grace of God, as well as by the reason of man.

As John T. Morse says in another connection, "Jefferson's pen sometimes ran away with him." Whose does not? In the next sentence to which I shall call attention it undoubtedly did so. He said in the original draft that "to compel a man to furnish contributions of money for the propagation of opinions, which he disbelieves and abhors is sinful and tyrannical." The Legislature struck out the words "and abhors," and thereby strengthened the statute. It is not necessary that a man should abhor a religion, in order that the conclusion should be rightfully reached, that he ought not to be forced to contribute to it. It is sufficient that he disbelieves in it. It is sufficient, in fact, whether he believes in it or not, that he simply does not choose to contribute.

The Legislature was indefensible in striking out the next phrase to which I am going to call attention. They showed by striking it out that they had not yet risen to the full level of the philosophy of freedom of religion, and were still staggering around in the quagmire of religious toleration. The phrase to which I refer is this: "that the opinions of men are not the object of civil government, nor under its jurisdiction." If there be a self-evident truth in the world this is one.

But it was exceedingly fortunate that the bill should have passed even as it was, nor was its strength materially weakened by the passage of these motions to strike out, nor by the several non-essential substitutions and additions, which were really only three. 
First the substitution of the word "temporal" for the word "temporary" in the sentence, "withdrawing from the ministry those temporal rewards." The word was the accustomed one, and its substitution was an improvement.

The next substitution was striking out the words, "We, the General Assembly, do enact," and substituting for them, "Be it therefore enacted by the General Assembly."

The third was to substitute the words "the power" for the word "powers."

The most remarkable thing about this statute consists in the closing clause of it, where the attempt is made to forestall and prevent any repeal of it by future legislatures, although acknowledging their power to repeal, and confessing inability to restrain the exercise of that power. The clause accomplished its end, however. It was ever afterwards considered in Virginia, that the assertion in the concluding words of the enactment, to wit: "We do declare that the rights hereby asserted are of the natural rights of mankind, and that if any act shall be hereafter passed to repeal the present, or to narrow its operation, such an act will be an infringement of natural right," were binding.

It is not too much to say that an overwhelming majority of the American people are prepared to maintain by bloodshed, if needful, that any act of any legislature, state or national, attempting to interfere with the absolute freedom of religious opinion and of religious worship is an infringement of a natural right, and that the state has no power over the matter; that it is not under its jurisdiction, except when overt acts injurious 
to the state, or to a person, or to property occur, as a consequence of religious belief, and then that it is the act which is to be punished, or restrained, and not the belief.

Not only did Jefferson's enemies accuse him of taking political views from France, but religious views, too. This is absurd to anybody who knows the history of the man's life. His religious views were entertained by him, when he was a young man at William and Mary College. They were shared by George Wythe, his good friend and law teacher, and partially shared, I am inclined to believe, by his much esteemed and beloved Professor of Mathematics. His statute for the Establishment of Religious Freedom was drawn by him years before he went to France. 'The French encyclopedists were, for the most part, unqualified atheists, and when not, were purely materialistic agnostics. Jefferson was a devout believer in the existence and the providence of God, and in a future state. I have sometimes thought that he was more nearly a Christian in his belief than any man who has lived since Christ. His Unitarianism was a reverential and a cautious, as well as a rational, belief. It was not the "sneering, leering" belief of Voltaire, which necessarily led to "a divorce of life from morals," nor Gibbon's "solemn mocking of a solemn creed" with a solemn sneer. Jefferson was afterwards charged with being an atheist, principally by the Calvinistic and Congregational priests, because they did not see any difference between a denial of the Divinity of Christ and atheism.

I have said that his belief was not only reverential, but that it was cautious. He seemed to have a sensi- 
tive fear of intermeddling with the religious belief of other people, even with that of his own children. In fact, his children and his grandchildren did not know until after he was dead, that he had prepared the socalled "Jefferson Bible." He was always most careful not to be a propagandist, but to insist that every man's belief should be formed, as his own had been, independently and on one's own dread responsibility, "not for the rightfulness, but for the righteousness of it." His beliefs were expressed in a few confidential letters to Priestley and Adams, and others, who entertained the same opinions, and, in one or two cases, they were expressed to Dr. Franklin, who likewise entertained them, but, in a cannier way, kept them to himself. These letters, for the most part, were not published until after his death. Many of his friends thought that his grandson made a mistake in publishing them, and I have an idea that Jefferson would have thought so himself. However, he left his letters and documents to his grandson, without limiting the authority to use them, as he chose.

The hatred, calumny and lies - scurrillous and cruel - visited on his devoted head for the balance of his life on account of the Disestablishment in Virginia, and because of the anger and fear arising from the justly anticipated imitation of his legislation elsewhere, are wondrous. During his campaign for the Presidency there was positively no end to the bitter denunciation. It was charged by one preacher in New England that Jefferson had "obtained his property by fraud and robbery;" that in one instance he had "defrauded and robbed a widow and fatherless children," of whose 
estate he was executor, "of ten thousand pounds sterling, by keeping the property and paying them in money at the nominal rate, when it was worth no more than forty for one," and this stupendous lie was closed with the assertion that the reverend gentleman "could prove it"!

The New England clergy seem to have adopted him as a favorite text. One, Doctor Mason, declared that Mazzei had once told a Reverend Mr. Smith, who had told him, that Jefferson had said of a ruined church: "It is good enough for him who was born in a manger." Dr. Mason also charged that Jefferson was solicitous "to wrest the Bible from the hand of the people's children."

In a letter to Dr. Rush, Jefferson said that the clergy believed that any portion of power confided, in him, Jefferson, would be exerted in opposition to all church establishment schemes. Then he adds:-

"And they believe rightly; for I have sworn upon the altar of God eternal hostility against every form of tyranny over the mind of man. But this is all they have to fear from me; and enough, too, in their opinion. And this is the cause of their printing lying pamphlets against me, forging conversations for me with Mazzei, Bishop Madison, etc."

The man's superb moral courage was shown in the fact that he dared, on coming into power as President, to remember to keep a promise to Thomas Paine made in consequence of his services to the cause of liberty in America during the American Revolution, notwithstanding the intense and almost universal hatred of Paine which had grown out of his notorious anti-religious views. Paine was then in France, where he had been coöperating with the French revolutionists, and 
where, by the way, be it remembered to his credit, he had had the courage and the good sense to vote against the king, when that was dangerous, and against the death decree pronounced upon the king, when to do that was yet more dangerous. He was in prison and would have reached the guillotine, had not Robespiere reached it first. He wanted to return to America, was afraid that the British cruisers might take him off a merchant ship, and had therefore asked that he be permitted passage on board a national vessel. Jefferson wrote to him:-

"You expressed a wish to get a passage to this country in a public vessel. Mr. Dawson is charged with orders to the captain of the Maryland to receive and accommodate you with a passage back, if you can be ready to depart at such short warning."

\section{In another part of the letter he says:-}

"I am in hopes you will find us returned generally to sentiments worthy of former times. In these it will be your glory to have steadily labored, and with as much effect as any man living. That you may long live to continue your useful labors, and to reap their reward in the thankfulness of nations, is my sincere prayer."

Men who have denounced Mr. Jefferson for thus affording the asylum of a war vessel to Mr. Paine, because Paine was an atheist, as they say, in almost the next breath pronounce him to be a man of gross "timidity" in the face of public opinion, and to be a persistent "demagogue seeking popularity"! The two things do not well fit into one character. Jefferson must have been the greatest fool in the world if he had not known, and as a matter of fact, he did know, that this letter to Paine and this passage on a war vessel 
extended to him, would raise a storm of popular disapproval, and unchain once more the satanic fury of the theologians and of a great many good people. Notwithstanding it all, Jefferson remembered Paine's services to the cause of liberty in America, and his manly stand at the risk of his neck in France. Not only that, but when Paine had come, Jefferson entertained him with Virginian hospitality at Monticello, and this was while the storm was blowing.

The degree to which the New England clergy hated Jefferson, and the measure in which he returned their hate, coupled with some contempt, were extraordinary. It was no wonder they hated him. First, he was of the opposite party. Secondly, there was jealousy of the rule of "the Virginia Dynasty"; New England pride was aroused. Third, he was not orthodox in religion. Fourth, he carried his lack of orthodoxy in Virginia to the point of separating the church from the state, the church being as yet, "established" and in the enjoyment of valuable special privileges throughout all New England, except in Rhode Island. Fifth, his known sympathies with the French people constituted him a "blood-thirsty Jacobin." They neither asked, nor gave quarter. They had their flocks in such condition that when Jefferson was elected President, it produced a sort of panic among many good people.

John Fiske says that he "has heard his grandmother tell how old ladies in Connecticut, at the news of his election, hid their family Bibles, because it was supposed that his very first official act - perhaps even before announcing his cabinet - would be to issue a ukase ordering all copies of the sacred volume through- 
out the country to be seized and burned." And this simply because Jefferson was a conspicuous advocate of freedom of religion, or perhaps still more because he had disconnected parsons from glebes and state support much to the improvement of true religion. He was, as it was the habit to call men in that day, a "freethinker." It is wonderful how many good, honest folk think they are thinking when they think they think that thinking freely is a sin, and ought to be made a crime. Fiske well adds that "when people get into such a state of mind, the only thing that can cure them is an object lesson."

In connection with the hatred of the clergy and preachers generally for Mr. Jefferson, growing out of his disestablishment of the church in Virginia, and the welcome which that measure had met with, and the imitation of it elsewhere, it is well for the student to remember that the support of public worship was compulsory in Massachusetts, except in a few exempt cities, as late as the year 1833. We are apt to forget facts like this now, and to forget that Dr. Childs, of Berkshire County, attempted unsuccessfully in the Massachusetts Convention of 1820 to free himself, and others, of this unjust burden. Some honest people denounced Jefferson, as "an atheist," because he was a Unitarian, or rather because - not being orthodox - he might be anything. Being God's vice-gerents in this world, they proceeded to destroy God's enemy, and especially this Philistine and Amalekite. They did not stop with attacking his political and religious views. They lent ears of easy credulity to every charge, rumor, or insinuation against his private character. They preached 
from the pulpit that he was an adulterer, a miscegenist, a demagogue, a liar, a hypocrite, and a coward. Notwithstanding all this, New England, little by little, slipped from under their control. A broad, tolerant, and free administration, a "wise and frugal government," little by little, sapped the strength of New England Federalists, whose natural leaders were the clergy. The object lesson to which Fiske referred was taught and learned.

I don't know whether Jefferson was greatest as a political manager, as so many people say and write, or not, but that he was great in this role, is undeniable. He won men over and held them not by corrupting them with patronage, nor by tying them to his administration through their monied interest, or class interest, nor by extending to anybody any special privileges, nor by any rod held over them, but by "taking things by the smooth handle," while appealing to the reason and common sense of all. Thus he rendered hurtless the arrows of intolerance and hatred which fell upon the shield of his honest intent. The odium theologicum was itself partially disarmed in reconciliation before his death.

James Parton in his article entitled "Jefferson a Reformer of old Virginia," in the Atlantic Monthly, of July, 1872, says:-

"We have come now to regard liberty of belief very much as we do liberty of breathing - as a right too natural, too obvious, to be called in question - forgetting all the ages of effort and of anguish which it cost to rescue the human mind from the domination of its natural foes."

It is for this reason that we are not apt to estimate 


\section{PERMANENT INFLUENCE OF JEFFERSON}

at its full value Jefferson's efforts, and his final triumph in obtaining the enactment of the Virginia statute of Religious Freedom. "No man ever more effectively put the case in favor of freedom of worship and freedom of opinion." "Logic, irony, good-natured appeal, were all combined." The reader will find a good deal of it in the "Notes on Virginia," being a recital for the world of the arguments that had been used so effectively in the Virginia Assembly.

Jefferson later followed up the work in this cause performed in his State, by insisting that the United States Constitution should be amended by the inclusion of a bill of rights, and as a part of it, a clause forever debarring the Federal Government from the establishment of a religion. In the western States the Virginia example of a complete separation of church and state, like most Jeffersonian examples, was universally and at once followed.

Jefferson's definition of a church is interesting:-

"A voluntary society of men, joining themselves together of their own accord, in order to the public worshiping of God, in such a manner as they judge acceptable to Him, and effectual to the salvation of their souls. It is voluntary because no man by nature is bound to any church. The hope of salvation is the cause of his entering into it. If he finds anything wrong in it, he should be as free to go out, as he was to come in."

Upon the subject of the separation of church and state, he said: -

"The people have not given the magistrates the care of their souls, because they could not. They could not because no man has the right to abandon the care of his salvation to another. The opinions of men on religion are not the subject of civil government, nor under its jurisdiction." 
During his stay in Paris his "Notes on Virginia" were published - a pirated edition. Parton says: "Saturated as the book was with the republican sentiment of which he was the completest living exponent, it was eagerly sought after in Paris, and had its effect upon the time." "In France, too, during his stay there, his 'Act for Freedom of Religion' was printed, this time at his own instance."

Instead of the old laws against witcheraft - which had existed not in New England alone, as some people from the way they talk seem to think, but also in old England and in Virginia - Jefferson substituted this in Virginia: -

"All attempts to delude the people, or to abuse their understanding by the pretended arts of withcrafts, conjuration, enchantments, or sorcery, or by pretended prophecies, shall be punished by ducking or whipping, at the discretion of a jury, not exceeding fifteen stripes."

In other words, instead of punishing anybody for being a witch, the punishment was meted out to those who pretended to be witches! Thus anybody in Virginia to be innocent of witchcraft had only to deny his "witchship," and to be guilty must be liar and fraud enough "to pretend witchcraft!" To wipe out a superstition by a piece of legal irony like that, approaches humor, though Jefferson's was not a humorous character. 


\section{CHAPTER VIII}

\section{JEFFERSON'S INFLUENCE ON OUR EDUCATIONAL}

INSTITUTIONS

\section{To George Wythe Mr. Jefferson wrote, in August,} 1786:

"Preach, my dear sir, a crusade against ignorance; establish and improve the law for educating the common people. Let our countrymen know that the people alone can protect us against these evils; and that the tax which will be paid for this purpose is not more than the thousandth part of what will be paid to kings, priests, and nobles, who will rise up among us, if we leave the people in ignorance."

I quote this because it is a keynote expression of the Jeffersonian doctrine that democracy and education are interdependent and that from their blissful marriage proceeds "the happiness and freedom of man."

Harvard University had conferred on Mr. Jefferson, while in France, the degree of Doctor of Laws. In his letter of acceptance, addressed to Dr. Willard, this everlasting educational basis for all his theories appears again. He says: "We have spent the prime of our lives in procuring for them [that is, the young men of the country - the students at the colleges] the precious blessing of liberty. Let them spend theirs in showing that it is the great parent of science and virtue; and that a nation will be great in both, always in proportion as it is free."

Dr. James C. Carter truthfully says that "Jefferson s educational scheme was part of his political phi- 
losophy," being aidful to man's self-government and indispensable to the freedom and happiness of mankind, because he believed that no nation or community "could permanently retain this blessing [of liberty] without the benefit of the lessons of truth."

Jefferson stated the objects of primary education as he understood them, with a comprehension and just appreciation unexcelled:-

1. "To give to every citizen the information he needs to transact his own business.

2. "To enable him to calculate for himself and to express and preserve his ideas, contracts and accounts in writing.

3. "To improve, by reading, his faculties and morals.

4. "To understand his duties to his neighbors and his country, and to discharge with competence the functions confided to him by either.

5. "To know his rights; to exercise with order and justice those he retains; to choose with discretion the fiduciary of those he delegates, and to notice their conduct with diligence, candor and judgment.

6. "And, in general, to observe with intelligence and faithfulness all the social relations under which he shall be placed."

Dr. Carter said of this statement, that it "ought to be written in letters of gold and hung in every primary school throughout the land and be known by heart to every teacher and child."

As early as 1778, while we were still in the throes of revolutionary travail, Jefferson presented to the Legislature of his native State a bill outlining the scope and establishing the means of inaugurating common schools, grammar schools and a State university. From that time on, no matter where he was, no matter how much occupied with public duties, his mind was continuously recurring to that scheme, and in a letter 
dated June 4, 1786, addressed to General Washington, Jefferson expressed the opinion, that, "nothing but the extreme distress of our resources" prevented that scheme from being carried into execution, "even during the war."

Nor were his views of education narrow. The chief end in his mind was to equip for citizenship - practical and utilitarian here, as always - but the scope of the preparation that he would make for citizenship included learning of almost every sort.

Throughout his whole life he was singularly neglectful, if not defiant, of authority. This enabled him to see the folly of the old four class system - Freshman, Sophomore, Junior and Senior - and substitute for it separate, independent and yet interlocked schools, each specializing in a given subject. He saw no reason, for example, why a man, who wanted to study civil engineering, should be first forced to show a certain degree of proficiency in Latin, or Greek, and he saw, as most men now do and few then did, that, although the classics were a beautiful study, refining the taste and improving the intellect, there was still no reason why they should so nearly monopolize the field of education.

Returning to the report of the Law Revisers; it contained a general plan of education for the State constituted of three bills drawn by Mr. Jefferson, one entitled, "For the more general Diffusion of Knowledge, by establishing Common Schools and Grammar Schools;" the second, "For Amending the Constitution of William and Mary College and Substituting more certain Revenues for its Support:" and the third, "For establishing a Public Library." 
The preamble of the bill to establish Common and Grammar Schools goes upon the ground that it is not only the right, but the duty, of a State to make proper provision for the education of the children of the commonwealth. Each county was to have three officers called "aldermen"; to be divided into "hundreds"; in each "hundred" there was to be a military company and a school. It was made the duty of the inhabitants of each "hundred" to erect and repair suitable schoolhouses. In these all children were entitled to receive tuition free for three years, and weie entitled to attend the school as much longer thereafter as they chose, provided their parents paid for their attendance. The subjects taught were to be the "three Rs" - reading, writing and common arithmetic; and it is characteristic of Jefferson that when he came to the subject of reading, he provided that the books to be read were to be such "as would at the same time make them acquainted with Grecian, Roman, English and American history." The wise old fox knew that Virginia was not yet up to the mark of taxing the rich planters to teach history free to the children of the poor, if indeed she were up to the mark of taxing them to teach anything free. But history, next to mathematics and natural science, was his own favorite study. It was moreover, in his opinion, the most useful of all studies to free citizens under a popular government.

Every ten schools were to have over them an "overseer," who, in Jefferson's words, was to be "eminent for his learning, integrity and fidelity to the Commonwealth." I don't suppose that anybody but Jefferson 
would have thought of testing a teacher's fitness by his "fidelity to the Commonwealth," but he was right, in a broad way.) This overseer had the power of appointment and removal of teachers.

Next comes his provision for Grammar or Central Schools. The State was to be divided into twenty districts, and the Board of Overseers, constituted of all the overseers of all the counties contained in each district, was to procure a hundred acres of land, situated as nearly as practicable in the center of the district, upon which were to be erected buildings of stone or brick, for the central academy or grammar school. These buildings were to contain at least a school room, a dining room, four rooms for master and usher, and ten or twelve lodging rooms. / To these schools were to be admitted for free tuition and free board the brightest pupils of the common schools, as shown by their records, thus "carrying the talents of the State up by a process of selection, from the lowest to the highest" schools, because there was also a provision made by Jefferson for carrying the brightest of each grammar or central academy school boys, as shown by their records, up to the State University; all this "selected talent," as it was thus "carried up," being educated and boarded gratis. In these grammar schools, or central academies, were to be taught Latin, Greek, English, English Grammar, history, geography, and the higher mathematics.

Each overseer, in obedience to this theory of "selection of talents," was to act "after the most diligent and impartial examination and inquiry," under oath, and "without favor or affection." At the end of each year 
the Visitors were to cull out one-third of the least promising of these common-school-selected pupils and discontinue their free board and tuition at the grammar school. At the end of the second year of free board and tuition at the grammar school, all of them thus sent up were to be discontinued, except one from each grammar school district, who was to be the one of the greatest merit, who was permitted to remain four years longer, and after that, if he passed, he was to be deemed a "senior." Now from these seniors, thus arrived at by process of "survival of the fittest and extinction of the unfit," the Visitors were each year to select one and send him with free board and tuition to the State University.

2. "The Bill for Amending the Constitution of William and Mary College and Substituting more certain Revenues for its Support," that is, making it a State University, first and cardinally, did away with religious tests for professors and students. Because of this it was never enacted. Church influence at William and Mary was too strong. It was by its charter a Church of England School, and inclination ran with the provisions of the charter to prevent the abolition of religious tests for teachers and even for pupils. Thus William and Mary missed being the State University.

3. His Bill for establishing a Public Library appropriated two thousand pounds a year to purchase books and maps. It failed at that time. but a similar law, based on it, passed in 1822-1823.

Girls as well as boys were to be admitted to Jefferson's common schools. In this Henry G. Boutelle says that he was "ten years ahead of Boston." 
Never surrendering an idea, Jefferson began to work on the project of a State University elsewhere than at William and Mary, with these cardinal, and at that time, for the most part, novel features: -

"Freedom of teaching in independent elective schools - by Professor's Lectures.

"Freedom of Study - Student selects his 'ticket.'

"The Honor System - No espionage - Freedom of conduct under obligation of observing the laws of the State and the United States.

"Proficiency in intermediate and final examinations - not class attendance, not daily examinations, nor time spent, nor degrees attained elsewhere - brought degrees, at Jefferson's University. "No gradations in a degree - all cum laude or none, $(80 \%-75 \%$ necessary to pass).

"No honorary degrees.

"Degrees to bear English, not Latin names - Master of Arts etc. "No rewards - no college honors - except a certificate of having passed examination in the 'school,' or a number of examinations in a number of schools, entitling to a prescribed degree.

"No compulsory attendance on prayers or service. Each denomination to send a clergyman for two years, who conducts daily prayers and Sunday service." (They are well attended and the preacher is paid by voluntary contributions of students.)

All of which were later engrafted on the University of Virginia at Charlottesville.

Jefferson was a stickler for educating women, but not precisely as men. His general principles were:-

1st. "A solid education to enable them to educate their own daughters.

2nd. “Then special studies $\left\{\begin{array}{l}\text { Dancing, } \\ \text { Music, } \\ \text { Poetry, } \\ \text { Household economy." }\end{array}\right.$ 
Jefferson held that the chief use of education was to fit a man for citizenship. Hence the common school, and, to some extent, the grammar school - the education of the masses - was (because they are all one) the backbone of his system, but he was just as fixed in his opinion, that there ought to be also a University school for the people - a State University. The permanent influence of Mr. Jefferson upon public institutions has nowhere been more pronounced or more beneficial than in this. His idea was taken up by his disciples in Michigan and a State University school for the people established there, even before Jefferson had succeeded in consummating his plans in Virginia.

Judge A. B. Woodward, his friend, whom he had appointed Chief Justice of Michigan Territory, created a university in the wilderness on Jefferson's plan, before Jefferson could open the University of Virginia; no religious creed to be taught - professors to hold positions for ten years - a Jesuit priest and a Presbyterian minister working together in the faculty - the beginning of our priceless heritage of universities free from shackles on thought.

E. P. Powell says of this Michigan University:-

"It was Jeffersonianism worked out to a finish."1

"The fact of forty State universities. . . each ambitious to excel, and becoming more completely every year the head and centre of a complete state system, is one of the grandest features of American institutional development."

1 "Jefferson and Hamilton in our Education," New England Magazine, 1896, n. s., Vol. 14, page 702.

2 Same, page 703.

19 


\section{PERMANENT INFLUENCE OF JEFFERSON}

\section{Powell adds: -}

"This we owe to that master mind that stood beside Washington in the hour of the nation's birth ... the brilliant imagination that foresaw the moral and intellectual needs of a vast republic, as well as its political needs."

A university's purpose, according to Jefferson's notion, was "to make men fit to be wise citizens," and to equip able statesmen, or men able to select statesmen - "to train men to be judges, legislators, diplomats, farmers, scientists, teachers, manufacturers" in other words, successful laborers in the vineyard of human progress.

Then add Jefferson's idea of Theological Seminaries near by, erected and paid for by the churches, and enjoying the benefit of the tuition of the university schools, and their pupils meeting in these schools, so as to wear away sectarian prejudices, all emulating one another in the conception and practice of true Christian and unsectarian morals. The churches never availed themselves of this privilege.

It is too long to quote in detail, but I refer the student to Jefferson's report of June 6, 1818, drawn by him and signed not only by him, but by Madison and Monroe and Cabell, upon the establishment of a State University. It is one of the ablest and most interesting of his state papers. This much of it I will quote:-

"By a bill of the last session, passed by one branch, and printed by the other for public consideration, a disposition appears to go into a system of general education, of which a single University for the use of the whole State is to be a component part. A purpose so auspicious to the future destinies of our country, which would bring such a mass of mind into activity for its welfare, cannot be 
contemplated without kindling the warmest affection for the land of our birth, with an animating prospect into its future history. Well directed education improves the morals, enlarges the minds, enlightens the councils, instructs the industry, and advances the power, the prosperity and the happiness of the nation."

He was no orator, but here, as in the Declaration of Independence and in the First Inaugural Address, he is eloquent. As a result of this report a bill was passed, which gave authority for the foundation of the University of Virginia, whereunder Jefferson and some others, including Madison, were appointed members of a commission to determine upon a suitable place for it. Mr. Jefferson's report to the Legislature, as Chairman of this commission, is one of his greatest state documents. In it he undertook to delineate the work of the lower schools - common schools - and that of the grammar schools and colleges, which were to be "institutions intermediate between primary schools and the University," and of the University itself.

Upon a meeting of the Board of Visitors constituted by the Act, under the authority reposed in them, they selected Thomas Jefferson as Rector of the University. From that time on the University became his pet and almost the complete monopolist of his time and attention.

It has been said that Jefferson had no imagination. If it be meant by this that he had none of the romantic tinge, it is perhaps true, but he had constructive imagination of the highest order. $\angle \mathrm{He}$ planned, not for what was then needed, but for a greater future than his or any other University in America has yet enjoyed, although the work of his own has been of the most 
thorough and the most useful sort. $\mathrm{He}$ said, in a report of November 29, 1821, to the Directors of the Literary Fund:-

"We had, therefore, no supplementary guide but our own judgments, which we have exercised conscientiously, in adopting a scale and style of building, believed to be proportioned to the respectability, the means, and the wants of our country, and such as may be approved in any future condition it may attain. We owed it to it to do, not what was to perish with ourselves, but what would remain, to be respected and preserved through other ages, and we fondly hope that the instruction which may flow from this institution, kindly cherished, by advancing the minds of our youth with the growing science of the times, and elevating the views of our citizens generally, to the practice of the social duties and functions of selfgovernment, may ensure to our country the reputation, the safety and prosperity, and all the other blessings, which experience proves to result from the cultivation and improvement of the mind; and, without going into the monitory history of the ancient world, in all its quarters, and at all its periods, that of the soil on which we live, and of its occupants, indigenous and immigrant, teaches the awful lesson, that no nation is permitted to live in ignorance with impunty."

It has been urged by some critics that Mr. Jefferson had the idea of a university only for a State, while Washington's "grander conception" had gone to a national university. I am not one of those who believe that a great national university, overshadowing the State universities, is the best in the long run for the country. I think that each State of this Union, as it becomes more densely settled, will have sufficient means readily to furnish its citizens with a great university, equal to anything in Europe, in its scope, its thoroughness, its teaching faculty, its apparatus, and its architecture, and that the establishment of a 
great national university would discourage the growth towards perfection of the State institutions. But, as it happens, this opinion of mine Mr. Jefferson did not share, thus, as usual, putting his critics to shame for, in his sixth annual message to Congress, he urged the foundation of a university at Washington, saying, in answer to obvious arguments of the old school against it: "A public institution can alone supply those sciences which, though rarely called for, are yet necessary to complete the circle, all the parts of which contribute to the improvement of the country, and some of them to its preservation."

I believe that the Federal Government has taken over so many things that it has resulted in the States waiting on it for nearly everything. If the dreams of Washington and Jefferson had been realized early in our history, the great and splendidly conducted State universities, now within easy reach of nearly every citizen's boy, would never have been born, and the older privately endowed institutions, like Harvard, and Yale, and Princeton, and King's or Columbia, already born, would have lagged behind in the race, overshadowed and becoming more and more comparatively incompetent to aid in the great higher educational work of the land, and possessing from generation to generation less and less the confidence of the student body and the faculty body of the Union.

In Jefferson's educational report, written from Fish Gap Inn, August 1, 1818, to which I have already referred, there are some things the reading of which may or may not tire your patience, but they are so sound, so full of common sense, so far from doctrin- 


\section{PERMANENT INFLUENCE OF JEFFERSON}

airism, of which take-things-on-trust writers always accuse him, that I shall adventure it:-

"And this brings us to the point at which are to commence the higher branches of education, of which the Legislature requires the development; those for example, which are:-

"(1) To form the statesmen, legislators and judges, on whom public prosperity and individual happiness are so much to depend;

"(2) To expound the principles and structure of government, the laws which regulate the intercourse of nations, those formed municipally for our own government, and a sound spirit of legislation, which, banishing all arbitrary and unnecessary restraint on individual action, shall leave us free to do whatever does not violate the equal rights of another;

"(3) To harmonize and promote the interests of agriculture, manufactures and commerce, and by well-informed views of politcal economy, to give a free scope to the public industry;

"(4) To develop the reasoning faculties of our youth, enlarge their minds, cultivate their morals, and instill into them the precepts of virtue and order;

"(5) To enlighten them with mathematical and physical sciences, which advance the arts, and administer to the health, the subsistence, and the comforts of human life;

"And, generally, to form them to habits of reflection and correct action, rendering them examples of virtue to others, and of happiness within themselves.

"These are the objects of that higher grade of education, the benefits and blessings of which the Legislature now proposes to provide for the good and ornament of their country, the gratification and happiness of their fellow-citizens, of the parent especially, and his progeny, on whom all of his affections are concentrated."

Jefferson's plan held out, as we have seen, prizes in each of the grades of the educational system, to an honored place in the next higher grade which would be not only of material value to those who succeeded in obtaining them, but of mind-training value to those 
who unsuccessfully competed for them, and perhaps of still greater aspiration value to the general body of pupils and students as fixing an ideal educational esprit du corps.

In this report of 1818 to the Legislature of Virginia Jefferson, among other things, says:-

"Education generates habits of application, of order, of the love of virtue, and controls by the force of habit any innate obliquities in our moral organization. We should be far, too, from the persuasion that man is fixed, by the law of his nature, at a given point; that his improvement is a chimera, and the hope delusive of rendering himself wiser, happier, or better than our fore-fathers were. As well might it be urged that the wild and uncultivated tree, hitherto yielding sour and bitter fruit only, can never be made to yield better; yet we know that the grafting art implants a new tree on the savage stock. ... . It cannot be but that each generation, succeeding to the knowledge acquired by all those that preceded it, adding to it their own acquisitions and discoveries, and handing the mass down for successive and constant accumulation, must advance the knowledge and well-being of mankind, not infinitely, as some have said, but indefinitely, and to a term which no man can fix and foresee."

¿A great system of state-supported common schools, academies and universities, in a government where all men are accounted equal, gives to the poor, as well as to the rich, the opportunity of developing their talents, and does it in institutions without class bias. $J$ Some universities and colleges have a spirit which would subject man's mind, by limiting free range of thought, and some others resting upon private endowments, even in our own country to-day, are permeated with the distinct bias of plutocracy. A selfish and designing plutocracy can give Jefferson's "kings, nobles and priests" of the opening quotation of this chapter two 
points in every game of three and still nearly always win.

He was happy in calling attention to the fact, that the benefits of colleges and universities are not monopolized by students within their walls. Every man goes out as a practical teacher in that walk of life, which he is to tread - to the advantage of all with whom he comes in contact.

Jefferson, throughout his whole life, was pretty strong in preambles to bills. The preamble to his Bill for the Better Diffusion of Knowledge, in 1779, is as follows: "And to avail the Commonwealth of those talents and virtues, which nature has sown so liberally among the poor as the rich, and which are lost to their country by the want of means for their cultivation; Be it further enacted," etc. Queer language for a dry statute, but characteristic of Jefferson! What follows, too, occurring in a letter written to Dr. W. T. Barry on August 4, 1822, is characteristic. LAfter complimenting Barry on what had been done in the Legislature of Kentucky for popular education, he says: "A popular government, without information or the means of acquiring it, is but a prologue to a farce or a tragedy; or perhaps both. Knowledge will forever govern ignorance." Even the early abolitionists and the doctrinaires and the theorists of "reconstruction," who frequently mistook Jefferson for their apostle, without fully understanding either him or why, learned that lesson in the course of time.

In one of Jefferson's letters to Adams, written in 1813, he speaks of an educational system as "the keystone of the arch of our Government." 
(And to Joseph C. Cabell, two years afterwards, he wrote: -

"Were it necessary to give up either the Primaries, or the University, I would rather abandon the last, because it is safer to have a whole people respectably enlightened, than a few in a high state of science, and the many in ignorance. This last is the most dangerous state in which a nation can be."

And yet I heard a critic once say that it was "characteristic of the South and Southern statesmen" that Jefferson should have spent time and wasted fortune in building a university in a State without a compatible system of free schools, with the idea that "if a few people were highly cultivated," civilization and the State would be in the best possible condition!

As the democratic support, which he had received in his great work of making-over the American soulpolitic, had had its surest strength in Virginia and in Kentucky, he never ceased to admonish all Virginians and Kentuckians to take up the great work of popular education, and if they did not heed his admonitions to the extent to which they ought to have heeded them, it is but another instance of "a prophet not without honor save in his own country!" The great West took it up, "the country beyond the mountains," as he was fond of calling it, where Jefferson was beloved and confided in, as perhaps no man of our entire history ever was, and in the acts of their legislatures and by the great burden of taxation which they have voluntarily borne, they have echoed his language: "No other sure foundation [than education] can be devised for the preservation of freedom and happiness." Michigan, Minnesota, Iowa, Illinois and Indi- 
ana were early in the field; Michigan, as we have seen, by the direct inspiration of Jefferson; Kentucky, also, under his direct inspiration, founded the Transylvania University, from which great things were expected, but which the slaveholders' poverty, because of inefficient labor, and his lack of sympathy with an educated common people permitted much to decay and languish.

Jefferson never showed greater contempt for authority than in his organization of the University of Virginia. He not only put modern languages upon an equal footing with Latin and Greek and Applied Mathematics on a footing with pure mathematics, but he insisted on teaching all applied sciences. He organized a university of separate and independent schools, where a boy who had a particular reason for wanting to study French, for instance, could study French without having to be first examined in mathematics or something else, and a boy who wanted to fit himself to be an Architect or a Civil Engineer could take up the mathematics leading to that profession and the art itself, without having to show that he knew Latin or French schools which might be entered by any one, provided only he knew enough to take up the work in that school, where it began at the University. Not only that, but he left each student free - not comparatively, or in a modified way - but absolutely - to study just what he wanted to study, and he buttressed the freedom of teaching, as it was buttressed in no other institution each professor in each school being the judge of how he should teach, and teaching by lecture. This sort of school was especially adapted to the condition of the South and Southwest at that time. 
It was assumed that a boy fit to enter a university knew the importance of mastering his work, and also knew beforehand, at that particular institution at any rate, that, unless it was thoroughly mastered, he could not possibly pass the only tests, two examinations, one intermediate of the term called the Intermediate and the other at the end of it, called the Final.

I once heard a man say that he who was not master of the Greek subjunctive could not possibly have his mind trained. I never dispute with a dogmatist, but I thought to myself that the complete mastery of the German, or even the English, subjunctive was a thing "not to be sneezed at." In addition to the fact that Latin and Greek have been made a fetish of, they have been mistaught. They ought to be taught to children, as German and Italian are, from easy primers up, and to a large extent, objectively - conversationally by pointing out things with their names. The fact is, that in the teaching of all languages some degree of fluency in vocabulary should precede the acquirement of the niceties of grammar-science.

To illustrate: There are many, doubtless, among my readers who can read German or French easily without conscious translating, after having spent from a half to a third as much time in acquiring them as was spent in procuring a more or less formal reading. acquaintance with Latin and Greek. In fact, for a while there was a superstition to the effect that civilization itself - that is, the progress of culture - depended upon the acquirement of Latin and Greek. The Japanese have dissipated that idea. It is wonderful what a progress they have made in all the arts and 
sciences and languages of modern Europe, but they left Latin and Greek out of their curricula, not because they were not worth studying, but because the Japanese had something else to do.

The United States have "gone a world-powering." Under our flag are Porto Rico and the thousand isles of the Philippine Archipelago, and yet a hundred boys probably are taught Latin in the public schools of America, where one is taught Spanish. No man was ever a greater stickler for the study of the classics than was Mr. Jefferson, but he was never superstitious about it, and never had the notion that an American boy ought to be prevented from studying other things simply because he had not studied them. In his "Notes on Virginia," he says: "The learning Greek and Latin is going into disuse in Europe. I know not what their manners and customs may call for; but it would be very ill-judged in us to follow their example in this instance." "I do not pretend that language is a science," he says in addition. "It is only an instrument for the attainment of science, but that time is not lost which is employed in providing tools for future operations."

Jefferson always conceived more than he could consummate. Back as far as 1779, he had tried to have chemistry made an independent branch at William and Mary. This was at a time when Buffon thought that chemistry was no more entitled to be called a science than cookery.

One of the branches which Jefferson thought the best fitted for a place in a university school for the people was what he called the Science of Government political economy, and the political history of England 
and the United States, and of Virginia, the Constitution of the United States, and the Federalist, etc. I am not sure, but I do not believe that the idea of establishing a school of the Science of Government in its several branches had then been broached by any one. At any rate, it is only of late years that such schools have been established in any degree of completeness at all, including even diplomacy and the history of diplomacy, in American universities. Of course, constitutional law and international law were very early taught to those, who proposed to pursue the legal profession, and in them is to be found much of the science of government. Some slight degree of proficiency in such science of political economy as then existed was, too, within the reach of the American student. Notwithstanding all of Jefferson's efforts, the University of Virginia has not to-day a separate school of the science of government. There was some talk three or four years ago about adding that school to the others, but I believe, for some reason, the project failed. It is the noblest of all studies, and the most universally useful in a free country. Whatsoever is done now in that line of study by the youth of our country - and especially at Columbia and at Johns Hopkins much good work has been done - it must be remembered, to Jefferson's eternal honor, that he proposed it nearly a hundred years ago; in fact, going back to his first proposal of it, fully that long.

All through the very many expressions occurring and recurring in his letters and public papers concerning education, is the idea that its chief object is to fit men for citizenship and statesmanship. No man ever 
realized more keenly than he the interplay between democratic institutions and education, the manner in which each requires and nourishes the other. It is not only true that free institutions cannot exist for long, when based upon doing the will of the ignorant, but it is also true that democratic institutions constitute the greatest encouragement to education. Education being necessary to its success, a successful democracy must provide it. The one, education, is the firm base; the other, democracy, is the beautiful super-structure. They are parts of one monument - a monument dedicated to the indefinite perfectibility of human institutions, and of the human race.

Jefferson, the theorist! And yet, as early as April, 1814, he had seized upon a great idea - still connecting education and citizenship - which has even yet been adopted in only four or five of the American States, my own, I am proud to say, being one of them.

In a letter written to De Onis, then Spanish Minister, he said, concerning the Constitution, which had been adopted by the liberal party in Spain:-

"There is one provision which will immortalize its inventors. It is that which, after a certain epoch, disfranchises every citizen who cannot read and write. This is new, and it is the fruitful germ of the improvement of everything good, and the correction of everything imperfect in the present constitution. This will give you an enlightened people, and an energetic public opinion which will control and enchain the aristocratic spirit of the government."

In every country where the aristocracy rules, it rules by the aid of an ignorant rabble, by military subjection, by purchase of votes, by intimidation about employment, by force of the rabble being somehow 
dependent upon it, or, by the force of a certain menial and master affinity - like that between the "nigger" and the "quality" - which ties the rabble to the aristocracy. D'Israeli had to some extent this idea of coöperation of the aristocracy and the rabble, in his mind, as have had some of the other so-called "Democratic Tories" in Great Britain. If you can cut off that ignorant, illiterate rabble by confining the suffrage to those at least, who are sufficiently enlightened to read and write, you have to a large extent limited the scope of aristocratic influence.

While we teach that men must prepare themselves for many things, we leave them to imagine that they are natural-born graduates in the science of government. Never fear that in the long run, democracy will not find its own errors, and will not correct them. But also never hope that in the meantime there will not be much of error, much of wrong, and some oppression.

My own impression is that an educational qualification for the suffrage would go far to remove the evil of bad government, and that teaching every man something of the science of government, and at least so much to the informed as involves the proposition that he is a poor citizen, who does not carry his information to his primaries and to the elections, would go further. At any rate, it is plain that every species of information and of science has been more rapidly advanced, than the science of government itself.

This subject was a sort of mania with Jefferson. Numbers of young men in Virginia were writing to him all the time to know what books to read, writing to him as a sort of tutor. Many of them moved into 


\section{PERMANENT INFLUENCE OF JEFFERSON}

Charlottesville, even before the University was opened, to get the benefit of his advice and library. He wrote to Kosciuszko concerning them in this language:-

"In advising the course of their reading, I endeavor to keep their attention fixed on the main objects of all science, the freedom and happiness of men. So that, coming to bear a share in the councils and government of their country, they will keep ever in view the sole objects of all legitimate government."

He never had the happiness of reading Tennyson, but he understood fully the theory and hope of men rising "on stepping-stones of their dead selves to higher things," and, although he never expressed it in that way, he would have been charmed with Tennyson's expression of the idea, that the final and highest goal and hope for all is "in the Parliament of man, the Federation of the world," and that man's nearest approach to perfectibility will be when among an informed people "the common sense of most shall hold a fretful realm in awe." "The common sense of most" is an expression that would have tickled his very heart, and I sometimes wonder why he never thought of it. I sometimes wonder, too, how much, if anything, of the idealist poet's thoughts were due to Thomas Jefferson. Consciously, I imagine, very little - unconsciously, and by world-kinship-infiltration, I suspect, a good deal. However that may be, there is much in common between what may be called the political and social philosophy of Locksley Hall and the ideas of Jefferson.

One of the curious reasons that Jefferson gives in recommending especially the study of history is that it "will enable them [that is, the people] to know 
ambition under every guise it may assume; and knowing it, to defeat its views.'

Ambitious and self-seeking men are such chameleons, and succeeding periods and conditions differ so much from those that have gone before, that it would be curious to examine how far familiarity with the methods of the old enemies of liberty would teach the people the designs of the new.

It is pathetic to note the broad scope of Jefferson's ideas, as in the letter to Peter Carr, during the Revolution, when compared with what the Legislature and the people of the State of Virginia could be prevailed upon, or were able, actually to do. He speaks of teaching not only the Science of Government, to which $I$ have referred, but agriculture, horticulture, veterinary science, and electricity, about which almost nothing was known in his day, and meteorology, a science of which it may be said that it is not yet full born, and, finally, galvanism and magnetism, concerning which the same statement may even yet be made. Even at that early date, he suggested a scheme for night schools, where lectures should be given to those, whose daily occupations did not permit them to use daylight time.' I have no knowledge whether any of the founders of any of these most useful institutions ever got inspiration from him, but I know that he preceded them all in America by from a quarter to a half a century, and that if they had read him, it would have been a helpful and sympathetic reading.

After much reading of Jefferson, I cannot escape the idea that he frequently wrote with the conviction that every word he put on paper would some day come to 
be read, not in Virginia alone, but far outside of her limits. I cannot account for many utterances, except upon "the sowing the seed by the wayside" theory. A thought with him was a seed to grow, a germ to infect, "a little leaven to leaven the whole lump," after the fermentation of its kind.

Jefferson attached a school of agriculture to his scheme of the University, and explained how many of the things to be taught in the other schools, like chemistry, and botany, and zoölogy, etc., would naturally interlink themselves with the study of agriculture; like chemistry, for example, becoming agricultural chemistry, etc. Most of our States, upon receiving Federal aid for agricultural schools, have founded separate institutions, duplicating much of the work done at the State universities, and duplicating, to a great degree, the expense. A school of agriculture connected with each State university, and a plan for a degree in agriculture, to be attained as a result of proficiency in all the studies in the agricultural school proper, plus a proficiency in several other cognate schools, would have effected the purpose in view much more cheaply and much more efficiently, provided only the State university would not have required of the boy desiring to study agriculture, that he pass a senseless examination in subjects a knowledge of which is not necessary to the mastery of scientific agriculture.

It was peculiarly fit that in Jefferson's memory a school of agriculture should have been attached to the University of Virginia, and, yet, after an ineffectual attempt, which failed for what reasons I know not (but chiefly, I take it, because of the contempt felt by 
the votaries of higher classicism for so plebeian a pursuit), a separate college of agriculture was founded at Blacksburg, Virginia.

Those who understand Jefferson's peculiarly interesting character can smile with pleasure, when they reflect how pleased he would have been at the perusal of the endless number of Farmers' Bulletins, which proceed from the Department of Agriculture at Washington, and from the various agricultural colleges of the country. He would have been superlatively absorbed in some of Dr. Wiley's interesting work, and in his still more interesting narration of it, and his optimistic and sanguine temperament, running ahead of the time to the end, would have seen in Willis Moore's meteorological reports a period when the agriculturalist, "forewarned by science," would no longer hold his fortune at the sport of winds and frosts.

In the "back to the farm" movement, Jefferson would have been in the front rank. He always thought that farming was the natural, and the noblest industrial pursuit in which men could engage. He speaks of it in a letter to David Williams, dated November 4, 1803, as the one which is "first in utility" and "ought to be first in respect." He thought that:-

"The same artificial means which have been used to produce a competition in learning, may be equally successful in restoring agriculture to its primary dignity in the eyes of men. It is a science of the very first order. It counts among its handmaids the most respectable sciences; such as Chemistry, Natural Philosophy, Mechanics, Mathematics generally, Natural History, Botany. In every college and university a professorship of agriculture, and the class of its students, might be honored as the first. Young men choosing their academical education with this, as the crown of all 


\section{PERMANENT INFLUENCE OF EJFFERSON}

other sciences, fascinated with its solid charms, and at a time when they are to choose an occupation, instead of crowding the other classes, would return to the farms of their fathers, their own, or those of others, and replenish and invigorate a calling now languishing," etc.

True then, every word of it. True yet. The disease called high cost of living, and by many other names, is here diagnosed, and a partial remedy is eloquently suggested. In addition to that, it sounds, does it not, a good deal like what we are pleased to call "modern scientific agriculture"? It is as far removed as possible from the notion that a boy that is fit for anything else ought not to go to farming, and still further removed from the cavalier-like contempt with which college fledgelings view the great primary art. The truth is, that it requires very much more brains and very much more information to be a really successful and up-todate farmer, than it does to make an excellent lawyer, physician, Senator, or college professor - besides contributing more to human comfort and freedom. It is one of the occupations that you cannot pursue to highest point of success without possessing a sort of encyclopedic information, coupled with initiative and decision, for the problem is never the same for any two years.

But enough of what is perhaps a hobby.

Speaking of English - the noblest of languages and the importance of its study, these are his words: "A language already fraught with all the eminent science of our parent country, the future vehicle of whatever we may ourselves achieve, and destined to occupy so much space on the globe, claims distinguished attention in American education." He might 
have expressed a just pride that before he retired from office his policies had resulted in our language occupying a yet more broadly extended "space on the Globe."

When Jefferson was a boy his father had told him that the training of the hand must go step by step with that of the mind. In fact, his father, being a very large and powerful man, held the opinion that really great minds could not exist outside of strong bodies. Jefferson therefore pointed out that a hall for physical training, with the proper apparatus, ought to be attached to the University. Again the consummation fell short of his conceptions. The Virginia Legislature regarded that, I suppose, as "one of Jefferson's pets." At any rate, the University did not have a gymnasium until a few years ago, when Mr. Fayerweather donated the money for its erection and equipment.

In a letter to Peter Carr, which Jefferson wrote on September 7, 1814, he thus outlines another scheme for physical culture and national defense, which even to this day has not gone into operation and which might well be adopted at his and all State universities: "Through the whole collegiate course, at the hours of recreation on certain days, all of the students should be taught the manual exercise [meaning the manual of arms], military evolutions, and manœuvres, and should be under a standing organization, with proper officers to train and command them." It seems curious that Jefferson should seemingly have forgotten here his own cherished principle of leaving the choice of study always open to the student. However, his idea might be well applied, with this modification, that those only who choose to do so shall attend the school of military 


\section{PERMANENT INFLUENCE OF JEFFERSON}

science and practice. Thus the members of the student military organization would be volunteers. It would furnish the United States, by the way, with a very good and not a small army - highly trained, because composed of especially intelligent men - without a dollar of public expense, except the amount of money necessary for each State to employ the three professors of tactics and strategy and military history - even these, as well as the drill master, could be detailed from the Regular Army. The other branches - mathematics, engineering, etc. - would interlink from the other schools already existing in each university.

The heart of a university is its teaching faculty, and its library. Jefferson's University was early provided with a very useful library, from which, however, he excluded novels, and, from the beginning, his own library, which was probably the largest and best selected private collection then in America, was at the service of its students.

His professors were gotten, for the most part, from abroad. They were all men of the highest ability in their respective lines of work.

But even teachers cannot make an institution of learning great unless the teachers and the teaching are free and untrammelled. With this idea in his mind, Mr. Jefferson, in a letter to Mr. Roscoe, dated December 7, 1820, says:-

"This institution will be based on the illimitable freedom of the human mind. For here we are not afraid to follow the truth wherever it may lead, nor to tolerate any error, so long as reason is left free to combat it." 
His professors went through the experience, that every man and woman did, who were brought into close personal contact with Jefferson, unless there was some political or religious reason to make it almost impossible. They fell in love with him. It is interesting, and, indeed, affecting, to read what they wrote about him - Dunglison, Tucker, and all of them.

It is perfectly wonderful that the man should have succeeded in erecting the beautiful buildings, each a type of classic architecture - himself being the architect and draftsman - in importing the professors, and in putting the institution into operation, considering where he was, by what confronted, and what limited means he had at his disposal. The poorer men of Virginia were apt to say, "well, that will never do my boy any good. I cannot afford to board him there." The rich planter was wont to say that he had money enough to send his own boys to college and he did not care about being taxed to send other people's boys thither. Of this last class, who were not as numerous as the former, but had much more influence with the Legislature, Jefferson, on January 14, 1818, in writing to Cabell, said - and I think said beautifully:-

"And will the wealthy individual have no retribution, and what will this be? 1. The peopling of his neighborhood with honest, useful, and enlightened citizens, understanding their own rights and firm in their perpetuation. 2. When their own descendants become poor, which they generally do in three generations, (no law of primogeniture now perpetuating wealth in the same families) their children will be educated by the then rich, to his descendants, when become poor, thus will be given a chance of rising again. This is a solid consideration and should go home to the bosom of every parent. This will be seed sown in fertile ground. It is a 


\section{PERMANENT INFLUENCE OF JEFFERSON}

provision for his family looking to distant times, and far in duration beyond that he has now in hand for them. Let every man count backward in his own family, and see how many generations he can go before he comes to the ancestor who made the fortune he now holds. Most of us will be stopped at the first generation, many at the second, few will reach the third, and not one in the State can go beyond the fifth."

The finest citizenship in the world in the days of Washington and Jefferson was, and in our own day is, that of Virginia. English sturdiness and sure-footedness are combined with American vivacity and initiative. Its greatness especially shines out in loyalty and courage and truth, and simplicity of living - the cardinal virtues; but it was not then and it is not now peculiarly susceptible to appeals to make pecuniary sacrifices to be recompensed by remote rewards, especially if these rewards are of an educational character. But the patient, sweet-tempered old philosopher won measurable victory over all difficulties, and was ready when his time came to say nunc dimittis.

When La Fayette visited the University and Monticello in 1825, at the grand banquet which was given to him Jefferson attended, and in response to a toast in his own honor, being too feeble to rise and respond, handed to a friend to read a paper upon which the following words were written:-

"My friends, I am old, long in the disuse of making speeches, and without voice to utter them. In this feeble state, the exhausted powers of life leave little within my competence for your service. If, with the aid of my younger and abler coadjutors, I can still contribute anything to advance the institution within whose walls we are mingling manifestations to this our guest, it will be, as it ever has been, cheerfully and zealously bestowed. And could I live to 
see it once enjoy the patronage and cherishment of our public authorities with undivided voice, I should die without a doubt of the future fortunes of my native State, and in the consoling contemplation of the happy influence of this institution on its character, its virtue, its prosperity, and safety."

He never lived to see it enjoy "with undivided voice the patronage and cherishment" of Virginia's "public authorities," nor has any one yet lived thus long. Virginia has been, upon the whole, niggardly, not generous. It looks now, as if she would leave the first completely established State university in the world behind those that have been established elsewhere on the plan of its founder. The people of the new States in the West have adopted Jefferson's state university idea, and they have been much more generous, and less divided, in their support. Many of the Western universities surpass the parent institution in wealth, appliances, numbers in the faculty, comprehensive scope of teaching, and, especially, with irony of fate, in those very practical applied sciences, that Jefferson's mind was so peculiarly bent upon fostering. But his influence has been none the less great and permanent, not only in the Western States, where his idea was taken up "with undivided voice," but in his own State, and the institution which he founded has given tone and character, in a notable way, not only to Virginia, but to the entire South. Its work has been thorough, even where its scope has not been comprehensive, and the esprit $d u$ corps has constituted one of the most precious things upon the American continent-diffusing a spirit of honor, freedom, and love of truth. It is to-day undoubtedly, in its spirit and in its practices, the least 


\section{PERMANENT INFLUENCE OF JEFFERSON}

plutocratic and perhaps the most democratic institution in the East. Its students do not know, because they do not inquire, nor care to know, whether a student is poor or rich. They do sometimes know whether he comes from a good or a bad family.

Tucker says that in consequence of a riotous tumult in which one of Jefferson's nephews was concerned, the laws of freedom at the University had to be somewhat altered. Perhaps so in theory, and perhaps so even in practice in his time, but in my day, in practice at any rate, there were only two rules: first, the rule which guides gentlemen in their intercourse with one another; and secondly, the rule which ought to guide all citizens - obedience to the laws of the State and of the United States. There was no such thing as a public expulsion, though sometimes young men would quietly go home, and the supposition was that the Chairman of the Faculty had called for them, and, in a private conversation, had admonished them that they were doing no good for themselves or anybody else, and that perhaps it would be better for them to "seek some other field of usefulness." Whenever this took place, of course it meant that they did go; but Jefferson's idea of not putting a stain upon a mere youth, that might hamper him all through life, was observed in my day there. There was a rule that you must attend lectures; that is, that you must not "cut" over so many lectures in a month, unless your absence was due to sickness, and it was pretty well known that transcending this rule might lead to the private admonition. Being once in the class room and being interrogated upon the subject matter of the last lecture, any student could reply 
"Not prepared," and there was, strange to say, no limit upon the number of times that he could reply "Not prepared." There was a reason for it: he had to pass his "Intermediates" and "Finals" anyhow they were the tests.

In connection with Jefferson and the University of Virginia, Schouler, in his "Life of Jefferson," says:-

"The first Rector of the University of Virginia lived long enough to see the institution opened in the Spring of 1825 , with a fair roll of students for matriculation and a corps of able professors, most of whom he imported from Europe, recognizing that in the world of letters a young Republic must not be self-sufficient. Vicissitudes shared by Virginia herself have kept this institution, perhaps, from making its impression felt throughout the Union; but the oldest and richest of America's institutions have, in later times, enlarged, one after another, their spheres of activities upon a similar model. All the strong ideas which Jefferson's university put in force for the first time upon American soil, remain to this day as the founder fixed them - the distinct schools in which one may specialize his knowledge; the substitution of electives for the routine of a curriculum; the honour system of discipline among students, which sets them to influencing one another and makes a law of liberty; and finally, an even balance between all religious and political sects and parties. In matters of the higher education Jefferson, as a close student of comparative systems and an adapter to the American age, was much farther in advance of his times than in politics; and hence his fame in that respect has come less rapidly, but it will come at last."

Hamilton W. Mabie, in an article on "The University of Virginia," says:-

"It fulfilled Jefferson's noble conception of the place of a university in a democratic society. It was our first real university. It was literally Jefferson's creation. It is the most democratic of American colleges in its organization." 


\section{PERMANENT INFLUENCE OF JEFFERSON}

He adds that it was "the first college in this country to adopt a general architectural scheme and to preserve it intact." George F. Mellen, in an article entitled "Thomas Jefferson and Higher Education," New England Magazine, n. s., vol. 26, 1902, says: "He affected vitally educational ideals and changed radically some of the current educational practices." He "introduced a distinct chair of modern languages, . . . and became the first champion of modern language studies in an American college curriculum." George Ticknor visited and sojourned with Jefferson at Monticello in 1815, previous to his trip to Germany for study. Mellen says their intimacy "bore fruit in broadening and liberalizing work at Harvard," where Ticknor became professor of French and Spanish literature.

That Jefferson interested himself in public libraries as schools for adults - and therefore indispensable educational auxiliaries - was demonstrated in his letters. In 1809 he wrote to John Wyche, who had informed him in a recent letter of the establishment of a library society:

"I always hear with pleasure of institutions for the promotion of knowledge among my countrymen. The people of every country are the only safe guardians of their own rights, and are the only instruments which can be used for their destruction. And certainly they would never consent to be so used, were they not deceived. To avoid this, they should be instructed to a certain degree. I have often thought that nothing would do more good at small expense than the establishment of a small circulating library in every county, to consist of a few well-chosen books, to be lent to the people of the county, under such regulations as would secure their safe return in due time. These should be such as would give them a general view of other history, and a particular view of that 
of their own country, a tolerable knowledge of geography, the elements of natural philosophy, of agriculture, and mechanics."

Of course, this is a vastly different scheme from those immense collections in large cities, in great and expensive buildings, of all sorts of books, whose benefits may be great, but are not diffused throughout those neighborhoods where they are most needed. It is doubtful, if a great free library in a great city, the donation of some generous man, produces results commensurate with the expense. In the first place, there are apt to be several free libraries and a large number of circulating libraries already in existence. In the second place, for those who are not perfectly indigent books are to be bought, except expensive reference books, for a very little. As a part of the "back to the farm" movement, there ought to be a free circulating library in every rural neighborhood, or else a free public library. It could be made a part of the school teacher's business to carry the key, to give out and take in and keep account of the books. To save the public from any expense at all - except the very slight one of wear and tear by use - a deposit might be asked, recoverable upon the return of the book.

In connection with Jefferson's other educational work, he was a member of the Virginia State Literary Fund Board. Virginia not being prepared for compulsory education, he suggested the idea of holding over the parent the penalty of the disfranchisement of those of his children who could not read or write, adding: "Society has certainly the right to disavow him, whom it offers, and is not permitted to qualify 
for, the duties of a citizen. If we do not force instruction, let us at least strengthen the motive to receive it when offered."

\section{The following letter to Cabell I think is one of the} noblest ever penned, in its fortitude and optimism, and in its faith in the youth of the future:-

"When I retired from the administration of public affairs, I thought I saw some evidence that I retired with a good degree of public favour, and that my conduct in office had been considered, by the one party at least, with approbation, and with acquiescence by the other. But the attempt in which I have embarked so earnestly, to procure an improvement in the normal condition of my native state, although, perhaps, in other states it may have strengthened good dispositions, it has assuredly weakened them within our own. The attempt ran foul of so many local interests, of so many personal views, and so much ignorance, and I have been considered, as so particularly its promoter, that I see evidently a great change of sentiment towards myself. I cannot doubt its having dissatisfied a respectable minority, if not a majority of the House of Delegates. I feel it deeply and very discouragingly. Yet I shall not give way. I have ever found in my progress through life, that, acting for the public, if we do always what is right, the approbation denied in the beginning will surely follow us in the end. It is from posterity we are to expect remuneration for the sacrifices we are making for their service - of time, quiet, and good will, and I fear not the appeal. The multitude of fine young men whom we shall redeem from ignorance, and who will feel that they owe to us the elevation of mind, of character, and station they will be able to attain from the result of our efforts, will insure their remembering us with gratitude, we will not then be weary in well doing. Usque ad aras, amicus tuus."

The fact that Jefferson selected college-bred men for his Cabinet has been cited to prove that he was a hypocrite in his professions of democracy! It merely proves malice on the part of him making the charge and that 
Jefferson was not a demagogue. His action was absolutely consistent with the theory from which he never departed, that information and education are necessary for government, especially in those who do the actual governing.

The policy of giving to the States for educational purposes the sixteenth sections of the public lands, while the Government of the United States retains control of the balance, had its beginning under Jefferson's administration, at the time of the admission of Ohio as a State. There was also given to that State five per cent of the sales of public lands. The consecration of the sixteenth sections to "the better diffusion of information" in Ohio was imitated afterwards in all cases upon the admission of new States, save in that of Texas, which being first an independent republic, reserved, with our consent, all her public lands.

Nothing in our whole history has had a more permanently beneficial effect upon our institutions - political, social and educational. One cannot doubt that it was at President Jefferson's suggestion that Gallatin, his Secretary of the Treasury, having at that time the Land Office in his Department, made the recommendations to Congress.

As President of the United States, he signed many bills in which he approved appropriating public lands not only for common schools, but for academies and colleges. His conceptions were stupendous. They are sometimes humorous or pathetic-depending on your mood - when contrasted with his limited means of embodying them. For example, his scheme of transferring the whole University of Geneva to Rich- 
mond, Virginia - a scheme which might have been perfected, by the way, but for the fact that General Washington pronounced the scheme impracticable. Washington was one of the few men, whose opinions sometimes controlled, and always influenced Jefferson.

Jefferson, while President, signed a bill providing that in the territory south of the Tennessee line (constituting the present States of Mississippi and Alabama) the sixteenth section of every township should be dedicated to the support of public schools, and in the Territory of Mississippi thirty-six sections of land were given for the use of a college - which, by the way was subsequently called "Jefferson College" in compliment to the President. I am sorry to say that this munificent foundation was frittered away. After the Louisiana Territory had been acquired and opened for settlement, Jefferson signed the bill of April 21, 1806, which not only reserved the sixteenth section of every township, but devoted an additional township for the support of "a seminary of learning."

He was an economist, but when it came to giving away land for school purposes, he was as much of a spendthrift, as he who was most of one. He was a strict constructionist, but it does not seem to have occurred to him that there could be any doubt of the right of the Federal Government to give away its own lands in advancement of the intelligence of its own citizens. In this, it was not acting so much in the capacity of a government, as in that of a land-owner, Congress being expressly empowered by the Constitution to "dispose of the territory and other property of the United States." The dear old optimist had no 
distrust of the future, as long as the destinies of the country were hung to his "two hooks," popular education, and local self-government.

You will remember that Jefferson once suggested amending the Constitution, so as to authorize the Federal Government to coöperate with the States in educational work. I think it may perhaps be said with truth - though I have not given sufficient detailed research to make me assured of the accuracy of the comparison - that under no single administration of the Federal Government was there ever so much done by the Government, with a view to helping the States establish and maintain education, as under his administration.

The first Republican Congress, with the incoming of Jefferson, introduced a new custom which has had an abiding and permanent educational effect upon the people. Up to that time newspaper reporters were admitted and expelled at the will of the Speaker, and even while present, were not considered privileged to comment upon the proceedings. One Speaker expelled two for reporting speeches. Over in the Senate they could sit in the gallery with the other spectators, if they chose. The Republicans now gave reporters desks on the floor, and ever since then that has been the custom. This has two important effects: first, it acts as a restraint and check upon the Congressmen in both Houses; second, it educates the people in practical governmental science.

On December 10, 1821, Hugh Nelson, a Representative from Virginia, presented a petition signed by Jefferson for the "Rector and Visitors of the University 
of Virginia," praying that "the aid and patronage of Congress may be extended to the cause of science and literature generally throughout the United States by an exemption from duties of all books and other articles generally used in acquiring information." This duty was fifteen per cent. In the petition, well worth your perusal, occurs this phrase: "To obstruct the acquisition of books from abroad, as an encouragement of the progress of literature at home, is burying the fountain to increase the flow of its waters."

An adverse report from the Senate Finance Committee calls books "foreign luxuries" - fit subjects, therefore, for taxation, and objects "to singling out this important branch of industry" and "stripping it of all protection" and "leaving it to struggle with powerful competitors." How familiar these stock phrases of beneficiaries of law-conferred special privileges! Also in the adverse report, foreign books are feared "as a means of foreign influence from which our youths may imbibe sentiments, dangerous to our liberties."

For three years the movement was laid aside. Then, in 1824, Jared Sparks took it up again in the North American Review, and Jefferson wrote a letter to encourage him in the good and wise work. It was published with effect, and in the Tariff Act of 1824, the taxes on books "printed before 1775" and on all books in foreign languages, except Latin and Greek, were reduced. Printed before 1775 ! We didn't want any late information! Too dangerous a luxury! Dangerous to the publishers. Thus Congress refused "to wipe this stain from our legislation," as Jefferson 
stigmatizes it in his letter to Sparks, "and if possible obliterate it from the mind of man."

In conclusion: Well warranted, indeed then, were these words of the lovable "friend of man," written in his extreme old age, not long before "the night came, when no man could work," and standing as a prophecy and a promise to be literally fulfilled up to the very day but one before his death:-

"A system of general instruction which shall reach every dedescription of our citizens from the highest to the poorest, as it was the earliest, so it will be the latest, of all the public concerns in which I shall permit myself to take an interest."

Verily; again the words recur:-

"He was stigmatized as a dreamer, but his dreams came true." 


\section{BIBLIOGRAPHY}

Adams, Henry. History of the United States of America. New York, Scribner, 1891-98. $9 \mathrm{v}$.

Adams, Herbert Baxter. Thomas Jefferson and the University of

Virginia. Washington, Bureau of Education, 1888

ADAMS, JонN. Works, with a life of the author, notes and illustrations . . . by Charles Francis Adams. Boston, Little, 1850-56. $10 \mathrm{v}$. Adams, JoHn. Defence of the constitutions of government of the United States. (In Works, v. 6)

Adams, John. Discourses of Davila. (In Works, v. 6)

Ames, Fisher. Works; with a selection from his speeches and correspondence; edited by Seth Ames. Boston, Little, 1854. 2 v.

Bancroft, George. History of the United States. Author's last revision. New York, Appleton, 1883-85. 6 v.

Bodteld, Lewis Henry. Thomas Jefferson, the man of letters. Chicago, Privately printed, 1891

Bryce, James. The American commonwealth. 3rd edition. New York, Macmillan, 1893-95. 2 v.

BURK, John [DaLY]. History of Virginia from its first settlement to the present time. Vol. 1-3. Petersburg, the Author, 1804-5

Continued by S. Jones and L. H. Gerardin. Vol. 4. Petersburg, Proprietors, 1816

Carter, James Coolidge. The University of Virginia; Jefferson its father and his political philosophy; an address delivered upon the occasion of the dedication of the new buildings of the University, June 14, 1898. [Charlottesville] The University, 1898

Cook, Theodore Andrea. The original intention of the Monroe doctrine. Fortnightly Review, 1898. 70: 357-68

Cooke, John Esten. Virginia; a history for the people. With a supplementary chapter by W. G. Brown. (American commonwealths) Boston, Houghton, 1903

Curtis, Wiluiam Eleroy. The true Thomas Jefferson. Philadelphia, Lippincott, 1901

Dickinson, JoHn. Political writings. Wilmington, Bonsal, 1801. 2 v Dickinson, John. The declaration by the representatives of the United Colonies of North-America, . . . setting forth the causes and necessity of their taking up arms. July 6th, 1775. (In his Political writings. 1801, v. 2) 
Emancipation of Spanish America. Edinburgh Review, 1808. 13: 277-311

Federalist, The; a collection of essays written in support of the Constitution, reprinted from the original text of Alexander Hamilton, John Jay and James Madison; edited by H. C. Lodge. New York, Putnam, 1902

Fiske, JoHn. The American Revolution. Boston, Houghton, 1899. 2 v. FIske, JoHN. Thomas Jefferson the conservative reformer. (In his Essays historical and literary. New York, Macmillan, 1902, vol. 1)

Ford, PaUl Leicester. The French Revolution and Jefferson. The Nation, 1895. 61: 61

Ford, Paul Leicester. Thomas Jefferson. Boston, Elson, 1904

Foster, John Watson. A century of American diplomacy. New York, Houghton, 1900

Gardener, Helen Hamilton. An unofficial patriot. Boston, Arena Pub. Co., 1894

Gibis, George. Memoirs of the administrations of Washington and John Adams; edited from the papers of Oliver Wolcott. New York [Van Norden, printer] 1846. 2 v.

Girardin, L. H. See BUrk, John Daly, above

Grigsby, Hugh Blair. The Virginia Convention of 1776. A discourse delivered before the Virginia Alpha of the Phi Beta Kappa Society, in the chapel of William and Mary College . . . July 3, 1855. Richmond, Randolph, 1855

Hamilton, Alexander. [Speech in the Constitutional Convention, June 18, 1787.] (In Madison, James. Papers. 1840. vol. 2, p. 878-92)

Hamilton, Alexander. Works; comprising his correspondence, and his political and official writings. . . Edited by John C. Hamilton. New York, Trow, printer, 1850-51. $7 \mathrm{v}$.

Hammlon, John Chorch. Life of Alexander Hamilton. A history of the Republic .... as traced in his writings and in those of his contemporaries. Boston, Houghton, 1879. $7 \mathrm{v}$.

Hart, Albert Bushnell. American history told by contemporaries. New York, Macmillan, 1901. Vol. 3: National expansion, 17831845, p. $344-433$

Hart, Albert Bushnell. The formation of the Union. 1750-1829.

(Epochs of American history) New York, Longmans, 1910

Hazen, Charlegs Downer. Jefferson in France. (In his Contemporary American opinion of the French Revolution. Baltimore, Johns Hopkins Univ., 1897) 
Ingersoll, Charles Jared. The duty on foreign books. North American, 1824. 18: 163-68

JAY, JoHN. Correspondence and public papers, 1763-1826; edited by

H. P. Johnston. New York, Putnam, 1890-93. 4 v.

Jefrerson, Thomas. Writings; collected and edited by Paul Leicester

Ford. 1760-1826. New York, Putnam, 1892-99. $10 \mathrm{v}$.

Jefrerson, Thomas. The Anas. (In Writings. Vol. 1, p. 154-339)

Jefrerson, Thomas. Autobiography. (In Writings. Vol. 1, p. 1-

153)

Jefrerson, Thomas. Communication to the American Commissioners

at Madrid, June 30, 1793. (In Writings. Vol. 6, p. 330-38)

Jefrerson, Thomas. The Declaration of independence. (In Writings.

Vol. 2, p. 42-58. facsim.)

Jefrerson, Thomas. Declaration on taking up arms. (In Writings.

Vol. 1, p. 462-76)

Jemperson, Thomas. Draft of Report on Lord North's motion. (In Writings. Vol. 1, p. 476-82)

Jefrerson, Tromas. The Jefferson Bible. Philadelphia, McKay, 1908

Jefrerson, Thомas. Manual of parliamentary practice. (In U. S.

Congress-House of Representatives. Constitution, Jefferson's manual, and Rules of the House. . . 1912)

Jefrerson, Thomas. Notes on the state of Virginia. (In Writings.

Vol. 3, p. 68-295)

Jefrerson, Thomas. Report of the revisors. June 18th, 1779. (In

Writings. Vol. 2, p. 195-239)

Jefrerson, Thomas. A Summary view of the rights of British America. . . (In Writings. Vol. 1, p. 421-47)

Jefferson's Memoirs and correspondence. Edinburgh Review, 1830. 51: 496-528

Kean, Robert Garitc Hill. Thomas Jefferson as a legislator. [Richmond] 1887

From Virginia Law Journal, 11: 705-24

Lincoln, Abraham. Complete works; edited by John G. Nicolay and John Hay. . . New and enlarged edition. New York; Tandy, [c 1905] 12 v.

Letter on Jefferson's birthday. $\nabla .5$, p. 124-26

Lodge, Henry Cabot (editor). History of the United States, by J. W. Garner and H. C. Lodge. (History of nations, v. 23-24) Philadelphia, Morris, 1906

Mabie, Hamilton Wright. Some famous schools: The University of Virginia. Outlook, August 4, 1900. 65: 785 
MAdison, JaMes. Papers; being his correspondence and reports of debates; [edited] by Henry D. Gilpin. Washington, Langtree, 1840. $3 \mathrm{v}$.

Marshall, John. The Life of George Washington. . . 2nd edition. Philadelphia, Crissy, 1850. $2 \mathrm{v}$.

Mellen, George Frederick. Thomas Jefferson and higher education. New England Magazine, 1902, n. s. 26:607-16

Merriam, Charles Edward. A history of American political theories. New York, Macmillan, 1903

Merwin, Henry Childs. Thomas Jefferson. (Riverside biog. series.) Boston, Houghton [1901]

Morris, Goovernevr. Diary and letters; edited by Anne Cary Morris. New York, Scribner, 1888. 2 v.

Morse, John Torrex, Jr. Thomas Jefferson. (American statesmen)

Boston, Houghton, 1883

New England Magazine. [Editorials on Thomas Jefferson.] 19001. n. s. $23: 228-40$

OTIS, JAMES. The Rights of the British colonies asserted and proved. Boston, Edes, 1764

Parmelee, Mary Platt. Jefferson and his political philosophy. Arena, 1897. 18: 505-16

Parton, James. Jefferson a reformer of Old Virginia. Atlantic Monthly, 1872. 30: 32-49

Parton, James. Jefferson's return from France in 1789. Atlantic Monthly, 1872. 30: 547-65

Parton, James. Meeting of Jefferson and Hamilton. Atlantic Monthly, 1872. 30: 704-19

Poweld, Edward Payson. Jefferson and Hamilton in our education. New England Magazine, 1896. n. s. 14: 699-706

Poweld, Edward Payson. A study of Thomas Jefferson. The Arena, 1891. 3: 712-23

QUincy, Josiar. Speeches delivered in the Congress of the United States, 1805-13; edited by Edmund Quincy. Boston, Little, 1874 Randall, - . Thomas Jefferson as a lawyer. Columbia Jurist, 1886. 2: $479-80$

From the Legal Adviser, 7: 223

Randali, Henry Stephens. The Life of Thomas Jefferson. New York, Derby, 1858. 3 v.

Russell, John, 1st earl. Life and times of Charles James Fox. London, 1859-66. $3 \mathrm{v}$.

Sabine, Lorenzo. Biographical sketches of loyalists of the American Revolution. Boston, Little, 1864. 2 v. 
Sage, Bernard Janin. A republic of republics: A retrospect of our century of federal liberty. . . 3rd edition. Philadelphia, Harding, 1878

Sainte-Beuve, Charles Augustin. Premiers lundis. Tome 2. Paris, Lévy, 1874

Schouler, James. Thomas Jefferson. (Makers of America) New York, Dodd, 1893

Tourgee, Albion Winegar. A fool's errand. New York, Fords, 1902

Tucker, George. The life of Thomas Jefferson ... Philadelphia, Carey, 1837. 2 v.

Tyler, Moses Coit. The literary history of the American Revolution. New York, Putnam, 1897-98. 2 v.

Vest, George Graham. Thomas Jefferson. An address at Columbia, Missouri, June 4th, 1885. St. Louis, Buxtom, 1885

Walker, Francis Amasa. The making of the nation. 1783-1817. (American history series) New York, Scribner, 1899

Washington, George. Writings; collected and edited by Worthington Chauncey Ford. New York, Putnam, 1889-93. 14 v. Watson, Thomas Edward. Life and times of Thomas Jefferson. New York, Appleton, 1903

Webster, Daniel. Works. Boston, Little, 1851. 6 v.

Webster, Sinnex. Two treaties of Paris and the Supreme Court. New York, Harper, 1901

White, ANdrew Dickson. Jefferson and slavery. Atlantic Monthly, April, 1862. 9: 29-40

Winship, Albert Edward, and Robert W. Wallace. The Louisiana purchase as it was and as it is. Chicago, Flanagan [1903]

WitT, Cornélis Henri DE. Thomas Jefferson: Étude historique sur la démocratie américaine. Paris, 1861

Witt, CoRnelis Henri DE. Jefferson and the American democracy; an historical study; translated by R. S. H. Church. London, Longmans, 1862 


\section{INDEX}

Academy of science, A central, to control men, 53

Act for freedom of religion printed in Paris, 265

Adams, Henry, on rejection of treaty effected by Monroe, 133; on Jefferson's aspirations, 200-1

Adams, John, a founder, 1; error of, about the sentiment for independence, 29; inaccurate as to Declaration of Independence, 3031,40 ; colossus of debate, 31,42 ; member of committee to prepare Declaration, 33 ; to Pickering, on the Declaration, 41; wrote Report of Committee on Rights and Grievances, 42-43; failed to see ultimate issue of French Revolution, 59 ; contempt of, for common folks, 61; in France, 107; "Discourses of Davila," 143-44; a reactionary, 144; conversation with Hamilton on the British Constitution, 156-57; defeated Jefferson by three votes, 169-70; secured peace with France, 173-74; hated by Federalists, 174; his greatest of services, 180; heterodoxy of, 245-46 Adams, Samuel, at Boston tea-party, 9 ; and committees of correspondence, 9

Agriculture, A school of, planned, 289, 290-91

Albemarle County, Instructions of, 12-13; Committee of Safety in, 20, 21; British prisoners in, 109-10

Alien and sedition laws passed, 145; unexpected results of, 171 ; power of President under alien law, 172; Jefferson's antagonism to, 172 ; and Know-Nothing movement, 172

Allegiance, The doctrine of indefeasible, 16 ; first denial of, 68,91 America, the fad in France, 107 American colonies, The, expatriated themselves, 16
American Commissioners at Madrid, Jefferson's communication to the, 124-25

American experience, 6; our institutions the product of, 38

American history, A suppressed chapter of, 143, 148, 194

American nations, An American policy for all, 134, 136

American people, The, based their claims upon natural rights of man, 46

American political theory, Jefferson's the, 54

American products in France, 107-8

American reign of terror, 175

American Revolution, Back to the principles of the, 141, 183

Americanism, Exponents of, 100

Ames, Fisher, Letters of, 155; the American people like free negroes, 155 ; on use for an army, 180

Anarchy, Seeming state of, 12

Angles and Saxons, The, expatriated themselves, 16

Apollo Room in Raleigh Tavern at Williamsburg, Meetings in, 10, 11

Applied sciences, at University of Virginia, 282

Apportionment for representation, 240

Appropriations in lump sums, 237

Aristocracy and clergy, Jefferson's hatred of, learned in France, 57-58; eradication of, 85 ; and the rabble, 286-87

Aristocracy of Colonial Virginia, The, 88-89

Aristocracy of virtue and talent, An; 74

Armstrong, General, on Florida, 221

Army, with Hamilton as chief, and Federalist officers, projected, 17576,177 ; to overthrow popular liberty, 179; size of the, 179; Ames on use of an, 180; Jefferson on, 198 
Asiatic interests and alliances, 3

Assemblée Nationale, L', Name of, suggested by Jefferson, 56; committee of, on constitution asked Jefferson's assistance, 64 ; not an integral legislature, 115

Auditors placed in one Department, 237

Austria denies expatriation, 15

Authorities on the rights of man, 55-56

Bancroft, George, on the committees of correspondence, 8

Barbary powers, The, put down, 243

Bayard, James Asheton, Claims of, baseless, 189; on Aaron Burr, 191; the creed of, 192; gave off-the-bench opinion of Marshall, 194

Bequests, Limitation of, 86

Bibles, Old ladies hid their, 261-62

Bill of Rights adopted in Virginia, 43

Bill of Rights, embodied in Constitution, 163, 264

Blacksburg, Va., College of Agriculture at, 291

Blackstone on libel, 178

Blockade, Jefferson on, 126

Bookkeeping, Hamilton's system of, 36

Books, Removal of tariff on, refused by Congress, 306-7

Borough, Rotten, system in England, 156, 157

Bosses, Too many, 195

Boston, Closing the port of, a Aeclaration of war, 11; Jefferson's protest against, 18; ten years behind Jefferson in admitting girls to schools, 271

Bread famine in France, 58

British alliance, Hamilton's proposed, 174

British ambassador, Reception of, 234

British captives in Albemarle county, 110

British constitution, our best inheritance, 30; "best form," 148

British Court society imitated, 226

British government "most perfect which ever existed," 157

British House of Lords, The, 147

British model advised for the French, 58
British nation, Arraignment of justice of, 22

Brown, Justice, Decision of, in Downes case, 213

Bryce, James, on the Louisiana purchase, 206

Buckle's "History of civilization," 4

Bull Moose Convention, The, pretended to draw faith from Jefferson, 54

Burke, Edmund, edited Jefferson's "Summary View," 14; failed to see ultimate issue of French Revolution, 59 ; on Chatham, 93 ; rhetoric of, 156,157

Burr, Aaron, Miranda's connection with, 174; had same number of electoral votes as Jefferson, 183; Hamilton's hatred of, 185; Bayard on, 191; something to credit of, 191; conspiracy of, put down, 242 Business, big, Divorce of government and politics from, 159

Cabell, Joseph C., Letters to, 97-98; and State University, 274

Cabot, George, Letters of, 155

Calhoun, John C., far apart from Jefferson, 96

California became a part of the United States on acquisition, 212

Canada, G. Morris on acquisition of, 214; Jefferson had eye on, 221

Canning, and the Monroe Doctrine, 135

Capital punishment, Sole defence of, 72

Careys, The, of Virginia, 89

Carlyle and the French Revolution, 63

Carmichael, William, 112

Carpet-bag authority intimidated, 12

Carr, Dabney, brother-in-law of Jefferson, 10

Carter, Dr. James C., on Jefferson's educational scheme, 266-67

Carters, The, of Virginia, 89

Censors of government, On, 171

Central American republics, The, 3

Ceremonials and etiquette, No bureau of, in State Department, 137

Ceremonies, Forms, cavalcadings and; abolished, 227-28, 230, 243

Channing, a bracer of the republic, 1 
Charles I, Execution of, justified, 17 Charter for the French people, 63

Charters, Rights confirmed not created by, 13

Chatham, Burke on, 93; accepted Newcastle and corruption, 160; on a free people governing dependents, 220

Childs, Dr., Efforts of, in Massachusetts Convention of 1820, 262

Christian Constitutional Society, Hamilton's, 194

Church, Definition of a, 264; separation of, and state, 264

Church membership a requisite for suffrage, 94, 95

Church, State, disestablished, 104, 245; punishments in Virginia for offenses against, 247; levies for support of, 247-48; property of, saved to the, 251-52

Cis-Atlantic affairs, No interference of Europe in, 134, 136

Citizenship, Act defining, 68, 69; education to equip for, 268,273 , 285-89

Civil war imminent, 182, 183

Clarke, George Rogers, sent to the northwestern country, 201, 220

Clarkson, Thomas, 70

Class distinctions ignored, 92

Class hatred of Jefferson, 105

Class opposition to Jefferson's theories, 88-89, 91

Class privileges, Jefferson on abolishment of, 64

Classics, Place of the, 268; and modern languages, 282-84

Clergy, Loss to, of glebes and salaries, 245; levies for support of, 247, 248, 252 ; attempt at a Bill providing for, failed, 252

Coalescence of Kings and beneficiaries of special privilege, 60

Coinage system, 239

Coles, Edward, set free his slaves, 76; letter to, on slaves, 77

College-bred men in Jefferson's Cabinet, 302-3

College students, Duty of, 266

Colleges and universities, Benefits of, 280

Colonies, Greek Republican con- ception of status of, 16 ; practice of British empire towards her, 19; ministry planning to invade the, 22 Colony, Internal regulations of each, 12

Columbia University, 277; study of science of government at, 285

Columbus, Christopher, 217

Committee on Rights and Grievances, Report of, by John Adams, 42-43

Committees of correspondence, Origin of the, 8 ; intercolonial, 8,10 ; revolutionary, 8,11 ; the real government, 10

Committees of safety, 9, 52; Girardin on the, 20; Pandall on the, 20-21

Commonwealth and common weal, 48

Community, Right of any, to change its form of government, 13, 46, 48

Compact, Origin of the neighborhood, 5-6

Confederation, Virginia's assent to a, 12

Congress, An American, 8; a general annual, called for, by Virginia, 11

Congress, Rights of, respecting treaties, 131; should coöperate with the States, 241

Consent of the governed, 46

Constable, The, 6; elective, 102

Constitution, the present, Jefferson in favor of, 34; Hamilton's plan for a, 150-52; views on, 152-54; "a frail and worthless fabric," 153; amendments to, secured by Jefferson, 163; a bulwark of protection for the people, 163; the unwritten, 169; amended, 190-91; an overcoat, 213; Bill of rights made part of, 264

Constitution of Virginia adopted, 43; with Jefferson's preamble, 44

Constitutions, Rights confirmed not created by, 13

Constitutions, state, Jefferson on; $100-1$; adopted by conventions, 101 ; submitted to the people, 102; periodical amendments to, 103

Constructive genius of Jefferson and Hamilton, 35-36

Continental Congress, First movement for a, 11; instructions to Virginia members of, 14-15; Jefferson chosen to, 21, 23; reply to 
Lord North adopted by, 23; committee of, on a declaration of causes, 23-24; adopted a declaration, 24; committee on the "Conciliatory Proposal," 26; desired a lasting union with Great Britain, 30 Contraband, Doctrine concerning, 126

Convention, Powers lodged in a, 15; Jefferson threatened to call a, $186,187,188,189$

Cook, T. A., on the Monroe Doctrine, 134-35

Cooke, John Esten, on the change in Virginia, 92

Corruption essential to government of a nation, 158, 160

Cotton, John, denounced democracy, 94-95

Counter-Revolution, The American, 30 ; overcome by Jefferson, 54, 60; Jefferson foresaw, 85; stemming tide of, 141-95; result of, an amendment to the Constitution, 190-91; defeat of the, 217

Counter-revolutionists, Desperate move of the, 180-81; Jay defeated the, 182 ; had choice of three things, 186; feared a convention, 186-88; checkmated, 189

County, Organization of a new, 6; wards or townships in a, 97-98, 102; administration of a, 102; division of, into hundreds, 269

Court system of Virginia simplified, 69

Courts, Adventitious properties of, 225

Criminal laws of Virginia reformed, 69; preamble to the criminal code, 71-72

Crisis, Hamilton always anticipating a, 154, 173-74; changing electoral vote of New York a, 181; approaching, 183

Cromwell, Treaty of, with Virginia, 17

Cross vs. Harrison, Case of, 212

Cuba, Jefferson had eye on, 221

Curtis, William E., on Jefferson, 19495; on the acquisition of Louisiana, 216-17; on Jefferson's inauguration, 231-32; and manners, 233

De Lima case, The, 212

Death penalty, Removal of the, 69
Debt, The public, 236, 237-38; amount of, pald, 242

Debts due foreigners, Collection of, 114

Debts, Foreign, international, 115

Debts, state, Federal assumption of, 161-62

Declaration of Independence, Essential ideas of, in the "Summary View," 17; Jefferson's account of the writing of the, 30-31; committee chosen to prepare, 31-32; Jefferson the author of the, 33-34; passed, 35 ; an evolution of revolutionary thought, 37; Merwin on, 39; Lincoln on, 39; parts of original draft of, stricken out by Congress, 40; "quotable" and received with enthusiasm, 43; De Witt on, 45; 50th anniversary of, 51; Jefferson's letter to Weightman on, 51 ; a logos, 52; the Soul-Politic of the American people, 54; Jefferson's pride in authorship of, 67 ; opposition to slavery in, 74-75

Declaration of rights, passed by House of Burgesses, 32, 43; adopted by French National Assembly, 64 Declaration of the causes of taking up arms, 23-26; Jefferson's paragraphs of the, 24, 25-26

"Defense of American constitutions," 144

Democracy, The fear of, 2; attacks upon, ineffectual, 55; Hamilton's distrust of, 150; more, the best cure for evils of, 165; judges haranguing against, 175; and education, 266, 286-87; will correct its own errors, 287

Democratic-Republican party, The, 160

Democratic-Republicans, The, founded on Jefferson's political theory, 54 ; ceased to be Jeffersonian, 84

Democratization, of the state, 102-3; of the Federal government, 196

Democratizer of federal institutions, 141-95

Democratizer of state institutions, 67-106

Derk van Capellen, see Van Capellen Descents, Statute of, 73-74 
Dickens, Charles, and the French Revolution, 63

Dickinson, John, member of Committee on declaration of causes, 24 ; kept paragraphs of Jefferson's, 24

Diplomacy, English the official language of, 138; the study of, 285

Diplomatic Corps, Highest titles of our, 139

Diplomatic state papers admired, 129

Disarmament on the border, 139

"Discourses of Davila," The, 143

Disestablishment, Labors for, 24546, 247-51; in Massachusetts, 246, 262; denunciation of Jefferson, because of, 258-63

Dispatches, Jefferson's, 111

Divine right of the "better element" to rule, 192

Doctrinaire, Jefferson called a, 58, 67, 93

Doctrines, hard and unpalatable, 89 Dorset, Duke of, and Jefferson and the Tiers État, 56

Downes case, The, 212-13

Dwight, Theodore, Letters of, 155

Dwight, Thomas, Letters of, 155

Eastern Shore, Great estates on the, 88-89

Economy and liberty, 103

Edinburgh Review on Jefferson, 11112; on Miranda, 174

Education, Aims of the higher branches of, 278; cumulative influence of, 279-80; democracy must provide, 286; government aid for, under Jefferson, 305

Education, primary, The objects of, 267

Education, A system of, necessitated, 55; bill to establish, 68-69; elementary school part of, enacted, 71; general, 96-97, 165; scheme for, presented to the State Legislature, 267-68, 269-71; prizes in grades of, 278-79; keystone to arch of government, 280

Elections, John Adams on, 143-44

Elective studies, 282

Electoral college, Abolishment of, recommended, 241

Emancipation of slaves, Bill for the,
76; and Aeportation; 78, 82-84; a pre-Revolution idea, 217

Embargo, New England's position on the, 120,243

Empire, A well-poised, 19-20

England, Institutions of, 3-4; people of, in accord with King and Parliament, 41

English colonies, Government system in, 164-65

English Government, System of the, 164-65

English-speaking race, Experience of the, 37-38

English the official language of diplomacy, 138; the study of, 283 , 292-93

Entail, Abolition of, 67, 68, 74, 90; result of, 85; Bill for, 88; fight for, 90-91

Epitaph, Jefferson's draft of own, 216, 251

Eppes, Jack, Letter to, 200

Error, Truth and, 244

Esprit, L', des Lois, 4

Estates, stupendous, Disposition of, 90

Estates tail, Act abolishing, 68, 7274,88

Etiquette, Jefferson on, 229, 234

Europe, broils of, No entanglement with the, 134, 136, 200

Executive, Power of, in English Government, 164-65; self-successive, and dictatorship, 168

Expansion under Jefferson and McKinley, 217

Expatriation, The right of, 15-16; first legislative assertion of, 68

Extradition, Question of, 113

Fairfax County, Washington and the resolutions of, 14

Farming, Jefferson on, 291-92

Fathers of countries must put up with free speech, 171-72

Fayerweather, Daniel B., gave gymnasium to University of Virginia, 293

Federal power, Extent of, over the States, 114

Federal Republic of Anglo-Saxony, A, conceivable, 224 
Federalist, The, opposed to popular movements, 164

Federalists, The, opposed observing the French treaties, 118; helped Jefferson, 171; all army officers, 175; plot to keep Jefferson and Burr from being seated, 176, 18081 , 186; feared a convention, 186, 187-88; rank and file of, humiliated, 190; Jefferson's feeling towards, 192-93; effect of Jefferson's administration on, 263

Financial system, Hamilton's, an imitation, 36; his Treasury measures, 160-62

Fiske, John, on Boston tea-party, 9; on seeming state of anarchy, 12; on Jefferson's letter to Randolph on separation, 28; estimate of Jefferson, 35-36; Jefferson no French doctrinaire, 45; on a Federal Republic of Anglo-Saxony, 224; on hiding Bibles, 261

Florida, would be ours in due time, 202-3; the people of, to be citizens, 220; Gen. Armstrong on, 221

Foreign Affairs, Secrecy in Department of, 138

Foreign languages not required of clerks in our State Department, 137

Foreign relations, Our, an expression of Jefferson's policies, 122, 125, 130

Foresight of Jefferson, 2

Forms, ceremonies, and cavalcadings abolished, 227-28, 230, 243

Forms obtaining in State Department, 137

Foster, J. W., anti-Jeffersonian, 122; on credit of United States, 162

France, Revolutionary committee system in, 20; Jefferson in, 56-66; cost of the American war to, 57; domestic violence in, 60; convulsions in, followed in Europe, 62; our treaties with, 116-21; war with did not occur, 173, 174; Hamilton anxious to declare war with, 17980; warning to, about New Orleans, 201, 203

Franklin, Benjamin, a bracer, 1; chairman committee on reply to Lord North, 26; made verbal corrections in Declaration of Inde- pendence, 31, 40; on committee to prepare the, 33; Minister to France, 107; conceived a Federal Republic of English peoples, 224

Frederick of Prussia, Treaty with, 110

Freedom, The love of, 2

Freedom of religion in America, Influence on, 244-65

Freedom of religion, speech, etc., 46 Freedom of speech, 46, 243, 244

Freedom of the press, advocated, 24142,243

French Canal-Bond-Sale, The, 172

French debt, Payment on, suspended, 115; we ought to have paid, 117

French Revolution, De Witt on the, 45; American Revolution one cause of the, 56-57; Jefferson and the, 58-64

French revolutionists, drew from America, 45; regarded us as a model, 56; Jefferson adviser of the, $56,57,58$; violence of, a protest, 60 ; not ripe for their blessings, 62

French soldiers and officers caught the American spirit, 56-57

French West India Islands, The, 133 Freneau, Trouble with Washington over, 127-28; Jefferson on, 171

Frénésie quasi monarchique, A, 228

Frontiersman, Jefferson a, 5-6

Gallatin, Albert, on right to acquire territory by treaty, 210-11; established our treasury system, 238; and the public lands, 303

Gardener, Helen, on Lincoln, 78

Genet, Edmond C. E., Mission of, 121-22; recalled, 124 ; settled in America, 125

George III, Appeal to, in the "Summary View," 19-20; reply of Van Capellen to, 31 ; name of, legislated out of prayer book in Virginia, 32; censure of, stricken out of Declaration of Independence, 40-41

German, Study of, 283

Germany, Institutions of, 3-4

Gierke, Otto, on the rights of man, 38

Girardin, L. H., on committees of safety, 20

Glebes, church, Loss of, 245; restored, 251-52 
Glittering generalities, so-called, 37, $45,46,75$; Lincoln's summary of the, 39,75

God and the Man, 54

Gore, Christopher, Letters of, 155

Government, Germ of dual system of, 12 ; right of throwing off, 13,46 , 47-49; Jefferson a founder of our, 34-35; right to alter or to abolish, 48; bad, the result of too much, 49; a means not an end, 50; liberties and, 53; grades of power conferred upon, 55, 97; precedent for territorial system of, 69 ; the real balance in our, 99; marshalled out into general and lesser republics, 102-3; preference for kingly, spreading, 142-44; Hamilton on efficiency in, 149-50, 161; by popular plebiscite advocated, 165; censors of, 171; libelling the, unknown, 172

Government, Our Federal, the least responsive to result of an election, 164; power delegated to, 209-10; Jefferson on, 212

Government resting on compact, Idea of, 5-6

Government, Science of, as a study, $284-85,287-88,289$

Governments, Recognition of, 116

Grant, rebuked by own party, 166, 167

Great Britain, Lasting union with, desired, 30; and the Monroe Doctrine, 135, 136; centennial of peace with, 139; about to seize New Orleans, 201; could take and hold against France, 204

Greek and Latin, The teaching of, 283, 284

Guadalupe Hidalgo, Treaty of, 212, 220

Guillotine, Lives lost by the, 60

Hamilton, Alexander, a nation builder, 1; not a constructive genius, 36 ; distrusted the masses, 51 ; failed to see ultimate issue of French Revolution, 59; on extent of Federal power, 114; on French treaties and Minister, 118; on Genet, 124; a monarchist, 144, 145, 149, 150, 153; advocated monarchy at Consti- tutional Convention; 147-48; headnotes of speech, 148-49, 150; plan offered to the Constitutional Convention, 150-52; views on present Constitution, 152-54; letters of, 155,174 ; conversation with J. Adams on a "monarchy bottomed on corruption," 156-57, 158; Jefferson on, 158; deemed corruption essential, 158-59; idol of the monied classes, 159; Treasury measures of, 160-61; in the Federalist, 163-64; his philosophy of government, 170 ; H. C. Merwin on, 17374 ; on a permanent army, 175-76, 177; advised division of Pennsylvania and Virginia, 176; on libels against government officials, 177; anxious for a war, 179-80; letter to Jay on changing vote of New York, 181-82, 186; military ambition of, 182-83; hated Burr more than Jefferson, 185, 189; questioned repeal of the judiciary act, 194; "Christian Constitutional Society" of, 194

Hamilton, John C., biographer, 148 Hanover County, Resolutions of, 14 Harbors of refuge, 110

Harlan, Justice, Dissenting opinion of, in the Downes case, 213-14

Harmony of the bold with the cautious in Virginia, 7

Hart, A. B., on Jefferson's discretion, 203-4; on the acquisition of Louisiana, 215; on our treasury system, 238

Harvard University, 277

Hazen, calls Jefferson a republican militant, 58; on Jefferson's views of the French Revolution, 59

Henry, Patrick, and resolutions of Hanover County, 14; opposed to Constitution, 34

Hero-worship, the great danger of a democracy, 235

Hill, A. P., Stonewall Jackson's last words an order to, 52

History, The study of, 269, 288-89

Hoar, Senator, on Jefferson, 216

Home-making, Vast territory for, 216; 217

House of Burgesses, Meeting of, in 
the Apollo Room; 10, 11; called for a general congress, 11 ; instructions to delegates, 11-12; resolutions of, for independence, 32

House of Commons, Powers of, 16465

House of Lords "a most noble institution," 147

House of Representatives, to determine between Jefferson and Burr, 183-84; plan for, to reorganize the government, 186

Huger, on Jefferson's election, 184, 186, 190, 191

Hugo, Victor, 245

Humaneness, legislative, First example of, 69

Hundreds, Counties to be divided into, 97, 269; military company and school in each, 269

Illinois, Education in, 281

Immigration, Restriction of, 140

Impressment, Question of, 132

Inaugural processions, expensive and dangerous, 234

Independence, hastened by communication from R. Penn and A. Lee, 28-29; increase of advocates of, 31

Independency, Jefferson nearing, 28

Indiana, Education in, 281

Indians, Land acquired from, by treaty, 239-40

Individual, The, his own governor, 46; and the Divine Individuality, 54

Influence, Jefferson's, how treated, 4; as a diplomat, 107-40; as president, 196-243; on freedom of religion, 244-65; on our educational institutions, 266-307

Influence, political, A man's, 4

Inheritance, Limitation of, 86

Institutions, Permanency of a nation's, 2-3; what are, 3-4; informing spirit of our, 7; dangers to, 168; debt of our, to Jefferson, 184; reverence for, 235

Internal taxes abolished, 236

International law, Correspondence with Hammond on, 139

International relations, Jefferson's impress on our, 112; message on,
128-29; successfully managed by Jefferson, 130; correspondence with Hammond on, 139; all power with regard to, resides in the Federal Government, 210-11

Interstate commerce, Power of Congress over, $240-41$

Intimidation, So-called, of an Administration, 18

Intolerance and incompetency in the church, 246

Iowa, Education in, 281

Italian, Study of, 283

Italy, Institutions of, 3-4

Jackson Democrats, The, 29-30

Jackson, Stonewall, Last words of, 52

Jacobins, How the French became, 60-61

Japanese, The, and the classics, 283-84

Jay, John, on a King, 146; dreaded popular movements, 164; rejected Hamilton's scheme, 181-82, 186

Jay Treaty, The, 112, 131, 132; Washington's humiliation of signing, 197

Jefferson, Andrew D. White on, 1-2; the man, 4 ; his environment, 5-6; the revolutionist, 7-66; in America, $7-56$; member of House of Burgesses, 13; on the "Summary View," 14-15; proscribed, 14, 17; always in advance, 17; "timid" and "vacillating," 17, 20, 23; chairman of Committee of Safety, 20, 21; member of Continental Congress, 21, 23; Reply to North's "Conciliatory Proposal," 21-22, 23, 26; draws up Declaration of causes of taking up arms, 24, 25-26; member of committee on Lord North's "Proposal," 26; on first idea of separation, 28-29; corrected Adams' error about Declaration of Independence, 30-31; chairman of committee on Declaration, 32, 33; legacy of class hatred of, 33 ; a founder of our Government, 34-35; faith of, in the people, 36 ; on rights of man, 38; his original draft of the Declaration of Independence, 40; on Adams' and Pickering's 
observations, 41-42; "plan of government" for Virginia, 43-44; on the business of government, 49-50; on love for and distrust of the people, 50-51; on the Declaration, 51 ; last words of, 52 ; parties based on political theory of, 54; its salient points, 55; in France, 5666 ; modesty of, 56, 64-65, 67; and the French revolutionists, 56, 57, 61-66; a Celt, 57; on what was best for France, 57-58; his hope for France, 58-61; four great measures of, 67; inscription for tomb of, 67; acts of constructive legislation, 68-70; on freeing his slaves, 75$76,77-78$; on importation of slaves, 76 ; on emancipation and deportation, 78, 82-84; a logos, 82; prescient wisdom of, 83 ; a conservative reformer, 85 ; on limitation of bequests, $86-87$; in Virginia House of Delegates, 87-88; an apostle of local self-government, 96-106; Watson on work of, 104; on state governments, 104; mind of, a laboratory, 105; as a diplomat, 107-40; Minister to France, 107-8, 111; the Model treaty, 108-11; as Secretary of State, 112, 114-15, 129; on the French debt, 115; on the French treaties, 117-18; on neutrality, 122-23; on Genet, 124, 125; on our relations with foreign nations, 125; on free goods, blockade, and contraband, 126 ; resigns from the Cabinet, 126, 128; Report on foreign commerce, 129; on rights of Congress and President respecting treaties, 131-33; the Monroe Doctrine, 133-36; stemming the counter-revolution, 141-95; a practical man, 142; election of, in 1800 , our second revolution, 155; on conversation of Adams with Hamilton, 156-57; secured amendments to Constitution, 162-63; on term for President, 165-67; refused third term, 166, 169; elected Vice-President, 170; schemes to defeat election of, as President, 181-90; elected by the people, 183; had same number of electoral votes as
Burr, 183; victory of, 184, 189; denied right of Congress to reorganize government, 186; threatened to call a convention, 186-89; refused to make terms, 188; defeated the Federalists, 189; on the result, 190; inaugural address of, 193; on error, 193; Curtis on, 195; influence of, as President, 196-243; our reasons for peace, 197-98; on an army, 198; on Leopard-Chesapeake incident, 199; hoped for a new era, 200-1; the expansionist, 201 ; on marrying the British fleet and nation, 203; discretion of, 203-4; on the Louisiana cession, 205-6; and Napoleon, 206; the purchase, 206-7; doubts of, on acquisition of territory, 208, 209-10; mistake of, 211; on powers of Federal Government, 212; annexed contiguous lands, 217; broad vision of, for expansion, 221-22; ordinance for Northwest Territory, 223; and Washington, friends, 228; reception to ladies at levee, 230; inauguration, 231-32; as President he was the court, 233; afraid of hero-worship, 235; father of our coinage system, 239; on freedom in religion, 244, 245; member of Committee on religion and morality, 246; Bill for religious freedom, $249-50,253-56$; religious views of, $257-58$; denunciation of, 258-63; as a political manager, 263; made a LL.D. at Harvard, 266; educational scheme, 267-71; project for a State University, 272, 274-75; Rector of University, 275; Report of, 276, 277-79; strong in preambles, 280; on State Literary Fund Board, 300-1; stupendous conceptions of, 303-4; a spendthrift economist, 304-5; petition for removal of duties on books, 305-6; for education to the last, 307

Jefferson Bible, The, 258

Jefferson College, in Mississippi, Foundation of, frittered away, 304 Jefferson, Letters of, quoted: To Wm. Wirt, 7; to John Randolph, 28, 30; to Du Pont de Nemours, 50; to 
Mayor Weightman on the Declaration, 51 ; to $\mathrm{Mr}$. Short on the French Revolution, 61; to E. Coles on the slaves, 77; to Franklin on the change in Virginia, 92-93; to Gov. Tyler on education and hundreds, 96-97; to Cabell on education and wards, 97-98; to Kercheval on townships, 98; to Kercheval on state constitutions, $100-1$; to E. Rutledge on the Jay Treaty, 131; on Monroe Doctrine, 134, 136; to John Taylor on President's term, 166-67; to Madison on defeat of the Federalists, 189; to Noah Worcester on peace, 196; to Eppes on European wars, 200; to De Marbois on expansion, 222; to Madison on adulatory titles, 226-27; to Gallatin on finances, 235-36; mistake in publishing, 258; to Dr. Rush on tyranny over mind of man, 259; to Wythe on democracy and education, 266; to Cabell on primaries, 281; to De Onis on suffrage in Spain, 286; to Kosciusko on reading for young men, 288; to Williams on farming, 291-92; to Peter Carr, 289, 293; to Roscoe on truth, 294; to Cabell on the wealthy, 295-96; to Wyche on county libraries, 300-1; to Cabell on his own work for the University, 302

Jeffersonian simplicity, 103, 139, 225-39; called simply Mr. Jefferson, 226; abolished forms, ceremonies, and mysteries, 227-28, 230, 243; dislike of public scenes, 228; at White House, 229; Curtis' slur at, 231-32; criticism of, 233-34; of forms, 235 ; in the Treasury Department, 235-38

Jeffersonian spirit, The, 216-17

Jeffersonian theory, see Political theory, Jefferson's

Jefferson's Ana, 142, 156, 228

Jefferson's "Manual," 170

Jefferson's portrait in Bull Moose Convention, 54

Jingues, Words too wise for, 198

Johns Hopkins University, Study of science of government at, 285
Judges, Election of, 101; Hamilton's proposed, 178

Judiciary, The, to overthrow popular liberty, 179

Judiciary Act, Repeal of the Federal, 194

Jurors to be elective, 103

Jury system, recommended to National Assembly, 65

Justice of the peace, The, 6 ; to be elective, 102, 103; federal, to hunt down "libellers," 178

Kean, R. G. H., on Act abolishing slave trade, 69-70; on the statute of descents, 72-73

Kentucky Resolutions, The, 96, 145, 175

Kentucky, Transylvania University founded in, 282

Kercheval, Samuel, Letter to, 98

King, the English, Hamilton on, 147$48,150,151-52$

King, Rufus, Letters of, 174

Kingship, A common, the sole binding tie, 19

Know-Nothing movement, The, 172

Knowledge will govern ignorance, 280

Knox, Henry, a monarchist, 144, 145

Ku Klux Klan, The, 9

Lafayette, Jefferson's advice to, 57; banquet to, attended by Jefferson, 296-97

Land, subjected to the payment of debts, 91

Landholders, Small, 87

Lands, Public, given for education, 303-4

Language, Lucidity of, 69; law, reformed, 70

Languages, modern, Jefferson champion of, 300

Law revision committee of Virginia Legislature, 70; report of, 268

Laws and institutions, Reverence for, 235

Leadership, Political, 195

Lee, Arthur, messenger to Great Britain, 28-29

Lee, Henry, advised making Marshall president, 162

Lee, Richard Henry; Dean of Virginia 
delegation, 32, 35; opposed to the Constitution, 34 ; charged plagiarism, 42; favored clergy Bill, 252; on avarice and religion, 253

Lee, Thomas L., member of Law revision committee, 70

Lees, The, of Virginia, 89

Legislature of Virginia, see House of Burgesses

Legislature, One, may not infringe on rights of another, 19, 21

Leonard, Daniel, on the committees of correspondence, 10

Leopard-Chesapeake incident, Jefferson on the, 199

Letters, Hoards of, unpublished, 155

Lex talionis, Protest against, 69

Libels, Hamilton urged laws against, 177; Blackstone on, 178

Liberties and government, 53

Liberty, An empire for, 201-24, 216, 221

Library, Jefferson's private, 294

Library, Public, Bill for a, 268, 271; letter on, 300-1

Lincoln, Abraham, on the Declaration of Independence, 39,75 ; a Jeffersonian, 54; Helen Gardener's portrayal of, 78; faith of, in the people, 193

Livingston, Robert R., member of committee to prepare Declaration of Independence, 33; Minister to France, 126; and the Louisiana purchase, 202-3, 207

Locke, John, "Treatises of Government" of, 37, 42

Lodge, Henry Cabot, on committees of correspondence, 8; on Jefferson, 104; on the monied interests, 161-62

Logos, The Declaration of Independence a, 52

Louis XVI dethroned, 115, 118

Louisiana Territory, Acquisition of, $140,214,242$; story of, 202-9; ceded by Spain to France, 202; negotiations for, 202-6; Hart on the, 215; aims attained by the, 21516 ; status of citizens of, under treaty, 218, 220; Spanish and French laws re-enacted for, 218-19; states carved out of, 223
Louisiana Treaty submitted to Congress, 131

Loyalists, The, in New York, 145-46 Lyon, Matchew, cast vote of Vermont for Jefferson, 189

Mabie, H. W., on the University of Virginia, 299, 300

McKean, Thomas, governor of Pennsylvania, 188

McKinley, William, annexed distant possessions, 217

Madison, James, favored adoption of Constitution, 34 ; reported Hamilton's Convention speech, 147, 148, 150 ; on powers of Federal Government, 210-11; opposed clergy Bill, 252 ; appealed to people, 253; favored State University, 274, 275

Majority, A parliamentary, 160

Man, God and the, 54; land and the, 91

Maryland, Religious toleration established in, by the Roman Catholics, 251

Marshall, John, on Jefferson, 111, 129-30, 184-85; mentioned for presidency, 186; Lee favored, 192; off-the-bench opinion of, 194

Mason, George, opposed to the Constitution, 34; drew up first Constitution of Virginia, 44; member of Law revision committee, 70; opposed clergy Bill, 252, 253

Mason, One Dr., on Jefferson, 259

Massachusetts Bay rejected aristocracy as a form of government, 95

Massachusetts, Church support compulsory in, 262

Mazzei, Story of, against Jefferson, 259

Mellen, G. F., on Jefferson and higher education, 300

Men of the hour dangerous in a crisis, 168

Mercer, James, in Virginia Assembly, 21

Merriam, Charles E., "American political theories," 38 ; on the American working hypothesis, 46; on the theocratic government in New England, 94-95

Merwin, H. C., on Hamilton's 
"crisis," 173-74; on Jefferson's simplicity of forms, 235

Mexico, 3; Territory acquired from, 220 ; states out of, 223

Michigan, State University created in, 273,282

Milton, John, "Defense of the English People," 37; "License of public printing," 245; "Tenure of Kings and Magistrates," 37

Ministers abroad, Instructions to our, 109

Ministers, Foreign, national not dynastic agents, 118

Minnesota, Education in, 281

Miranda, Francesco, revolutionist, 174

Mississippi, Constitutional conventions in, 102

Mississippi River, Right of navigation of the, 112-13, 215, 217, 222-23

Mohawk Indians, The, of the Boston tea-party, 9

Monarchical party, Existence of a, 154; Washington thought, dead, 160

Monarchists, Large numbers of, 145

Monarchy and democracy, Long contest between principles of, 143,145

Monied interests, Tying the, to the government, 161-62; not necessary, 243

Monocrats, Many Whigs among the, 146

Monroe, James, consulted and followed Jefferson, 135; governor of Virginia, 188; and Livingston, negotiators, 203, 207; and State University, 274

Monroe Doctrine, First inkling of the, 133; expressions of, 134-35; full born, 136

Montesquieu, 99, 157

Montmarin, Count de, on salt beef, 108

Moral sense, Influence of, on government, 51

Morris, Gouverneur, on protecting French nobles, 61; Jefferson did not confide in, 62; character of, 63; instructions to, on French debt, 115; to Walsh on Hamilton, 152, 153; to Ogden, 154; a reactionary, 154; to Ogden, on Hamilton, 183; to
Hamilton on election of Jefferson, 184, 186; favored Jefferson's election, 189-90; obeyed will of the people, 191; on desperate measures, 192; on acquisition of Canada and Louisiana, 214

Morris, Robert, Action of, elected Jefferson, 189, 190; obeyed will of the people, 191

Morse, J. T., on Jefferson's reply to North's "Proposal," 26-27; on the Louisiana purchase, 202

Napoleon, Victories of, useless to us, 117; might have succeeded, 120; purpose of, in selling Louisiana, 204-5, 206, 207-8; ante-dated the Treaty, 208

National bank, Hamilton's scheme for a, 161-62

National sentiment the condition of national existence, 152

Nations, Intercourse of, under the model treaty, 109

Naturalization of foreigners, Bill for the, 91 ; law for, 140

Necker, Jacques, on the British Constitution, 147, 157

Negro postmistress, $\mathbf{A}$, and a closed post office, 18

Negroes, Freedom for, as a race and as a few individuals, 77-78; the American people like free, 155

Nelson, Hugh, presented Jefferson's petition for removal of duties on books, 305-6

Nelsons, The, of Virginia, 89

Neutral property in war-time, 109

Neutral ships and free goods, 126

Neutrality, Declaration of, 120; Jefferson on, 122-23

New England clergy hated Jefferson, $259,261-62$; odium theologicum partially disarmed, 263

New England Magazine, on heterodoxy of Adams and Jefferson, 245

New England, Monarchical ideas in, 146; threats of dissolution in, 208-9

New Orleans, Great Britain about to seize, 201; France and, 203; Hart on Jefferson's policy, 203-4; Napoleon and, 204-5

New York, First movement for a 
Continental Congress came from, 11; worse thing than primo-geniture in, 90; electoral vote of, for Jefferson, 181; Hamilton's scheme to reverse, 181

Newcastle, Duke of, and corruption, 160

Newspaper reporters given desks in Congress, 305

Nicholas, George, 21; opposed entail Bill, 91; opposed Clergy Bill, 252

Night schools suggested by Jefferson, 289

North, Lord, "Conciliatory Proposal" of, 21; Jefferson's reply to, $21-22,23,26,42$

Northwest Territory, Bill of 1784 for government of, 69,223 ; slavery excluded from the, 76-77

"Notes on Virginia," Jefferson's, 2829; liberal sentiments in, 57; opposition to slavery in, 74; freedom of religion, 244, 246; Bill for religious freedom in, 248, 264; pirated edition of, in Paris, 265 ; on study of language, 284

Nurselings of luxury, 89

Officers of the general government, Protection of, from libel, 177-78; superiority of, over the mass of the people, 225

Offices, Unnecessary, abolished, 237

Ohio, Public lands given for education in, 303

Old Line Whigs, The, 29-30

Oligarchs, The Confederate, 80

Opinion, An, punished, not an act, 18 ; source of, 254 ; not subject to jurisdiction, 255, 264

Opponents, political, Traditional courtesy of, in Va., 90-91

Oppressions, A series of, denounced in the "Summary View," 16-17

Oregon country, Claim on, secured by Jefferson, 221, 243

Otis, Harrison Gray, Hamilton's letter to, on war, 179-80

Otis, James, Reference by Adams to pamphlet of, 41-42; conceived a Federal Republic of Anglo-Saxony, 224

Overseers, school, Duties of, 269-70
Pages, The, of Virginia, 89

Paine, Thomas, Jefferson kept promise made to, 259-60

Parliament, had no right to interfere in the colonies, 21-22; people of England in accord with, 41

Parmelee, Mary P., on Jefferson, 105

Parton, James, on Jefferson in France, 64-65; on the model treaty, 109 , 110 ; on the change of sentiment, 142,143 ; on Jefferson's "family soup," 225; on liberty of belief, 263

Patronage, Hamilton's salutary, 17879; executive, abolished, 237; reduced, 242

Peace, My passion is, 196, 199; our reasons for, 197-98

Peace-at-almost-any-price policy, 196; wisdom of, 199, 243

Penalties, brutal, Amelioration of, 69 Pendleton, Edmund, member of Law revision committee, 70; opposed abolishing entails, 91 ; and primogeniture, 92

Pendletons, The, of Virginia, 89

Pendulum, standard of measure, 239

Penn, Richard, and A. Lee, reported the King's reply, 28-29

Penn, William, Definition of free government, 95

Pennsylvania, First constitution of, 48; division of, advised by Hamilton, 176; troops mobilized in, 176; vote of, to be thrown out, 182; would protect a convention, 187, 188

People, Jefferson on love for and distrust of the, 50-51; Woodrow Wilson on the, 50; Hamilton distrusted the, 51; not Americans, 125; John Adams on the, 143-44; "your, is a great beast," 153, 158; will of, must be done, 191; faith in common sense of the, 193

Petition, The right of, 46

Philippines, World-powering in the, 3 , 220; status of, 211, 212; of people of, under the treaty, 218; no constitutional protection for, 219 Physical culture and national defense, 293-94

Pickering, Timothy, published Adams'. 
criticism on the Declaration, 41, 42 ; letters of, 155,174

Pilgrim Fathers, The, and the Puritans, 95

Pitt, the Elder, see Chatham

Plagiarism, No, by Adams or Jefferson, 43

Planter, The rich, and the University, 295-96

Plumer, W., Letters of, 155

Political theory, Jefferson's, Parties founded on, 54; the Soul-Politic, 54; salient points of, 55 ; source of, 55

Politicians, conscious hypocrites, 159, 193

Politics, big, Divorce of big business from, 159

Porto Rico did not become a part of the United States on acquisition, 212 ; status of people of, under treaty, 218; no constitutional protection for, 219

Possessions, distant, with alien populations, What to do with, 213; annexed by McKinley, 217

Post office, under a negro postmistress, closed, 18

Powell, E. P., on A suppressed chapter of American history, 143; on Michigan University, 273; on Jefferson, 274

Powers, not delegated reserved, 34, 45-46, 163; doctrine of delegated, 48-49; grades of, conferred upon government, 55,97 ; state and national, 55; all, with regard to foreign affairs, delegated, 209-10

Preamble to Virginia Constitution, Jefferson's, 44, 57, 69; to Bill for better diffusion of knowledge, 280

President, Rights of the, respecting treaties, 132; term of office of, 16568,243

Primogeniture, Abolition of, 67, 68, 74 ; result of, 85 ; bill for, 88,90 ; fight for, 90-91; Pendleton opposed, 92

Princeton University, 277

Principles of the Revolution, Reaction against the, 2

Prisoners of war, Treatment of, 109-10

Privileges, special, Beneficiaries of, 60; Jefferson urged withdrawal of, in
France, 62; abolished by the National Assembly, 64

Profusion and servitude, 103

Property, Unequal division of, 86-87

Protective system, The, in France, 108

Prussia denies expatriation, 15

Pure Republic, Definition of a, 95, 98

Purtans, early, Government of the, theocratic, 94-95; distinction between and the Pilgrim Fathers, 95

Quakers, Political ideas of the, 95

Quincy, Josiah, on dissolution of the Union, 209

Rabble, The, and the aristocracy, 286-87

Race problem, The, 80; Jefferson on the, 83; Lincoln on the, 84; the South's drawback, 89

Raleigh Tavern at Williamsburg, 10, 11

Randall, H. S., on committees of safety, 20-21; on class hatred of Jefferson, 70; on the Revolution, 146; the original Bill for religious freedom, 249-50

Randolph, John, Letters of Jefferson to, 27-28; emancipated his slaves, 76 ; on the American reign of terror, 175; venom of, 221

Randolph, John, of Roanoke, 27, 89, 201

Randolph, Peyton, presented Jefferson's resolutions to the Convention, 14; asked Jefferson to reply to North's "Conciliatory Proposal,". 21

Randolphs, The, of Virginia, 89

Reactionaries, Utterances of the, 143-45

Reciprocity, Stimulus to, 107

Recodification, Brevity and succinctness of the, 71

Reconstruction, a fool's errand, 3; the mad saturnalia of, 83,177

Reform, political, A B C of, 159

Regulating Act, Impossible to execute the, in Massachusetts, 12

Religion, Difference of opinion in, 244, 245; punishment under Virginia Act for denial of, 247

Religious freedom, Jefferson's statute 
of, $57,67,68,70$; results of, 85 ; first in the world, $245,246,247$, 248, 251; excerpt from, 249-50; passed, 253-54; amendments to, 254-56; 263-64

"Reply to Lord North's Conciliatory Proposal," 21-22, 23, 26, 42

Representation, Equal, in the legislature, 103

Republican government radically defective, 152

Republican party, The, founded on Jefferson's theory, 54

Republicanism, Catholic principle of, in recognition of governments, 11516

Republics, The lesser, 97, 99-100, 102-3

Resolutions for Committee of intercolonial correspondence, 8; offered in the Assembly, 10

Revenues, Increase of annual, 215

Revision work in Virginia, 68-70, 85; Bill for revision of the laws, 88

Revolution, The American, a cause of the French, 56-57

Revolutionary intimidation, 12

Revolutionary period, Political theory of the, 47-49

Revolutionist, The, 7-66

Rhode Island, Religious freedom in, except for Catholics, 251

Right of revolution, 47-48

Right to a thing, The, gives right to means for use, 112

Rights of man, The, 13; Van Capellen on, 31; declared in the Roman Digest, 38; the object lesson of, in America, 39; De Witt on, 45; business of government to make, more secure, 50 ; letter to Weightman on, 51-52; the political scientists and, 53-54; natural, inalienable, God-given, 55; authorities for, 55-56; Jefferson a forerunner of, 57; unviolated, 85; the Puritans not enthusiastic for, 95; in Bill for religious freedom, 250, 256-57; the citizen should know his, 267

Roman Catholics refused religious liberty in Rhode Island, 251; established it in Maryland, 251
Roman Digest, The, expressed the natural rights of man, 38

Roosevelt, Theodore, on Jefferson, 17, $20,23,54,104$; rebuked by both parties, 166; wanted third term, 167; spirit of sedition laws under, 172; on "infamous conduct," 196, 199

Rousseau, Jefferson opposed to central principle of, 38; Jefferson no disciple of, 45; difference between Jefferson and school of, 49-50; not quoted as authority on rights, 56

Rousseau's "Contrat social," 5

Rowe, John, at Boston tea-party, 9

Russia, Treaty with, abrogated, 15-16

Rutledge, Edward, Letter to, 131

Rutledge, John, on Jefferson's election, 185

Sabine, Lorenzo, "American Loyalists," 145

Salt beef, in France, 108

Schools, Common and Grammar, Bill to establish, 268; provision for common, and overseers, 269-70; for grammar or central, 270-71; districts and Boards of overseers, 270 ; duties of visitors, 271 ; coeducation in, 271; primaries, 281

Schools, Grammar or central, Land and buildings for, 270; promotion to, from common, 270-71; from, to University, 271

Schouler, James, on Jefferson and the University, 299

Scientists, The political, and the rights of man, 53-54

Search and arrest, Freedom from unreasonable, 46

Secession, Right of peaceful, denied, 47

Secretary of State, Jefferson appointed, 112; handicapped by Senate's right to amend a treaty, 138

Sedgwick, Theodore, reactionary, Letters of, 155

Sedition laws passed, 145; a blunder, 170 ; result of, 171 ; failure of, 242 Self-extinguishment, The right of, 53 Self-government, Capacity of American people for, 12 ; inherent rights of, 13 
Self-government, Local, 55; an apostle of, 96-106; Jefferson on, 98-99

Self-preservation, first duty of a nation, 117

Shays's Rebellion, 2, 141

Sheriffs to be elective, 103

Sherman, Roger, member of committee to prepare Declaration of Independence, 33

Ships of war and prizes, French, admitted to our ports, 119

Short, Mr. Jefferson's letter to, 60-61, 112,134

Sidney, Algernon, "Discourses on Government," 37

Slave owners, Difficulties of, 78; kindliness and heroism of, 79-80

Slave-trading, References to, stricken out of Declaration of Independence, 40; Jefferson right about, 41; Act to abolish, 69,80

Slavery, Jefferson's opposition to, 74-78, 81-83; efforts to prohibit, in all territories, 76-77; defence of, a defence of aristocracy, 80-81; Jefferson's words against, a logos, 82

Smith, Adam, 224

Smith, Samuel, denied claims of Bayard, 189

Social contract, $A$, at the base of government, 5

Social order, Hamilton's view of, 181

Social structure, The, aristocratic, 88

Soul-Politic, The, within our BodyPolitic, 4, 54; making over the American, 281

Sovereignty of the people, 47

Spain, Diplomatic correspondence with, 129; Holy Alliance and South American colonies of, 135; would need to sell Florida, 203

Spanish, Study of, neglected, 284

Sparks, Jared, battled for removal of tariff on books, 306

Spanish milled dollar, basis of value, 239

Speech, Freedom of, 46

Speeches from the throne, No, for Jefferson, nor since, 229

Spooner Amendment, The, 219

State, The, the safeguard of republican institutions, 96; a lesser re- public, 97, 99, 102-3; true barrier of liberty, 105

State Department, Forms and etiquette in the, 137, 139

Stephens, Alexander, 24

Suffrage General, 103; educational qualification for, 286-88

"Summary View," Jefferson's, printed by the Virginia Convention, 14-15; a mine for ideas and phrases, 15; basis of argument in the, 15-16; forerunner of the Declaration, 16$17,42,57$; justified execution of Charles I, 17; protest against closing port of Boston, 18-19; appeal to George III, 19-20; opposition to slavery in the, 74

Supreme Court, Contradictory decisions of the, 212

Sweden and Norway, Separation of, 47

Table, Things not of the first, 47; things of the first, 55; the first and second, defined, 94

Talleyrand, offered Louisiana to Livingston, 203, 215

Taxes, Some old, abolished, no new created, 238; reduced, 242

Tea, thrown overboard in Boston, 9; House of Burgesses on purchase of, 10; the punishment for, 18

Teachers, free and untrammelled, 294-95

Tennyson and Jefferson, 288

Territory, acquisition of, Early doctrine of, 210-11; new doctrine, with regard to the Philippines and Porto Rico, 211, 212-14; a means, not an end to Jefferson, 216

Texas, Public lands of, 303

Theological Seminaries, to be established by the churches, 274

Ticknor, George, Visit of, to Jefferson, 300

Tiers Etat, Leaders of the, consulted Jefferson, 56

Titles, Adulatory, proposed, 226-27

Titles, Honorary, 137, 139, 226

Tories, Position of Revolutionary time, 48

Tourgée, Albion W., 3

Town-meeting methods opposed, 142 
Township system in New England, 93; Jefferson enamored with, 96; elementary republics, 97-98; power of, 98; vital principle of government, 98

Trade preferences voluntary, $19-20$

Trade regulations, Unbearable, 16

Transylvania University, Causes of failure of, 282

Treason, Jefferson's act defining, 68, 72 ; instructions on, 113

Treasury measures, Hamilton's, 16061

Treasury system Gallatin's not Hamilton's, 238

Treaties, Interpretation of, in relation to dual character of our Republic, 113-14; Jefferson wary of, 199

Treaties with France, Our, 116-21; violation of, 117, 130

Treaty effected by Monroe in 1806 not sent to Senate, 132

Treaty of Amity and Commerce with France, 118-19; provisions of, violated, $119-20$

Treaty of Paris of '63, 112

Treaty of 1782-83, 112

Treaty, The Model, 108-11

Treaty, Right of the Senate to amend a, 138

Tucker, George, on desperate measures, 192

Tuition and board, Free, in grammar schools, 270

Tyranny, submission to, or resistance by force, Jefferson on, 25-26

Tyler, Governor, Letters to, 96-97

Umpirage of reason, The, for collisions of interest, 198

Union for the colonies, A, effected by the correspondence committees, 8

Union, The, acknowledged and emphasized by Virginia, 22; right of a state to withdraw from, not doubted, 120; must be strengthened, 152-53; Hamilton's devotion to, 164; dismemberment of, 182, 208-9; Josiah Quincy on dissolution of, 209

Unit of value scheme, 239

Unitarianism of Jefferson, 257
United States, A legal government of, 35; credit of, in Amsterdam, 162

United States Bank, Stock of, sold, 236

University, A national, favored by Washington and Jefferson, 276-77; arguments against, $\mathbf{2 7 7}$

University of Geneva, Scheme to transfer the, to Richmond, 303-4

University of Virginia, Father of the, 67; laws for establishment of, 69; cardinal features of, 272 ; founded, 275; organization of, 282-83; no school for science of government at, 285; agriculture, etc. at, 289, 29091; a gymnasium for, 293; the Library and the teaching force, 294-95; success of the, 295; Jefferson on, 295-97; treated niggardly by Virginia, 297; influence of, 29798; freedom at, 298-99; Schouler on, 299; Mabie on, 299-300

University, Purpose of a, 274; each State should have a, 276-77

Value, Unit of, scheme, 239

Van Capellen, Johan Derk, Reply of, to George III, 31-32

Vanity of authorship, Jefferson had no, 24

Vest, Senator, on Jefferson, 129

Virginia convention, called to elect delegates to Congress, 11; instructions to members of Congress presented to the, 14-15; the first of its kind, 15; Dr. Grigsby on, 104

Virginia Dynasty, Jealousy of the, 261 Virginia Resolutions, The, 145, 175 Virginia, Sole tie binding, to England, 19; would not desert her sister colonies, 22; reply of, to Lord North, 20-23, 26; a written constitution for, 32, 43-44; instructions to representatives to move independence, 32, 35, 43; efforts to stop slave trade in, 41; Bill of Rights and Constitution of, adopted, 4344, 100; Jefferson's work of reconstruction in, 68-70, 85 ; recodification in, 69, 71; emancipation and non-importation of slaves in, 76,80 ; what held, back, 89; a State made over, 92-93; followed Jefferson, 93; 
constitution of, attacked, 104; division of, advised by Hamilton, 176; troops mobilized in, 176; would protect a convention, 187, 188; fell short of Jefferson's ideas, 289; citizenship of, 296; neglects her University, 297

Virginia State Literary Fund Board, 301

Visitors, school, Duties of, 271

Walcott, Oliver, pussy-footed old Counter-Revolutionist, 156

Walker, Francis, on passage of sedition law, 170; on Hamilton's philosophy of government, 170-71

Walker, John, member of House of Burgesses, 13

Walpole, Robert, and corruption, 158

War, Waste in preparation for, 198-99

Wards, Counties to be divided into, 97-98, 102-3

Washington, George, a founder, 1; on the model treaty, 110; supported Jefferson against the Cabinet, 115, 124; criticised, 125; persuaded Jefferson to remain in Cabinet, 127, 130; relations with Jefferson, 128; idea of making, king, 146; on a monarchical form of government, 146-47; refused third term, 166, 243; humiliation of, in signing Jay Treaty, 197; started us as the Great Peace Nation, 197; birthday balls of, 226; titles proposed for, 226-27; with sword and cocked hat, 227, 229; favored Bill for supporting clergy, 252; to Mason, on, 252-53; influenced Jefferson, 304

Washington's Cabinet, 160

Watson, Thomas E., on democratized Virginia, 93; on the work of Jefferson, 104; on Napoleon's victories, 117; on Jefferson's peace policy, 199

Webster, Daniel, on Jefferson, 111, 129

Webster, Sidney, "The Two Treaties of Paris," 214, 218-19

Weightman, Letter to Mayor, 51
West, Possession of the, a bond of union, 222-23

Western states, Separation of church and state in, 264; liberal to their universities, 297

Whigs, The early, made pretense of Jefferson's theory, 54

White, Andrew D., The six architects of our republic, 1; on Jefferson, 1-2, 80; Jefferson's opposition to slavery, 81-82

Wiley's, Dr., interesting work, 291

William and Mary College, Bill for amending the Constitution of, 268; never enacted, 271; chemistry at, 284

Williams, Roger, on things not of the first table, 47; stood for democracy, 94; in accord with Jefferson, 94-95

Wilson, Woodrow, on those who distrust the people, 50

Winship, A. E., and R. W. Wallace, on the Louisiana purchase, 204

Wirt, William, Letter to, quoted, 7

Wisdom, The prescient, of Jefferson, 83

Witchcraft, Law against, in Virginia, 265

Witt, Cornelius de, on the Declaration of Independence, 45 ; on the authorities for rights, 55-56; on Jefferson in Paris, 57-58

Women, Education of, 272

Woods, the, Our beginnings in, 39

Woodward, Judge A. B., created Michigan University, 273

Worcester, Noah, Jefferson's letter to, 196

World democracy and world peace, 200

Wythe, George, agreed with Jefferson, 13; member of Law revision committee, 70; set free his slaves, 76; shared Jefferson's religious views, 257

Yale University, 277

Young men consulted Jefferson on their reading, 287-88

Charleg Alexander Nelgon 


\section{COLUMBIA UNIVERSITY PRESS}

Columbia Univereity in the City of New York

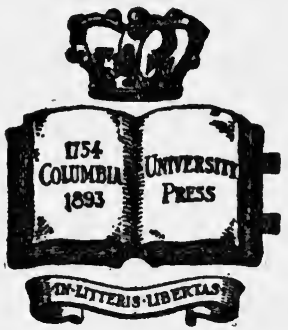

The Press was incorporated June 8,1893 , to promote the publication of the results of original research. It is a private corporation, related directly to Columbia University by the provisions that its Trustees shall be officers of the University and that the President of Columbia University shall be President of the Press.

The publications of the Columbia University Press include works on Biography, History, Economics, Education, Philosophy, Linguistics, and Literature, and the following series :

Columbia University Contributions to Anthropology.

Columbia University Biological Series.

Columbia Univeraity Studies in Cancer and Allied Subjects.

Columbia University Studies in Classical Philology.

Columbia University Studies in Comparative Literature.

Columbia University Studies in English.

Columbia University Geological Series.

Columbia University Germanic Studies.

Columbia University Indo-Iranian Series.

Columbia Unirersity Contributions to Oriental History and Philology.

Columbia University Oriental Studies.

Columbia Univeraity Studies in Romance Philology and Literature.

Adams Lectnres.

Julius Beer Lecturee.

Blumenthal Lectures.

Carpentier Lecturns.

Hewitt Lectures.

Jesup Lectures.

Catalogues will be sent free on application.

\section{Lemcke \& Buechner, Agents}




\section{COLUMBIA UNIVERSITY PRESS}

Columbia University in the City of New York

\section{COLUMBIA UNIVERSITY LECTURES}

\section{ADAMS LECTURES}

Graphical Methods. By Cari Runge, Ph.D., Professor of Applied Mathematics in the University of Göttingen; Kaiser Wilhelm Professor of German History and Institution for the year 1909-1910. 8vo, cloth, pp. ix+148. Price, $\$ 1.50$ net.

\section{JULIUS BEER LECTURES}

Social Evolution and Political Theory. By Leon 1 Rd T. HoBHouse, Professor of Sociology in the University of London. $12 \mathrm{mo}$, cloth, pp. ix +218 . Price, $\$ 1.50$ net.

\section{BLUMENTHAL LECTURES}

Political Problems of American Development. By ALBERT Shaw, LL.D., Editor of the Reviev of Reviews. 12mo, cloth, pp. vii +268 . Price, $\$ 1.50$ net.

Constitutional Government in the United States. By Woodrow WILsos, LL.D., Sometime President of Princeton University. $12 \mathrm{mo}$, cloth, pp. vii +236 . Price, $\$ 1.50$ net.

The Principles of Politics from the Viewpoint of the American Citizen. By Jereman W. Jenks, LL.D., Professor of Government and Public Administration in New York University. $12 \mathrm{mo}$, cloth, pp. xviii +187 . Price, $\$ 1.50$ net.

The Cost of Our National Government. By Henry Jones FoRD, Professor of Politics in Princeton University. $12 \mathrm{mo}$, cloth, pp. $x \nabla+147$. Price, $\$ 1.50$ net.

The Business of Congress. By Hon. Samuel W. MCCaLL, Member of Congress for Massachusetts. 12mo, cloth, pp. vii+ 215. Price, $\$ 1.50$ net.

Thomas Jefferson: His Permanent Influence on American Institutions. By Hon. John Sharp Williams, United States Senator from Mississippi. 12mo, cloth, pp. ix +330 . Price, $\$ 1.50$ net.

\section{LEMCKE \& BUECHNER, Agents}




\section{COLUMBIA UNIVERSITY PRESS}

Columbia University in the City of New York

\section{COLUMBIA UNIVERSITY LECTURES}

\section{CARPENTIER LECTURES}

The Nature and Sources of the Law. By JoHn ChIpMan GRAY, LL.D., Royall Professor of Law in Harvard University. $12 \mathrm{mo}$, cloth, pp. xii +332 . Price, $\$ 1.50$ net.

World Organization as Affected by the Nature of the Modern State. By Hon. DAvID JAYNe HILl, Sometime American Ambassador to Germany. 12mo, cloth, pp. ix +214. Price, $\$ 1.50$ net.

The Genius of the Common Law. By the Rr. How. Sir Frederick Pollock, Bart., D.C.L., LL. D., Bencher of Lincoln's Inn, Barrister-at-Law. 12mo, cloth, pp. vii+141. Price, $\$ 1.50$ net.

\section{HEWITT LECTURES}

The Problem of Monopoly. By Join Bates Clark, LL.D., Professor of Political Economy, Columbia University. 12mo, cloth, pp. vi +128 . Price, $\$ 1.50$ net.

Power. By Charles Edward Lucke, Ph.D., Professor of Mechanical Engineering, Columbia University. 12mo, cloth, pp. vii+316. Illustrated. Price, $\$ 2.00$ net.

The Doctrine of Evolution. Its Basis and its Scope. By Henry Edward Crampton, Ph.D., Professor of Zoology, Columbia University. 12mo, cloth, pp. ix +311 . Price, $\$ 1.50$ net.

Medieval Story and the Beginnings of the Social Ideals of English-Speaking People. By WILLIAM Witherle Lawrence, Ph.D., Associate Professor of English, Columbia University. 12mo, cloth, pp. xiv +236 . Price, $\$ 1.50$ net.

\section{JESUP LECTURES}

Light. By Richard C. Mactadrin, LL.D., Sc.D., President of the Massachusetts Institute of Technology. 12mo, cloth, pp. ix +251 . Portrait and figures. Price, $\$ 1.50$ net.

Scientific Features of Modern Medicine. By Frederic S. LeE, Ph.D., Dalton Professor of Physiology, Columbia University. $12 \mathrm{mo}$, cloth, pp. vii +183 . Price, $\$ 1.50$ net. 


\section{COLUMBIA UNIVERSITY PRESS}

Columbia University in the City of New York

\section{COLUMBIA UNIVERSITY LECTURES}

Four Stages of Greek Religion. By Gilbrrt Murrax, Regius Professor of Greek, in the University of Oxford. 8vo, cloth, pp. 223. Price, $\$ 1.50$ net.

Lectures on Science, Philosophy and Art. A series of twenty-one lectures descriptive in non-technical language of the achievements in Science, Philosophy and Art. 8vo, cloth. Price, $\$ 5.00$ net.

Lectures on Literature. A series of eighteen lectures by instructors of the University on literary art and on the great literatures of the world, ancient and modern. 8vo, cloth, pp. viii +404 . Price, $\$ 2.00$ net.

Greek Literature. A series of ten lectures delivered at Columbia University by scholars from various universities. 8vo, cloth, pp. vii+306. Price, $\$ 2.00$ net. The lectures are:

The Study of Greek Literature. By Paul Shorey, Ph.D., Professor of Greek, University of Chicago.

Epic Poetry. By Herbert Weir Smyth, Ph.D., Eliot Professor of Greek Literature, Harvard University.

Lyric Poetry. By Edward Delavan Perry, Ph.D., Jay Professor of Greek, Columbia University.

Tragedy. By James Rignall Wheeler, Ph.D., Professor of Greek Archæology and Art, Columbia University.

Comedy. By Edward Capps, Ph.D., Professor of Classics, Princeton University.

History. By Bernadotte Perrin, Ph.D., Lampson Professor of Greek Literature and History, Yale University.

Oratory. By Charles Forster Smith, Ph.D., Professor of Greek and Classical Philology, University of Wisconsin.

Philosophy. By Frederick J. E. Woodbridge, Ph.D., Johnsonian Professor of Philosophy, Columbia University.

Hellenistic Literature. By Henry W. Prescott, Ph.D., Professor of Classical Philology, University of Chicago.

Greek Influence on Roman Literature. By Gonzalezz LODGr, Ph.D., Professor of Latin and Greek, Columbia University.

\section{LEMCKE \& BUECHNER, Agents}



I 
UNIVERSITY OF CALIFORNI' 'IRN '

\author{
14 DAY USE
}

RETURN TO DESK FROM WHICH BORROWED

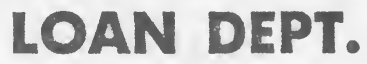

This book is due on the last date stamped below, or on the date to which renewed.

Regerved b8 8 shre subiect impediate recall.

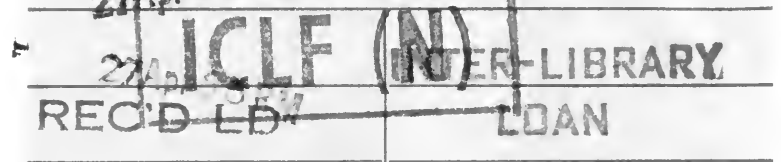

APR 27 '65-1: AM

DEG 790538 irecklerg

JAN / INTER-LIBRA

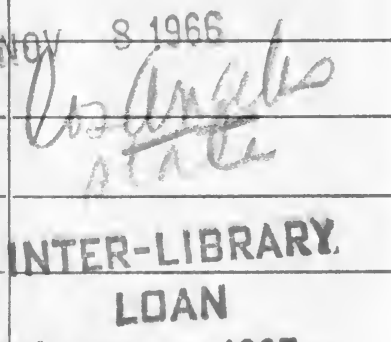

DEC $15^{\prime} 65^{-4} \pm$ PM SEP 271907

OCT 29196894

गCTसे 196092

ECEIVED

\begin{tabular}{c|c}
\hline JAN 14196652 \\
\hline REC'D & LOAN DEPT. \\
\hline DEC $29165-5$ PH \\
\hline
\end{tabular} 
U. C. BERKELEY LIBRARIES

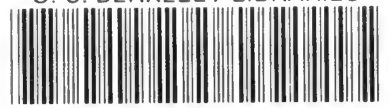

c061334729

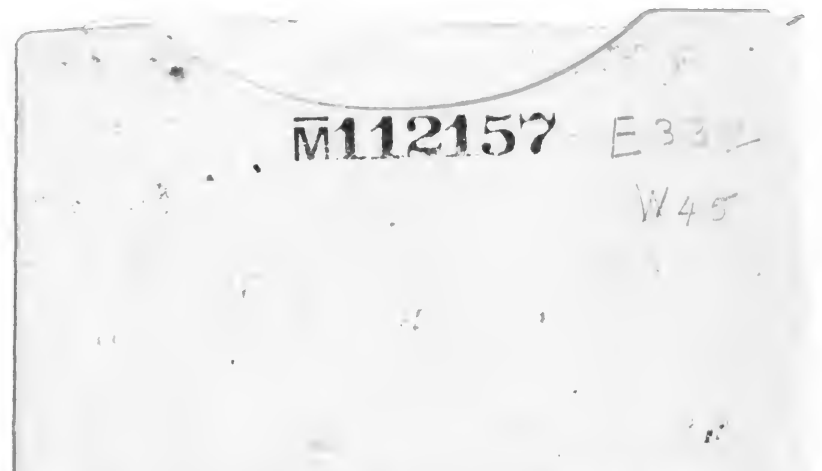

THE UNIVERSITY OF CALIFORNIA LIBRARY 
